UNIVERSIDADE DE SÃO PAULO

FACULDADE DE FILOSOFIA, LETRAS E CIÊNCIAS HUMANAS

DEPARTAMENTO DE ANTROPOLOGIA

PROGRAMA DE PÓS-GRADUAÇÃO EM ANTROPOLOGIA SOCIAL

\title{
Os Deni do Cuniuá: Um estudo do parentesco
}

Marcelo Pedro Florido

São Paulo

2013

Versão Corrigida 


\author{
UNIVERSIDADE DE SÃO PAULO \\ FACULDADE DE FILOSOFIA, LETRAS E CIÊNCIAS HUMANAS \\ DEPARTAMENTO DE ANTROPOLOGIA \\ PROGRAMA DE PÓS-GRADUAÇÃO EM ANTROPOLOGIA SOCIAL
}

\title{
Os Deni do Cuniuá: \\ Um estudo do parentesco
}

\begin{abstract}
Tese apresentada ao Programa de PósGraduação em Antropologia Social do Departamento de Antropologia da Faculdade de Filosofia, Letras e Ciências Humanas da Universidade de São Paulo, para a obtenção do título de Doutor em Antropologia Social.
\end{abstract}

Marcelo Pedro Florido

Orientador: Prof. Dr. Marcio Ferreira da Silva

São Paulo

2013

Versão Corrigida 


\section{Agradecimentos}

Devo tanto para tanta gente que minha memória não fará justiça de nomear todos nesses agradecimentos, seja porque recordo apenas dos apelidos maldosos, como daquele senhor que um dia me ajudou a atravessar um rio, ou somente dos rostos, como o do funcionário anônimo do recreio entre Tapauá e Manaus que salvou os cadernos de campo de uma chuva do inverno amazônico. São tantas coisas que acontecem pelo caminho e pela Amazônia que às vezes um dente de alho ou um pacote de café doado tem tanto valor quanto a série de injeções de antibióticos prescrita...

Agradeço à FAPESP que nos concedeu uma bolsa de doutorado e que financiou a pesquisa que resultou neste trabalho desde o mestrado.

Agradeço aos professores e funcionário do Departamento de Antropologia da USP por tudo que fizeram ao longo dos últimos 13 anos. Ao Marcio pela orientação e paciência durante meu mestrado e doutorado. A Marta Amoroso por ser minha orientadora na pesquisa científica quando ainda era um estudante de graduação e também pela participação do meu exame de qualificação. A Dominique pela participação na qualificação. Agradeço aos professores, pesquisadores e funcionários da UFAM e do NEAI pelas discussões estimulantes ao longo do processo de pesquisa, o Gilton, o Carlão...

Agradeço aos funcionários da FUNAI-Brasília, da CR Médio Purus, da Frente de Proteção Etno-ambietal pela ajuda, pelas caronas, pelas conversas pela radiofonia. Obrigado ao Luis, a Paulinha, ao Catuquina, ao Marcos, ao Amaral, ao Armando, ao Izac, ao Edilson, ao.... Aqui é um dos momentos em que a memória falha para nomear todos e aos que esqueci: desculpe-me. Agradeço a todos os técnicos de enfermagem e enfermeiros que passaram pela TI Deni durante nossa estadia (o Alberginio, a Vania, a Daniela, o Antônio, a....) e aos médicos que consultamos em Lábrea, Tapauá e Manaus. Aos funcionários da Fundação Vigilância em Saúde, que atuam no controle da malária. Ao Nando... Agradeço aos funcionários da secretaria municipal de educação do Tapauá, ao Eliomar, o Professor Val, o... A memória dos nomes pode falhar, mas os dias de convivência não foram esquecidos.

Agradeço ao Zé Bajaga, a Joabe, ao Marcelino, ao João Baiano e muitas outras pessoas do movimento indígena da região.

Agradeço ao pessoal do CIMI Manaus e do CIMI Lábrea pela ajuda na pesquisa, em especial a Adriana por ter nos apresentado os Deni. 
Agradeço aos moradores da Foz do Tapauá pelas refeições, conversas e outras coisas. Ao Antônio do bar pelos copos de água gelada, a tia do Geraldo e o Zé Mulher pelas refeições, ao João pelo guaraná... Um agradecimento especial para a Jomara...

Aos amigos e colegas da USP, da UFAM e da vida pelas contribuições diretas ou indiretas a este trabalho. A Milena pela colaboração fundamental para finalização deste trabalho. Ao Miguel pela leitura e comentário de partes da tese, bem como ao Lobão e a Fabiana pelo mesmo motivo. Ao Rafael por ter ajudado com o resumo em inglês. Ao Allan, Aline, Ana, Andre, Angelica, Antonio, Bianca, Ciça, Dassuen, Daniel, Edson, Fernando, Gambier, Giovanni, Guilherme, Igor, Ingrid, Isabela, José, Liliane, Luis, Marcel, Marcia, Milena, Neuzo, Neuzinho, Pedro, Rafael, Ricardo, Rodrigo, Rita Samantha, Uirá, Visão...

Há tantos mais a agradecer, mas não me lembro de seus nomes agora...

Um agradecimento especial a todos e cada um dos Deni por tudo que fizeram por mim.

Madihadeni. Tiadeni uvatikuruaru. Makhidehedeni, amunehedeni, ehevedeni uvatikharu. Tukhiraria uvatikuruaru. Hehe abunideni, Eraldo, Geraldo, Arivan, Mutha, Ukekeni, Tatazin, Tata, Taphavi, Irube, Paulo, Shiivi, Muthazin, Sharle, João Maia, Nura, Sivirivi, Erineu, Hama, Maranhão, Nemezumahi, Makhuveshi, Pusianu, Vaishuvi, Kashiberavi, Makakari, Bunarivi, Shikieteru, Leuvi, Biruruha, Zadari, Haku, Zahavi, Isaruha, Kapuheri, Kazupana, Zatina, Coronel, Banavi, Banu, Kakuva, Hazana, Purihari, Mavahari, Wilson (Tairivi), Zima, Tomoteio, Diivi, Hukuvi Zati, Tutui, Pizevi, Luru, Umanari. Abraão, Kapihava, Kenepetuvi, Zesido. Pharatarivi, Uzahi, Zezina, Aurivi, Mishira, Sururi, Hihi, Siivi, Makivi, Nazivi, Zezitu, Zezitu Zati. Hehe shuvideni, Uhinaha, Biruvi, Kazuza Ukezin. Hehe azudeni Zena, Benjamim, Shamunavi. Hehe abideni Hukuvi, Veri, Kakuva Zati. Hehe ami Bastiana. Hehe ukhavinideni, Ata, Paku, Maria Hita, Navirani, Caçula, Mara, Kava, Tabuhuni, Taphiuruni, Divani, Hakhiazani, Tiaharu, Nakusha, Tubeirini, Zaivini, Tamashuni, Vaani, Phaini, Kahiva, Bukuni, Kauruni, Amaniru, Rakitani, Viini, Peirini, Kunani, Tukiashani, Nikavaru, Kuhani, Zina, Kuzama, Tuirini, Tanuhu, Vanuza, Tuvani, Kumarna, Tumeuruni, Uharini, Abanuni, Napanani, Muvini, Kanika, Vanaha, Vaizu, Iedeni, Tavadira, Vaiarani, Alzira, Joaninha, Muvihana, Viashani, Manarina... 


\section{Índice}

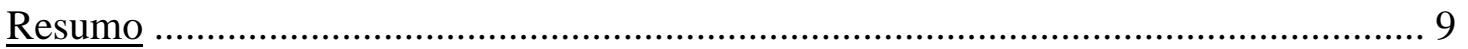

Introdução

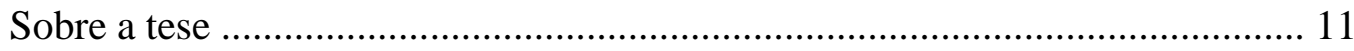

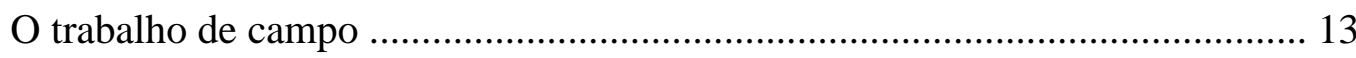

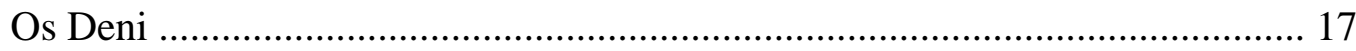

Capitulo 1 - Karivadeni. Os brancos no cosmos Deni .............................................. 27

1.1 - Narrativas, mitos e histórias ............................................................... 28

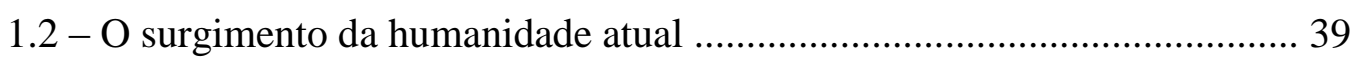

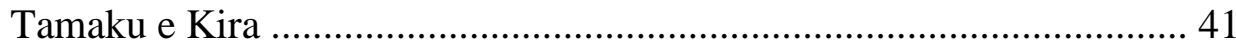

Tahama o primeiro kariva ................................................................. 57

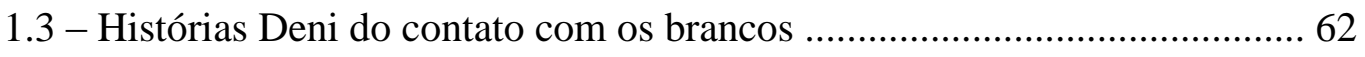

Manel Moco e Zé Alexandre ............................................................. 68

Os patrões do Cuniuá: da visita de Chico Severo ao

surgimento da TI Deni ................................................................... 73

Da demarcação às cidades ............................................................ 85

1.4 - Dos Kariva e seus poderes ............................................................. 92

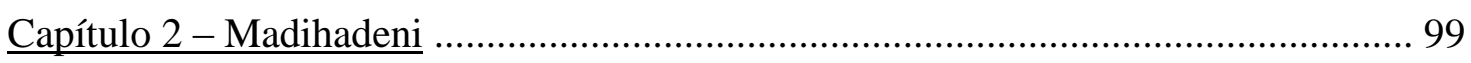

2.1 - O tempo da violência ....................................................................... 102

2.2 - A formação dos Deni e a pacificação ................................................... 117

2.3 - Os coletivos arawá .......................................................................... 132

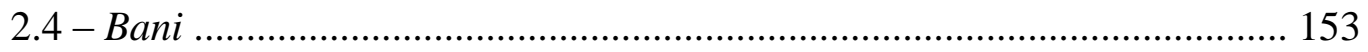

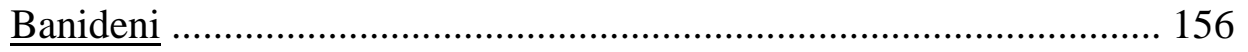

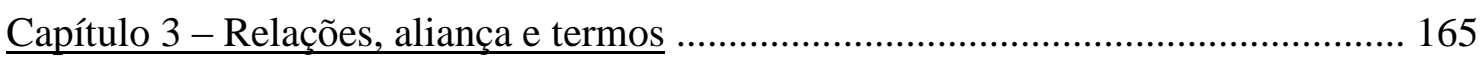

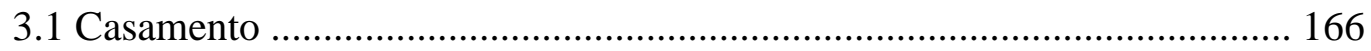

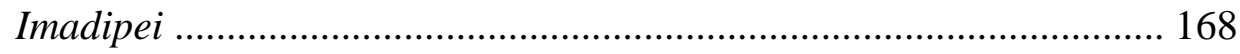

O cosmos, Нати e o problema do incesto ........................................ 171

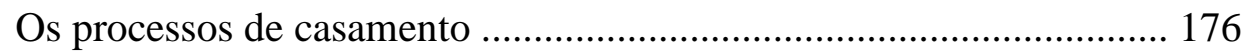

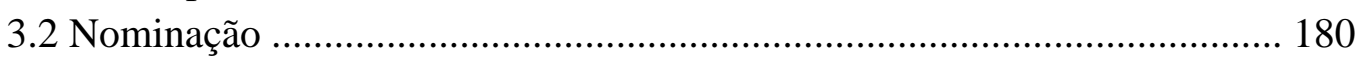

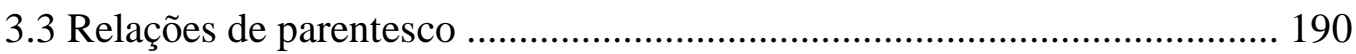

A terminologia de referência ............................................................. 193

Normas relacionais e atitudes ........................................................ 208

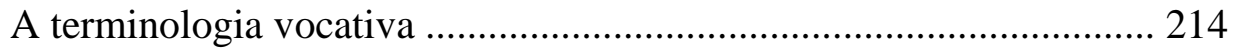

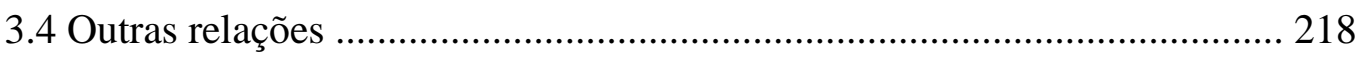

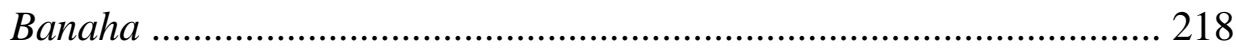

Ikatuviaride e itavari ............................................................ 220

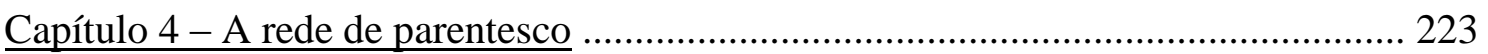

4.1 - A construção da genealogia Deni ...................................................... 225

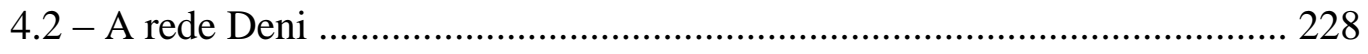


4.3 - Linhas masculinas

234

4.4 - Casamentos consanguíneos

249

Considerações finais

277

Bibliografia

281 


\section{Índice de imagens e tabelas}

\section{$\underline{\text { Mapas }}$}

Mapa 1 - Região do Médio Purus - Juruá ..................................................... 17

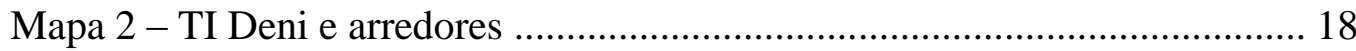

Mapa 3 - Populações indígenas do interflúvio Juruá - Purus ........................... 20

Mapa 4 - Localização aproximada das aldeias em 1999 e utilização de recursos .................................................................... 22

\section{Figuras}

Figura 1 - Família Arawá ......................................................................... 19

Figura 2 - Situação matrimonial inicial .................................................... 177

Figura 3 - Uniões matrimoniais desfeitas .................................................... 178

Figura 4 - Os casamentos após a reunião ………........................................ 178

Figura 5 - Terminologia de referência Deni Ego Masculino ......................... 195

Figura 6 - Terminologia de referência Deni Ego Feminino ........................... 195

Figura 7 - Esquema dravidiano modelo A ................................................... 201

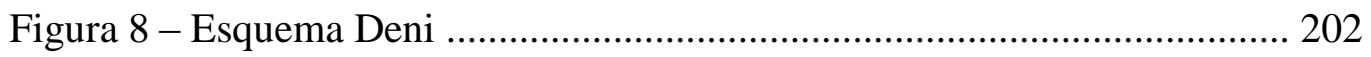

Figura 9 - Modelo classificatório ............................................................... 202

Figura 10 - Gradiente de proximidade e distância ......................................... 212

Figura 11 - Terminologia vocativa Deni para ego masculino ........................ 215

Figura 12 - Relações consanguíneas ........................................................... 231

Figura 13 - Relação de trocas entre as patrilinhas ....................................... 245

Figura 14 - Anel A1C1 ...................................................................... 248

Figura 15 - Classificação das sequências consanguíneas ............................... 258

Figura 16 - Frequência das sequências consanguíneas .................................. 261

Figura 17 - Ordem 1012 - 5 conexões ...................................................... 264

Figura 18 - A profundidade linear e a extensão colateral dos vínculos agnáticos ............................................................................. 270

Figura 19 - Casamentos da Ordem 3012 ................................................. 272

\section{$\underline{\text { Gráficos }}$}

Gráfico 1 - Relação entre memória de vínculos de filiação e profundidade geracional ........................................................... 232

Gráfico 2 - Relações matrimoniais entre as patrilinhas ............................... 239

Gráfico 3 - Trocas matrimoniais entre as maiorias patrilinhas ...................... 244

Gráfico 4 - Tipos de casamentos da rede ................................................... 251

\section{$\underline{\text { Tabelas }}$}

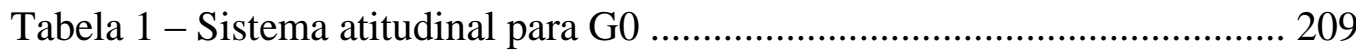

Tabela 2 - Sistema atitudinal para 3 gerações medianas ............................... 212

Tabela 3 - Distribuição das linhas agnáticas e uterinas ................................. 232 


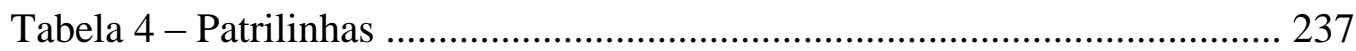

Tabela 5 - Quantidade de cônjuges por identidade e local ............................. 242

Tabela 6 - Os eventos matrimoniais entre as 5 maiores patrilinhas ............... 242

Tabela 7 - Casamentos e tipos de cruzamento ............................................... 254

Tabela 8 - Comprimento dos anéis ............................................................ 257

Tabela 9 - Frequência de repetição das ordens ............................................ 259

Tabela 10 - Ordem e cruzamento na geração de Ego e alternadas .................. 262

Tabela 11 - Ordem e cruzamento na $\mathrm{G}+1, \mathrm{G}-1$ e G -3 ................................ 262

Tabela 12 - Tamanho da conexão ............................................................... 263

Tabela 13 - Endogamia de linhas patri/matri .................................................. 264

Tabela 14 - Percursos cruzados 1013 ............................................................. 266

Tabela 15 - Percursos paralelos 1013 ............................................................... 266

Tabela 16 - Relação de sexo dos parentes de ligação ..................................... 267

Tabela 17 - Cruzamento em Alter para os pais de EGO ................................ 267

Tabela 18 - Ordem 3013 ........................................................................... 275

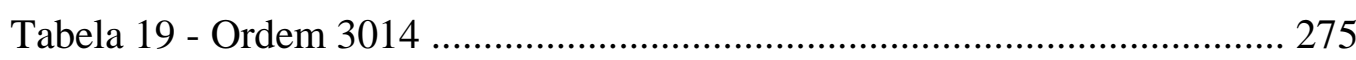




\title{
Resumo
}

Esta tese consiste na etnografia dos Deni do rio Cuniuá, localizados no sudoeste do estado do Amazonas e falantes de uma língua da família linguística arawá. Esta parte da população Deni vive em um relativo isolamento frente à sociedade brasileira, num cenário que contrasta com o intenso contato que mantinham algumas décadas atrás. A situação atual é antes o resultado de fatores histórico, como a crise do extrativismo e a demarcação das Terras Indígenas na região, do que do desejo dos próprios indígenas. A abordagem adotada coloca em primeiro plano o parentesco Deni, tomado como fio condutor e não como limite da análise. Abordando algumas temáticas da cosmologia deni, como a questão dos brancos, dos coletivos, da relação com os animais, da noção de pessoa, do casamento e dos vínculos de filiação, mostramos como o parentesco, longe de ser um domínio isolado, está relacionado com vários outros elementos do mundo. Realizamos aqui um exercício baseado em uma metodologia experimental para o estudo de genealogias, demonstrando como alguns aspectos do cosmos Deni influenciam suas práticas matrimoniais.

Palavras chaves: Deni - Parentesco - Cosmologia - Genealogia - Arawá

\begin{abstract}
This thesis is an ethnographic account of the Deni people, who live on the River Cuniuá at the Southwest corner of the Amazonas State and speak a language that belongs to the arawan family. This part of the Deni population currently lives in relative isolation from Brazilian society, which contrasts with the intense contacts of a few decades ago. The current situation is a direct result of historical factors such as the crisis of the extraction industry and the demarcation of native-land, and not the Deni's own desire. The approach adopted by the present work focuses on, but is not limited by, Deni kinship. It addresses some elements of Deni cosmology, such as their relations with the whites, the nominated groups, the animals, as well as their conception of personhood, marriage and filiation, and demonstrates the manner in which kinship relates to several other elements of the their world. The present work conducts an exercise based on an experimental methodology for studies of genealogy, thus demonstrating how some aspects of the Deni cosmos play an influence on their marriage practices
\end{abstract}

Keywords: Deni - Kinship - Cosmology - Genealogy - Arawan 


\section{Nota sobre a grafia dos termos na língua Deni}

Nossa grafia dos termos na língua Deni segue o que foi estabelecido pelo dicionário de Koop \& Koop (1985), com exceção da oclusão glotal que preferimos não grafar (como fazem os próprios Deni quando escrevem). Não há ditongos na língua deni, quando as vogais estão juntas, elas são pronunciadas separadamente. Apresentamos abaixo as letras do alfabeto Deni e uma palavra em português que possui o mesmo som. Nos casos em que o som não ocorre em português, ou quando é diferente, há uma explicação sobre a sua pronúncia.

Letra na língua Deni Som no Português

$\begin{array}{ll}\text { Vogais } & \\ \text { a } & \text { casa } \\ \text { e } & \text { pé } \\ \mathrm{i} & \text { vida } \\ \mathrm{u} & \text { puro }\end{array}$

\section{Consoantes}

b

d

$\mathrm{h}$

$\mathrm{m}$

$\mathrm{n}$

$\mathrm{k}$

$\mathrm{p}$

$\mathrm{s}$

$\mathrm{t}$

$\mathrm{kh}$

ph

sh

th

r

$\mathrm{V}$

Z boda (mas pronunciado com implosão de ar e, no meio da palavra, com uma oclusão glotal antes do som) rã (no dialeto carioca)

$$
\text { mato }
$$

ninho

copo

pai

tsé-tsé

terra

como os quatro sons acima, mas acompanhado por uma distinta aspiração.

orelha

ovo

como o inglês adze 'enxó' 


\section{Introdução}

\section{Sobre a tese}

Esta tese apresenta e descreve os sistemas de relações Deni, a partir da análise de algumas narrativas, e mostra como as práticas do parentesco estão relacionadas com outros elementos, tal como a memória, o pensamento sociológico, a noção de pessoa, etc... Tomamos o parentesco como parte da cosmologia, e não como um domínio autônomo da vida social, local em que se encontraria a forma de organização das sociedades sem Estado (Evans-Pritchard 1999 [1940]), ou principio irredutível de que depende a organização da vida social (Fortes 1949), ou qualquer outra posição que lhe atribui uma separação radical em relação a outros domínios da vida social. Não consideramos que ele seja um elemento central para o entendimento de uma cosmologia, ou um domínio analítico independente, mas, sim, que ele seja um local válido, a partir do qual é possível apreender aspectos da cosmologia Deni, tal como seriam o xamanismo, o ritual ou qualquer outro.

Esta tese corresponde a um exercício em que a lógica do que dizem é relacionada com aquela por trás do que fazem, isto é, levamos em consideração as aproximações que os Deni fizeram ao antropólogo (Lima 2005), durante nossa pesquisa de campo, e as relações resultantes da aplicação de algo que talvez seja indizível, mas que se reflete em uma determinada configuração das relações de filiação e aliança. Há, aqui, duas operações distintas em execuções, por um lado, há uma tentativa de traduzir as afirmações formuladas pelos Deni, sobre alguns aspectos do seu mundo, em palavras que as tornem inteligíveis para o leitor e, por outro, há a transformação de homens, mulheres e das relações de filiação e casamento em dados que fundamentam a construção e análise de uma rede genealógica. Não se trata, apenas, de considerar as definições nativas destes vínculos, de forma a tornar justificável a análise do constructo realizado pelo antropólogo, baseado na somatória das memórias, mas, sim, de levar em conta como estas relações se ligam com outras relações do universo Deni.

O parentesco é encarado como uma parte da cosmologia e não uma peça destacável, isto é, acreditamos que, a partir de qualquer lugar, podemos estabelecer uma conexão com ele. Dada esta possibilidade, partimos de outros locais que, a princípio, só tangenciam a temática do parentesco, mas, como mostraremos, possuem uma relação importante com ele. Este texto apresenta três momentos interligados, mas que possuem 
distintas motivações: um em que abordamos o que parece ser o tema de maior ${ }^{1}$ interesse para os Deni: os não-Deni; outro em que tecemos considerações a respeito dos subgrupos arawá, temática presente em quase todos os escritos etnográficos a respeito das populações da região e; por fim, abordamos o parentesco e algumas outras relações.

O capítulo 1 trata da questão dos não-indígenas, partindo de considerações a respeito dos regimes de historicidade Deni, da memória e história, e da relação do presente com os passados. Abordamos a questão das alteridades e da gênese das pessoas que povoam o mundo atual. É importante que o leitor atente para a questão de como as relações positivas com os Outros dependem do surgimento, constituição e instauração de uma diferença interna ao "Nós", a instauração do parentesco, ou seja, que as relações positivas com os Outros só podem surgir depois de existir o parentesco. Os não indígenas são construídos como o exterior e o limite do parentesco Deni, são, do ponto de vista ideal, o limite da endogamia, mas isto não se realiza na prática.

Através da consideração de algumas narrativas, levamos em conta, neste capítulo, como se dá a relação entre o presente e os diferentes passados, algo que, como veremos posteriormente, ganha expressão na terminologia de parentesco e na rede genealógica. A memória de eventos que estão relacionados aos vivos e mortos recentes, responsáveis por enunciar os acontecimentos que envolviam o "Nós", tem como emissor legítimo aqueles que já são avós, o que, no plano terminológico, resulta em um amalgama, do ponto de vista dos netos, do avó e seus ascendentes, tidos como detentores dos conhecimentos sobre o passado. A continuidade e descontinuidade temporal, bem como a separação entre um "Nós" e um "não-Nós", são elementos apresentados neste capítulo e permitem entender melhor a forma de construir entidades cósmicas que apresentamos no capítulo 2.

O capítulo 2 discorre sobre o pensamento sociológico Deni, abordando a questão dos subgrupos que, como veremos, não correspondem propriamente a conjuntos de pessoas, mas são composições que se formam a partir da relação com alguma forma de Outro, que causa a estabilização de um tipo de "Nós" indistinto internamente. O leitor deve ficar atento à equivalência (ou não diferença) que se estabelece entre as partes internas de uma destas identidades, pois elas correspondem a uma espécie de

\footnotetext{
${ }^{1}$ Este parece ser um dos temas mais comentados e debatidos atualmente, talvez em função da crescente presença dos Deni nas cidades e a melhora do seu acesso às mercadorias. Os outros assuntos bastante debatidos são o sexo (para os homens, dado o inconveniente das mulheres falarem de sexo na presença do antropólogo homem) e as caçadas.
} 
local a partir do qual se objetiva um ponto de vista e isto repercute no parentesco. No último capítulo, mostraremos como isto está infletido na genealogia (corresponderia a uma de suas distorções). Para demonstrar esses processos foi necessário considerar as relações que se estabelecem entre diferentes momentos de estabilização de uma perspectiva frente a uma alteridade, sendo o limite máximo a separação "humanos + quase humanos" e "animais" e o mínimo, até onde sabemos, a distinção interna da pessoa-corpo em uma multiplicidade de pessoa-almas.

O capítulo 3 apresenta o sistema de relações Deni, parte dele é dedicada àquelas comumente chamadas de relações de parentesco na tradição antropológica. Discutimos as noções relacionadas ao casamento, à fabricação do corpo, à nominação e à terminologia de parentesco, desvelando o modelo Deni a respeito dessas relações. O que se discute neste momento é fundamental para o entendimento do próximo capítulo e, embora não possamos levar em consideração todas as especificidades Deni na construção de sua genealogia, iremos mostrar como algumas características do parentesco Deni estão infletidas nas práticas do parentesco.

O capítulo 4 corresponde a um exercício experimental, no qual tentamos relacionar alguns elementos da sociocosmologia com a rede genealógica Deni, construída com base na somatória das memórias de algumas pessoas que dela participam. Apresentamos os resultados da utilização de algumas ferramentas computacionais para a análise de redes, tornando os padrões que surgem da decomposição da genealogia inteligíveis à luz das forças que atuam no cosmos Deni. Como utilizamos uma metodologia experimental, não pudemos apresentar muitas conclusões definitivas, então, finalizamos a tese explicitando algumas das relações encontradas.

\section{O trabalho de campo}

Nossa pesquisa contou com a realização de pouco mais de 16 meses de trabalho de campo, divididos em três etapas: entre maio e outubro de 2010; entre maio de 2011 e janeiro de 2012 e; entre maio e julho de 2012. A maior parte da pesquisa etnográfica ocorreu na aldeia Cidadezinha, primeira aldeia subindo o rio Cuniuá, pela qual passaram os moradores de outras localidades em diversos momentos. A instalação de telefones públicos em algumas aldeias do Cuniuá (Cidadezinha, Marrecão e Samauma) 
possibilitou que determinadas questões fossem exploradas através de telefonemas, mas, infelizmente, os mais velhos não o utilizam. Entramos em contato com a quase todos os moradores adultos e crianças das aldeias do Cuniuá, mas, não, com todos os velhos, principalmente os moradores de Samauma.

O primeiro contato com os Deni ocorreu no âmbito do movimento indígena, durante a assembleia em que foi refundada a organização indígena da região, a FOCIMP (Federação das Organizações e Comunidades Indígenas do Médio Purus), que congrega os indígenas de quatro municípios: Tapauá, Canutama, Lábrea e Pauini. Nesta oportunidade, conhecemos as lideranças de duas aldeias Deni, a da Cidadezinha e a do Marrecão, sendo que o líder dos primeiros argumentou que deveríamos seguir para sua comunidade, pois nunca um branco havia morado entre eles, diferente da Marrecão, na qual diversos missionários já haviam habitado. Nossa amizade duradora com esta liderança, que, como viemos a descobrir posteriormente, estava participando pela primeira vez do movimento indígena, e não era reconhecido como chefe por quase ninguém, colaborou para sua ascensão política, sendo, atualmente, reconhecida, tanto pelos Deni quanto pelos brancos e órgãos públicos, como chefe. Como veremos no capítulo 1 desta tese, os poderes do branco são valorizados, sendo que a obtenção de um branco de longe (o antropólogo), cujo trabalho esta liderança conseguia mobilizar (realizamos um censo para ele, depois ajudamos no processo de registro de RANI, civil, $\mathrm{RG}, \mathrm{CPF}$, bolsa família, etc..), colaborou para aumentar seu prestígio entre os demais.

Os primeiros momentos de contato com os Deni, aproveitando a presença da FUNAI na assembleia, foram dedicados à resolução dos trâmites burocráticos para obtermos a autorização para o ingresso na TI Deni. Isto acabou por gerar uma associação inicial entre o antropólogo e a FUNAI, o que era reforçado por estarmos querendo fazer uma "pesquisa", tal como Rodrigo Chaves (responsável pelo relatório de demarcação, conhecido entre os Deni como "filho da FUNAI") havia feito alguns anos atrás. Após a realização da primeira etapa de campo, nossa associação passou a ser com a figura dos missionários, já que, tal como eles faziam, morávamos na aldeia, tentávamos aprender a língua e possuíamos mercadorias inacessíveis nos tempos do extrativismo ou mesmo nas cidades da região que os Deni frequentam atualmente.

De qualquer maneira, os Deni associaram a atividade de pesquisa com uma espécie de trabalho, no qual que eu estava tentando adquirir alguns produtos (língua e histórias) que eles estavam acostumados a vender ao SIL e aos missionários. Muitos 
reclamavam que os missionários, após a prenderem a língua deni, pararam de ensinar o português, como reflexo disto, parte deles, evitou falar na língua nativa comigo durante muitos meses. Outros fizeram propostas comerciais para participarem da pesquisa, como cobrar $\mathrm{R} \$ 50$ por dia de aula da língua, trocar duas histórias por um gravador a pilhas, etc..

Aproximadamente 50 dias do período em campo foi gasto em viagens de barco, durante a quais era possível realizar discussões com muitas pessoas ao mesmo tempo, devido à proximidade (ou impossibilidade de fugirem do antropólogo). A maior parte destes deslocamentos ocorreu entre o rio Purus e a aldeia Cidadezinha, o que permitiu um grande conhecimento sobre os locais que possuíam algum significado especial, mas quase todos dizem respeito a lugares em que trabalharam, tendo sido o percurso do rio Cuniuá entre o Marrecão e a aldeia Samauma navegado apenas uma vez. Estes foram os momentos mais intensos de pesquisa, já que permitiram contatos prolongados com os aposentados de outras comunidades e o estabelecimento de dinâmicas em que estes e os moradores da Cidadezinha discutiam os eventos dos tempos passados, contribuindo com a construção de uma genealogia com grande profundidade temporal.

Pouco mais de cinco semanas de pesquisa foram realizadas nas cidades de Lábrea ( 8 dias divididos em três visitas), Tapauá (9 dias em dois momentos distintos) e na vila do Kamaruã - Foz do Tapauá (20 dias em duas oportunidades). As cidades eram os pontos a partir do qual se restabelecia e se interrompia o contato com os Deni, cujos barcos intercalam viagens mensais para Lábrea e Tapauá. Durante as estadias nas cidades, foi possível observar as formas como os Deni se relacionam com os não indígenas que não conhecem, com aqueles que já moraram próximos às aldeias e com os donos de loja com quem aposentados e professores deixam seus cartões de banco e mantêm dívidas ativas, pagas através do saque dos salários/benefícios. Estes eram momentos em que era quase impossível obter informações sobre a cultura Deni, mas eram os melhores para o aprendizado da língua, pois eles evitam, ao máximo, conversar em português entre si (mesmo quando falavam com o antropólogo).

Durante as estadias na Vila da Foz, foi possível entrar em contato com algumas pessoas que habitaram na região da TI Deni, entre as quais se inclui um dos filhos de Chico Severo, para quem a maior parte dos velhos da Cidadezinha trabalhou. Em 2011, numa dessas vezes em que ficamos na Foz do Tapauá, por, aproximadamente, 17 dias, estavam, também, a quase totalidade dos moradores da aldeia Viagem (apenas dois 
casais e seus filhos permaneceram na aldeia) e quase todos os adultos e jovens com filhos da aldeia Cidadezinha, que se deslocaram até lá para tirarem seus documentos durante a passagem da lancha PAI (Pronto Atendimento Itinerante) da SEAS - AM (Secretaria de Estado de Assistência Social). Após isto, os Deni passaram a ser assediados por alguns políticos do município de Tapauá, havendo planos de que um deles se candidate a vereador.

Em junho de 2011, tivemos a oportunidade de realizar uma viagem para todas as aldeias do Cuniuá. O objetivo dela era realizar o levantamento demográfico-censitário para uma das lideranças Deni, o que permitiu que entrássemos em contato com quase todos os velhos (exceto os da aldeia Samauma que estavam viajando) e fizéssemos o levantamento das relações de parentesco de pessoas já falecidas. Passamos ao menos 4 horas em cada uma das aldeias, realizando paradas mais prolongadas na aldeia Sikuriha, Viagem e Marrecão. Para esta última, realizamos um total de quatro viagens durante o trabalho de campo, com, aproximadamente, 10 dias de investigação sendo realizadas nela.

A maior parte da pesquisa ocorreu na aldeia Cidadezinha, onde dormíamos em um depósito de tábuas e telhado de palha que havia sido construído durante um dos projetos do CIMI. Este nosso posicionamento influenciou, de certa forma, a pesquisa, dado que nos tornamos mais próximos das pessoas que moravam nas proximidades. Isto não é trivial, pois os Deni relutam em fazer comentários acerca das próprias ideias para os não Deni, temendo, como pudemos observar na prática, que sejam ridicularizados.

Dada esta especificidade do contexto Deni, durante muito tempo, era necessário apresentar o que já havíamos descoberto sobre algum aspecto para ver se conseguíamos aprofundar a temática, ou seja, impedia que obtivéssemos informações variadas sobre certas coisas ${ }^{2}$. Com nossos vizinhos na aldeia, a situação acabou sendo superada após pouco tempo, talvez pelas trocas de informações a respeito do que eu sabia/acreditava sobre as mais variadas coisas possíveis. Muitos pediam para ouvir histórias dos brancos, outros queriam saber como era São Paulo (e após assistirem um vídeo disseram que era algo muito ruim), ou mesmo explicações sobre como um kariva (como chamam os

\footnotetext{
${ }^{2}$ No início da pesquisa, quando dizíamos alguma coisa, às vezes nos perguntavam quem tinha dito aquilo e após muito tempo descobrimos que isto acontecia, geralmente, quando a pessoa achava que haviam mentido para mim.
} 
brancos) tinha ido até a lua (um deles havia visto uma entrevista com Marcos Pontes na televisão durante uma estadia em Lábrea).

\section{Os Deni}

Os Deni se consideram, atualmente, como um conjunto diferenciado de outras populações indígenas e não indígenas pelo compartilhamento da língua. Eles são aproximadamente 1400 pessoas (Siasi/Sesai, 2012), sendo a língua deni bem conservada. Ela é falada pela totalidade da população ${ }^{3}$ e transmitida cotidianamente para as novas gerações. Os adultos apresentam certo grau de bilinguismo deni/português, sendo os homens melhores falantes que as mulheres e os mais velhos que os mais novos.

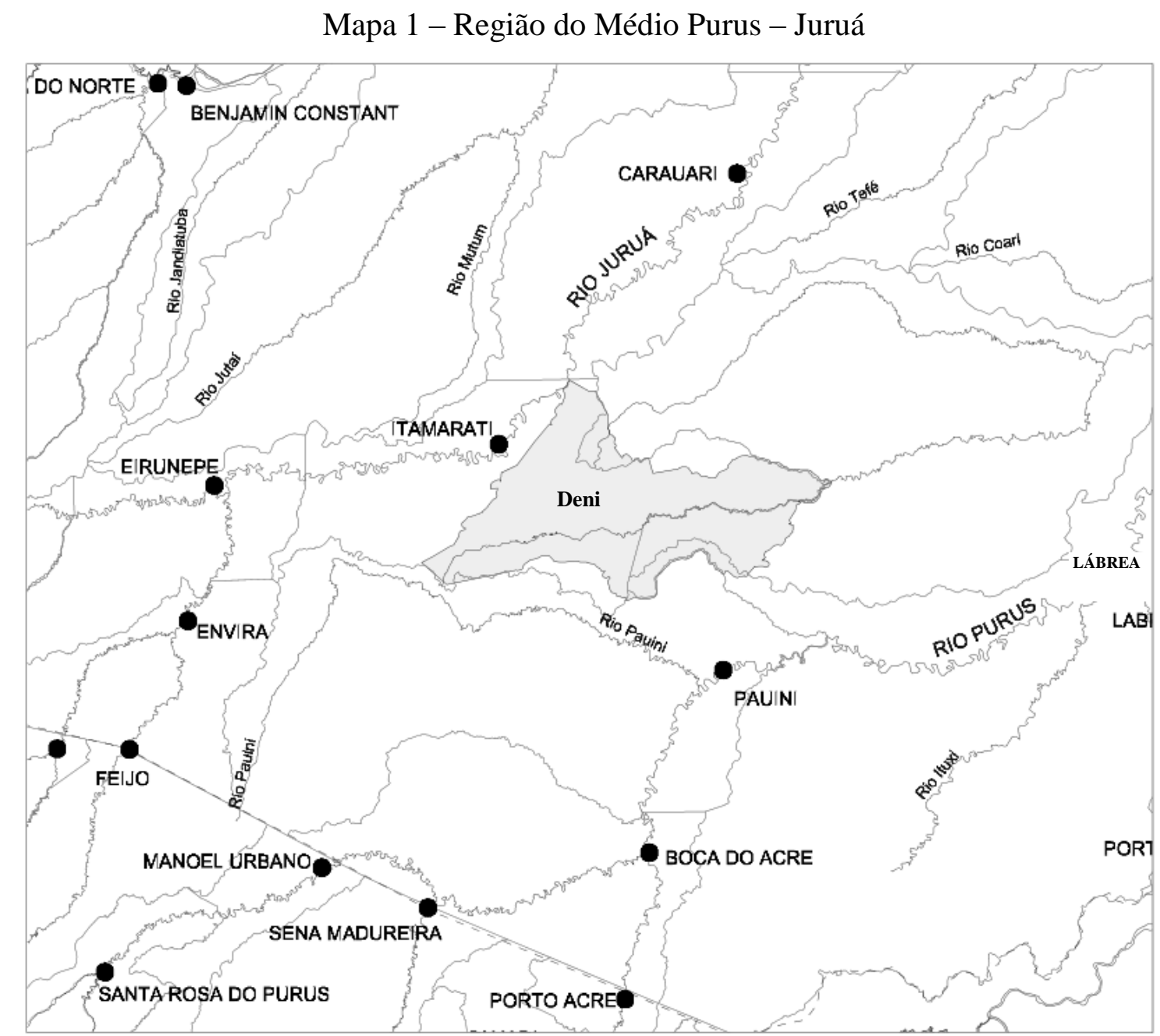

\footnotetext{
3 As informações linguísticas que comentamos agora são válidas para os habitantes do rio Cuniuá. Segundo estes o mesmo ocorreria no Xeruã, mas não pudemos confirmar as informações. Talvez no Xeruã, em função da maior proximidade com os não indígenas, haja mais crianças e mulheres bilíngues.
} 
A Terra Indígena (TI) Deni se localiza no sudoeste do estado do Amazonas, no interflúvio Juruá-Purus. A TI possui 1.531 .300 ha e se situa na "bacia hidrográfica do rio Solimões e é drenada por um afluente do Juruá, o Rio Xeruã, e pelo Canaçã e Cuniuá, afluentes do Tapauá, que por sua vez deságua no Purus" (Pezzuti \& Chaves 2009: 122). Enquanto que o rio Cuniuá tem sua origem dentro da área Deni, o que faz com quem não haja trafego de embarcações, o Xeruã a atravessa, sendo navegado tanto por indígenas quanto não indígenas. A área faz divisa com outras terras indígenas como é possível perceber no mapa abaixo.

Mapa 2 - TI Deni e arredores

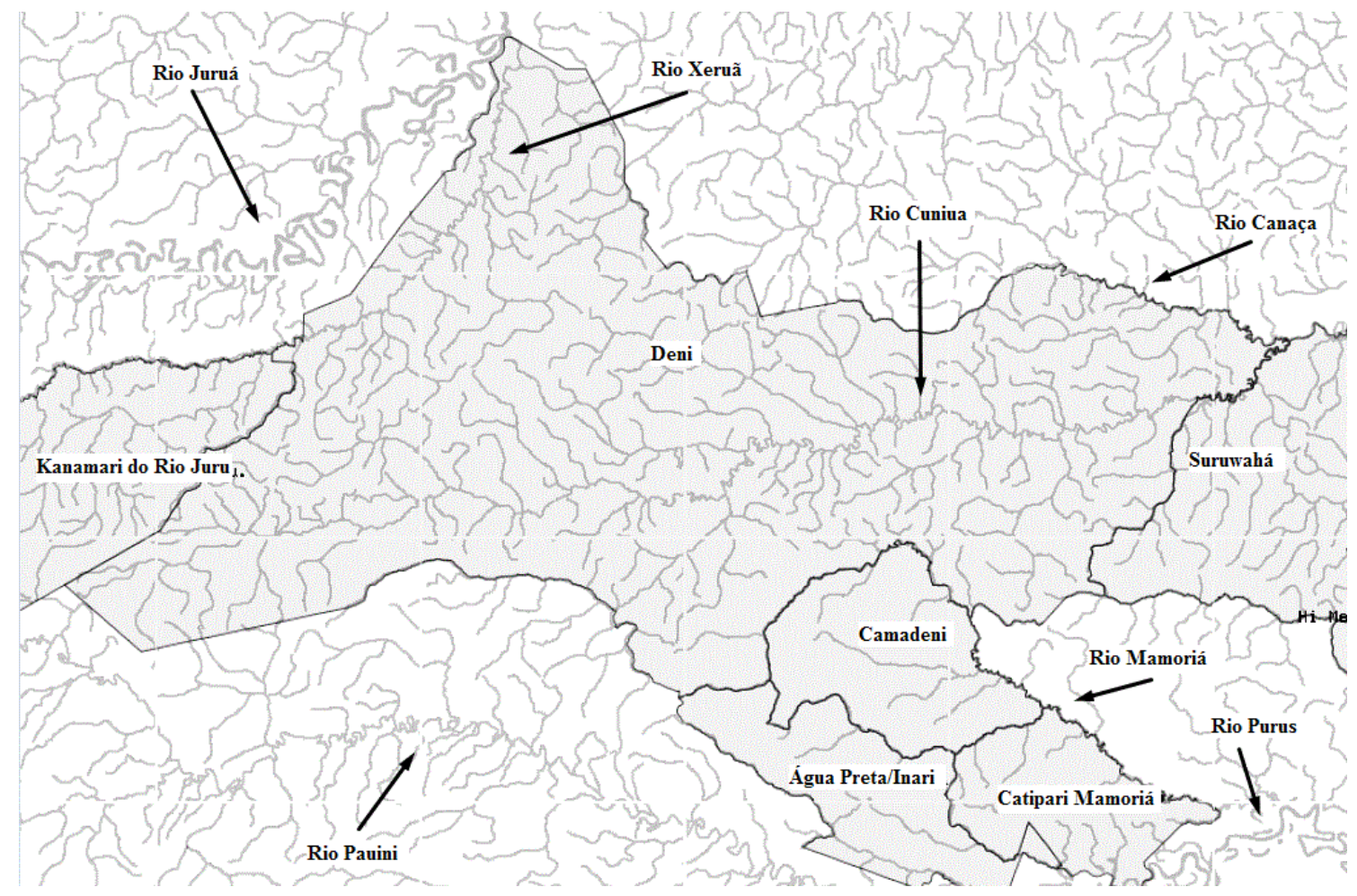

A língua deni, segundo a classificação mais recente realiza por Stefan Dienst (2008), faz parte da família linguística arawá, sendo uma língua mais próxima da kulina e daquela falada por alguns grupos identificados como Jamamadi do que das outras. Há dois conjuntos de línguas que são faladas por pessoas identificadas como Jamamadi, um que está localizado próximo à região dos Jarawara e outro que está situado acima da 
cidade de Pauini. A divisão da família pode ser visualizada no esquema abaixo que é fornecido por este autor.

Figura 1 - Família arawá

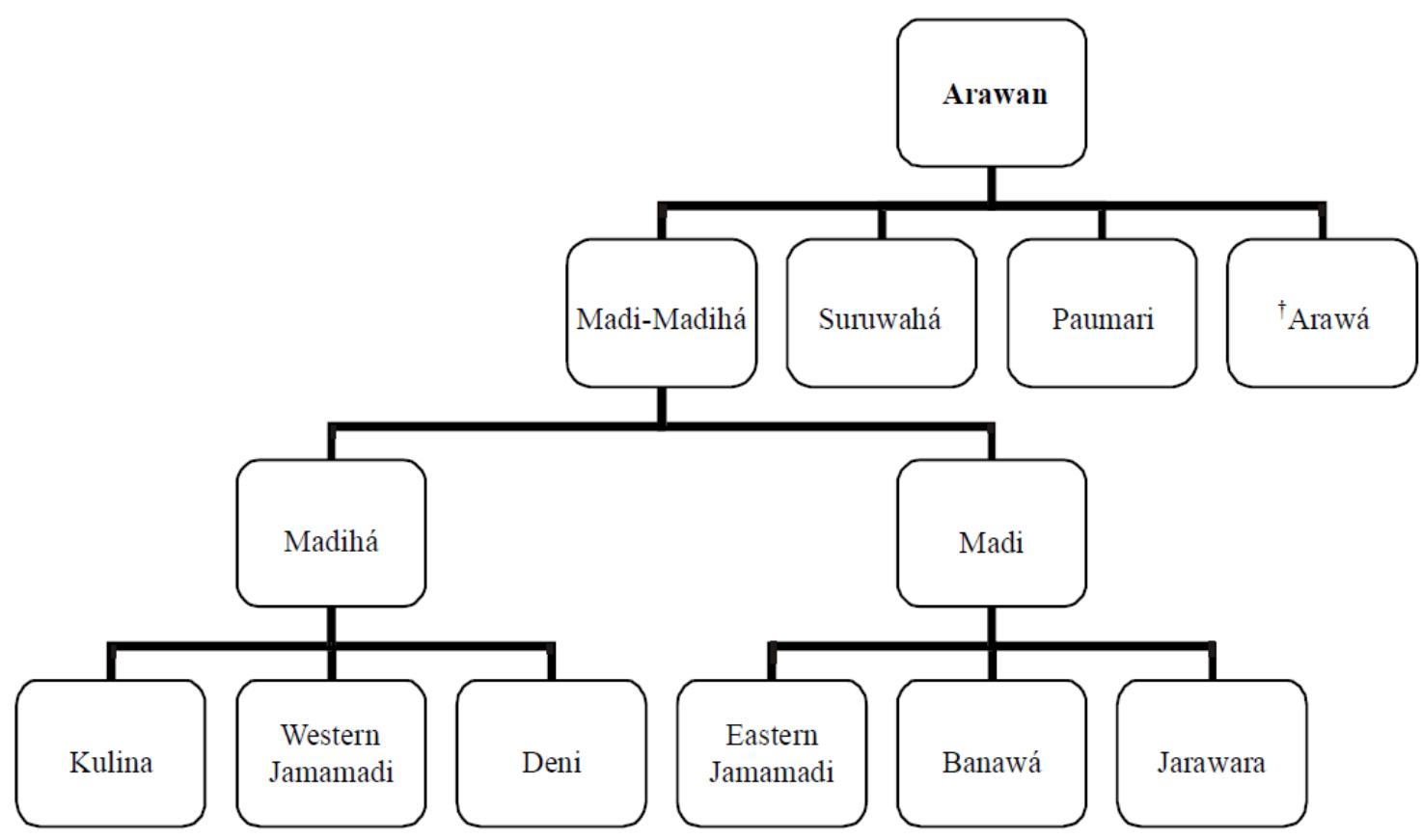

As populações falantes de línguas da família arawá estão restritas a região do Purus e Juruá. Nesta parte do Purus estão presentes também as línguas apurinã (família aruaque) e katukina (katukina) e do Juruá as kanamari e katukina (pano), incluídas em outras famílias linguísticas. Os Deni do Xeruã possuem contato permanente com os Kulina e os Kanamari, existindo alguns inter-casamentos, com famílias Kulina e homens Kanamari habitando nas aldeias Deni. Os Deni do Cuniuá tiveram alguns encontros com os Suruwahá durante suas expedições para extração de sorva, mas este foi interrompido. No âmbito do extrativismo, que teve sua decadência em meados da década de 1980, trabalharam junto com os Apurinã, Banawá e Jamamadi, atualmente mantendo contato com todas as populações que participam do movimento indígena do médio Purus nas reuniões da FOCIMP. 


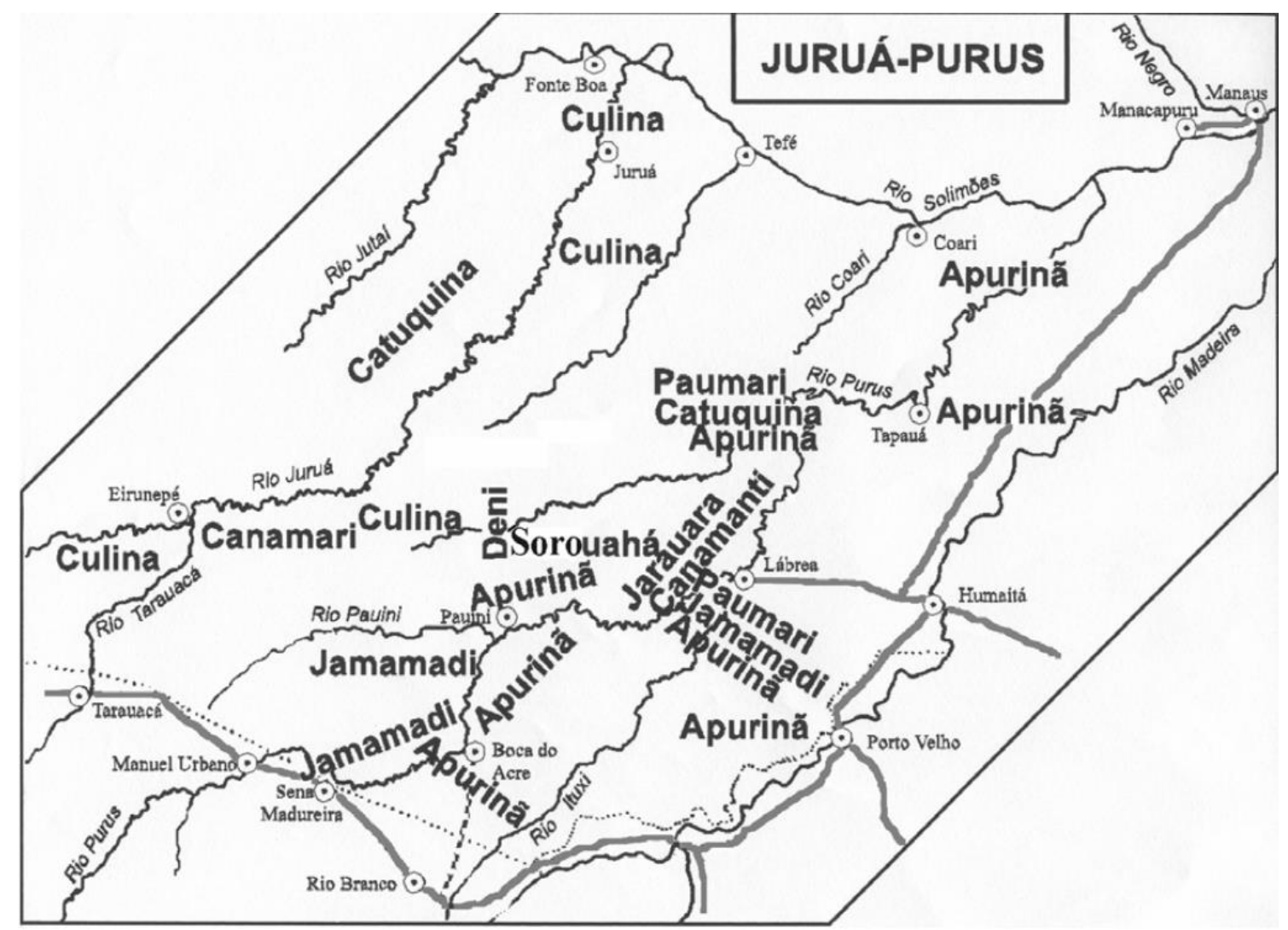

A população residente na TI Deni divide-se em dez aldeias, quatro localizadas na região do Xeruã e seis no Cuniuá. Não há ligação fluvial entre o Xeruã e o Cuniuá, sendo que as viagens entre eles são realizadas através de um caminho pela mata que parte de um igarapé do Cuniuá, localizado acima da aldeia Samauma, e atinge a aldeia Itaúba. Dispomos apenas de informações indiretas sobre as aldeias do Xeruã, obtidas a partir do Relatório de Demarcação de Chaves (2001), de uma publicação da ONG OPAN de 2011 a respeito do Plano de Manejo desenvolvido pelos Deni do Xeruã (Fanzeres s. d.) e de alguns Deni do Cuniuá que as visitaram ou que em décadas passadas foram co-residentes de seus fundadores.

O Deni do Xeruã e os do Cuniuá possuem dinâmica variadas de relação com a sociedade envolvente e as outras populações indígenas As aldeias do Xeruã (Itaúba, Terra Nova, Boiador e Morada Nova) mantêm contato quase constante com os não indígenas, os Kulina e Kanamari. Os Deni do Cuniuá vivem em um relativo isolamento, o contato com os não indígenas e outras populações ocorre, quase que exclusivamente,

\footnotetext{
${ }^{4}$ Disponível na Página do Melatti - http://www.juliomelatti.pro.br
} 
quanto eles visitam as cidades e vilas da região, o que demanda uma viagem de alguns dias pelo rio.

Esta situação atual do Cuniuá contrasta com aquele que ocorria 20 - 30 anos atrás, antes da crise da sorva, em meados da década de 1980, e da demarcação das terras indígenas na região, por volta do ano 2000, havia uma grande quantidade de colocações não indígenas no rio Cuniuá e seus afluentes. Nesse período de intenso contato, índios e brancos moravam nas mesmas localidades, ou se visitavam para participar das "festa" uns dos outros, jogavam futebol, dançavam forró, etc.. O afastamento dos não indígenas e de indígenas de outras populações da região do alto e médio Cuniuá resultou no isolamento atual, em que os não indígenas são encontrados, apenas, muito abaixo no rio Cuniuá, alguns dias de distância de barco do limite da TI.

Nos anos recentes, os moradores das aldeias que possuem barcos próprios (Samauma e Cidadezinha) passaram a frequentar periodicamente as cidades de Lábrea e Tapauá (as comunidades fariam parte deste último município), os moradores de outras comunidades viajam mais raramente. Em décadas passadas a região do rio que atualmente está dentro da TI era bastante trafegada por não indígenas, sendo que muitos não indígenas moravam no rio Cuniuá e seus afluentes, tanto acima quanto abaixo das localidades que passaram a ser habitadas pelos Deni. Alguns destes antigos moradores não indígenas estão nas cidades de Lábrea, Canutama, Tapauá e na vila do Kamaruã Foz do Tapauá, sendo visitados durante as viagens que os Deni realizam.

De modo geral, as aldeias Deni tendem, atualmente, a ter mais de 100 habitantes, algumas do Xeruã podendo, inclusive, já ter ultrapassado os 200. Há seis aldeias situadas nas proximidades do Cuniuá, a sequência delas, subindo o rio, é: Cidadezinha, Marrecão, Viagem/Zunamete, Volta Grande, Sikuriha e Samauma. Três delas possuem menos de 100 moradores, pois resultaram de uma fissão relativamente recente, motivada, segundo alguns, pela exclusão das famílias dos dissidentes dos cargos de professor e AIS e por brigas ligadas ao adultério para outros. A separação ocorreu a partir da aldeia Vi(s)agem ${ }^{5}$ Velha, a partir da qual se formaram: Viagem/Zunamete (os que ficaram na localidade original quando os outros saíram), Volta Grande e Sikuriha.

\footnotetext{
${ }^{5}$ A aldeia se chamava originalmente Visagem, que seria uma espécie de fantasma, assombração. Teve seu nome alterado por influencia de uma das equipes de saúde ligadas, na época, ao Distrito Sanitário Especial Indígena do Médio Purus, que atuou na região.
} 
Alguns dos moradores originais da aldeia Viagem também mudaram para o Samauma quando começaram a ocorrer as fissões.

Mapa $^{6} 4$ - Localização aproximada das aldeias em $1999^{7}$ e utilização de recursos

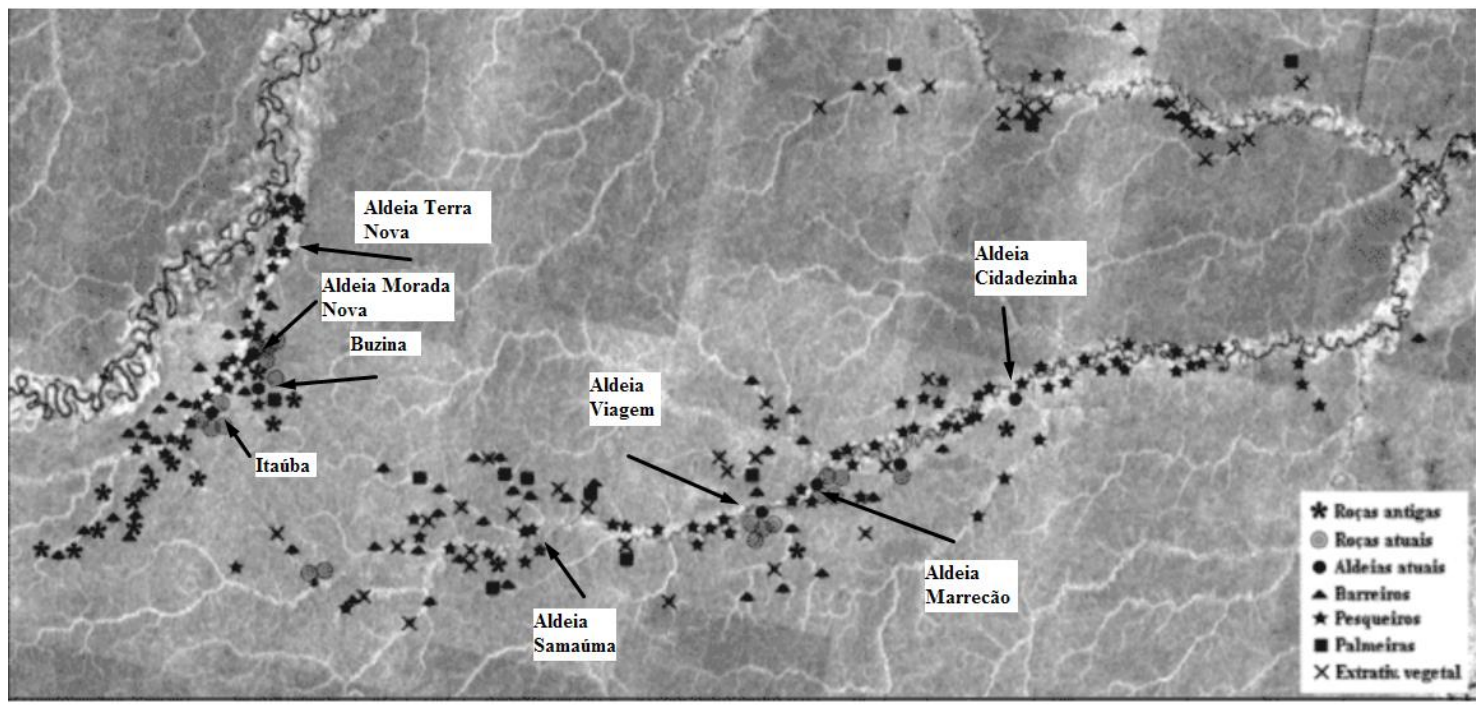

Figura 2 - Localização das aldeias atuais e antigas, roças, e locais de caça, pesca e coleta mapeados entre dezembro de 1998 e maio de 1999.

Todas as aldeias do Cuniuá compartilham algumas características gerais, sendo formadas por certo número de casas distribuídas em torno de um campo de futebol. Nas aldeias maiores, há residências que se situam por detrás daquelas que circulam o campo e, em alguns casos, existem casas mais afastadas das demais. As aldeias estão situadas em terrenos não alagáveis, mas que são relativamente ${ }^{8}$ próximos da margem do rio Cuniuá. Todas as casas são construídas no estilo regional, isto é, são palafitas de formato retangular, com telhado de duas aguas, sendo que algumas apresentam cozinhas construídas em separado, mas de forma contígua.

Todas as aldeias possuem uma configuração espacial mutável, com a disposição das casas sendo alterada ao longo dos meses. Durante um ano, alguns destroem suas casas antigas, constroem uma nova perto de algum parente, longe de outros, etc.

\footnotetext{
${ }^{6}$ Adaptado do mapa presente em Pezzuti \& Chaves (2009)

7 Após essa data a aldeia Viagem dividiu-se em três outras aldeias que se localizam acima da aldeia antiga, entre esta e a aldeia Samauma. As localizações são aproximadas, já que a aldeia Samauma nesta época ainda estava em um igarapé na terra firme, indicamos a sua localização aproximada na atualidade e não em 1999 ou quando primeiro chegou ao Cuniuá.

${ }^{8}$ A aldeia Cidadezinha fica em um barranco a margem do rio Cuniuá, as outras estão a alguns metros de distancia. Somente a aldeia Marrecão é um pouco mais afastada da margem, algo como 10 minutos de caminhada na época da seca, mas na cheia quase todo o caminho é alagado.
} 
Durante nossa estadia na Cidadezinha, apenas oito das 23 casas não mudaram de local. Informações obtidas por telefone indicaram que três destas foram transferidas para um novo local depois de julho de 2012. A área da aldeia não muda, as casas parecem se mover em uma determinada região circunscrita, indo para um lado que depois é abandonado e a mata volta a dominar, mas, após alguns anos, ele pode ser novamente limpo para a instalação de novas casas.

A composição das residências é variável, mas, após o casamento, os cônjuges vivem junto aos parentes da esposa, constituindo residências uxorilocais. Após ser formado o casal, todos habitam na casa dos pais da moça, configuração que perdura durante algum tempo, e, depois, eles constroem uma casa nova, vizinha a dos sogros do marido. Este arranjo, contudo, não perdura durante toda a vida do casal, pois, após alguns anos, o casal pode passar a habitar em um local distante dos parentes da mulher. Quando os pais do marido são lideranças, pode ser que o casal habite com eles desde o inicio. Nos casos em que um homem muito velho casa-se com uma mulher muito jovem, eles podem se estabelecer em qualquer lugar que desejarem, sem a necessidade de um período de uxorilocalidade.

$\mathrm{Na}$ prática, a composição das residências varia, havendo aquelas que são compostas por um casal, seus filhos solteiros e filhas casadas com os maridos e netos, outras em que o casal vive também com os filhos casados e netos e há muitas casas compostas por apenas um casal e seus filhos. A tendência geral é que os homens, após terem muitos filhos, morem próximos da mãe (o desejo de morar com os pais é formulado desta maneira) e dos irmãos homens, morando com os sogros durante apenas alguns anos após o casamento. A manutenção da configuração uxorilocal costuma ser mais frequente quando a esposa é significativamente mais velha que o marido, algo que não é incomum, havendo mulheres que são 10-20 anos mais velhas que os maridos.

As aldeias Deni do Cuniuá contrastam com as de outras populações indígenas da região do Purus, cuja população não chega a 100 habitantes (segundo dados da secretaria de educação do município do Tapauá, somente as aldeias Deni chegam em 100 habitantes). Três das aldeias do Cuniuá possuem mais de 100 moradores: Cidadezinha, Marrecão e Samaúma. As outras três, que ainda não atingiram esta marca, correspondem a fissões a partir de uma aldeia original, resultando em aldeias que se somadas, ultrapassariam também esta marca. Esta fissão é um evento que difere da tendência à fusões dos anos recentes, pois, mesmo quando há fissões, elas são, 
comumente, seguidas por fusões em comunidades já estabelecidas. Isto fica evidente ao considerarmos o desenvolvimento da aldeia Cidadezinha.

A aldeia Cidadezinha foi fundada "por volta de 1989" (Chaves 2001: 23), por dois irmãos que, pouco após os primeiros contatos no Cuniuá com os não indígenas, quando ainda eram jovens, passaram a morar em meio aos não-Deni e trabalhar para Chico Severo. Um deles iniciou um roçado no local para onde se mudaram posteriormente, um dos cunhados também foi para a localidade próximo a data de sua fundação. Posteriormente, outros irmãos destas pessoas, originários em grande parte da aldeia Marrecão Velho, passaram a habitar na localidade, cuja população atual, em sua maioria, descende deste grupo de siblings.

Algumas outras famílias da aldeia Marrecão, também, mudaram para a Cidadezinha em época recuada, sendo que muitos moradores da Cidadezinha apontam que só possuem "parentes verdadeiros" no Marrecão. A última grande família a mudar para a comunidade foi um casal de velhos e seus filhos (alguns casados) que haviam morado anteriormente na aldeia Viagem, onde estavam desde sua fundação, migrando uns 10-11 anos atrás para a Cidadezinha. Vemos, aqui, claramente, que são fissões de outras comunidades que se fundem na Cidadezinha, onde passam a habitar.

O mesmo processo de fusão pode ser visto na criação da aldeia Marrecão. Ela foi originada da fusão de duas migrações ${ }^{9}$ oriundas de uma das aldeias localizadas no alto Cuniuá que estabeleceram, em momentos distintos, moradias próximas à região do igarapé Marrecão Grande, em lados opostos do rio Cuniuá. A primeira delas se estabeleceu junto à Adriano Lopes, para quem alguns trabalhavam desde antes de se mudarem. A segunda se estabeleceu na margem oposta, no curso do igarapé Marrecão e, embora o SIL (Summer Institute of Linguistic) já atuasse entre os Deni nas aldeias do alto Cuniuá desde 1965 (Koop \& Lingenfelter 1983), eles escolheram este novo assentamento para continuar a desenvolver suas pesquisas. A relação com os patrões (patarahu na língua Deni) do SIL, generosos nos pagamentos que faziam quando

\footnotetext{
${ }^{9}$ Este é o ponto de vista dos próprios Deni. Segundo eles algumas pessoas saíram da aldeia no alto Cuniuá e se estabeleceram junto a Adriano Lopes. Em data posterior houve a mudança de outras pessoas da aldeia original que se estabeleceram na margem oposta do Cuniuá. Na percepção deles houve uma fissão que originou duas aldeias distintas, mesmo que ambas tenham se aproximado de Adriano Lopes. Posteriormente ocorreu a fusão das duas comunidades, influenciada pela opção dos funcionários do SIL de trabalharem naquela que estava mais afastada dos não indígenas. A atração da aldeia mais antiga ocorreu em função do "pagamento, em mercadoria, pelo trabalho na pista de pouso" (Koop \& Lingenfelter 1983: 5).
} 
estavam comprando ${ }^{10}$ a língua deni, fez com que ocorresse a fusão dos dois grupos. Posteriormente, uma parte desta aldeia original foi morar na Cidadezinha.

A fusão que resulta nas aldeias atuais não é, somente, a agregação de pessoas que saem de uma aldeia e se dirigem, diretamente, para outra. Vemos na composição da aldeia Cidadezinha, que quase todos os homens velhos da aldeia habitaram junto aos não indígenas durante parte de suas vidas, alguns trabalharam em barcos, nos quais passavam muitos meses, alguns mais de um ano, tendo realizado viagens para Manaus, Santarém, um deles conheceu até mesmo o Peru. Ocorreram algumas fissões ao longo da história Deni, que resultaram em pessoas, casais, em alguns casos famílias inteiras, que viveram isolados ou em meio aos brancos, antes de se fundirem novamente em alguma aldeia.

Há dois processos de composição de aldeias atuantes atualmente, em um deles, partes de uma aldeia migram direto para outra; e, no outro, há um isolamento momentâneo, seguido por uma fusão ou por um retorno a aldeia original. O processo de migração pode ser visto atualmente em ação, como fica claro a partir de um evento ocorrido em 2011 que ilustra o processo. Uma família da aldeia Viagem resolveu se mudar para a aldeia Cidadezinha, essa migração envolveu um casal com muitos filhos, a mãe da esposa, dois genros e netos, num total de 13 pessoas. Uma das filhas do casal, que habitava com a família do marido em Samauma, também foi para a Cidadezinha, junto com o marido e seus filhos, mas retornou para o Samauma logo após terem construído uma casa na Cidadezinha. O casal que havia migrado, por sua vez, retornou para a aldeia Viagem, mas mantém as casas construídas e um roçado plantado na Cidadezinha.

Não são poucos os casos de pessoas que habitam (possuem casas) em mais de um local, seja um roçado no qual existe um conjunto de casas, ou outra aldeia. Muitos desses casos correspondem ao processo de isolamento momentâneo, pelo qual algumas famílias passam, durante algum tempo, ao longo dos anos. Algumas pessoas plantam um roçado em uma localidade afastada, algumas horas ou mais de um dia, da aldeia em que habitam. Muitas famílias passam parte do ano nestas localidades afastadas, mas todos mantêm residências em determinada aldeia que identificam como sua residência.

\footnotetext{
${ }^{10}$ Os Deni concebem que sua língua e histórias são um produto, tal como a copaíba, a farinha, o peixe, etc., que pode ser vendida. Os missionários, categoria em que incluem as pessoas do SIL, são os maiores consumidores destes produtos.
} 
Essa identificação como morador de uma aldeia é algo que perdura, já que as aldeias se movimentam em conjunto, carregando o nome da aldeia. A aldeia Marrecão, por exemplo, possui uma localização atual que não é a mesma de quando seus ancestrais se fundiram, mas a migração carregou consigo todos os moradores e o nome original. Ela aparenta ser a aldeia mais fragmentada de todas, pois algumas casas estão afastadas das demais. Algumas residências ficam em torno do campo de futebol, outras estão próximas à pista de pouso, outras são acessíveis por caminhos não muito distantes, mas a floresta entre elas encobre a visão. Esta aparente pulverização das moradias não impede, contudo, que eles se considerem como uma comunidade.

Durante a maior parte do ano, é difícil encontrar, em uma aldeia Deni, todas as pessoas que se identificam como seus moradores. Além dessas casas no roçado, as viagens de barco às cidades mantêm uma parte considerável dos moradores afastados da aldeia. Se, antes, eram grandes caçadas coletivas que mantinham partes da população afastada, nas décadas passadas era a atividade extrativista e, agora, são viagens para a cidade e casas de roçado que mantêm as pessoas afastadas das aldeias, que, em muitos momentos, parecem existir, apenas, pela influência do convívio com os não indígenas, pois é nelas, por exemplo, que o atendimento a saúde acontece.

Esta vivência com os brancos teve muitas consequências, entre elas a incorporação de números, pesos e medidas do português no vocabulário deni; o desenvolvimento de ideias acerca do trabalho (para os brancos) enquanto um valor (que não se faz presente nas gerações mais novas que se furtam a exploração) e a incorporação do futebol e do forró. O forró e o futebol acabaram por se tornar elementos centrais da vida ritual em todas as aldeias Deni do Cuniuá (possivelmente também do Xeruã), sendo que os gravadores, ligados em baterias, pois não há motor de luz, tocam quase diariamente. O futebol é, atualmente, o principal responsável pelas visitas entre aldeias, ocorrendo vários "torneios" durante o ano, principalmente na época da seca. 


\section{Capitulo 1 - Karivadeni. Os brancos no cosmos Deni}

Seria impossível abordar a sociocosmologia Deni sem levar em consideração o lugar que os não indígenas ocupam. Vamos considerar, aqui, como eles se apresentam no pensamento Deni antes de considerar como influenciaram as transformações cosmológicas e sociais. Sua presença não é vista como causadora de perdas nas formações socioculturais anteriores, que teriam "invalidado o sistema econômico" e levado à desestruturação da "organização autônoma e [...] unicidade étnica e cultural" (Kroemer 1985:150) como foi apontado para as populações indígenas da região do Purus. O kariva, suas ações, suas mercadorias, patógenos e remédios, vão ocupar uma posição como se nunca tivessem faltado no sistema.

Kariva é uma categoria ampla e com diferentes alcances, aplicável aos não indígenas, sendo kariva.deni a forma plural. Ela corresponde, por um lado, aos brasileiros, protótipos dos kariva, mas, por outro lado, ela é estendida para os falantes do espanhol, que seriam os kariva de fala ruim. Falantes de outros idiomas não indígenas, como pessoas ligadas aos funcionários do SIL, com quem tiveram contato na segunda metade do século XX, parte dos missionários e dos membros do Greenpeace, que os Deni conheceram durante uma campanha em favor da demarcação da TI Deni no inicio do século XXI, são amerikanu, diferenciados dos kariva, mas que são kariva quando são contrapostos aos indígenas (madi).

A relevância dos não indígenas nas cosmologias da região não se limita aos Deni, sendo evidente em muitas populações, tal como os Paumari ${ }^{11}$ (Bonilla 2005a, 2007). Entre estes, as relações estabelecidas no âmbito do sistema de aviamento, que remontam ao século XIX, foram tomadas como a forma prototípicas da Relação. O

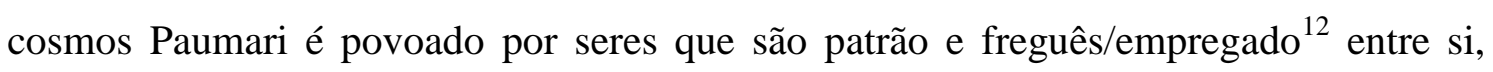
existindo um esforço dos humanos em comercializar todas as suas relações com a alteridade e tornarem-se, assim, empregados dos Outros.

\footnotetext{
${ }^{11}$ Poderíamos mencionar também os Suruwahá que assumem, nas relações interétnicas, o nome de um de seus Outros. Suruwahá era um dos grupos existentes nas narrativas dos tempos passados, sem descendentes vivos na atualidade. Os Suruwahá de hoje assumiram a identidade dos outros que estavam em contato permanente com os brancos (Aparício 2013), aplicando essa autodenominação não apenas quando falam com os brancos mas também com outros indígenas; isto é, o quem somos nós para os Outros, corresponderia a somos os que vivem com os brancos e se valem das potencias associadas a eles.

${ }^{12}$ Segundo a autora há uma diferença entre essas posições. O freguês tem relações mais esporádicas com o patrão, já o tornar-se empregado coloca os termos em uma relação permanente, ficando os empregados sob a proteção do patrão.
} 
Embora os Deni não tomem a relação patrão-empregado como estando reproduzida em todo o cosmos, os não indígenas, e mesmo a figura do patrão, possuem grande relevância sociocosmologia, seja nos domínios rituais, celestes, musicais, políticos, das trocas, da vida cotidiana, etc.. Poderíamos abordar apenas esta questão e uma tese não seria suficiente, apresentaremos, portanto, alguns em que a presença dos não indígenas é relevante para a sociologia Deni. Começaremos, tal como frequentemente fazem aqueles que os Deni consideram como conhecedores das suas histórias, por apresentar uma narrativa sobre o surgimento da humanidade atual, na qual alguns situam o surgimento dos não indígenas. Depois vamos considerar os relatos acerca do surgimento dos brancos no mundo, considerando as narrativas que a isto se detém e os discursos sobre seu aparecimento na região. Serão utilizados a memória dos próprios indígenas, alguns registros documentais e relatos registrados por Kroemer (1997). Passaremos depois às relações estabelecidas no âmbito das cidades.

\section{1 - Narrativas, mitos e histórias}

No contexto Deni há grande variação na distribuição das narrativas, sendo que a vida de uma pessoa, os encontros que teve e os locais que visitou ou morou influenciam o seu conhecimento sobre determinadas narrativas. Não há, como Sáez (2006: 318) afirma para os Yaminawa do Acre, uma homogeneidade no estoque de narrativas associada a acentuação da heterogeneidade interna. Os Deni, ao contrário, não procuram acentuar suas diferenças internas, mas são marcados por uma multiplicidade dos discursos, mesmo que, curiosamente, alguns dentre eles possam ser tomados como "variações jề ${ }^{13 \text { " }}$ (Lévi-Strauss 2004 [1964]) de mitos Yaminawa fornecidos por Sáez (2006).

\footnotetext{
${ }^{13}$ Muitos dos mitos Yaminawa possuem versões em Deni, que podem ser tomadas como variações uns dos outros. Por exemplo, a narrativa Awi Pide dos Yaminawa fornecida por Sáez (M23 2006: 416-418) que possui uma versão muito semelhante entre os Deni. As sequências são: Jaminawa(J) - um homem resolveu comer a esposa, Deni (D) - um homem resolveu comer a esposa. (J) Marido vai buscar lenha e depois peixe bodó enquanto a esposa fica descansando. (D) Marido vai buscar lenha enquanto esposa fica pegando peixe tamuatá. (J) Marido mata e come a mulher e seus três filhos. (D) O marido mata e come a esposa, casa com as irmãs da esposa e também as come. (J) Marido atrai sua segunda esposa para o mesmo local, mas ela acha os ossos dentro de um paneiro no igarapé e se esconde atrás de uma árvore. (D) O marido casa com a última irmã (caçula), ela encontra os ossos dentro da água e sobe em uma árvore para se esconder. (J) $\mathrm{O}$ homem resolve comer uma parte do próprio corpo, mas ao acertar o tendão cai imobilizado e é morto pela mulher. (D) $\mathrm{O}$ homem resolve comer partes do próprio corpo, até que corta o próprio coração e morre.
} 
Há, entre os Deni, um número muito restrito de histórias amplamente conhecidas e muitas outras que possuem distribuição variável, conhecidas em alguns locais ou por algumas famílias, mas não por outras. Há uma compilação de mitos Deni do Xeruã (Sass 2004), feita por um missionário, que circulou no Cuniuá e isto levou algumas pessoas alfabetizadas a se familiarizarem com essas histórias, mas outras desconhecem boa parte delas. Não são apenas versões de mitos ligadas a determinadas famílias, mas enunciados de eventos diferentes, cujo conhecimento é restringido pela cadeia de transmissão que cada pessoa acessou ao longo de sua vida.

Durante nossa pesquisa de campo, identificamos alguns "tipos de narrativa" (Franchetto 2003) concebidos pelos Deni. Ima é o termo que recobre o conteúdo da comunicação oral ordinária, podendo ser entendido como a fala, a narrativa, a conversa, o discurso ou o enunciado enquanto um texto. Até onde sabemos, diferente da fala ordinária existem três tipos nomeados: os imabute, ima ukide e mishe. Devemos considerar que os diferentes tipos de fala representam diferenças que vão além do conteúdo. Não caberia aqui considerar de forma pormenorizada todos esses tipos que apresentaremos resumidamente, pois, só iremos nos deter, nesta tese, nos imabute e em alguns ima.

Ima ukide são narrativas sobre eventos que poderiam ter ocorrido e são contadas com o propósito de alegrar os ouvintes, são espécies de piadas. Elas surgem comumente quando estão reunidas pessoas de um único gênero, abordando quase sempre as desventuras de alguém que narra na primeira pessoa. $\mathrm{O}$ termo $u k i$ corresponde à gordura/óleo, elemento responsável pelo sabor agradável de alguns alimentos, e o afixo _de torna uki um adjetivo, assim ima ukide seria algo como "conversa saborosa".

Os mishe são os cantos. Eles são divididos entre aqueles em que se conhece a autoria (mishe simplesmente) e aqueles em que ela é desconhecida, o que ocorre devido a sua origem antiga (mishe hurasha). Há, também, uma divisão entre os que incorporam palavras do português (mishe biriharu) e os que não incorporam (mishe putaharu). Eles ocorrem, quase que invariavelmente, no contexto de rituais e festas tradicionais, porém, no cotidiano, não é incomum uma mãe cantar para seus filhos pequenos.

Identificamos, também, dois outros tipos de enunciação não nomeados, um que parece estar em decadência, e que ocorre no início da noite, quando alguém, geralmente já avô, começa a falar de sua casa sobre assuntos da aldeia, e o outro, provavelmente 
incorporado recentemente, que ocorre na "reunião". Na reunião, os homens (ou mulheres) são convocados para uma das casas para tratar de algum assunto e há uma sucessão de oradores, de forma algo semelhante ao que acontece nas assembleias do movimento indígena da região. A reunião é um contexto, mas parece também ser entendido como o tipo de fala utilizado nesses eventos.

Imabute, segundo o dicionário de Koop \& Koop (1985), é traduzível por lenda, porém, esta não seria uma tradução exata do termo, já que muitos relatos que o pensamento euro-americano tomaria por lendas não são assim classificados pelos próprios narradores. O termo significa, mais apropriadamente, algo como "as palavras de antigamente", correspondendo, em sua maior parte, a um número relativamente limitado de narrativas conhecidas amplamente. Há pouca variação no conteúdo das diferentes enunciações que obtivemos de uma mesma história, podendo, segundo os comentadores, estar mais ou menos completa, ou mesmo ser apresentada de forma errada. A própria coletânea de mitos dos Deni do Xeruã (Sass 2004) parece incluir muitos textos que não seriam propriamente imabute para os Deni do Cuniuá.

Os imabute demandam um contexto descolado do ordinário, no qual pode ser apropriadamente transmitido o discurso que versa sobre um tempo diferente do presente, agindo de forma diferenciada sobre o cosmos. Ima remete a um tempo semelhante ao presente, podendo ser enunciada sem qualquer precaução contextual, pois parece não acessar as potências perigosas dos primórdios. Essa separação pode ter relação com diferenças na forma e local de enunciado, mas não pudemos recuperar estas características para todas as narrativas.

As condições da pesquisa, a presença do pesquisador inquirindo aqueles que se mostravam dispostos a falar sobre imabute, resultou na maioria das histórias terem sido apreendidas dentro do depósito em que estávamos hospedados. Histórias que não teriam uma circulação tradicional e nem seriam propriamente imabute, sendo apenas falas (ima), foram transmitidas ao antropólogo, fixadas em gravações e agora são tocadas nos gravadores da aldeia. A diferença entre os tipos de fala parece remeter ao contexto interno a narração, sendo que a separação entre ima e imabute não é evidente para os não Deni.

Antes de iniciar o trabalho de campo propriamente dito, dois dias após estabelecer o primeiro contato com os Deni, observamos um enunciar, para um 
funcionário de uma das ONGs que atuam na região, uma história sobre o tempo em que os bitha (piuns - uma mosquinha hematófaga, com aproximadamente 2-3mm, que assola a região) surgiram e dizimaram quase todas as aldeias existentes ${ }^{14}$. Findada a narração, o que estava escutando, por já estar familiarizado com o que se contava, esperou um pouco e perguntou sobre o restante da "história", mencionando os eventos que supostamente haviam sido esquecidos. Essa inquisição pareceu causar certo estranhamento no jovem Deni, mas, após escutar a suposta continuação, ele retomou a narrativa e descreveu mais alguns acontecimentos.

Sabendo da existência desta narrativa, num dos primeiros dias em campo, pedimos para um senhor nos deixar gravar a mesma na língua deni. Terminada a gravação, da qual não entendemos absolutamente nada, retomada a conversa em português, após alguns comentários, acerca do contexto em que a teria aprendido, ele disse: "isso ai é história, agora vou contar uma coisa que aconteceu mesmo". Passou então a narrar em português como um xamã, a pedido de sua nora que possuía sexualidade exagerada, trouxe os piuns de volta para a terra, mas agora eles já possuíam o tamanho e a potência atuais. Estes acontecimentos foram os mesmos que o funcionário da ONG pressupunha ser a continuação esquecida do texto sobre os bitha, mas, na realidade, tratava-se de registros diferentes, situados em tempos distintos.

Os imabute são relatos de um tempo quantitativamente diferenciado, onde as potências eram maiores: os insetos mais mortíferos, o rapé ${ }^{15}$ mais poderoso, etc.. Não se trata, apenas, de um momento em que os animais ainda eram gente, ou de um "contexto comum de intercomunicabilidade" (Viveiros de Castro 2002: 354) entre humanos e não humanos, mas, também, de um espaço em que as potências são exacerbadas e no qual a humanidade era menos humana, ou melhor, não o era de forma apropriada. Os xamãs que, nos dias de hoje, acessam os poderes dos tempos míticos, correm o risco de perder a sua humanidade e tornarem-se bichos (zumahi).

Zumahi é uma categoria de seres malignos-predadores-antropofágicos cujo protótipo é a onça ${ }^{16}$ (zumahi), mas não uma espécie em particular. A própria onça animal é um ser diminuído nos dias de hoje, incapaz de matar pessoas, mas que nos

\footnotetext{
${ }^{14}$ Trataremos dessa narrativa no próximo capítulo.

${ }^{15} \mathrm{O}$ rapé é um dos elementos principais do xamanismo e da vida cotidiana.

16 Todas as onças animais são zumahi, mas cada espécie recebe uma denominação particular: onça pintada - zumahi putahari, maracajá - zumahi birihari, onça vermelha - zumahi makhuvi, etc.. A espécie de cobra tida como a mais letal de todas é nomeada zumahi makha.
} 
relatos do passado é um dos predadores de humanos. Zumahi faz parte de uma classe maior de elementos nocivos do cosmos: zamahira (zama - coisa, hira - ruim), que inclui cobras, botos, jacaré-açu, tukurime (espíritos), venenos, aranhas, lacraias, etc., e também muitas coisas do kariva (karivakha zama ${ }^{17}$ ), como cachaça, terçados, machados... São elementos que podem (em potencia e também em ato) causar mal aos humanos, cuja agência pode ocorrer contra os humanos. Os objetos do kariva são particularmente ilustrativos, pois, embora sejam úteis e benéficos, os homens Deni fazem questão de mostrar as cicatrizes em seus corpos e comentar sobre a perda de sangue resultante das agressões das ferramentas.

O xamã que trouxe os piuns de volta para a terra não era zumahi nem estava situado na época dos imabute. Transferir seres entre facetas do cosmos é uma das atribuições comuns aos pajés, os próprios piuns só aparecem atualmente na terra, segundo algumas pessoas, como resultado da sua ação. A existência de versões gigantes e mortais dos minúsculos insetos atuais é o que situa a narrativa dos bitha em outro tempo ${ }^{18}$ que não o atual.

A divisão entre os tempos situados nas narrativas, para os Deni, não se situa numa clara distinção das fontes, não parecendo ser possível estabelecer uma genealogia de transmissão. Parece ser o contexto e os eventos internos que permitem situar no tempo o relato que está sendo feito. Não parece existir uma clara distinção entre uma marcação explicita de fontes e da cadeia de transmissão para narrativas que remetem a um tempo semelhante ao presente e uma referência genérica "aos ancestrais" para as do tempo mítico, tal como parece ser o caso Waiãpi (Gallois 1994). Há, por um lado, como já mencionamos, eventos como o retorno dos bitha para a terra que, embora não estejam em uma cadeia de transmissão conhecida, são considerados como estando em um passado relativamente recente e não nos primórdios e; por outro, alguns acontecimentos narrados são passíveis de terem sua cadeia de transmissão reconstituída.

\footnotetext{
${ }^{17}$ A partícula_kha indica posse. Karivakha indica que é do kariva. Zama é um termo complexo, que aqui teria o sentido de "coisa", mas que também indicaria a floresta. O dicionário de Koop \& Koop fornece: "Zama (s2g.) coisa; comida; mato, ato de (com verbo); coisa como (com substantivo)" (1985: 97).

${ }^{18}$ Vale mencionar que há uma narrativa que aponta o oposto para o caso dos humanos comuns. Eles inicialmente eram frágeis, morrendo de picadas de formigas pequenas e por ficarem presos aos espinhos que os prendiam na mata, eventos extremamente comuns durante uma caminhada pela floresta. Essa humanidade foi extinta ou habita atualmente no subterrâneo, voltaremos a isso no capítulo 3.
} 
Tomemos um dos raros exemplos em que seria possível apreender os vínculos entre as fontes. Ele foi narrado por um homem na casa dos 30-35 anos morador da aldeia Cidadezinha.

"O Salvador contou essa história. Ezei dizia que o Cuniuá era um lugar de muita morte, que aqui tinha muita doença. Ela subiu o rio e todos os seus sobrinhos foram morrendo, não ficou nenhum vivo. Eles paravam em um lugar e morria gente. Continuavam a subir o rio, paravam e morriam mais pessoas."

Salvador, indicado no início, era um homem (já falecido) muito velho que morou na mesma aldeia do narrador e cujos filhos (já avós e bisavós) habitam na aldeia Cidadezinha. Muitas pessoas atribuem a ele um grande conhecimento sobre histórias, sendo apontado como fonte imediata de muitas narrativas. Ezei, por sua vez, teria vivenciado e visto os acontecimentos que se desenvolvem, sendo a fonte originária do relato.

Nos comentários sobre a narrativa, o homem indica que Ezei e Salvador se conheceram quando este último era bem pequeno, mas os comentários sobre Ezei param nisso. Embora tenha sido contemporânea de uma pessoa falecida em data relativamente recente, conhecida por grande parte das pessoas vivas com mais de 30 anos, não há uma memória difundida de Ezei para além desta narrativa, não se sabe sobre seus descendentes $^{19}$, ou de que subgrupo ${ }^{20}$ _deni faria parte, ou mesmo menção sobre sua participação quando narram a reunião no alto Cuniuá dos três fluxos Deni: o que subiu o Cuniuá $^{21}$, o que veio do Pauini e o que veio do Xeruã.

A memória de Ezei é enunciada quando tecem considerações sobre a insalubridade de condições no rio Cuniuá. Ela é acionada toda vez em que se procura entender, ou explicar para o antropólogo, porque as taxas de mortalidade nas aldeias Deni do Cuniuá, onde morrem pelo menos duas pessoas adultas anualmente, são muito superiores as do Xeruã, nas quais, segundo os Deni da Cidadezinha, após a epidemia de sarampo dos anos 1980-1990, só teria falecido um homem adulto. Ele foi vítima de um

\footnotetext{
${ }^{19}$ Uma pessoa indicou a possibilidade de que ela fosse avó do pai do homem mais velho da aldeia Marrecão, com, aproximadamente, 80 anos em 2012. Esta informação, porém, não surgiu durante o processo de construção da genealogia deste senhor, durante o qual foi possível obter dados para seus pais e avós paternos sem ser mencionada uma ligação com Ezei.

${ }^{20}$ Os subgrupos serão abordados no próximo capítulo.

${ }^{21}$ Quando muito, fazem comentários em que dizem ter sido "o irmão de Ezei” que subiu o Cuniuá, sem nomeá-lo.
} 
xamã que o matou após ele ter caído de um pé de açaí em cima de um terçado. Mesmo que seja possível estabelecer uma genealogia de transmissão (Salvador, um velho, contou aquilo que teria escutado de Ezei, um velha quando ele era novo), o evento ocorreu em um tempo similar ao presente porque as condições onde se desenvolve são as mesmas que as atuais: há hoje grande mortalidade no Cuniuá, tal como já havia sido apontado por Ezei.

Parece haver entre os Deni uma distinção entre (1) aquilo que teria acontecido há muito tempo (na marcação temporal nizamani, que poderia ser aproximada a "antigamente" em português), algumas vezes marcado nas gravações pela palavra inicial imabute $e^{22}$; (2) aquilo que teria acontecido, sido observado ou narrado por alguém já morto, mas que se situa no limite externo da memória genealógica, isto é, teria ocorrido entre a época que os avôs ou pais de algum dos velhos estava vivo, ou na aldeia onde moraram, não sendo, necessariamente, indicada a fonte primeira (marcação temporal methamani, que também é válida para a próxima divisão temporal, indicando o passado que incluí desde o anteontem até períodos mais recuados); e (3) aquilo que aconteceu durante a própria vida de alguém ainda vivo ou recém-falecido. Entre os dois primeiros casos não há uma forma de distinção clara, os eventos podendo ou não ser situados em momentos muito recuados no tempo segundo a visão particular do próprio narrador/comentarista.

A cadeia de transmissão não parece ser algo muito presente quando se narra (ao menos para o antropólogo), pois, raramente alguém inicia uma história pela indicação de quem teria sido sua fonte. Para os casos não explicitados, quando se pergunta como tomaram conhecimento de determinados eventos que não presenciaram, geralmente apontam a pessoa que teria fornecido a versão que estão reproduzindo, sem haver uma preocupação em continuar indicando a transmissão até uma fonte originária. A credibilidade dos enunciados parecendo estar no último emissor, que pode ou não estar mentindo.

A visão é tida como geradora do conhecimento, seja do xamã que narra o que vê, ou das pessoas comuns que, nos rituais, cantam as músicas das coisas que viram. Após ter sido fixado em palavras, o conhecimento não necessita de uma indicação precisa de quem o vivenciou. Quando pessoas comuns enunciam características do mundo, podem

\footnotetext{
${ }^{22}$ Um senhor da aldeia Marrecão durante uma estadia na aldeia Cidadezinha nos narrou um imabute iniciado pelo termo nihapuni - "(adv. f.) antes” (Koop \& Koop 1985), mas isso não era muito comum.
} 
dizer que um xamã falou determinada coisa, sem que seja necessário nomear precisamente qual deles. A mensagem parece nunca ser falsa, exceto nos casos em que uma pessoa mente ao fazer uma enunciação, existindo aquelas que são tidas por mentirosas e cujos discursos sobre tempos recentes são desacreditados, tal como é generalizado para os kariva.

Houve um caso, inclusive, no qual um narrador apontava seu pai como fonte de uma história, mas ao consultarmos outras pessoas, elas indicaram que se tratava de uma narrativa que ele teria aprendido junto aos brancos. Tal como acontece entre os Piro (Gow 2001), situar algum velho, o pai, ou o sogro como transmissores parece ser o suficiente para estabelecer a provável veracidade da narrativa; sendo que o mesmo poderia ser dito sobre a profundidade temporal dos enunciados. Do ponto de vista dos netos que escutam seu avô narrando, os acontecimentos que teriam como fonte o pai ou o avô de seu avô $\left(\mathrm{G}+3^{23}\right.$ ou $\left.\mathrm{G}+4\right)$ já situariam o primeiro emissor entre os ancestrais (“ancient people” - Gow 2001: 90) não conhecidos.

Este é o caso de Ezei, sobre a qual nada sabemos além da narração de sua subida pelo rio Cuniuá. Os jovens e crianças de hoje, muitos dos quais tiveram o primeiro contato com a narrativa em função de nosso trabalho de campo, não foram contemporâneos de Salvador, assim Ezei passará para o tempo dos antigos sem conexão conhecidas com os dias atuais. Os eventos de seu discurso, entretanto, provavelmente permanecerão relacionados ao tempo presente, isto é, como tendo ocorrido em um tempo quantitativamente igual ao atual, já que apresenta as mortes no Cuniuá, que aconteciam tanto na época da sua subida (tempo da narrativa) quanto nos dias de hoje, não sendo possível estabelecer um corte entre estes eventos e as qualidades observadas na região, com seus espíritos (tukurime), patógenos e mortes.

Não podemos discorrer apropriadamente sobre as formas tradicionais de transmissão das narrativas Deni, pois o procedimento adotado em campo levou a sua separação em relação aos seus contextos performativos. Isto representa uma perda no que tange as formas como estes conhecimentos se transmitem, pois não poderemos

\footnotetext{
${ }^{23}$ Seguimos ao longo da tese algumas convenções para descrição do parentes. Utilizamos a seguinte

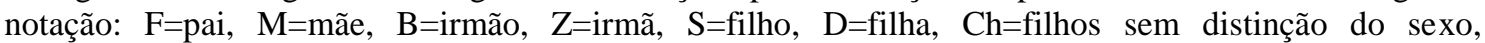
$\mathrm{H}=$ marido, $\mathrm{W}=$ esposa. Os termos compostos (FM, FB, ZS, etc.) devem ser lidos da direita para a esquerda, ou seja, FM deve ser lido como "mãe do pai". Além desses termos existem marcadores de idade relativa, $\mathrm{e}=$ mais velho $\mathrm{e} \mathrm{y}=$ mais novo, assim $\mathrm{eB}=$ irmão mais velho. $\mathrm{E}$ quanto às gerações temos $\mathrm{G}+1$ como primeira geração ascendente, G+2 como a segunda, G+3 como a terceira..., G0 como a geração de Ego, e G-1 como a primeira geração descendente, G-2 como a segunda, G-3 como a terceira, etc.
} 
levar em consideração sua dimensão estética, não sendo possível tratar as narrativas como uma forma de arte verbal ${ }^{24}$. As narrativas são, aqui, consideradas como construções que permitem acessar fragmentos da sociocosmologia Deni, que é atualizada nos textos dos enunciados e que também é mobilizada no entendimento de eventos e ações.

A relação entre enunciações e práticas parece ocorrer em dois níveis, pois, por um lado, a memória fornece uma base para entender eventos e ações, mas, por outro, as narrações só ocorrem no decurso de certos acontecimentos e atividades. Algumas práticas, costumes e elementos rituais são diretamente associados com certas histórias, as quais eram comumente fornecidas ao antropólogo como espécies de explicação para sua execução. Performances orais espontâneas, como foi possível apreender das poucas vezes em que as presenciamos, são realizadas pelos mais velhos em beneficio dos mais novos durante os preparativos para certa atividade coletiva. Por exemplo, a que ocorreu em um dos nossos primeiros dias de pesquisa de campo, quando participamos de uma pescaria com tingui na mata. Antes de iniciar a pescaria, o homem mais velho da aldeia narrou uma história ${ }^{25}$ para as crianças que estavam a sua volta enquanto ele tecia um cesto de folhas que seria usado para transportar os peixes.

A outra ocasião em que presenciamos narrações espontâneas foi no contexto de realização de uma versão simplificada (intra-aldeã) de um imaamushinaha banivadanaha, uma grande festa inter-aldeã. Alguns homens adultos da aldeia Cidadezinha resolveram realizar parte de um ritual da sua "cultura" (Carneiro da Cunha 2009) para que pudéssemos observar. Queriam apresentar alguns elementos que entendiam como sendo genuinamente da "cultura" Deni, mas sobre os quais não gostavam de comentar detalhadamente para o antropólogo.

Embora tenha sido inicialmente pensada como uma festa pequena pelos homens na casa dos 30 anos, pois na versão normal deveria ser consumida uma enorme quantidade de bananas maduras e naquele momento não havia nenhuma, houve a participação de quase todos os moradores da aldeia, incluindo os velhos que, normalmente, não tomam parte nos frequentes rituais organizados pelos adultos e que

\footnotetext{
${ }^{24}$ Desconsideramos tudo o que diz respeito à métrica, estilo, repetição, paralelismo, etc., isto é, a dimensão poética e estética das narrativas (veja Hymes 1981; Franchetto 1989, 2003; Cesarino 2006).

25 Só nos foi indicado que estava ocorrendo uma narração, mas, infelizmente, dado o nosso desconhecimento total da língua e da impossibilidade de registrar a narrativa, não sabemos o conteúdo da história.
} 
envolvem partidas de futebol e forró noturno. Durante sua execução, contudo, eram comuns os comentários sobre como tudo seria magnificado quando da ocorrência do grande ritual: centenas de pessoas envolvidas, um grande roçado de banana plantado para a ocasião, caçadas de muitos dias, uma sequência de eventos em que as pessoas ficavam vários dias e noites sem dormir, etc..

Durante a confecção dos objetos necessários para a ocasião, atividade desempenhada pelos homens na mata, os mais velhos começaram a narrar para os jovens e crianças (enquanto ajudavam na confecção) algumas imabute a respeito de alguns dos personagens que estavam sendo fabricados e que iriam participar do ritual. Os velhos e novos sentaram-se próximos, enquanto os homens adultos se distribuíam nas proximidades, divididos em pequenos grupos de cunhados. Todos estavam ocupados na confecção de seus macacos, araras, queixadas, etc. com grande preocupação estética e variação entre eles: uma macaca estava com seu filhote, outro tinha uma coloração (palha) diferente na cabeça...

Embora seja uma performance isolada, este é provavelmente um dos modo da tradição oral Deni. Neste contexto, nessa situação específica, houve a narração de uma mensagem que deveria ser feita de uma forma determinada de enunciação (Jolly 2002). Durante a confecção dos personagens, a imabute sendo narrada (pelos velhos) e ouvida (por todos), era, por um lado, transmitida pelos mais velhos (tidos como seus conhecedores, mesmo que não as conheçam) e, por outro, deveria contribuir para produzir/criar/estabelecer/fazer conhecer a agência dos personagens do ritual ${ }^{26}$. Nesta ocasião foi possível vislumbrar a cosmologia Deni em ação, num momento em que mito e rito, discurso e ação são conjugados no presente.

Os Deni afirmam que existem outros três momentos em que ocorrem narrações de imabute: durante viagens e estadias na mata; durante a noite para os moradores da casa; e no contexto de grandes festas rituais inter-aldeãs. Durante nossa pesquisa de campo, pudemos perceber, nos momentos em que enunciados surgiram espontaneamente, a relação entre narração e afastamento em relação às casas. Durante uma das viagens que realizamos para as outras aldeias do rio Cuniuá, um dos nossos acompanhantes resolveu narrar histórias, durante a noite, sem ter sido solicitado a fazêlo e, em outra ocasião, pediram que eu contasse histórias durante um acampamento noturno em meio uma viagem para a cidade. Um de nossos narradores só narrava

\footnotetext{
${ }^{26}$ Sobre agência dos objetos ver Gell (1998).
} 
enquanto andávamos pelos caminhos da mata, muitas vezes impedindo um registro apropriado dos mesmos...

A grande maioria das pessoas dizia que as narrações noturnas, realizadas pelo homem mais velho de uma residência, eram a forma mais comum de transmissão no passado e correspondia ao modo como tinham aprendido os enunciados que nos faziam. Esta prática, segundo afirmavam, não seria mais realizada com muita frequência, pois não existiriam mais os grandes conhecedores de imabute, todos já falecidos. Fomos convidados, em dois momentos, para realizar gravações noturnas de narrações, porém não saberíamos dizer se elas teriam acontecido sem a nossa presença. Estes momentos, contudo, foram semelhantes as performances apontadas por Gow (2001) para os Piro, em que os avôs fazem discursos sobre o passado na presença dos netos.

Todos os rituais coletivos em que a animação ${ }^{27}$, brincadeiras e refeições coletivas estão presentes são chamados imaamushinaha e traduzidos por "festa" em português. Os grandes rituais inter-aldeãos são nomeados imaamushinaha banivadanaha e envolvem o cultivo de grande quantidade de pés de banana, a realização de uma grande caçada coletiva, têm duração de muitos dias e uma sequência de atividades que duram o tempo todo, do seu inicio até o fim. A execução de grades rituais parece ser algo do passado, pois nos últimos 10 anos só teriam ocorrido versões menores, incomparáveis com as que ocorreram 20-30 anos atrás ${ }^{28}$ e foram observados durante a infância de homens na casa dos 30-40 anos. Estas grandes festas do passado envolviam a construção de uma casa dos homens, na qual os velhos se revezavam na narração de imabute.

A relação entre estes rituais coletivos e as imabute é interessante, pois como mostramos, foi durante um imaamushinaha que observamos uma narração espontânea e parece que esta é uma associação forte. Alguns moradores da aldeia Cidadezinha reclamavam que os velhos da aldeia não contavam histórias durante as festas, mas sempre que iam até outra aldeia para um imaamushinaha, um velho do local se apresentava durante as refeições coletivas. Devemos considerar, contudo, que, quando estavam participando de um imaamushinaha em outra aldeia, este se tornava um evento

\footnotetext{
${ }^{27}$ A animação está relacionada com o crescimento infantil. Para uma descrição pormenorizada da relação entre animação e festas/rituais veja Florido (2013).

${ }^{28}$ Os rituais de 20 anos atrás seriam muito diferentes dos outros, pois envolveriam uma grande quantidade de pessoas. Durante sua execução é que se estabelecia a relação de itavari que será descrita no capítulo 3.
} 
inter-aldeão, cujo modelo ideal relatado envolve a presença de narrativas, diferente das festas cotidianas nas quais os mais velhos não participam.

Embora não seja possível estabelecer uma relação entre as narrativas que passaremos a analisar e os contextos em que seriam enunciadas espontaneamente, podemos ao menos estabelecer que algumas dentre elas não são simples enunciados casuais. Mesmo narradas ao gravador, longe das situações em que surgiriam espontaneamente nos discursos, algumas delas sempre demandavam uma mudança do ordinário, uma quebra do contexto cotidiano. Quando se trava propriamente de imabute e eram os mais jovens narrando, somente o faziam a portas e janelas fechadas, sem a presença de outras pessoas que já dominassem a língua ${ }^{29}$; os mais velhos tomavam menos precauções, porém não era incomum narrarem no escuro da noite, ou fazerem alusões a mata ser um local mais apropriado que o depósito, etc.. Elas demandariam um espaço/tempo não cotidiano, tal como os contextos apontados como apropriados para este tipo de enunciação.

\section{2 - O surgimento da humanidade atual}

Durante o processo de registro dos imabute, a narrativa sobre o surgimento da humanidade atual, pela ação dos irmãos Tamaku e Kira, era frequentemente a primeira a ser mencionada ${ }^{30}$. Ela não corresponde ao marco inicial do cosmos, pois, invariavelmente, os Deni tendem a situar o inicio na época em que não havia água, isto é, atribuem uma anterioridade lógica, mais do que cronológica, aos eventos que deram origem a água, mesmo que não haja grande preocupação em incluí-los na educação do antropólogo. Os próprios Deni não parecem possuir qualquer preocupação em ordenar os acontecimentos de diferentes enunciados numa sequência temporal, tendo essa atribuição sido resultado do questionamento do antropólogo.

Todos situaram como evento mais antigo o surgimento da água, dando como justificava o fato de que ele ocorreu primeiro, porque antes não havia água. O que

\footnotetext{
${ }^{29}$ Crianças bem pequenas podiam estar presentes, isto é, as que ainda não dominavam a comunicação oral.

${ }^{30}$ É interessante apontar que, na coletânea de mitos Deni editada no Xeruã, Tamaku e Kira (Sass 2004) fazem a abertura do livro. Essa coletânea bilíngue circulou pelas aldeias do Cuniuá, onde há algumas pessoas alfabetizadas em Deni.
} 
ocorreu após isto, contudo, não é claramente ordenado. O procedimento que eles adotavam para satisfazer nossa curiosidade era tomar pares de histórias e estabelecer a anterioridade de uma com base no que era pressuposto na outra. Por exemplo, os eventos que envolviam a existência dos roçados só poderiam ter ocorrido depois do surgimento do primeiro roçado. Essa ordenação de episódios não resulta em uma classificação linear das narrativas, mas isso não é uma preocupação Deni.

A justificativa dessa aparente necessidade de garantir que Tamaku e Kira sejam conhecidos, antes de serem ensinadas outras coisas, parece repousar no grande potencial explicativo que eles possuem. Os eventos que estes irmãos criam e vivenciam se situam em um mundo fisicamente acabado, são eles que causam a organização dos humanos e também o surgimento de outros elementos e relações do cosmos. Eles criam em um mundo definido, mas despovoado. Trata-se de uma das tão difundidas narrativas sobre as aventuras de heróis criadores, na qual eles aparecem como os últimos grandes xamãs, que criam os humanos detentores das potências limitadas dos dias atuais.

A narrativa dos irmãos aborda muitas questões, mas, neste momento, não iremos levar em conta muitos elementos que nela se apresentam. O leitor poderá perceber que há uma vasta gama de temas presentes no mito: questões de gênero, maternidade, rituais, geográfica, etc.. Não poderíamos levar em conta todos estes aspectos desenvolvidos pelos heróis sem fugir ao tema desta tese, portanto, eles serão levados em conta posteriormente.

Apresentamos a versão mais longa possível de ser construída a partir dos diferentes enunciados de que dispomos e ela não corresponde exatamente a nenhum deles. Isso não quer dizer que iremos reproduzir todos os diálogos possíveis e sim que ela será composta a partir da menção a todos os episódios disponíveis. Estamos criando a "versão didática" (Gallois 1994: 24) mais completa frente aos nossos conhecimentos atuais e isto permitirá entender mais do que seria possível no caso de optarmos por um simples resumo dos elementos que serão explorados posteriormente. Ela é, em realidade, formada por acontecimentos iniciais, que apesar das variações nas ocorrências não mudam muito no eixo sintagmático ${ }^{31}$ dos discursos, seguidos por uma

\footnotetext{
${ }^{31}$ Queremos dizer com isto que acontecem as mesmas coisas, porém elas não se apresentam sempre da mesma forma. Indicaremos em notas de rodapé as diferenças disponíveis com relação a à versão que apresentamos. Na segunda parte há uma variação na continuidade da narração, que pode se abrir para incluir novos eventos.
} 
coleção de episódios que foram recordados dentre muitos outros que seriam possíveis e que ainda podem surgir, isto é, há uma variação na cadeia dos eventos.

\title{
Tamaku e Kira
}

\author{
Existiam muitas pessoas ${ }^{32}$. Uma delas era um pajé, Sinukari, que podia \\ $\operatorname{curar}^{33}$. Uma criança ficou muito doente, quase morrendo. Perguntaram para \\ ele: \\ - Você é pajé, então cura meu filho. \\ Ele não conseguiu curar a criança ${ }^{34}$ que acabou falecendo. As pessoas \\ começaram a acusá-lo de mentir sobre ser pajé. Ele não podia curar ninguém, \\ não tinha arabani ${ }^{35}$. Irritado com as acusações de todos, ele resolveu subir para o \\ céu com sua família. Tomou rapé e foi pelo caminho ${ }^{36}$. Assoviou com as mãos \\ para chamar o espírito do céu (zarava), que escutou e foi até ele. Os filhos e \\ esposa $^{37}$ foram colocados dentro do espírito ${ }^{38}$. Durante a viagem ao céu (quase) \\ todos morreram ${ }^{39}$.
}

\footnotetext{
${ }^{32}$ Um dos narradores fez questão de iniciar a história indicando que ela não teria ocorrido na região do rio Cuniuá. Ele apontava que ela ocorreu em um local muito distante.

${ }^{33}$ As variações no Cuniuá giram quase todas na temática da cura, exceto uma, cujo narrador aprendeu as histórias de um ex-morador do Xeruã. A versão do Xeruã não menciona cura: Sinukari, que só comia lagartas, não consegue indicar o caminho correto para as esposas encontrarem o alimento. A partir disto se inicia o desentendimento e a contestação sobre suas capacidades xamânicas. Nela são outras esposas (não a que irá ao céu) que o acusam (Sass 2004).

${ }^{34}$ As variações encontradas dizem: muitas pessoas haviam morrido e Sinukari se recusa a curar uma criança; são feitos vários pedidos não atendidos pelo pajé, seja pela negação do tratamento ou sua falha; tenta curar meninas de várias idades, mas acaba falhando em todas.

${ }^{35}$ Este seria o nome em português que os Deni traduzem o termo katuhe, a pedra-poder do xamã. Arabani é o termo usado por Rangel (1994) para indicar o "feitiço" entre os Jamamadi, podendo ser que o termo tenha se difundido entre os não indígenas da região a partir desta língua. Em paumari arabani seria a palavra correspondente a pajé (Salzer \& Chapman 1998).

${ }^{36}$ Há apenas outra versão elaborada sobre esse momento, que menciona que o xamã levou a família no roçado e passou urucum neles. A maioria só diz que ele queria subir ao céu e chamou o espírito que desceu até ele.

${ }^{37}$ Dois filhos e uma esposa, ou três filhos e a esposa, ou filha e a esposa... Há sempre a esposa e certo numero de filhos.

${ }^{38}$ Alguns especificam que os espíritos são como paneiros (Sass 2004), ou carregam uma espécie de panela. Uma das versões, narrada pelo homem mais velho da aldeia Cidadezinha, alternando o idioma entre português e deni durante a performance, aponta, em português, que os espírito foram colocados dentro dos viajantes.

${ }^{39}$ Podem ter feito viagens individuais ou uma só coletiva. Todos podem ter morrido, ou só alguns. Se há sobreviventes, a esposa sempre está entre eles.
} 
Irritado, Sinukari pegou um machado velho e começou a quebrar a(s) pedra(s) do céu. As pedras foram caindo junto com chuvas e ventos ${ }^{40}$. A água foi caindo na terra e rapidamente os rios encheram. Enquanto a água subia as pessoas ficaram com medo, gritando e chorando. A água cobriu a terra toda, não tinha mais nada. As arraias, botos e piranhas ${ }^{41}$ comeram as pessoas.

Tamaku e Kira eram dois irmãos, Tamaku era o mais velho. Eles pegaram uma canoa de casca de árvore ${ }^{42}$ e começaram a subir com o nível da água, desviando das pedras ${ }^{43}$. Só eles ficaram vivos, todas as pessoas haviam morrido. Ficaram na canoa e o mundo todo tinha virado água, só sobrou uma árvore muito alta onde amarraram a canoa.

Nesse tempo o piolho era grande ${ }^{44}$. Eles pegavam e cortavam no meio para comer. Tamaku pegava os piolhos na cabeça de Kira e cortava. Eles estavam magros de fome.

- Kira ${ }^{45}$, junta suas mãos e assopra para baixar a água ${ }^{46}$.

Kira criou a friagem ${ }^{47}$. Kira soprou fraco, ficou frio, mas a água baixou só um pouco. Ele soprou de novo, a água estava secando devagar. Quando a água parou na metade da árvore Tamaku falou:

- Kira, mergulha na água ${ }^{48}$. Vai até a terra para ver como estão nossos parentes $^{49}$.

Kira pulou na água, mas ele não foi fundo ${ }^{50}$. Tamaku o viu deitado ${ }^{51}$ na superfície da água, olhando para o fundo. Kira saiu da água e mentiu dizendo que foi até o fundo e viu as casas. Seu irmão disse:

\footnotetext{
${ }^{40}$ Ou só uma pedra, a partir da qual a água saiu.

41 Ou jacaré-açu, cobra grande, ou simplesmente um "bicho". Arraia, boto e jacaré-açu não são comestíveis; "bicho" é uma categoria de seres malignos cujo protótipo seria uma onça.

${ }^{42}$ Uma das versões aponta que Kira fez a canoa, as outras dizem que foram "eles".

${ }^{43} \mathrm{Na}$ versão do Xeruã (Sass 2004), as pessoas pedem para entrar na canoa, mas eles não permitem dizendo: "Vocês xingaram o pajé, por isso aconteceu essa tragédia" (Sass 2004: 17).

${ }^{44}$ Os piolhos são um elemento da versão do Xeruã.

45 Os nomes foram usados para facilitar a identificação, mas quase sempre eles estão usando termos de parentesco vocativo: $a z u$ (irmão mais velho) e shuvi (irmão mais novo).

${ }_{46} \mathrm{Na}$ versão do Xeruã, Tamaku manda Kira arrancar as unhas.

${ }^{47}$ Segundo algumas versões, começou a secar antes de Kira soprar a primeira friagem.

${ }^{48}$ Xeruã: desce por um cipó.

${ }^{49}$ A partir dessa parte, na narrativa estabelece que Kira é o irmão menos habilidoso. Esse episódio é o que apresenta maior variação. Alguns dizem que ele foi procurar pela casa, outro que era pra ver os parentes, ou ver como estava a terra e outros não especificam. O que se encontra são enfeites e redes, ou a casa vazia, ou as pessoas mortas. O relevante pare ser que Tamaku manda Kira ver como estavam a terra e a humanidade anterior, mas este não realiza a tarefa de forma apropriada.
} 
- Você não foi até o fundo, agora vou eu.

Tamaku foi até o chão e viu. Só havia redes, enfeites corporais ${ }^{52}$. Ele soprou uma flauta. Voltou e perguntou se Kira tinha ouvido. Kira disse que $\operatorname{sim}^{53}$.

Ainda tinha muita água, então Tamaku soprou a friagem. Era uma friagem forte, ficou muito frio e Kira começou a tremer e a chorar, reclamando. Tamaku jogou água em Kira que ficou com mais frio e depois o jogou na água ${ }^{54}$.

Eles continuaram a soprar até que a água secou quase toda, já era terra novamente. Quando terminou a água os dois chegaram à aldeia deles. Eles choraram muito por causa dos parentes deles que tinham morrido ${ }^{55}$.

- Nossos parentes morreram todos. O que vamos fazer ${ }^{56}$ ?

- Kira, vamos para lá.

Foram para a floresta. Andaram um dia e dormiram.

- Kira, vamos fazer uma casa.

Tiraram paixuba e palha. Teceram. Terminaram a casa e deixaram lá. Continuaram andando. Fizeram outra casa. Andaram e fizeram outra... Fizeram muitas casas ${ }^{57}$ e pararam na última.

Tinha um lago. Tamaku e Kira pegaram um cipó de cheiro bom e foram batendo até a água secar. Virou um roçado.

\footnotetext{
${ }^{50} \mathrm{Em}$ uma das versões ele não vai até o fim porque ainda estava muito fundo e lá era muito escuro, fazendo o ter medo.

${ }^{51}$ Ou sua cabeça.

${ }^{52} \mathrm{Em}$ uma das versões, ele pega uma flauta (um pedaço de taboca com furos, parecido com uma flauta doce) ou apito (uma semente furada), em outra, Kira deveria tocar a flauta ou a buzina (um vazo cerâmico no qual se assopra através de um pedaço de taboca) para indicar que chegou ao fundo. Nessas versões, ele mente sobre ter tocado os instrumentos.

${ }^{53}$ Xeruã: Kira mente dizendo que não escutou, que tinha visto a cabeça do irmão que não foi até o fundo.

${ }^{54}$ Em uma das versões, Tamaku depois cria o sol para aquecer Kira. Obtivemos uma narrativa independe sobre o surgimento de sol e lua, mas ela não parece ter uma ampla distribuição no Cuniuá, estando presente, contudo, na coletânea publicada de mitos Deni do Xeruã (Sass 2004).

${ }_{55}$ A parte fixa da narrativa acaba aqui, a sequência de eventos que se seguem é variável. Só há outro episódio que sempre está presente, não necessariamente antes de outros. É o da recriação dos humanos, cuja versão do Xeruã é baseada na ingestão de poraquê ocorrida após o plantio de flechas. Não iremos mais indicar diferenças entre as versões, pois acreditamos que eles não fariam parte de uma só narrativa. Os episódios que apresentaremos são baseados em nossa pesquisa de campo; na coletânea do Xeruã são apresentados outros.

56 "O que vamos fazer", ou "o que vamos inventar" é uma expressão comum nas narrativas Deni. Seguese a ela a criação de algo que não existia anteriormente, algo é feito pela primeira vez; seja uma coisa ou ação.

${ }^{57}$ Fizeram cinco (especificado) casas.
} 
- Kira, vamos procurar pessoas.

Andaram pela mata e encontraram uma arvore de zavi (uma palmeira como o tucumã). Ela era baixinha e tinha um cacho grande carregado de frutinhas.

- Kira você sobe e derruba. Eu vou ficar aqui.

Kira subiu e derrubou. Tamaku ficou virado de costas pra cima para a fruta cair de vagar. Ele pegou o cacho que caiu e colocou longe.

- Agora eu vou subir. Você fica aqui e faz como eu Kira.

Ele cortou o cacho, mas Kira ficou com medo e pulou para o lado. O cacho caiu no chão e as frutas se espalharam. Tamaku ficou com raiva e brigou com Kira.

- Não faz isso Kira. Agora vamos procurar lagarta.

Eles saíram procurando lagarta. Kira achou uma lagarta grande, preta, pendurada de cabeça para baixo em uma arvore baixa. Ele chamou o irmão que propôs.

- Vamos cortar no meio. Cada um fica com um pedaço. Vamos vomitar gente como nós.

Dividiram e colocaram na boca. Comeram. Passou um tempo e Kira começou a vomitar. Iam saindo pessoas, mas eles falavam outras línguas e eles não entendiam. Ele vomitou novamente, outra vez, outra... Ele vomitou muitas vezes, sempre saiam pessoas que falavam línguas diferentes. Tamaku deu um chute nas nádegas de Kira e ele parou de vomitar. Tamaku disse:

- Agora eu vou vomitar. Vai sair nossa gente, você só fica olhando.

Tamaku começou a vomitar. Iam saindo pessoas que falavam a língua deles. Vomitou poucas vezes ai Kira chutou as nádegas dele. Ele parou de vomitar. Ficou com raiva.

- Porque você fez isso Kira? Eu estava vomitando nossa gente. Agora vamos ser poucos.

Tamaku estava com muita raiva. Ele pegou o cacete e quase matou Kira. Ficaram lá um tempo. Tamaku mandou que as pessoas que ele vomitou ficassem 
nas casas que eles construíram. Na última casa ele mandou ficarem quatro mulheres, duas esposas para cada um.

Tamaku e Kira foram caçar. Naquele tempo eles caçavam morcego de casa, morcego que mora perto do rio e passarinho pequeno. Mataram muitos com dardo de zarabatana, moquearam e dividiram em dois paneiros bem cheios.

- Vai na frente Kira.

O pessoal da casa viu ele se aproximando.

- Lá vem o Kira, ele está trazendo caça para nós.

Tinha muita gente. Kira passou, mas pegaram metade da caça dele. Depois passou o Tamaku, mas não conseguiram pegar nada. Chegaram em outra casa, dessa vez esvaziaram o paneiro de Kira.

- Kira, não faz isso. Você deixou pegarem, tem que correr. Vamos caçar novamente e encher um paneiro para você.

Caçaram morcegos e passarinhos, moquearam tudo e encheram o paneiro de Kira. Novamente ele andou devagar e pegaram toda a sua caça. Tamaku conseguiu passar. Chegaram então na última casa, onde moravam. As mulheres falaram:

- Hoje nossos maridos vão chegar.

Eles chegaram perto e deixaram a caça no terreiro. Depois beberam suco de patauá. Acharam muito gostoso o patauá misturado com tapioca. As mulheres comeram no terreiro. Eles perguntaram pelas esposas e apontaram quais eram. Cada um tinha duas esposas.

De noite Tamaku foi ter relações sexuais com a esposa. Kira não, ele só dormiu. Kira não sabia fazer sexo, ficava esfregando o pênis entre os dedos do pé da esposa. As mulheres de Tamaku logo ficaram grávidas. Ele perguntou para a cunhada.

- Kira faz sexo com você?

- Não, ele não faz sexo comigo, fica só esfregando entre os dedos.

- Onde está seu marido?

- Foi caçar. 
- Quando ele chegar eu venho aqui. Você fica de pernas abertas esperando. Vou pegar ele e jogar em cima de você.

Kira voltou da caçada, estava chovendo no mato. Ele estava com muito frio e foi para perto do fogo aquecer. Tamaku foi perto dele, pegou o irmão e jogou sobre o peito da esposa que estava de pernas abertas. Tamaku ficou pisando nas costas de Kira. $\mathrm{O}$ pênis dele furou a vagina da esposa que gostou. Kira ficou animado, exclamando que tinha entrado na esposa. Ele fez sexo com as duas esposas e logo elas ficaram grávidas.

Cada um tinha feito seu um caminho de caça. Tamaku sempre matava muito, mas Kira nunca matava nenhum. Kira fez seu caminho, no final dele encontrou um tronco bonito caído. Ele parou e se masturbou.

- Kira, você nunca mata nada. Vamos trocar de caminho hoje.

Tamaku foi pelo caminho de Kira, encontrou o tronco caído e viu o sêmen de Kira. Ele juntou todo ele, fez jacaretinga e ovo de jacaretinga. Colocou no tronco e voltou.

- Kira, amanhã você vai no seu caminho. Eu vou no meu.

Ele foi pelo caminho e encontrou o ovo no tronco. Ele ficou muito animado. Pegou o ovo, matou o jacaretinga e levou de volta para a casa. Cozinhou e comeu com fome. Tamaku voltou.

- Tamaku, aqui está seu ovo. Pode comer.

- Não vou comer. Isso faz mal para mim.

Alguns dias depois o ovo se transformou em um urunaha ${ }^{58}$ muito grande na bunda do Kira. Ele gemia de dor. Tamaku foi fazer arco e flecha pequenos e voltou onde estava o irmão, este gritava de dor.

- Vem para perto Kira, vou tirar esse pus.

- Não dá. Está doendo muito.

Tamaku flechou, a ponta da flecha estava bem afiada. Furou o meio do tumor. Kira gritou.

- Tamaku, está doendo muito.

\footnotetext{
${ }^{58}$ Um abscesso purulento.
} 
- Aguenta Kira.

Tamaku puxou a flecha e saiu muito pus. Ele pegou rapé e cheirou. Deu para Kira.

- Kira, passa esse rapé.

Ele passou rapé e conseguiu dormir, quando acordou estava bom.

- Tamaku, fiquei bom.

Kira ficou menstruado. O irmão dele jogou arabani de longe e ele engravidou. Um dia ele teve uma filha. Tamaku tinha ido caçar no mato. Kira ficou sozinho e teve o bebe. Quando o irmão estava voltando ele ouviu a criança chorando. Disse:

- Kira teve uma filha.

Tamaku chegou onde estava Kira.

- Tamaku, aqui está nossa filha.

- Kira, não faz isso comigo não.

Tamaku pegou a criança e jogou numa arvore, ela ficou grudada. Virou um cupinzeiro ${ }^{59}$. O cupim viveu mais do que Kira. Mexe com ele e fica doente.

Kira chorou muito por causa da filha dele.

No outro dia.

- Kira, vamos fazer roçado.

Pegaram cipó cheiroso, muito cipó. Bateram o cipó. Foram batendo e deixando marcado. Virou roçado. Tinha muito milho. Foram para casa. Tamaku disse:

- Kira, não vai ao roçado. Eu vou caçar, depois nós vamos.

Quando Tamaku saiu Kira foi ao roçado. Tinha muita macaxeira, banana. Kira pegou duas espigas de milho e comeu. Voltou para casa e um pouco depois Tamaku chegou.

- Tamaku, tem muito milho no roçado.

\footnotetext{
${ }^{59}$ Uma espécie de cupim chamada kirabedeni, literalmente, a filha de Kira.
} 
- Kira, falei para você não ir ao roçado. Eu iria primeiro.

- Eu não tirei nada.

- Me deixa ver sua boca.

Ele viu um pedaço de milho preso no dente e cortou o lábio de Kira. Kira chorou muito. Tamaku jogou o lábio na água e virou cará ${ }^{60}$.

- Depois que a gente morrer vão falar que é o lábio de Kira.

Esses eventos ocorrem em um mundo cuja geografia já está acabada, existiam os rios, as plantas, os seres não humanos (os passarinhos pequenos, os morcegos, as lagartas; tucunarés e poraquês no Xeruã). A humanidade, contudo, era um conjunto indiferenciado, cuja extinção permitiu instituir a descontinuidade entre os humanos. Com o fim da humanidade anterior e o surgimento de grupos diferentes a cada regurgitação dos heróis, o discreto surge a partir do fim do contínuo, e isto permite conceituá-lo (Lévi-Strauss 2004 [1964]), ou seja, ele funda a possibilidade de uma reflexão sociológica Deni. Talvez seja nisso que resida o grande valor explicativo de Tamaku e Kira, constituindo-se como modelo de inteligibilidade para os novos eventos.

Trata-se de um mito que é pleno de significação e seus elementos estão presentes nas práticas cotidianas. Temos, de um lado, a ação de Tamaku e Kira estabelecendo elementos do cosmo que são independentes da ação humana, como a friagem, o cará, a jacaretinga, o perigo do consumo de ovos (em especial os de jabuti e jacaré que podem levar ao surgimento de feridas purulentas no corpo), a menstruação, etc., e, de outro, a incorporação de práticas culturais reproduzidas atualmente, o consumo ritual de keriha (suco de patauá com tapioca), o uso de flechas, o uso de rapé para curar ferimentos e para dormir, o sexo, a prática de molharem uns aos outros durante as friagens ${ }^{61}$, a de correrem com caça para as pessoas pegarem (kashinava), etc.. Não apenas isso, ele, também, estabelece as potências dos xamãs, isto é, as três grandes áreas de atuação dos

\footnotetext{
${ }^{60}$ Um tipo de peixe conhecido por cará na região e chamado kira ipu na língua deni, literalmente, lábio de Kira.

${ }^{61}$ Quando ocorre uma friagem muito forte, é comum que os homens e mulheres comecem a molhar uns aos outros, culminando com um banho coletivo no rio.
} 
xamãs Deni: os processos de cura e adoecimento/destruição, de obtenção de alimento e da reprodução humana.

Não é sem razão que o cristianismo tenha sido apreendido via Tamaku e Kira. O mais velho Deni com quem conversamos, após ter apresentado essa história, comentava que Tamaku e Kira eram Deus, Kira o nosso e Tamaku o deles, pois foram eles quem nos criaram. Tal associação, contudo, não está fixada desta forma. Na reavaliação atual do cristianismo é Sinukari, o xamã inicial, que passou a ser associado com Deus, o que é explicito na coletânea de mitos do Xeruã, quando mencionam que "Tamaku rezou para Sinukari” (Sass 2004: 19). Tal associação tem crescido no Cuniuá, tanto por ação dos missionários ${ }^{62}$, quanto pelo aumento da influência dos Deni do Xeruã entre eles como o Xeruã é percebidos como estando em melhores condições, devem ter mais conhecimento. O que parece interessante, contudo, é que, na ausência de uma bíblia na língua deni, é a esta narrativa que, seja o pensamento dos próprios indígenas, ou o dos missionários, se associa o universo cristão.

Por tratar-se de uma narrativa que institui o descontínuo a partir do contínuo, Tamaku e Kira acabam figurando como um molde para que se possa restituir a continuidade ${ }^{63}$, ou seja, permite estabelecer uma unicidade entre os cosmos cristão e Deni. Quer dizer, os Deni interpretam as narrativas sobre o cristianismo à luz de Tamaku e Kira, enquanto que o proselitismo missionário os vê como ponto para difundir suas próprias crenças. Ambos, indígenas e religiosos, fazem convergir o cristianismo para este ponto, para os Deni, pelo entendimento dos eventos em suas próprias estruturas.

Não é apenas o cristianismo, mas, todos os novos elementos do cosmos que passam a ser conhecidos são digeridos, pelos Deni, dentro do que é estabelecido nessa narrativa. Os comentários acerca desses eventos apontam que o diluvio ocorreu a partir de onde hoje se localiza Manaus, o que surgiu, provavelmente, quando da primeira viagem de um Deni para a capital do estado, mas ela se torna evidente para cada um que lá retorna, pois existem, segundo sua associação, muitas casas feitas de pedras por lá as pedras que Sinukari derrubou do céu e são praticamente ausentes na região da TI Deni. Manaus era, inicialmente, o local dos Deni e tal identificação permite evocar as

\footnotetext{
${ }^{62}$ Um Deni dizia que uma das missionárias apontava que Sinukari seria Deus e Mahaniru, personagem da narrativa sobre a invenção dos roçados, seria Jesus.

${ }^{63}$ Sobre a relação dialética entre o contínuo e o descontínuo no pensamento indígena e de Lévi-Strauss veja Lolli (2005)
} 
ideias acerca da troca de condições de vida entre índios e brancos. A cidade era o modo de vida Deni, mas eles foram enganador pelos brancos que ficaram com ela. Os termos em que aconteceu essa troca não se tornam elemento de discurso, apenas o que seria sua causa, uma diferença quantitativa de conhecimento dos brancos, que saberiam mais do que os indígenas.

Não se tem uma preocupação com a origem da espingarda, do metal ou das maquinas, não se elabora sobre a troca de mãos desses objetos, ou sobre a "má escolha [...] para dar conta da superioridade material dos brancos" (Viveiros de Castro 2002: 203), mesmo porque durante muito tempo eles viveram juntos e nas mesmas condições que muitos destes, apresentando nos dias de hoje, inclusive, um maior número de bens de consumo que a maioria dos brancos das proximidades. Todas as mercadorias consumidas na região chegavam (e em grande parte ainda chegam) através de barcos, assim, tanto indígenas quanto os brancos das margens dos rios e cidades da região recebem os produtos vindos de Manaus.

A superioridade material frente a alguns brancos é percebida, tanto em relação àqueles que habitam em casas nas margens dos rios, quanto a alguns moradores das cidades. Durante uma passagem da equipe de combate a malária da Fundação Vigilância em Saúde (FVS), um dos funcionários olhava para o conjunto de gravador e autofalantes do agente indígena de saúde, um dentre os muitos aparelhos que existem na aldeia, e se lamentava por não conseguir comprar um para si. Os Deni apresentam uma baixa dependência em relação aos produtos industrializados, à exceção das panelas, das facas, dos anzóis e linha e do sal, todos os outros elementos, embora apreciados, não são imprescindíveis, assim eles consumem muitos bens como DVDs, aparelhos de som, etc., não possuídos pela maioria dos não indígenas das proximidades, mas passam por períodos de escassez de café, açúcar, arroz, sabão (mas que tem diminuído dado o aumento das viagens para as cidades e o acréscimo da renda).

Esta escassez é, sempre, atribuída ao afastamento em relação às cidades e, não, por uma diferença nas capacidades produtivas ou de consumo. Os comentários sobre Tamaku e Kira frisam que não houve uma diferença no domínio sobre os bens, mas que houve uma inversão no local de moradia e nos tipos das casas; o local assume uma importância na sociocosmologia Deni. O que está colocado pela narrativa é que Tamaku e Kira, ancestrais dos Deni, moravam na casa que foi destruída a partir da queda das pedras do céu e eles abandonaram este local. Os heróis construíram novas casas para os 
humanos, num tempo em que as grandes casas coletivas era o corresponde das aldeias. Deixando de habitar onde estão disponíveis os bens e mercadorias, eles têm que se relacionar com os não indígenas que realizam seu transporte e os trocam com os produtos que existem na região agora habitada.

Um dos elementos que os Deni apontam como índices de serem indígenas são as casas que eles constroem, cujo formato geral retangular ${ }^{64}$ e os materiais utilizados atualmente não as distinguem das de muitos dos ribeirinhos: palafitas com uma armação de troncos, telhado de palha de caraná trançada em ripas de paixuba, que também fornece o piso. Afirmam, contudo, que, anteriormente, suas casas eram grandes e redondas como as dos Suruwahá ${ }^{65}$, a quem usam comumente para ilustrar como viviam antes. Não importa que tenham se aproximado do estilo regional de habitação, reputam outras diferenças em relação a estas: os kariva constroem casas de tábua, usam telhas de zinco. Não são poucos, contudo, os que reclamam da situação atual, apontando que deveriam morar em casas de tábua e com telhado de alumínio, o que é concretizado por um pequeníssimo número de pessoas dentre as que poderiam comprar esses materiais. Comumente, os que utilizam esses materiais compram apenas algumas tábuas, e alguns receberam estes materiais sob a forma de presentes.

A palavra $u z a$ corresponde a casa, com o sentido da construção física, o edifício de moradia. Casa, como sinônimos de lar, moradia, local de moradia seria_zamari (na forma possuída "minha moradia" uzamari), sendo comumente usado para se referir ao local de morada de animais, mas parece não estar restrito a eles, como aponta o dicionário de Koop \& Koop (1985). Para falar da habitação de uma pessoa, comumente, se usa o termo dathu, indicando, explicitamente, de quem é a casa. Por exemplo, dizem "vou na casa (dathu) de Marcelo", para indicarem que vão até onde Marcelo está morando e; "a casa (zamari) do Marcelo é longe", para se referir a casa dele em São Paulo, ou mesmo São Paulo como um todo, enquanto seu local/região de moradia.

\footnotetext{
${ }^{64}$ A distinção mais notável do formato diria respeito à ausência de paredes ao redor da casa. Elas são geralmente formadas por um telhado, um piso e paredes de paixuba formando um quarto, mas raramente paredes cercando toda a casa. Pouquíssimas casas apresentam paredes.

65 Os Makhukhu, como são chamados, são comumente usados pelos Deni para ilustrar o seu passado. Atribuem a estes a falta de saber que resulta em viverem como os próprios Deni no passado, isto é, andam pelados (o que é feio), moram ainda todos juntos, comem sem sal (mas já estão acostumando pelo convívio com os brancos, isto é, a Frente de Proteção Etnoambiental da FUNAI), comem morcegos (veja que é a alimentação do tempo de Tamaku e Kira), não sabem como tratar os parentes, são valentes (como os Deni antes de passarem a viver todos juntos), etc..
} 
Uza é a mesmo termo utilizado para o caraná (a planta) e o telhado da casa. Pode ser que seja tal associação (ou indistinção) aquilo que, de certa forma, impeça que sejam prontamente adotados os telhados de zinco; abandonando-se a palha e a paixuba, deixariam de ser habitações propriamente humanas. A única casa da aldeia Cidadezinha que possuía telhado de zinco, obtido junto ao prefeito de Tapauá, cujo dono havia falecido semanas antes de iniciarmos nosso trabalho de campo, apresentava um telhado de metal, mas com uma parte feita de palha. A falta de material, usada como justificativa pelas outras pessoas para o hibridismo, não faz jus ao fato de que a casa era muito maior que a dos outros moradores, provavelmente aumentada ao ponto de ser necessária a inclusão da palha, situada estrategicamente na parte do edifício em que, posteriormente, foi erguida uma casa/cozinha independente com cobertura de palha. Fotos recentes de aldeias do Xeruã (Fanzeres s/d) mostram que, apesar de muitas já terem chão de tabua, nenhuma parece ter sido construída, com exceção da escola, do posto de saúde e do local de criação dos porcos, com telhas de metal.

Vale notar que a paixuba poderia não ser um material tradicionalmente usado nas construções, mas agora é delas indissociável. Uma narrativa indica que, quando um professor (ainda vivo) resolveu fazer uma casa redonda, tal como seriam antigamente, ele continuou a usar paixuba no lugar de cipó, material originalmente empregado segundo alguns velhos, para amarrar as folhas de caraná. Ele adaptou o material das habitações atuais para fazer uma tradicional, isto é, dissociou forma e conteúdo, criou um formato antigo, mas com os elementos que compõem uma casa propriamente humana na atualidade. Mesmo que o uso da paixuba tenha sido incorporado a partir das experiências interétnicas, a ela, agora, faz parte do modelo mínimo ideal ${ }^{66}$ de residência humana.

Essa incorporação de elementos externos, que passam a ser fundamentais, não fugiria do padrão Deni de relação com os saberes da alteridade. O conhecimento é tido como algo cuja origem está fora, são sempre os Outros que sabem mais, o que já se coloca desde a perda de Manaus. Embora “cultura" seja já um termo conhecido e incorporado ao idioma deni, a sua conservação não é colocada pela cultura deni. Não se apropria, tal como os Gorotire, de "poderes e produtos [nas relações interétnicas] tendo

\footnotetext{
${ }^{66}$ Até mesmo na construção das sepulturas elas são utilizadas. Para enterrarem os mortos, os Deni cavam uma cova retangular, dentro do qual constroem uma espécie de casa onde armam a rede do falecido e cobrem o telhado, feito a partir de pedaços do telhado reaproveitado da casa do morto segundo nossas observações, com terra. Em cima de tudo é construída uma nova casa/telhado totalmente fechada (telhado que chega até o chão) com ripas de paixuba e folhas caraná fabricadas algum tempo após o sepultamento.
} 
em vista a reprodução de sua própria 'cultura'." (Sahlins 1997: 125). A "cultura" parece, antes, ser uma preocupação percebida como sendo dos brancos, já que não era raro ouvirmos que o forró, tocado quase o dia todo nos gravadores, não era de sua cultura, mas uma determinada música, que eles não eram mais capazes de cantar (ao menos os homens jovens adultos não conseguiram lembrar a sequência quando tentaram), faria parte da "cultura".

A capacidade de apreender os saberes da alteridade está diretamente relacionada com a melhora da condição humana; não apenas aquilo que venha do branco, já que, por exemplo, uma compilação de remédios da mata "tradicionais", que, a pedido de um dos professores, deveríamos transformar em apostila, era, em parte, de origem Kanamari. Não era raro que, durante a pesquisa de campo, uma caminhada na mata com um dos velhos que habitou no Xeruã fosse interrompida pela apresentação de uma planta medicinal muito potente, ensinada por um xamã Kanamari. Os poderes estão no cosmos e podem ser obtidos da mesma forma como fazem os xamãs. A obtenção dos conhecimentos disponíveis no cosmos é o ponto fundamental, tendo o saber/conhecer (_navatu) e o criar/inventar/fazer/construir (_[ka]navatu) a mesma raiz verbal na língua deni.

Se há algo genuinamente da cultura e "cultura" Deni, isto é a língua, o que já está colocado de forma evidente nas narrativas sobre Tamaku e Kira. Ao reiniciar o povoamento do mundo, são muitos tipos diferentes de gente que surgem, marcados pela diferença de idioma e também dos diferentes locais para moradia. De certa forma, todos são frutos de um mesmo substrato material (a lagarta ou poraquê) e criados da mesma maneira, pela regurgitação de pedaços de lagarta (ou poraquê), mas eles emergiram com idiomas diversos e foram estabelecidos em diferentes localidades. A intenção era que todos fossem humanos da mesma forma, mas isso não ocorreu, a diferença se inseriu à revelia do desejo dos heróis e se manifestava através da voz, o que leva a sua organização diferenciada no espaço.

Trata-se, por um lado, de estabelecer uma relação de identidade, os humanos são feitos a partir do mesmo material e através da mesma ação e, por outro, estabelecer diferenças, são dois irmãos diferentes que criam os tipos humanos, isto é, há uma grande divisão em dois e, também, a cada saída não se repete os tipos anteriores. Há, por um lado, identidade, mas, por outro, diferença. As versões variam na classificação dos que surgem, algumas se limitam a dizer que Kira vomitou um povo com idioma 
diferente, depois outro, outro, outro ${ }^{67}$; e Tamaku aqueles cujas línguas eram inteligíveis, podendo inclusive incluir os Kulina entre estes. No Xeruã, Kira vomita 100 vezes, a cada uma delas saindo uma população indígena com uma língua diferente, "Kanamari, Kulina e muitos outros povos indígenas" (Sass 2004: 19), Tamaku, por sua vez, produziu as diferentes subdivisões internas. Enquanto criava os humanos, ele "vomitou 16 vezes, e saíram os Deni: Hava Deni, Katu Deni, Varasha Deni, Tamakuri Deni, Bukure Deni, Makhuvi Deni, Avamakhu Deni, Upanava Deni, Minu Deni, Dima Deni, Kuniva Deni, Veshe Deni, Tanu Deni, Shivaku Deni, Kama Deni e Zumahi Deni." (Sass 2004: 19). Alguns, dentre os homens do Cuniuá, colocam Kira como produtor dos brancos, com suas diferentes línguas, e Tamaku responsável pela criação dos diversos grupos indígenas e suas diferenças linguísticas.

Comentando sobre a posição vazia preexistente que foi ocupada pelos brancos na mitologia americana, Lévi-Strauss aponta que "a criação dos índios pelo demiurgo tornava automaticamente necessário que ele tivesse criado também os não índios" (grifo nosso 1993: 200). Muitas das versões Deni sobre o surgimento dos brancos colocam os gêmeos como criadores tanto de índios quanto de brancos. Porém, como apontamos acima, este é o momento de um surto criativo, não é por terem criado os indígenas que, necessariamente, Tamaku e Kira criariam os brancos, mas, antes, porque eles são criadores de muitas coisas, parecendo apropriado incluir os brancos entre elas, num primeiro momento. A existência de outras possibilidades narrativas no contexto deni, obviamente posteriores, pois são fruto de uma elaboração inteiramente nova, mostram que não necessariamente isto teria permanecido (ou permanecerá) da mesma forma.

Vale ressaltar que, sejam quais forem as populações emergentes do interior dos heróis, os Deni são, invariavelmente, situados na última aparição, ou seja, eles são sempre os mais novos. A senioridade é tida como relacionada diretamente com o conhecimento, os velhos sabem mais que os novos, e isso em múltiplos níveis. Um xamã velho (zuphinehe hurasha ${ }^{68}$ ) sabe mais que um que iniciou as atividades há pouco tempo (zuphinehe zati), sendo o mais velho de todos tido como o mais poderoso de todos. Durante a pesquisa de campo, sempre nos indicavam o homem mais velho da aldeia como a melhor fonte de narrativas, após a sua saída da aldeia, era indicado àquele que passou a ser o de mais idade, já seu irmão gêmeo (só que mais novo) nunca era

\footnotetext{
${ }^{67}$ Em deni, quando se fala outro (uvaa), nunca se é o mesmo duplicado, quer dizer, não há identidade plena entre uma coisa e outra do mesmo tipo. Veremos isto detalhadamente no próximo capítulo.

${ }^{68}$ Zuphinehe - xamã. Hurasha - velho. Zati - novo.
} 
mencionado, sendo, inclusive, questionadas as suas capacidades narrativas. Os Deni são os que apareceram por último, logo devem ser os que sabiam menos na origem.

A inclusão da origem dos brancos no inicio da humanidade atual, opção preferida pelos mais velhos no Cuniuá, concorre com outras três narrativas até onde sabemos. A coletânea do Xeruã deixa em aberto a questão, já que não inclui os não indígenas nos eventos desencadeamos por Tamaku e Kira e nem fornece algum mito que os mencionem. Assim, é possível que, num primeiro momento, os Deni tenham incluído simplesmente os elementos novos do mundo no esquema pré-existente. Se eles existem, então eles estão aqui desde o principio.

Uma das versões de mitos de origem dos brancos obtidas remete também a Tamaku e Kira, tendo sido enunciada em português por um dos professores que a lia a partir do seu caderno, o que tomamos inicialmente como uma das narrativas inventadas para conversarmos a respeito e estudar o português. Ela, contudo, corresponde a uma reelaboração do episódio dos coquinhos das palmeiras presente no texto acima. Quando os coquinhos caíram no chão, sobram poucos para formarem as populações de Tamaku, apenas dois feitos a partir de três caroços; já quando Kira derrubou, o cacho bateu nas costas de Tamaku e muitos povos se espalharam. Depois, Tamaku disse para cada grupo onde deveria ficar, e que eles deveriam se espalhar pelo mundo. $\mathrm{O}$ narrador ressaltou que ele estava falando em português, então eram os brancos que eles estavam sendo criando.

Devemos considerar duas coisas: primeiro, no Xeruã (Sass 2004), o episódio dos coquinhos resulta na criação dos bichos de pé; segundo, esse narrador, como mencionou em ocasiões posteriores, era familiarizado com uma coletânea de mitos Kanamari em que aparece a história de Tamah e Kirak, na qual os Kanamari e os outros indígenas são formados a partir de coquinhos. Alguns apontam que os Kanamari são misturados com os brancos, assim o narrador escolheu reelaborar um episódio de Tamaku e Kira a partir de uma versão que daria conta do surgimento de quase-brancos. A identificação dos personagens de ambas as histórias, reforçada pelo surgimento de um peixe a partir de um pedaço do corpo de Kirak cortado por Tamah (seu pênis vira o peixe jeju), torna possível explicar a um branco (o antropólogo) sua origem, sem fugir a lógica de Tamaku e Kira. 
As outras histórias concernentes ao surgimento dos brancos seguem outra via, relacionando os brancos ao universo do xamanismo. Uma delas, que na verdade foi apresentada por um mesmo narrador em duas narrativas diferentes, aponta o surgimento dos brancos a partir do arabani (pedra-feitiço do xamã) misturado com a água. Para entender as duas variantes que ele apresenta, de forma apropriada, seria necessário considerar sua história de vida, o que não caberia aqui. Ressaltamos, contudo, que além da presença de "portugueses",69, que não eram brancos e sim índios, Jerusalém, uma chuva de 40 dias que causa um dilúvio, aparecem alguns elementos (como o trabalho na seringa, o comércio e o patrão), que estão presentes na outra possibilidade de surgimento dos brancos. Voltamos, assim, ao que dissemos acima, ao explicar para um não indígena sobre sua origem, o que se faz é compor um discurso em que se aciona o que seria o próprio conhecido dos brancos acerca de seu surgimento. Elas não são apenas "narração sobre os brancos, mas sobretudo para os brancos" (grifo do autor Saez 2005).

A última história que aborda a questão do surgimento dos brancos no tempo anterior ao presente é a que trata de Tahama. Ela não possui ampla distribuição, sendo seu conhecido restrito a algumas pessoas ${ }^{70}$, todas com menos do que 50-60 anos, tendo uma delas apontado que teria apreendido essa história no Xeruã. Nela os brancos não são criados a partir de um elemento, seu surgimento é fruto de uma transformação humana, não um humano qualquer, mas é um xamã que se metamorfoseia em kariva. A associação entre os brancos e os xamãs na sociocosmologia Deni já foi explorada por Azevedo (2007), mas antes de considerarmos as aproximações explicitadas por essa autora, vejamos os eventos que envolvem Tahama.

\footnotetext{
${ }^{69}$ Nela os portugueses aparecem como espécies de heróis culturais, ensinando a fazer roçado, comprar e vender, eles inventam também o trabalho.

${ }^{70}$ Azevedo (2007) fornece uma versão dessa narrativa, fornecida por um senhor que atualmente habita na aldeia Sikuriha.
} 


\section{Tahama o primeiro kariva.}

Havia uma aldeia em que não existia o branco. Um pajé chamado Tahama virou para o seu cunhado ${ }^{71}$ e disse:

- Você fica aqui trabalhando seringa. Eu vou descer o igarapé, vai passar uma lua, outra lua, outra, outra ${ }^{72}$ eu vou voltar fazendo muito barulho. Vocês ficam escutando que vão me ouvir.

Tahama pegou casca de jutai ${ }^{73}$ e desceu pelo rio. Ele parou algum tempo em uma cidade.

Os outros ficaram cortando seringa, juntaram uma grande quantidade. Um dia começaram a escutar um barulho vindo rio abaixo. Passou algum tempo e conseguiram ver um barco grande subindo, era um barco a vapor. Tahama parou na colocação em que tinha deixado o cunhado trabalhando.

Ele não falava mais a língua deni, só sabia o português. Ele tinha muitos fregueses e mercadoria. Vendeu para o cunhado dele, embarcou os produtos e deixou as mercadorias. Ele foi embora e nunca mais voltou.

As variações desta curta narração que obtivemos corresponderiam, antes, a comentários adicionais sobre os acontecimentos do que mudanças no conteúdo. Um menciona que, naquele tempo, a faca para cortar seringa era diferente; outro que ele esqueceu o idioma deni porque rasparam sua língua; outro que o barco usado naquela época era movido a vapor. Na simplicidade dos dois episódios abre-se a possibilidade de que cada narrador faça comentários a partir de suas próprias reflexões, quase nada é formulado, o próprio evento central do mito passa-se fora de cena. A metamorfose, tão presente em outros relatos, apresenta-se como inefável aqui.

Apenas a raspagem da língua, pela ação de agentes que não participam da narrativa, acarretando o esquecimento do idioma, surge como referência da mudança de

\footnotetext{
${ }^{71}$ Algumas versões apontam que ele fala para seus fregueses/seguidores/liderados/funcionários, pelo uso do termo kepei. Este termo é aplicado para indicar as pessoas que se relacionam com um chefe ou patrão, tanto indígena quanto não, "seu pessoal" na tradução mais usualmente utilizada por eles mesmos.

724 meses segundo alguns, 5 segundos outros.

${ }^{73}$ Mapuva, a canoa formada de casca de árvore. Era o veículo originalmente usado pelos Deni para o transporte fluvial. As versões variam quanto ao modo usado para a descida do rio, Azevedo (2007) aponta que foi uma flecha enfeitiçada, outros que eram três pedaços de troncos amarrados com cipó, um que foi o veículo que o xamã usa para viajar pelo cosmos.
} 
estado. Isto, contudo, é incomum ao modo com que geralmente esta ocorre em outros relatos. As narrativas que abordam a transformações dos humanos apontam que os humanos perdem a humanidade, quase sempre, quando gritam como o animal ou espírito que irão se tornar, é este ato de fala que os torna outra coisa, e não qualquer ação primeira sobre seus corpos, o que quase sempre ocorre após a metamorfose.

Os marcadores temporais presentes nesta narrativa funcionam de maneira semelhante aqueles que procuram situar alguns acontecimentos no passado remoto, na época em que não havia roçado, não havia determinado ritual, etc.. Eles situam os eventos num tempo recuado, não vivenciado pelos vivos ou mesmo por mortos recentes, mas que não se confunde com o tempo dos imabute, no qual há uma diferença qualitativa em relação ao presente. Essa narrativa difere dos discursos a respeito do surgimento dos não indígenas na região em que agora habitam os Deni e cujos participantes são lembrados como estando de certa maneira conectados às pessoas ainda vivas ou recém-falecidas. O dito e o não dito são igualmente importantes para entender o que está sendo colocado.

A história aborda o aparecimento dos kariva, mas os próprios indígenas já estavam inseridos na extração da seringa. Não se trata de estabelecer um momento em que não havia brancos e seus objetos, mas, ao contrário, o extrativismo e as ferramentas são pressupostos da condição humana anterior ao surgimento dos não indígenas. Longe de ser percebida como uma influencia que desorganizou a vida tradicional, tal como apontou Kroemer (1985), sua existência precede àqueles que nós, euro-americanos, percebemos como sendo seus agentes causadores. Os brancos não criaram a extração da seringa, sendo, apenas, aqueles que a colocaram em movimento no cosmos, isto é, que realizam uma espécie de xamanismo.

O xamã, um mediador/transportador, ao transformar-se em branco, estabelece o que todos sabem, as mercadorias sobem o rio e os produtos da mata descem. Uma das características mais salientes do xamanismo deni parece ser o transporte de espíritos e arabani (a pedra-feitiço). Ele resgata os espíritos que tenham sido levados dos corpos humanos e os acompanha novamente para a aldeia; ele transporta espíritos de seres para dentro das mulheres para engravidarem; transporta frutas do céu para a terra; filhos de animais de caça para atrair os adultos para as proximidades; os mortos para o céu, etc.. Na narrativa de Tahama, um xamã se transforma em branco e passa a ter acesso às regiões do cosmos em que elas se encontram. 
O sentido das mercadorias e produtos, estabelecido com Tahama, é invariável na região, tanto para os indígenas quanto para os brancos, o que desce em direção a Manaus e o que sobe para a região são sempre os mesmos tipos de coisas. Os patrões e seus barcos, assim como o xamã e seu veículo ${ }^{74}$, empreendem as viagens das quais retornam com as mercadorias. Esta direção das coisas é reproduzida até o limite do conhecimento do cosmos, refletindo uma lógica em que alguém fornece os produtos e recebe mercadorias: dos Deni para um comerciante, deste para a balsa que segue para Manaus, de Manaus para o resto do mundo. Os brancos não aparecem como os produtores de mercadorias, o que se observa é que, alguns dentre eles, se inserem na cadeia da mesma forma que os indígenas, já outros, os patrões, são capazes de obtê-las rio abaixo.

Alguns Deni viajaram, durante muitos anos, junto aos comerciantes que atuavam na região pela década de 1960-1980. Um dos moradores da aldeia Cidadezinha foi até o Peru pelo Juruá e muitos outros até Manaus (ou mesmo Santarém). As descrições das viagens mantêm a ideia de que os produtos descem os rios e as mercadorias sobem. Um dos que foi até Santarém acrescentou que lá acontecia o mesmo fenômeno, os produtos da mata e dos rios desciam o rio Amazonas e as mercadorias subiam o rio até o porto de Manaus. É um esquema cosmológico que é, em certa medida, compartilhado por índios e brancos das vilas e colocações do Purus.

A não elaboração sobre a transformação de Tahama em branco/patrão é condizente com a falta de conhecimento quanto à origem das mercadorias. Se os indígenas são incapazes de fazê-las, o mesmo pode ser dito sobre a maioria dos brancos, que, não sendo comerciantes, são obrigados a entrar no circuito de trocas, tal como os indígenas. Alguns são capazes de mover-se até as regiões do cosmos em que elas estão disponíveis, como fazem os xamãs, cujo conhecimento necessário para isso, somente eles possuem ${ }^{75}$. Não se relata sobre o que aconteceu ou sobre o local em que estão as mercadorias, pois, apenas os próprios brancos, e possivelmente só os patrões, é que têm possibilidade de fazê-lo apropriadamente. Ou, então, voltamos ao problema de que,

\footnotetext{
${ }^{74}$ Nenhum xamã se mostrou disposto a explicar sobre esse veículo, mas parece que ele possui uma espécie de barco/avião que usa nas viagens pelo cosmos. Ou a ideia que as pessoas comuns possuem está relacionada ao que é colocado em Tamaku e Kira, um continente para transporte de espíritos.

${ }^{75}$ Os Deni não comentam sobre um grande numero de assuntos que apontam ser de conhecimento exclusivo dos xamãs. Podem fornecer descrições genéricas sobre o cosmos, mas quase sempre apontam que foi um xamã que narrou a informação. Qualquer pedido por uma elaboração adicional acaba encontrando um obstáculo, já que ninguém está disposto a fazer comentários, para o antropólogo, sobre regiões do cosmos que desconhece pessoalmente.
} 
sendo um domínio de conhecimento dos brancos, afinal, são eles que trazem as mercadorias em suas viagens, só se falaria sobre isso a um deles (o antropólogo) se soubessem as nossas narrativas sobre a origem dos bens.

É possível que a maioria dos primeiros discursos a que os Deni tiveram contato indicasse sempre a origem distante das mercadorias. Primeiro, por intermédio de outros indígenas, elas vinham dos brancos ou de alguma terceira população com a qual eles

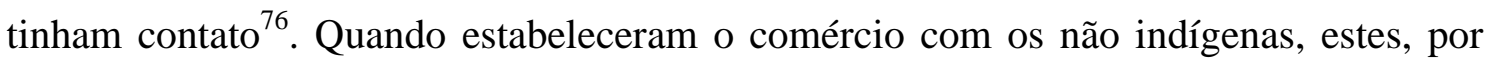
sua vez, deveriam apontar Manaus como sua origem, nos dias de hoje são as balsas que vem de Manaus responsáveis pelo seu fluxo para a região... Até mesmo as roupas e outros bens recebidos em grande quantidade pela ação de uma missionária, a "Dona Paula", cujas doações, mencionam alguns sem serem perguntados, foram compradas por ela no Peru (segundo ela mesma) ou, exclusivamente para as roupas, conseguidas com os amerikanu. Amerikanu que, como já dissemos, correspondem aos brancos que não falam português ou espanhol e habitam terras distantes onde, também, nasceu a "Dona Paula".

Nas duas versões mais difundidas sobre as origens cósmicas dos não indígenas aparecem como pressupostas as ferramentas. Seja Sinukari usando um machado para derrubar as pedras do céu, seja o cunhado de Tahama extraindo a seringa, tudo se passa como se as ferramentas fossem um dado do cosmos, seu aparecimento não se torna ponto de reflexão. Alguns apontam que os machados sempre existiram, usando como argumento o fato de que sem eles não seria possível derrubar as árvores para fazerem os roçados $^{77}$. Sem fornecerem uma alternativa aos modelos atuais, os machados antes eram obtidos através da predação ou da guerra conta aqueles que os possuíam.

Um senhor fez referências aos terçados que os brancos deixavam amarrados em árvores e que eram apropriados pelos indígenas, que utilizavam pedras de igarapé para amolá-los. Não há maiores informações sobre isto, sendo impossível dizer se este seria o momento em que as frentes de atração do SPI haviam contatado os Deni. Parece haver

\footnotetext{
${ }^{76}$ Dados de Coutinho (1862) apontam que existia uma grande rede de trocas na região no século XIX, mas se limita a listar o local de produção e o sentido imediato das trocas. Por exemplo, os Katawixi preparavam "tinta do carajurú" que trocam por instrumento de pesca dos Paumari e enfeites de penas dos Apurinã.

${ }^{77}$ É possível que os Deni não praticassem a agricultura em algum momento do seu passado, mas há uma narrativa que aponta o surgimento dos roçados a partir de uma mulher-bomba que causa um grande incêndio. Interessante notar que para os Deni um incêndio esta relacionado com o surgimento das plantas cultivadas, já entre os Kulina (Silva Kanaú 1983) um grande incêndio se associa a criação da humanidade atual.
} 
um silêncio quanto a isto, haja visto que os machados não aparecem nas narrativas de que dispomos sobre o tempo das guerras e os roubos teriam acontecido antes do momento de pacificação. Esta é atribuída ao contato com os brancos, quando deixaram de lado as disposições assassinas tão presente nas narrativas míticas e que, quando enunciadas, são, muitas vezes, acompanhadas pelo comentário de que, antes, os Deni queriam matar tudo o que encontravam.

Houve apenas um enunciado a respeito da possibilidade da abertura de roçados em uma época em que não haviam machados. O narrador afirmava que, segundo seu pai, antes, para derrubar as arvores de um roçado, amarrava-se um cipó duro, como um cabo de aço utilizado em barcos, em volta de todas elas. Escolhiam, então, a maior de todas para ser derrubada. Quando ela caia, o cabo era esticado e cortava todas as outras. Até onde vão nossos conhecimentos, não há menções a existência anterior de machados de pedra ou osso ${ }^{78}$ como possuindo a mesma função dos atuais, o que difere do caso das facas, que vieram a substituir os dentes de paca como objetos cortantes. Do roubo dos machados, às trocas e ao comércio, a história Deni é aquela que os aproxima das fontes dos bens que sempre estiveram no cosmos, mas que não são acessíveis a qualquer um.

A própria geografia parece ser menos fixada que a existência desses elementos desde um tempo descolado do presente. Embora não tenha sido relacionada à Tahama, um dos senhores de mais de 60 anos chamou nossa atenção para a ausência primeira de rios, que só passaram a existir quando um barco navegou por um igarapé, causando seu alargamento e transformação em rio. Originalmente, os Deni habitavam em regiões de terra firme, no alto de igarapés, afastados dos cursos dos rios, e as migrações ainda presentes na memória, e que envolveram a travessia de alguns rios da região, são aquelas que ocorrem em um tempo posterior a ter sido restabelecido o contato com os brancos.

As histórias de que tratamos até agora abordam, entre outros temas, as origens dos não indígenas e, também, a separação que se estabeleceu entre estes e os humanos propriamente humanos (os Deni). Seja Tamaku designando uma aldeia afastada, ou Tahama descendo o rio em seu barco e nunca mais retornando, os brancos surgem no

\footnotetext{
${ }^{78} \mathrm{O}$ machado na língua deni (bari) não parece possuir outro referencial que o machado de ferro, já o martelo, embora seja comumente nomeado por uma corruptela do termo em português, é avi khuburi, onde avi (anta) e khuburi (joelho dele), isto é, o martelo é o joelho de anta. Azevedo, em uma lista de palavras associando algumas mercadorias e os termos nativos, aponta que bari seria uma "palavra usada antigamente para referir-se a um machado de pedra" (2007: 89).
} 
cosmos e logo saem de cena. Nos outros momentos em que são tematizados, mesmo que com certo tempero mitológico, os eventos narrados estão situados nas proximidades das pessoas vivas, é um passado que possui a mesma qualidade do tempo presente (metha, methamani). Os acontecimentos mais antigos, após a retomada do contato com os brancos, são situados em regiões em que teriam vivido os avôs dos velhos ainda vivos ou recém-falecidos. Aqueles que se constituem em narrativas propriamente ditas se situam na época em que viviam os pais dos velhos, ou mesmo na infância destes.

\section{3 - Histórias Deni do contato com os brancos}

Abordamos, aqui, a questão dos contatos com os brancos em épocas relativamente recentes. Trataremos daquilo que se situa, de certa forma, no limite do tempo atual. As informações são geralmente atribuídas a uma fonte próxima, embora já falecida. Assim, a mãe ou o pai de um dos velhos, ou um ancião que algum dos adultos conheceu em vida, transmitiram aos mais jovens aquilo que teriam vivenciado ou o discurso de algum dos seus contemporâneos. As narrativas sobre esses eventos variam, mas não se tratam, apenas, de versões sobre os mesmos acontecimentos, são, antes, variações sobre acontecimentos que eram apreendidos e enunciados a partir de regiões diferentes. Não há uma grande narrativa Deni sobre o contato, mas vários fragmentos.

A apresentação dos momentos mais recuados na história que expomos possui uma distorção inevitável. Tivemos maior contato com pessoas da aldeia Cidadezinha que são descendentes de ex-moradores de determinada região, o que resulta numa história que parte de eventos que lá transcorreram ou que são vistos a partir deste local. É possível que, nesse momento, as aldeias de outras regiões fossem ainda parte dos Outros, o que não ocorre atualmente com a visão de que os Deni são apenas um "Nós", logo suas versões não foram incluídas na cadeia de transmissão que acessamos. Assim, dispomos de informações sobre os acontecimentos que foram vivenciados por ascendentes de boa parte dos moradores das aldeias Cidadezinha e Marrecão e muitas outras pessoas espalhadas pelas diferentes comunidades, mas que não correspondem a metade do total de falantes do idioma.

No que diz respeito aos eventos de um passado remoto de contato com os brancos, não fomos capazes de observar nenhum momento em que eles foram espontaneamente enunciados. Muitas vezes, contudo, a partir de nossa investigação, 
iniciavam-se discussões sobre os acontecimentos do passado, não sendo incomum a realização de consultas aos velhos presentes nas casas próximas, ou mesmo distantes. Não foram realizados registros sonoros desses momentos, então não podemos comentálos apropriadamente, já que ao final sempre surgia uma versão que era fornecida para ser escrita, mas não gravada. Foi possível apreender, entretanto, que muitas vezes o debate procurava esclarecer o que alguém, já falecido há algum tempo, havia dito. Quando os eventos tinham sido vivenciados e transmitidos por um dos pais, nunca se procurava consultar terceiros e dificilmente surgia um debate.

O contato dos Deni com os não indígenas foi, primeiro, restabelecido na região do rio Pauini ${ }^{79}$, um afluente do Purus ${ }^{80}$, acima da cidade de Lábrea. Através dele obtinham ferramentas e espingardas ${ }^{81}$, seja pela troca ou pelo roubo. Os kariva ainda se mantinham afastados, não há menção ao convívio com eles ${ }^{82}$, apenas aos bens que deles se obtinha. Trata-se de um tempo em processo de esquecimento ${ }^{83}$, surgindo de forma tímida e não se constituindo, em grande medida, como uma narrativa coesa. São comentários esparsos de algo que não encontra lugar na memória, surgidos a partir dos questionamentos repetitivos do antropólogo.

A identificação do Pauini, durante nossa pesquisa, como o local do primeiro encontro pode ter sido influenciada pelo reconhecimento, por parte dos Deni, de que os Camadeni, uma população indígena do rio Mamoria, no município de Pauini, seriam

\footnotetext{
${ }^{79} \mathrm{O}$ mapa de Chandless (1866), que viajou pelo Purus entre 1864 e 1865, indica que havia uma migração de índios Jamamadi, que se localizavam entre os rios Pauini e o Mamoria-Grande até o Cuniuá, o qual cruzavam para chegar até o Tapauá. Jamamadi nas línguas arawá próximas ao deni, seria propriamente zama-madi, quer dizer, povo da mata, isto é, pessoas habitantes da terra firme, tal como seriam os próprios Deni nessa época. Steer, contudo, aponta outra etimologia para o termo, segundo ele Jamamadi "parece provir do paumari e significar 'homens selvagens' (jûwã-mãgî)" (Steer 1949: 214). Coutinho (1863) aponta a existência de três aldeias Mamorys no rio Cuniuá e de quatro aldeias Katukina, uma Paumari e duas de Cipós e Katawixi no rio Tapauá. Nos dias de hoje são conhecidos por Jamamadi populações muito diferentes, algumas que falam línguas bem próximas ao deni e kulina e outras que falam línguas semelhante a dos Jarawara e Banawá (Dienst 2008).

${ }^{80}$ Os documentos históricos indicam que os rios Purus e Juruá já eram explorados em meados do século XVIII, passando a ser ocupado por não indígenas no XIX. Gonçalves (1904) aponta que pelo início do século XX o Purus era o rio de maior importância econômica para o Amazonas, seguido pelo Juruá. Para um histórico da conquista do rio Purus pelos não indígenas veja Kroemer (1985), Ferrarini (1980, 2009), Weber (1998), Lazarin (1981), Cardoso (2011), Cunha (2003) e Jaramillo (2004). Para o Juruá ver Mendonça (1989), Castello Branco (1950, 1958) e Derickx \& Trasferetti (1992).

${ }^{81}$ Mencionam que na verdade eram "rifles" e não os modelos de espingarda atuais.

${ }^{82}$ A única menção ao convívio é a de que uma das moradoras mais velhas da aldeia Cidadezinha, com uns 70-75 anos em 2012, era filha de um branco, do qual só se sabe o nome da língua deni e que não moraria perto da aldeia. Koop \& Lingenfelter (1983) apontam que nessa época (aproximadamente 1930) dois patrões compravam borracha e couro dos Deni, um deles teria mantido relações sexuais com uma das mulheres, resultando no nascimento desta senhora.

${ }^{83}$ Nossa reflexão sobre memória é devedora de uma comunicação de Ana Cecilia Venci Bueno. Aguardamos o desenvolvimento de suas ideias em sua futura tese de doutorado.
} 
descendentes de um dos grupos Deni do passado. Parece que, o conhecimento sobre os Camadeni ocorreu no contexto do movimento político do médio Purus, durante o qual eles estabeleceram contato. Em 2011, os Camadani saíram de suas aldeias por terra e seguiram até o rio Cuniuá, realizando uma viagem que teria sido, segundo os Deni, uma tentativa de localizar uma aldeia Camadeni que ainda estaria sem contato.

O resultado da expedição foi a localização de uma senhora, moradora da aldeia Samauma, que, sendo Deni hoje em dia, seria descendente do grupo Camadeni. A memória, tal como aponta Jolly (2002), é mobilizada num contexto do presente em que ligações passadas, presentes e futuras são ativadas no discurso. E, com efeito, após esse encontro, e o estabelecimento de uma origem comum, foi realizado o casamento entre um Deni e uma Camadeni. Os Deni, que condenam os casamentos interétnicos, embora existam alguns, estabeleceram uma identidade com os Camadeni, acessando o passado de forma (cri)ativa, o que resultou na possibilidade da realização de uniões matrimoniais.

Durante nossa pesquisa de campo, as informações obtidas sobre os eventos que teriam ocorrido no Pauini são, por um lado, influenciados pelo passado mais recuado e o presente e, por outro, pelo que se projeta como o futuro do narrador. Os jovens adultos e os recém-avôs, os mais dispostos a falar desse tempo, têm como parâmetros o tempo dos antigos, encarnado nas narrativas, durante o qual as disposições antissociais da violência eram o padrão, e o tempo presente, que teria se iniciado após a convivência com os brancos no Cuniuá, em que as disposições não agressivas passaram a ser o padrão ideal de convivência, ponto comum de todos os discursos. Mesmo que o presente seja marcado por diferenças no modo de convívio, sempre que há uma discussão, inclusive quando não ocorre qualquer ameaça nesse sentido, as pessoas, nos dias de hoje, dizem que o outro estava querendo matá-lo, ou seja, está sempre presente a possibilidade de que as disposições negativas dos antigos ressurjam. Esta visão faz com que desperte, entre os Deni que se envolvem em discussões, o desejo de mudar para outra aldeia, onde existiriam os parentes de verdade ${ }^{84}$, ou para um local isolado com sua família. Sempre que há um conflito, desponta a ideia de que é melhor ir viver entre os parentes, isto é, viver entre aqueles que se comportariam apropriadamente.

Parente é a tradução para português do termo uvibuva (forma possuída - "meus parentes"), que estaria associado ao "Nós" em suas muitas formas de conceituação. É

\footnotetext{
${ }^{84}$ São uvibuva.aride, sendo uvibuva - meus parentes e aride - de verdade, real.
} 
uma das categorias tão comuns em outros contextos etnográficos da América do Sul que, em seu limite máximo, inclui toda uma população ou aldeia, sendo que para os Deni seu limite mínimo seriam os parentes consanguíneos próximos, estando a esposa excluída deste uso. Entre os parentes as relações deveriam ser sempre boas, excluindo a violência e as más disposições, o ideal é que todos os uvibuva ("meus parentes") vivam em paz, sem qualquer tipo de guerra e/ou predação entre eles.

Talvez não seja sem razão que apenas um senhor muito velho, que nas últimas décadas passou apenas uns poucos anos morando em uma das aldeias Deni ${ }^{85}$, era o único que espontaneamente mencionava o passado de guerras no qual seu pai estaria envolvido. Os outros velhos, que ainda não se sentiriam no final de sua existência, não comentavam sobre esse tempo e, quando o faziam, não se colocavam em uma relação de parentesco com os que teriam vivenciado esses acontecimentos. A violência deste tempo é o motivo para as migrações, que fez com que os ancestrais das pessoas vivas fugissem para a região do Cuniuá, onde não existiam brancos e, provavelmente, é ela o que se coloca no esquecimento. São tempos, atualmente, condenados ao apagamento pela sua não enunciação para os mais jovens, tornando a agressividade incontrolável uma característica descolada do presente e do futuro, sendo isolada no tempo dos imabute e excluída do passado recente.

No Cuniuá, o tempo torna-se narrável novamente, não sendo mais composto por fragmentos descontínuos, como é o tempo do Pauini. Durante a pesquisa de campo era fácil obter comentários sobre os eventos ocorridos na região, sendo possível apreender diferentes versões sobre os acontecimentos e os personagens dos enunciados estão ligados aos narradores. São seus pais e avôs que estão presentes, seja participando diretamente dos eventos ou transmitindo o que foi dito pelos participantes, seus contemporâneos de idade mais avançada. Podemos perceber que, nesse tempo, há divisões entre os Deni (os pontos de vista sobre o que acontece são variáveis), mesmo que não seja possível precisar, porque de certa forma é algo negado pelos discursos que apontam geralmente a existência uma única grande aldeia. Há diferentes aldeias Deni que encontram os brancos e passam com eles a se relacionar.

\footnotetext{
${ }^{85}$ Esse senhor tinha, segundo seu registro de nascimento, 73 anos em 2012; mas é possivelmente mais velho do que foi registrado. Teria voltando a morar em uma aldeia em 2007 ou 2008, quando conseguiu uma esposa, mas a abandonou em 2010, voltando a morar com a filha na cidade de Tapauá, tendo regressado para a aldeia em meados de 2011 e abandonado novamente em dezembro de 2011.
} 
Após a saída do Pauini, alguns Deni se estabeleceram na terra firme próxima ao rio Mamoria ${ }^{86}$ e, depois de algum tempo, seguiram para a região entre os rios Cuniuá e o Xeruã (afluente do Juruá). Eles passaram por diversas aldeias/localidades, não muito distantes entre si, até que aqueles que haviam se estabelecido em um igarapé que corre para o Cuniuá receberam a noticia ${ }^{87}$ de que os brancos haviam sido encontrados no Xeruã $^{88}$. Nessa época, havia outra aldeia no alto do igarapé do Cojubim que deságua no Xeruã. Alguns dentre os moradores do igarapé do Cuniuá viajaram para o Xeruã e no retorno contaram que os brancos eram bons e possuíam muitas coisas, após o que foi estabelecida uma rota comercial, formando-se um varadouro na mata ${ }^{89}$, ainda utilizado nos dias de hoje, que era atravessado com couro e seringa num sentido e mercadorias no outro.

Eles formaram, depois, uma aldeia no igarapé do Diara, um afluente do Cuniuá, a partir da qual ocorreram migrações para a região do Cojubim, onde, alguns, passaram a trabalhar diretamente com os não indígenas ${ }^{90}$. Muitas pessoas que ficaram no Diara deslocaram-se, posteriormente, para o igarapé Kakiri/Maravilha, estando nesta aldeia a maioria dos ancestrais ou das pessoas velhas que atualmente habitam nas aldeias Cidadezinha, Marrecão, Zunamete e Volta Grande. Os moradores do Cuniuá continuaram a participar de trocas efetuadas no Xeruã, num circuito que se manteve ativo durante muitos anos, mesmo após o surgimento dos brancos no Cuniuá.

A descoberta da existência de brancos no Cuniuá tornou a relação com eles permanente, passando a ser considerada a influência que eles tiveram sobre os próprios Deni, isto é, o fim dos conflitos, que atribuem a convivência com os não indígenas. Até esse momento, não existem narrativas elaboradas e transmitidas sobre os acontecimentos que envolvem os brancos, geralmente, a inquisição do antropólogo sobre a relação com eles só tinha como resposta que eles já estavam no Pauini, ou que

\footnotetext{
${ }^{86}$ Um homem na casa dos 75-85 (nascimento aproximado em 1930-1935) relatou que seu pai participou de uma guerra no Cuniuá, e sua mãe teve um filho (nascido em 1956 segundo seu registro) após ficar viúva com um dos moradores mais velhos da aldeia Cidadezinha, atualmente com 65-70 anos (nascimento aproximado em 1935).

${ }^{87}$ Essa informação foi dada pelo avô de um dos velhos da aldeia Cidadezinha que teria se mudado para o Xeruã anteriormente a presença dos brancos nessa região.

${ }^{88}$ Uma narrativa sobre o primeiro encontro no Xeruã é reproduzida por Azevedo (2007). Ela teria se passado quando o pai do informante (este com 40-45 anos em 2012) era recém-nascido.

${ }^{89}$ Entre seus utilizadores estariam dois cunhados, cujos filhos mais velhos inda vivos tinham 60-70 anos em 2012.

${ }^{90}$ Entre eles um dos velhos da aldeia Cidadezinha (aproximadamente 60 anos em 2012), que na época era jovem. Enquanto ainda era solteiro (seu filho mais velho tem aproximadamente 40 anos) trabalhou junto com os brancos, os Kulina, Kanamari e outros pela região do Juruá.
} 
apareceram primeiro no Xeruã e compravam certos produtos (couro, seringa). As informações que apresentamos foram obtidas de forma esparsa: durante a descrição do assassinato de um xamã, mencionaram, que ele havia ido comprar uma espingarda no Xeruã; ou que o pai foi para o Xeruã, antecedendo a descrição de eventos mais recentes; ou que hoje os jovens não aguentam andar até o Xeruã, mas que na época de determinada pessoa ela enchia um paneiro de couro e seringa ia até o Cojubim e voltava com muitas mercadorias.

A partir desse momento, transcorrido durante a infância dos homens que já são bisavôs, passam a existir narrativas sobre os encontros com os brancos, tais discursos descrevem desde a primeira aparição no Cuniuá até a última visita a alguma das cidades da região. É comum encontrar alguém descrevendo algum evento, passado ou recente, que envolve os brancos, ou retransmitindo algo que eles tenham dito. Estes enunciados são realizados de uma forma na qual as falas em português são reproduzidas pelo narrador, isto é, há a repetição do que os personagens disseram em português, seguida pela tradução para a língua deni. O momento em que retomaram o contato com os kariva é aquele em que a sua língua vai progressivamente sendo internalizada nas aldeias, mas não se trata de substituir o idioma deni pelo português, muito pelo contrário, pois ocorre exatamente o inverso, o português é que está se perdendo (ou estaria se não fosse o aumento progressivo das viagens às cidades da região). A fluência no português é diretamente proporcional à idade do falante, os mais velhos sabendo mais do que os mais novos ${ }^{91}$.

Voltaremos a isto na sequência, depois de apresentar como é relatado o primeiro encontro com os kariva no Cuniuá. A partir deste momento, posterior às relações no Pauini, Mamoria e Xeruã, os brancos passam a estar em toda parte, quadro que começa a se alterar com a crise da sorva nos anos 1980 e a demarcação das terras indígenas na região nos anos 1990-2000, que resultam na migração dos não indígenas para localidades distantes no Cuniuá. Durante esse processo, vários eventos são apreendidos em discursos que passaram a ser transmitidos àqueles que não os vivenciaram. Os que aparentam ter maior difusão são os que envolvem os patrões ${ }^{92}$, o que já aparece marcado na narrativa sobre o primeiro encontro.

\footnotetext{
${ }^{91}$ Sendo exceções os agentes de saúde e professores, que sabem menos que os velhos (embora tenha maior domínio semântico sobre alguns assuntos) e mais que seus coetâneos.

92 Alguns "patrões" eram extrativistas que, pela exploração da mão de obra indígena, conseguiram ascender economicamente e se tornarem efetivamente comerciantes.
} 


\section{Manel Moco e Zé Alexandre ${ }^{93}$}

Alguns Deni saíram para caçar perto do igarapé. José e Pedro ${ }^{94}$ encontraram uma canoa parada na beira. Um dos homens viu o rastro. Voltou para a aldeia e disse:

- Tem kariva aqui, eles vão matar a gente.

João foi até o local procurar o branco. Chegou perto de Moco (o branco, "moco" quer dizer surdo no português regional) que estava tirando lenha e se escondeu. Moco viu Pedro pegar sua espingarda para matá-lo. Ao perceber o que se passava ele fugiu correndo para pegar a sua espingarda.

- Eu tenho espingarda. Vou matar vocês - Disse Moco.

José pegou a flecha com veneno e apontou para Moco que assustado disse:

- Eu sou bom. Não me mata.

- Está bem.

Voltaram. Moco levou José para beira do rio, onde encontraram Zé Alexandre, irmão de Moco. Todos colocaram as armas de lado e conversaram. Os brancos deram roupa para os Deni e todos voltaram para suas casas. José e Maria $^{95}$ foram então trabalhar sorva.

Moco e Zé Alexandre contaram que haviam índios bravos no Cuniuá. Falaram para Chico Severo.

\footnotetext{
${ }^{93}$ Há muitas versões desta narrativa, quer dizer, há variações entre as versões que assumem o mesmo ponto de vista, isto é, são narradas a partir da mesma aldeia. Os personagens indígenas variam, bem como as ações. O texto que apresentamos foi construído a partir da fala do homem mais velho da aldeia Cidadezinha e apresenta os elementos mais comuns das outras versões. Segundo sua fala, ele estava presente nos momentos em que a presença dos brancos é percebida pela primeira vez e também quando chega o barco de Chico Severo. José seria o seu sogro, cujas falas instruem seu genro a ficar escondido. Temos, também, versões de parte desses eventos a partir de pessoas habitantes de outras localidades.

${ }^{94}$ Os nomes dos indígenas que aparecem em português não correspondem aos que surgiram durante as narrações. Os personagens que desempenham as ações variam com os relatos, por exemplo, o nome da pessoa que em uma das versões pegou um arco é o mesmo que em outra pegou uma espingarda. Apenas os nomes dos brancos foram mantidos, havendo apenas variações sobre Moco, que seria Manel Moco para alguns, e Manel Alexandre para um Deni que com ele conviveu.

${ }_{95}$ Maria, Kavarini em algumas versões, é uma mulher que, pelo que dizem, já dominava o português. Em uma das versões fornecidas por Azevedo (2007), que só aborda a chegada de Chico Severo, ela é a única que não se esconde com a aproximação do barco, sendo a primeira a embarcar nele. Ela disse para Chico Severo que os Deni eram mansos, que não eram valentes e por isso eles não deviam ser mortos.
} 
- Tem caboclo bravo lá no alto Cuniuá, acima do igarapé preto. Eles são bons.

Chico Severo comprou muito terçado, roupa, espingarda, sal e açúcar do Raimundo Batista ${ }^{96}$, seu patrão. Ele subiu o rio com o Kahamidi, seu primeiro barco. As mulheres não quiseram, estavam com medo dos indígenas, foram só os homens, deixaram suas esposas. Viajaram por três dias.

Himanavi era o chefe, ele estava moqueando piranhas e escutou o barulho do motor chegando. José disse para o pessoal ficar escondido. Himanavi, Kazuza, José e João foram, os outros se esconderam. Kau, que era xamã, tinha ficado escondido no mato e estava com sua espingarda.

O barco parou na boca do igarapé e os quatro Deni foram até o barco. O pessoal do Chico Severo estava armado segurando suas espingardas. Ele disse para seus fregueses:

- Não atire. Eles são caboclos bons.

Himanavi comprou algumas coisas: açúcar, panela... Os Deni compraram tudo que tinha no barco. Levaram o Velho Chagas, o Chico Severo, o Zé Matias e o Zé Alexandre até a aldeia. O Sotero ficou esperando no barco. Chico Severo ficou dormindo dois dias na aldeia. Ele disse:

- Himanavi, agora eu compro couro de onça, caititu, anta, de todos os bichos de caça.

Chico Severo, primeiro, comprava muita coisa. Ele desceu o rio novamente para comprar mercadorias e os Deni começaram a trabalhar para ele. Os Deni já sabiam um pouco de português que tinham aprendido no Xeruã ${ }^{97}$, porque começaram a comprar primeiro lá. O Himanavi já usava roupas que tinha conseguido no Xerua ${ }^{98}$.

\footnotetext{
${ }^{96}$ Ele era irmão do Arivan Junior e foi morto em Manaus. Sempre tinha muita mercadoria.

${ }^{97}$ Alguns apontam que aprenderam o português no Pauini ou Mamoria.

${ }^{98}$ Uma das versões do primeiro encontro com os brancos no Cuniuá, fornecida por Azevedo (2007), é marcada pela afirmação de uma carência. Nessa época os Deni não conheciam açúcar, roupa, sabão... até mesmo o sal seria desconhecido.
} 
Esta narrativa apresenta, em realidade, dois momentos diferentes: o primeiro encontro com os brancos no Cuniuá e; a visita de Chico Severo, que aparece como o primeiro patrão na região e corresponde a parte mais comumente narrada. $\mathrm{O}$ ponto comum entre elas são as afirmações de que os Deni são bons, mansos, isto é, abandonaram a guerra como modo de relação com a alteridade. A alteridade, entretanto, se mantem num estágio menos propriamente humano, possuindo a disposição violenta do passado. A possibilidade de comunicação, isto é, a marcação de que algum deni já sabia o português, é o que garante a não violência do primeiro encontro e torna possível o surgimento do comércio. As versões dos primeiros encontros, tanto para o Xeruã quanto para o Cuniuá, fornecidas por Azevedo (2007) têm como ponto comum a intercomunicabilidade, mesmo quando se marca o desconhecimento anterior da existência dos brancos, a possibilidade de comunicação é dada.

Um das versões de que dispomos, sobre o primeiro momento desse encontro, salienta como a falta de comunicação poderia ter levado ao surgimento de um conflito, mas isto não é descrito a partir de um problema linguístico propriamente dito, isto é, como o desconhecimento do idioma. Nessa variante, a canoa encontrada continha alguns instrumentos para a coleta de sorva e os indígenas resolveram esperar na canoa pelo retorno dos brancos. Estes chegaram e se assustaram, pegando logo suas espingardas. Criou-se um momento de tensão no qual todos os participantes estão armados, e ele foi resolvido pelas afirmações de um dos Deni de que eles eram mansos, que não faziam guerra. Essa mensagem, contudo, não foi recebida por Moco, que era surdo, mas seus companheiros conseguiram explicar a situação para ele e todos se acalmaram. Para marcar o problema de comunicação que quase faz surgir um conflito, não se passa pela ideia de que a dificuldade estava no pouco conhecimento do português, fazendo-se uso da função surdez de Moco para tal, tudo se passa como se o resultado pacífico do encontro pressuporia um domínio da língua do Outro.

Como dissemos acima, o português foi internalizado no cotidiano Deni, mas não de forma a comprometer o idioma nativo. Não se coloca a possibilidade da mobilização do português como língua de comunicação cotidiana. Diferente do que acontece no contexto do Uaupés, onde a escolha de uma língua para comunicação vai depender dos idiomas dominados pelos participantes (Aikhenvald 2003); um Deni só recorre ao português na comunicação com um kariva. Conversando em um grupo que inclui kariva e outros indígenas eles falam português, mas retornam a língua materna quando falam 
entre si durante o curso da conversa ${ }^{99}$. Em alguns momentos se dirigem a outros indígenas e brancos em deni, mesmo quando sabem que estes não entendem o que está sendo dito.

Não há qualquer preocupação em excluir a fala do Outro do cotidiano, tal como seria o caso Xinguano (Franchetto 1993), não há um espaço e uma forma apropriada para se expressar a língua do Outro. Podemos perceber que há uma preferência pelo uso do português $^{100}$ (ou corruptelas deste) para mercadorias não essenciais, mas que possuem termos na língua, tal como o açúcar (mahuna, comumente chamado de ashuka), café (beku, chamado kape), colher (amunehe, chamado kuze). As mercadorias consideradas como essenciais são geralmente referidas pelos termos em deni, tal como kahiru (anzol), zukira (sal), maduni (linha de pesca), huhuka (faca).

Como mencionamos acima, nos discursos sobre os eventos em que participam os brancos, suas falas em português são reproduzidas em meio à narração na língua deni, sendo seguida pela tradução para a compreensão dos ouvintes. Essa circulação de falas em português e não seu uso na comunicação, bem como a frequente audição do forró nos gravadores, torna a aldeia um contexto em que o português se faz presente sem que com isso seja comprometida a língua materna. A língua é o ponto a partir do qual a paz intra-Deni teria sido construída, ou seja, sem deixarem de ser humanos, isto é, sem perderem sua língua, a presença do português sinaliza a possibilidade de não violência com os brancos.

Como aparece nas narrativas sobre os primeiros encontros no Cuniuá, é sempre um ato de fala, em português, o que põem de lado a ameaça de violência e torna possível a troca. Se os kariva ordinários podem ser pacificados apenas pela comunicação oral, o mesmo não ocorre com aqueles que seriam os patrões, que são figuras magnificadas e que dominam os poderes xamânicos. O episódio em que participa Moco se passa, em certa medida, nos tempos mitológicos, em que o encontro pode resultar na guerra, em que os protagonistas se preparam para o ataque antes de estabelecer alguma forma de diálogo ${ }^{101}$. O barulho do barco de Chico Severo, um

\footnotetext{
${ }^{99}$ Dois Deni que deixaram a região do Cuniuá ainda jovens e passaram mais de uma década morando em Itacoatiara-AM disseram não ter esquecido a língua porque só conversavam entre si em deni.

${ }^{100}$ Alguns verbos foram incorporados do português, como precisar, comprar, vender, e também pesos e medidas foram acrescentados à língua deni, como lata, balde, litro, quilo, alqueire.

${ }^{101}$ Nas histórias Deni, é comum alguma pessoa encontrar alguma entidade e se preparar para matá-la. A vítima, por sua vez, ora dá instruções de como deveria ser morta, ora oferece alguma coisa para não ser morta.
} 
patrão, é o prenúncio do perigo de morte que só é desfeito efetivamente pelo estabelecimento do comércio, mesmo após o diálogo sobre a pacificidade dos indígenas, não há menção ao fim da tensão, que só desaparece da enunciação após o início do comércio.

Isto se torna especialmente marcado na versão do surgimento dos brancos no Xeruã fornecida por Azevedo. Nela, o encontro se dá durante uma grande caçada, quando encontram um comerciante que "chamou os Deni para trabalhar. Ele disse: 'Olha, couro de bicho é o produto de vocês. Podem trazer que eu compro'. Ele mostrou para o grupo Deni como preparar o couro. Aí, ele deu terçados para eles, roupa, sal, açúcar, facas, espingardas.” (2007: 54). Após ter sido estabelecido esse encontro pacífico, durante o qual os Deni se engajam no comercio e na atividade extrativista, a narrativa continua e menciona uma aldeia dos Jarawara que "não queriam os brancos em sua terra". Ela ficava no meio do caminho para outra aldeia que queria comerciar com os brancos e isto levou a organização dos brancos que "atacaram os Jarawara matando quase todo mundo" (2007: 54). No que diz respeito aos patrões, guerra e comércio aparecem entrelaçados, se há comércio, a violência parece ser controlada, já seu impedimento é posto como causa do seu surgimento.

Há, aqui, certa semelhança com o que disse Lévi-Strauss (1976 [1942]) sobre guerra e comércio a propósito dos Nambikwara e outras populações indígenas. Até mesmo o diálogo inicial apresentado pelo autor, no qual ocorrem saudações e afirmações sobre as disposições pacíficas, está presente. Embora os Deni apontem em seus discursos que a maioria das guerras antigas ocorria entre aqueles que falavam sua língua, a única narrativa sobre conflitos cujos participantes eram pais e avôs das pessoas vivas atualmente, isto é, os protagonistas eram parentes que estabelecem uma relação de continuidade com o tempo presente, foi dirigida contra não falantes do deni. É possível que a maioria dos ataques do passado tenha envolvido os Apurinã ${ }^{102}$, tidos como especialmente guerreiros e cujo idioma é, segundo os linguistas (o incluem na família linguística aruaque) e os próprios Deni, muito diferente; mas como dissemos a história das guerras esta sendo expurgada da memória.

\footnotetext{
102 Os exploradores que passaram pela região no século XIX apontaram que os Apurinã eram uma população guerreira (Ehrenreich 1948, Steer 1949) e que, frequentemente, faziam guerra com os Jamamadi, isto é, atacam as populações da terra firme. Entre os alvos dos ataques poderiam estar incluídos os ancestrais dos Deni atuais.
} 


\section{Os patrões do Cuniuá: da visita de Chico Severo ao surgimento da TI Deni}

A partir do primeiro encontro com Chico Severo, começa, no Cuniuá, o mesmo processo que mencionamos brevemente para o Xeruã. Ocorre uma intensificação da vivência com os não indígenas, durante a qual os Deni se engajaram ativamente no extrativismo, deixando de lado, muitas vezes, a vida da aldeia para habitar junto aos brancos. Embora estejamos dizendo os brancos, havia, também, alguns indígenas não Deni envolvidos neste processo, mas sua identidade indígena parece ser questionada pelos próprios Deni. Possuímos um grande número de narrativas sobre este período, muitas das quais envolvem apenas um Deni trabalhando/vivendo em meio aos brancos, raramente sendo fornecida uma versão de algum episódio no qual outra pessoa ainda viva teria participado.

As histórias de vida dos homens adultos com mais de 30 anos das aldeias Cidadezinha, Marrecão e Sikuriha ${ }^{103}$ mostram que, durante grandes períodos de suas vidas, a convivência intensa com os brancos era algo desejável. Patrões, regatões, ribeirinhos, missionários, americanos, rezadores, dentistas, aplicadores de injeção, peruanos, padres e outros tipos de kariva foram surgindo no mundo (e sendo difundidos pelas narrativas), bem como as vilas e cidades que vão desde o Peru até Santarém, Porto Velho ou mesmo São Paulo. Progressivamente, os Deni foram estabelecendo relações e trabalhando em sua manutenção, em alguns casos até hoje, num processo crescente que começa a decair com a crise da sorva nos anos 1980 e quase termina com a demarcação da TI Deni no início do século XXI.

A demarcação das terras indígenas na região e a crise do extrativismo levaram ao declínio dos antigos vínculos, mas estes processos resultaram no surgimento de novos tipos de brancos: enfermeiros, médicos, os trabalhadores das ONGs. Nos anos recentes, por volta de 2008-2010, as relações com os brancos dos mesmos tipos de antes foram retomadas e intensificadas com as crescentes viagens às cidades da região. Agora, além de antigos e novos patrões, surgem também os funcionários da recém-criada Coordenação Regional do Médio Purus da FUNAI, os políticos de Tapauá...

Durante o período de ocupação não indígena do Cuniuá, havia uma ampla distribuição das colocações destes, algumas com uma só família, outras formando

\footnotetext{
${ }^{103}$ Não pudemos obter informações para a totalidade dos velhos que habitam em aldeias do Cuniuá, mas isto deve ser válido também para as aldeias Viagem/Zunamete e Volta Grande e, possivelmente, o mesmo poderia ser dito para a Samauma, embora nesta última, devido a sua migração tardia para a margem do Cuniuá, possa não ter envolvido a totalidade dos homens mais velhos.
} 
pequenas vilas com algumas famílias. Não é possível precisar quando sua presença tornou-se quase continua desde a boca até o alto Cuniuá, onde este se transforma praticamente em um igarapé, mas a ocupação foi progressiva e, em dado momento, passou a influenciar a localização das aldeias Deni que trocaram a terra firme pela proximidade de um dos grandes patrões (na perspectiva Deni): Chico Severo, Adriano e Bernardo. Estes, que possivelmente eram ribeirinhos que conseguiam servir, num primeiro momento, de intermediários, quase exclusivos, entre as mercadorias vindas do Purus e os produtos extraídos do Cuniuá, perderam, depois, influência para os regatões, barcos que servem como espécie de barracão, mas não estão fixados em um local.

Cardoso aponta que, na segunda metade do século XIX, o aviamento incluía também o transporte de pessoas para a região do Purus, que, persuadidas pelas "mais variadas artimanhas de convencimento" (2011: 23) a migrar, eram levadas até os seringais da região do Purus e afluentes. É possível que algo semelhante ocorresse no início e meados do século $\mathrm{XX}$, mas, invés dos seringais, os recém-chegados eram entregues a algum intermediário local que alocava a mão de obra pelos rios. Os Deni eram submetidos a procedimento semelhante, sendo muitas as histórias de vida que mencionam períodos em que a pessoa era deixada em um igarapé, por períodos que variam de alguns dias até muitos meses, para trabalhar em alguma atividade: extração de leite de sorva, derrubada de madeira, obtenção de óleo de copaíba, etc..

Muitos Deni jovens e crianças, principalmente homens órfãos de pais e pessoas que eram criadas por outros parentes, abriram mão da vida na aldeia para habitarem em meio aos brancos. Alguns se estabeleceram junto a Chico Severo e Adriano, outros mantiveram relações com uma família durante um tempo, depois mudaram sua residência para próximo de outra, por períodos que variavam de semanas até alguns anos. Algumas famílias continuaram a viver nas aldeias, sendo os homens realocados para trabalhar durante alguns meses em um igarapé, depois em outro, no próximo ano em outro... Conforme houve um aumento no fluxo de barcos para o Cuniuá, houve, também, a expansão das áreas exploradas, alguns indígenas sendo levados para o Purus, para outros rios, alguns assumindo posições nas tripulações dos barcos, alguns migrando para Manaus e outras cidades do interior do Amazonas.

Nesse processo, cada Deni estabeleceu relações com determinados patrões, sempre em número limitado, de forma a obterem algumas mercadorias. Não ocorreu um processo de multiplicação desses vínculos, tal como seria o caso dos Paumari, notado 
por Kroemer, que "[d]evem tudo a todo mundo, porém a cada um somente um pouco" (1985: 136). Cada Deni deve o máximo que pode a um ou outro comerciante, podendo, inclusive, realizar compras para algum parente dentro de sua conta, tornando-se, por sua vez, patrão em relação ao seu devedor. Esse processo, que aumenta as possibilidades de compra, sem aumentar o numero de relações diretas com um patrão não indígena, é muito comum nos anos recentes, servindo como principais intermediários os professores, agentes de saúde e aposentados ${ }^{104}$. A relação com um patrão é a forma de obter mercadorias, mas não parece estar restrita a isso na ótica Deni.

Os patrões são associados ao universo do xamanismo, o que se torna evidente na sua capacidade de mobilizar potências de outras partes do cosmos (as mercadorias). Essa identificação coloca os patrões em uma posição em que as capacidades destrutivas estão presentes, não sendo incomum reputarem diversos assassinatos a alguns dentre eles. Os episódios de violência entre índios e brancos eram corriqueiros, brigas e desentendimentos ocorriam frequentemente, mas, aqueles que levaram a morte de indígenas $^{105}$, pois os Deni afirmam insistentemente que mesmo sendo mortos nunca mataram um branco, aconteciam, geralmente, em narrativas que envolvem barcos, ou seja, estão relacionados com algum patrão. Mesmo as mortes ocorridas entre os não indígenas sinalizam essa associação.

As narrativas sobre os eventos que levaram a morte de um dos grandes chefes, irmão de um dos chefes atuais da aldeia Cidadezinha, torna isso evidente. Obtivemos a primeira informação acerca deste evento em meio a uma listagem das brigas que envolveram indígenas e branco, após afirmarem que as brigas eram de socos e ninguém morria mencionaram: "Zeca Galinha, ele era Regatão e viajava aqui, agora mora no Tapauá. Ele matou o Isaruha. Zeca Galinha era casado com Dona Tiana. Ninguém vingou essa morte". Versões mais elaboradas, mesmo as que descrevem as circunstancias do assassinato, deixam a autoria do crime diluída no "pessoal (kepei) do Zeca Galinha”, como é possível apreender da narrativa um pouco mais detalhada de que dispomos, fornecida pelo irmão de Isaruha.

\footnotetext{
${ }^{104}$ Para uma visão mais detalhada da dinâmica das dividas e subdivisão das contas ver Florido (2013).

${ }^{105}$ Em realidade, só temos informação sobre a morte de um Deni por um não Deni que não era patrão, porém, não sabemos também se ele seria de outro grupo indígena. Foi um caso envolvendo o adultério entre a mulher do assassino e um jovem Deni que, convidado pelo marido traído para uma caçada, foi morto na floresta.
} 
Primeiro morávamos todos juntos. Isaruha estava na Cidadezinha e quis subir para o Marrecão com o Zeca Galinha. O pessoal do Zeca estava bebendo e deram bebida para o Isaruha. Ele ficou bêbado e entrou no barco. Começaram a brigar. Ele só tinha um braço. Quando estavam na Ressaca ${ }^{106}$ empurraram as costas deles com a sola do pé para jogar ele fora do barco. Ele bateu a cabeça na borda do barco e afundou. Não apareceu mais na água, faleceu.

A associação com os patrões nunca é vista como algo inteiramente positivo, ao menos segundo as lembranças que delas circulam nos anos recentes. É quase invariável a visão de que trabalhar para um patrão trazia mais desvantagens do que mercadorias. São comuns os relatos a respeito do excesso de trabalho pelo qual recebiam apenas cachaça, sendo negado o acesso às coisas boas. Alguns afirmam que eram levados para regiões distantes e deixados sem um meio de transporte e com alimentação insuficiente; outros que eram impedidos de fazer roçados; ou que eram obrigados a ficar devendo sem poderem pagar suas contas; ou mesmo que tiveram saldo junto a comerciantes que desapareceram após navegarem um ou dois anos pela região.

Um homem, com aproximadamente 35 anos, afirmou que, durante dois anos, trabalhou para um patrão da seguinte maneira: quando chegava o barco, ele comprava algumas mercadorias, que deixava com sua esposa, e era levado para uma colocação para trabalhar e pagar a conta. No terceiro ano, recebeu uma espingarda que havia encomendado no segundo ano de trabalho. Ele disse para o patrão que gostaria de trabalhar para pagar a arma sem fazer uma nova conta, ao que obteve como resposta que, se não comprasse outras mercadorias, perderia a espingarda, tendo ai se iniciado sua dívida perpétua. É curioso, pois, quando não havia dívida, a pessoa que trabalhava não era a que consumia, as mercadorias ficavam com as esposas e filhos, sendo o consumo do trabalhador postergado para o momento de endividamento.

Os kariva viviam muitas vezes nas mesmas condições dos indígenas, tendo a incorporação das roupas, da forma de construção das casas, da espingarda, do forró, levado a um reforço dessa identificação. Os ribeirinhos que viviam do extrativismo, da caça, da pesca e do roçado eram, igualmente, obrigados a se submeter a um patrão para obter as mercadorias e eram, também, alvo da violência associada a estes. Trabalhar

\footnotetext{
${ }^{106}$ Nome de uma localidade no rio, acima da Cidadezinha e abaixo do Marrecão.
} 
para um patrão faria parte do processo de pacificação do mesmo, uma forma de controlar a sua violência e evitar a guerra; seria algo semelhante aos presentes dados aos xamãs para que eles fiquem animados, isto é, não tenham raiva e não deixem as pessoas doentes. Acima mencionamos como os Jarawara, segundo os Deni do Xeruã, ao terem recusado o patrão, sofreram um ataque e foram obrigados a fugir. Um evento semelhante teria ocorrido no Cuniuá, havendo um local, na beira do rio, conhecido por ter sido palco de um massacre realizado pelo avô de um dos comerciantes que circulava pelo Cuniuá. Segundo o relato, os brancos teriam jogado uma bomba ${ }^{107}$ e matado todos os indígenas do local, no qual ficou apenas uma grande quantidade de sangue.

Os primeiros momentos com um patrão novo parecem ser aqueles em que há um enorme empenho produtivo. O esforço inicial para domesticar seria maior do que aquele aplicado para manter a relação e isso se torna evidente tanto a partir dos discursos indígenas quanto no de Adriano Lopes. Um Deni, com aproximadamente 40-45 anos, descreveu como, nas duas primeiras vezes que trabalhou para o branco, participou de espécies de competições, envolvendo indígenas e não indígenas, nas quais, quem tivesse a maior produção, ganharia um gravador. Nas duas primeiras vezes, ele produziu um volume de produtos muito superior aos outros competidores, ficando com o gravador, mas, a partir da terceira vez, passou a não produzir o suficiente para saldar a sua divida. Processos semelhantes estão presentes na história de vida de muitos, nos quais, primeiro, trabalhavam em troca de nada ou quase nada, e, depois, estabeleciam dívidas, passando a consumir mais mercadorias.

Se, para os indígenas, o inicio da relação com os patrões é percebido como um momento em que se trabalha muito, o mesmo aparece formulado em uma entrevista fornecida por Adriano, um dos patrões que exploraram a mão de obra indígena desde quando ficaram sabendo de sua presença na região. O depoimento gravado em 1979 e disponibilizado por Kroemer é o seguinte:

Estes índios apareceram há uns 25 anos atrás (entrevista gravada em 1979). Há tempo observávamos sinais de presença de índios bravos. Minha mulher estava com muito medo. Um dia, ela e meu filho, que naquela época tinha 10 anos de idade, viram um índio. Tomados de medo, voltaram depressa

\footnotetext{
${ }^{107} \mathrm{O}$ uso de explosivos para pesca foi uma prática utilizada na região.
} 
para o nosso tapiri para me chamar. Então comecei a atração desses índios nus e arredios. Dei comida e convidei eles a permanecerem por ali. E, aos poucos, a confiança foi crescendo. Dei roupa, e os índios se fixaram na região do Marrecão por minha indicação. Por serem bons conhecedores da floresta, usei os índios para exploração de sorva e copaíba, e para arranjar caça e peixe. Iniciei o trabalho com eles lá pelo ano de 1960. Nossa amizade continua até hoje, só que os índios já se tornaram safados e preguiçosos, principalmente desde a presença do Summer, a partir de 1975... (Kroemer 1997: 38)

A partir do comentário sobre os indígenas terem se tornado menos propenso ao trabalho, podemos imaginar que a situação inicial era diferente. No começo, os indígenas eram trabalhadores esforçados. Isto, contudo, não permanece assim por muito tempo, já que os indígenas transformaram-se, aos olhos de Adriano, em preguiçosos. O "Summer” (Summer Institute of Linguistics atualmente conhecido pela sigla SIL) não aparece como causa desse processo (a mudança não ocorre depois do Summer), mas como seu catalizador, a partir do qual ele teria se acelerado. Vale notar que Adriano situa o inicio da exploração da mão de obra indígena nos arredores de 1960 e a chegada do Summer em 1975, mas as datas podem ter sido incluídas por Kroemer.

O trabalho do linguista Paul Moran, ligado ao SIL, foi iniciado em 1965 (Koop \& Lingenfelter 1983), em uma aldeia Deni localizada no alto Cuniuá, no igarapé Maravilha, tendo ocorrido ao menos outra visita em 1967-1968. As permanências de Moran devem ter sido prolongadas, pois, os Deni afirmam que foram construídas casas para ele nas aldeias. Koop \& Lingenfelter apontam que a instalação da aldeia próxima a Adriano ocorreu em $1973^{108}$, tendo Koop, do SIL, chegado à ela em 1975 (mas como mostramos na introdução está foi a segunda migração). Temos, assim, que o grande volume de trabalho ocorreu provavelmente por volta de 1973, momento a partir do qual, garantida a pacificidade de Adriano pelas pessoas que compunham o primeiro movimento de migração, os novos Deni estabeleceram uma associação com o patrão e ela demandava a criação de uma disposição pacífica com eles próprios (os recémmigrados). Os depoimentos indígenas sobre essa segunda migração apontam que ela

\footnotetext{
108 Outra divisão da aldeia original do Maravilha, cujas pessoas e descendentes estão na aldeia Cidadezinha, foi se estabelecer próximo a Chico Severo alguns anos antes, não temos, porém, um depoimento de Chico Severo a respeito.
} 
ocorreu de forma rápida e integral, passando os Deni a dependerem da farinha de Adriano durante a abertura de um roçado coletivo de índios e brancos, a partir do qual foram obtidas as sementes para o plantio de um roçado Deni no ano seguinte.

As diversas narrativas sobre os trabalhos para algum patrão, até as que listam como único pagamento a cachaça, pontuam, sempre, que a farinha para alimentação durante o trabalho, mesmo que em quantidade insuficiente, era fornecida pelo patrão. $\mathrm{O}$ que temos, então, nos eventos que cercam a fundação da aldeia Marrecão, é uma aldeia inteira que passa, num primeiro momento, a trabalhar para um patrão, no esforço de consolidar uma associação pacífica, cuja manutenção posterior demanda menos trabalho. A presença de Koop e outros do SIL pode ter acentuado a percepção de que os indígenas trabalhavam menos para Adriano, muito possivelmente porque eles se voltaram para o novo patrão ${ }^{109}$ que precisaria ser pacificado.

Koop \& Lingenfelter (1983) apontam que Paul Moran encontrou, primeiro, os Deni morando no igarapé Maraviza, provavelmente, uma corruptela do nome Maravilha como é chamado em português, em 1965. Os Deni apontam que, no primeiro encontro com "Paulo Mourão", como o chamam, foi construída uma casa para ele no Kakiri. Ele era americano (amerikanu), o que significa que era um branco não falante do português ou espanhol, e ficou algum tempo na aldeia, descendo posteriormente o rio com seu barco. Após a saída de Paulo, a aldeia mudou de local, o que obrigou ele a viajando pela região até encontrar os Deni morando em outro igarapé, que o livro de Koop \& Lingenfelter afirma ser um igarapé afluente do Pretinho ${ }^{110}$, onde novamente construíram uma casa para ele.

Mesmo que não o tenha sido desde o inicio, nos dias atuais, Paul é visto como o primeiro missionário, uma categoria de kariva-patrões, mas que apresentam algumas características diferenciadas, como se interessar por outros produtos, como a língua deni, artesanato, histórias e, o que parece ser o principal diferencial, eles habitam nas aldeias $^{111}$ e são capazes de trazer mercadorias bem diferentes do que aquelas fornecidas

\footnotetext{
${ }^{109}$ O que define um patrão aos olhos Deni não é algo muito claro. As crianças e jovens me chamavam de patrão dizendo que eu era patrão por possuir muitas mercadorias. Os mais velhos algumas vezes me chamavam de patrão e se colocavam como fornecedores de produtos como histórias, sua língua, etc.. A venda da própria língua é algo que os Deni associam com os missionários e americanos, que, desde a presença inicial do SIL, pagam pelo aprendizado do idioma, levando indígenas para outras cidades como Porto Velho, para o estudo linguístico.

${ }^{110}$ Parece não haver uma clareza entre os Deni sobre qual seria o igarapé que os brancos chamam de Pretinho e Pretão.

${ }^{111}$ Muitos Deni, de outras aldeias que não a Cidadezinha, nos associavam com os missionários.
} 
pelos patrões não missionários: nos dias de hoje, placas solares, aparelhos de radiofonia... Todos os primeiros linguistas do SIL e missionários tinham suas casas construídas pelos indígenas que pareciam fazer de tudo para manter a presença destes novos patrões entre eles. As famílias Deni que se associaram a estes brancos, inicialmente no Kakiri, seguiram depois para o Diara, passando, depois, para a aldeia Marrecão Velho, onde foi construída a primeira pista de pouso, e, atualmente, seus descendentes estão divididos entre as aldeias Marrecão e Cidadezinha. Até recentemente, a atuação dos missionários, da Novas Tribos do Brasil e JOCUM, ocorria na aldeia Marrecão [Novo], onde foi construída uma nova pista de pouso, mas, nos últimos anos, transferiram suas atividades para a aldeia Samauma, a última a se fixar na margem do Cuniuá, na virada do século XXI.

O histórico dos missionários permite perceber que eles se portavam, e em certa medida ainda o fazem, como os patrões. Há aqueles que abriram espécies de barracão nas comunidades, fornecendo mercadorias como sal, açúcar, café, anzol em troca de sorva, farinha, copaíba, servindo de mediadores entre os comerciantes e os indígenas; e outros que introduziram a noção de artesanato, atuando como compradores de facas de madeira, canoas em miniatura, remos, cestos para pão, lixo, etc.. Esses patrões, contudo, se portavam de maneira ideal, já que, além de funcionarem como mediadores no fluxo de bens, sua atuação se estendia aos campos do cuidado a saúde e ao ensino; eles não só aplicavam injeções, mas ensinaram alguns a realizar a sua aplicação, para que pudessem fazê-la durante sua ausência e deixavam remédios. Também, a alfabetização de alguns Deni, na língua materna, foi realizada pela ação dos missionários.

Morar nas aldeias representa toda uma diferença, já que torna possível humanizar os kariva, tornando-os, no limite, madiha. Madiha é a forma de autodenominação que carrega o sentido de humano, sendo que outras populações indígenas são madi, mas não saberíamos precisar a diferença entre os termos. Perguntando se determinada população indígena era madi e não madiha a resposta invariavelmente dizia que se era madi era também madiha. Em deni _ha corresponde ao verbo ser/estar/ter. O dicionário de Koop \& Koop (1985), além da definição verbal, fornece uma tradução para a partícula enquanto um sufixo de terminação verbal $\_h a$, "aspecto distributivo, masc.”. Um Deni disse que madi seria usado pra indicar todas as pessoas, já madiha uma só, sendo utilizado pelos xamãs para marcar que os animais são também gente. 
Um dos missionários atualmente em atividade, que há décadas atua nas aldeias, é considerado madiha, o que é atribuído ao seu domínio do idioma; afirmação que já foi registrada por Azevedo (2007) uma década atrás. Quase todos os missionários dominaram a língua Deni, mas sua humanização não parece se limitar a isto, pois, além da língua, sua residência é muito similar a dos próprios Deni (em contraste com a do outro missionário). Embora não possamos abordar apropriadamente este processo, é interessante notar que, próximo ao final de nossa primeira etapa de pesquisa de campo, alguns se mostraram preocupados com a inexistência de farinha de mandioca em São Paulo, querendo que eu levasse algumas manivas para plantar.

Todos os brancos são tratados pelo termo vocativo para cunhados ${ }^{112}$ (abuni entre homens, ukharadi entre mulheres e uvini entre um homem e uma mulher), mas, aqueles que moram nas aldeias, acabam por ser inseridos na rede de parentesco. Ao abandonar o status de cunhado, passam a existir outras formas de relação, alguns se tornam irmãos, outros pais, filhos, genros, etc. Essa mudança de tratamento se faz acompanhar da adequação dos comportamentos correspondentes, havendo, inclusive, repreensão quando se adota o comportamento inapropriado frente à determinada pessoa: "Você não pode negar um pouco de açúcar para o seu pai...”.

A coabitação de um branco, que, como já mostramos acima, é alocado em uma casa própria (ou num barco, como é a forma de convivência adotada pelo CIMI), acaba por integrá-lo ao universo do parentesco, deixando de ser um puro afim. Não é sem razão que não há menções a brigas que envolvam brancos co-residentes. Mesmo os discursos que atribuem aos missionários alguns comportamentos que, quando envolviam outros brancos, faziam surgir a violência, como ter relações sexuais com mulheres Deni casadas, não incluem animosidades e violência. A própria mudança de local de atuação dos missionários, da aldeia Marrecão para a Samauma, é atribuída a um furto realizado enquanto eles estavam na cidade, o que faz paralelo ao que uma família, que mudou de aldeia em 2011, usou de justificativa para sua própria mudança: o furto de suas coisas enquanto estavam na cidade. As ações e reações ao comportamento dos não indígenas co-residentes são aquelas apropriadas ao convívio entre os parentes.

Para os homens mais velhos, ter um kariva na aldeia é algo desejável e que se busca ativamente nos dias de hoje. A cada viagem para a cidade, entre as descrições das coisas que aconteceram, está sempre presente a menção a algum novo patrão, ou

\footnotetext{
${ }^{112}$ Algo que não é incomum na Amazônia (ver Viveiros de Castro 2002).
} 
político, ou funcionário público, ou mesmo alguém já conhecido, que foi convidado para ir até a aldeia e o fará em breve, embora dificilmente o faça. Esse desejo pelo branco tornou-se evidente desde o início de nossa relação com os Deni. Após termos sido apresentados aos Deni pela Adriana Azevedo, que atuou entre eles enquanto trabalhava para o CIMI, e que sinalizou para os indígenas nosso desejo de ir morar em uma das aldeias, todo o resto tornou-se sem importância, não importando os motivos do antropólogo para a visita.

Conhecemos, inicialmente, algumas pessoas das aldeias Cidadezinha e Marrecão que estavam em Lábrea para uma reunião do movimento indígena, na qual foi fundada a FOCIMP (Federação das Organizações e Comunidades Indígenas do Médio Purus). Um dos indígenas, liderança da aldeia Cidadezinha, antes mesmo de nossa apresentação apropriada, insistia para que fossemos para a aldeia dele, usando como argumento o fato de que nunca um branco havia morado entre eles e que me dariam farinha, pirarucu, surubim, peixe-boi para comer e uma casa para morar, caso eu fosse para a comunidade dele. Independente de quem eu era, ou do que eu fosse fazer, eu era um branco de muito longe e, quanto tal, seria bom que ficasse entre eles. Após ter acertado que iria para a Cidadezinha, as motivações para minha estadia não eram de nenhuma importância, apenas quanto tempo eu ficaria e quando voltaria depois de ir embora é que se tornavam tópicos de conversação. Mesmo na aldeia, embora tenha ido a todas as residências e falado com todos os homens adultos que sabiam o português sobre as motivações da minha visita, nenhum dava importância, sendo o tempo da minha permanência o que, eventualmente, tornava-se um tópico de interesse.

No caderno de uns dos professores pudemos ver um documento ${ }^{113}$ escrito, segundo ele, elaborado em parceria com seu irmão, em português, com a seguinte mensagem:

\footnotetext{
${ }^{113}$ Parece haver entre os Deni a ideia de que o envio de documentos para ONGs, políticos e órgãos públicos é uma forma de obter mercadorias dos mesmos. Segundo os Deni da Cidadezinha, está é uma prática comum no Xeruã, dai eles receberem muitas coisas da prefeitura, missionários e FUNAI. Não é suficiente, contudo, enviar apenas um documento, devem ser enviados vários para que comecem a fazer efeito. Segundo afirmam, os documentos são lidos e jogados fora, sendo necessário o envio repetido para que sua eficácia apareça. É interessante notar que os brancos teriam uma atitude inversa a Deni no que diz respeito aos papéis escritos; enquanto nós leríamos e jogaríamos fora todos os papéis, os Deni parecem guardar tudo, desde receitas médicas da década de 1980, até algo obtido na cidade durante a última visita, os escritos são perdidos, apenas, pela ação das crianças, que eventualmente se apoderam deles, ou de outras fatalidades, como a chuva ou um naufrágio de canoa. Interessante notar que muitos Deni que passaram muitos anos morando entre os brancos, quando voltavam para a aldeia, traziam cadernos e canetas e fingiam saber escrever.
} 
"No dia 13/11/08 foi realizada uma segunda reunião das 6 aldeias. A população Deni do rio Cuniuá pede um branco para o Governo Federal. Nós queremos continuar nossos direitos.

Rangel de Morais/FUNAI

Greenpeace

FUNASA

CIMI

Missionário"

A presença de um kariva é o ponto, mas a lista ao final mostra que ele se destinaria aos que possuem origem distante. Ele não se dirige simplesmente a FUNAI e sim ao funcionário de Manaus e não o de Lábrea, evoca as organizações com quem se relacionaram nos anos recentes e que são compostas por pessoas de origens as mais distantes possíveis.

Embora esta seja uma visão construída com base nos últimos anos, parece que, ao longo de toda a história de convívio com os brancos, as mercadorias diferentes são aquelas que têm sua origem mais distante. Primeiro eram mercadorias vindas de Manaus, mas que deviam ser consumidas amplamente pelos kariva da região; depois os missionários (inicialmente o SIL) com sua origem distante e bens não possuídos na região, num processo que se mantem até os anos recentes, com a chegada do Greenpeace e seu navio equipado com internet, televisão, ou dos missionários atualmente em atividade com seus notebook, barco equipado com sonar, até o antropólogo com minigravadores... A origem distante desses kariva dá acesso a mercadorias diferentes, sinalizando sua capacidade de acessar regiões muito poderosas do cosmos; a convivência com eles torna possível obter e se beneficiar dessas forças.

É interessante notar que, os próprios Deni parecem ter introjetado seu afastamento em relação aos brancos, mais especificamente as cidades, nos seus discursos de carência, acrescentando ao "nós não temos nada" a referência espacial "nós moramos longe”. A falta de brancos na região, atribuída com certo ressentimento à FUNAI, acaba se traduzindo numa percepção de que estão longe da fonte de poderes e 
mercadorias, isto é, das cidades. Embora não haja, ainda, uma migração maciça dos Deni para os centros urbanos, os que habitam nas cidades e suas proximidades deixaram a vida nas aldeias décadas atrás, se iniciou, em 2011, um movimento migratório da comunidade Samauma, a mais distante em relação ao rio Purus, para abandonar a TI Deni e se instalar em uma colocação no Cuniuá abaixo do rio Riozinho. Essa mudança foi motivada por um kariva que convidou alguns Deni para abrirem um roçado junto ao que ele mantém no local.

Howard (2002) afirma que há um paradoxo na topologia social Waiwai. Por um lado, eles se concebem como estando no centro do cosmos e as cidades ('aldeias enormes'), as quais visitam raramente e cujos habitantes são marcados pela carência de socialização, são postas na periferia do cosmos. Por outro lado, as 'aldeias enormes', distantes, são tidas como fornecedoras de remédios, mercadorias, doenças e etc., o que situaria a aldeia numa posição marginal, que dependeria desses centros onde são geradas as potências. Segundo a autora, essas imagens contrastantes "expressam as diversas facetas de uma profunda contradição inerente ao contato e a tensão que ela gera entre modos opostos de conceber as dicotomias 'índios/brancos' e 'centro/periferia'." (Howard 2002: 42). Haveria uma divisão no pensamento Waiwai entre os membros da sociedade ocidental, cuja vida se orienta para a cidade, mesmo que não habitem em uma delas, e os indígenas e quilombolas que seriam 'habitantes da floresta' marcados pela autonomia social e econômica.

No contexto Deni as dicotomias índios/brancos, centro/periferia, floresta/cidade se desenvolvem de forma muito diferente. Não há uma elaboração narrativa sobre a origem das mercadorias, existindo, apenas, a noção de que alguns dentre os kariva possuem a capacidade de trazê-las de longe e de que todos podem obtê-las facilmente nas cidades. Durante décadas, os Deni viveram, literalmente, em meio aos brancos e ambos tinham que estabelecer relações com os patrões para obter as mercadorias de que necessitavam. As cidades são tidas como centros de difusão desses bens, assim, tanto índios quanto brancos, independente de morarem na floresta ou na cidade, têm de estabelecer relações que os conectam ao meio urbano de forma a obterem as mercadorias/potências que valorizam. A topologia social Deni parece, então, situar o centro nas cidades, que, como eles sabem desde Tamaku e Kira, foi o ponto de surgimento da humanidade. Miguel Aparicio aponta que no final do processo de criação da TI Deni, uma das lideranças dizia: "Daqui para frente, meu porto é Lábrea" (2011: 
120), sinalizando sua orientação para a cidade, local a partir do qual os poderes dominados pelos kariva se irradiam.

\section{Da demarcação às cidades}

A exploração do leite de sorva, um dos principais produtos da atividade extrativista na região do Purus, entrou em decadência nos anos 1980. Pastore Jr. \& Borges (s.d) apresentam dados do IBGE de 1995 a respeito da produção de sorva na região Norte entre 1970 e 1993. A partir de 1979 (quando se extraia mais de cinco toneladas e cujo valor ultrapassava US 7.000.000) há uma grande queda no volume de produção e no preço da sorva que quase desaparece em 1980, ficando abaixo de uma tonelada. A produção, a partir de então, não alcança valores significativos, mesmo que haja uma recuperação da extração em 1982-1983, ela volta a níveis baixíssimos em 1987.

Essa queda na produção da sorva e a demarcação das Terras Indígenas na região nos anos 1990-2000 levaram a migração dos habitantes não indígenas do Cuniuá. Chaves (2001), responsável pelo relatório de demarcação da TI Deni, aponta que só existia uma colocação de não indígenas na região do Cuniuá que hoje faz parte da área Deni, durante sua pesquisa de campo em 1999. Atualmente, há apenas algumas poucas colocações não indígenas acima do rio Piranhas e nenhuma acima do rio Riozinho, dois afluentes do Cuniuá, muitos quilômetros abaixo do limite da TI.

Após a demarcação, alguns regatões continuaram a viajar pelas aldeias, em ritmo decrescente, havendo, nos últimos anos (2010-2012), apenas um atuando na região, com uma ou duas viagens anuais, mas ele parece ter excluído a TI Deni de sua rota atualmente. Os únicos brancos a atingir a região pela via fluvial regularmente ${ }^{114}$ nos, anos 2000, são os dois missionários (um deles possui um barco), pessoas ligadas a secretaria de educação do município de Tapauá, durante a entrega ocasional de merenda para os professores, e os que trabalham na Fundação Vigilância em Saúde, responsável pelo combate de malária, que fazem uma ou duas visitas anuais às aldeias. Essa diminuição da circulação de não indígenas pelas aldeias Deni foi acompanhada por uma

\footnotetext{
${ }^{114}$ Algumas organizações, como CIMI e OPAN, realizaram trabalhos na região, durante os quais faziam algumas viagens anuais para as aldeias do Cuniuá. Em 2011 houve uma viagem dos funcionários da Embratel que instalaram orelhões nas aldeias Cidadezinha, Marrecão e Samauma. Em 2012 houve uma viagem da secretaria estadual de educação.
} 
diminuição no fluxo de mercadorias, mas não de forma muito intensa, e que não resultou em um período de carência prolongado.

Para os Deni, a história do contato se encaminha em outro sentido, ela é vista como a história do melhor acesso aos bens, já que, a cada novo kariva que surge ao longo da história, uns mais distantes que os outros, vão surgindo novas mercadorias anteriormente desconhecidas. O processo histórico Deni é um movimento em que, progressivamente, os Deni tomam para si estes poderes cósmicos que, sem uma marcação clara sobre a forma como se originam, estariam no mundo desde o seu princípio. O que acontece é uma apropriação progressiva do conhecimento necessário para acessar as potências do cosmos. As cidades são os pontos a partir dos qual esses bens são difundidos, tendo os Deni adquirido o saber necessário para poder acessá-las regularmente, se deslocando de forma cada vez mais frequente para elas.

Teixeira-Pinto (2002) aponta que para os Arara, contatados por uma "Frente de Atração" da FUNAI, o enigma do contato seria entender como, após um inicio de fluxo abundante de mercadorias, ocorreu a diminuição da sua disponibilidade, quando a Frente transformou-se em um "posto indígena regular", com recursos mais limitados. Essa mudança, entre um período de abundância e a posterior escassez, teria levado a uma reelaboração sobre o contato por parte dos Arara. Os Deni parecem não ter vivenciado algo semelhante, ao tomarem o contato em seus próprios termos, procurando os brancos para chegar as seus bens e não tendo sido alvo de uma frente de atração, os brancos e as mercadorias não precisaram ser reelaborados. O processo iniciado com as viagens até os brancos no Xeruã e, agora, para as cidades é o mesmo, representando uma progressiva melhora nos meios de se obter os bens.

As três maiores aldeais do Cuniuá (Cidadezinha, Marrecão e Samauma) conseguiram, ao longo das últimas décadas, obter melhores formas de deslocamento e de aquisição de mercadorias nas cidades; sendo as outras três (Zunamete, Volta Grande e Sikuriha) o resultado da cisão de uma comunidade maior que não alcançou alguma forma de comunicação mais eficiente com as fontes de mercadorias. Alguns moradores da aldeia Marrecão, onde se localiza a pista de pouso, passaram a ser transportados periodicamente de avião para Porto Velho, onde há uma missão criada especialmente para os Deni. Nela, eles trabalham roçando a fazenda da missão, ou contando histórias, em troca de pagamentos que são, próximo ao final da sua estadia, convertidos em 
mercadorias. Essas viagens permitem a aquisição de muitos bens e uma quantidade enorme é também enviada sob a forma de doações para os moradores da aldeia.

A demarcação da TI Deni foi alvo de uma campanha do Greenpeace, motivada pelos interesses da madeireira Malásia WTK que havia adquiridos terras no município do Tapauá-AM, com o objetivo de extrair madeira, e estas se sobrepunham ao território que os Deni exploravam. Além da publicidade a respeito, esta organização enviou um barco para o Cuniuá para ser usado pelos os Deni no escoamento da sua produção. Este barco foi deixado na aldeia Samauma, a última subindo o rio Cuniuá, mas, parece não ter sido usado para o fim ao qual se destinaria. Nos últimos anos, no contexto em que os Deni começaram a acessar seus direitos a aposentadoria e a receberem bolsa família, ele tem sido usado frequentemente, uma vez a cada dois ou três meses, pelos moradores desta aldeia para viagens às cidades de Lábrea, para onde se dirigem os aposentados, e de Tapauá, onde recebem o bolsa família.

Tendo o barco doado pelo Greenpeace sido levado para a aldeia Samauma, isto fez com que as outras comunidades demandassem um para si, pedido que foi atendido para a aldeia Cidadezinha que recebeu um barco da FUNAI, alguns anos atrás. Este, também, não foi utilizado para o transporte dos produtos da atividade extrativista, que continuavam a ser trocados com os regatões que ainda circulavam pelo rio. Quando as pessoas mais velhas começaram a se aposentar em 2009, este barco passou a ser usado no transporte, porém, frequentes naufrágios fizeram com que o barco fosse abandonado em 2010. Os aposentados adquiriram um novo barco, no final de 2010, para se locomoverem à cidade de Lábrea, onde recebem seu beneficio. Em 2011, um grande número de moradores passou a receber o bolsa família, dando início a viagens para a cidade de Tapauá, ficando o barco menos tempo na aldeia do que nas cidades ou viajando pelos rios.

Essas formas de locomoção tornaram possível, aos próprios indígenas, acessar diretamente os locais onde estão as mercadorias e os poderes mobilizados pelos brancos. Como apontou Azevedo (2007), a instalação do Distrito Sanitário Especial Indígena do Médio Purus no ano de 2000 e a contratação de Agentes Indígenas de Saúde (AIS) nas aldeias Deni fez com que, pela primeira vez, alguns Deni do Cuniuá passassem a ter uma renda regular ${ }^{115}$. Em 2002, foi iniciado o curso de formação de

\footnotetext{
115 Em realidade, já havia ao menos um Deni do Cuniuá que recebia um beneficio do governo, por invalidez. Ele, porém, passava (e ainda passa) muitos meses vivendo em Lábrea ou viajando no barco de
} 
professores indígenas, do projeto Pira-Yawara, na região do Tapauá, tendo, no ano seguinte, sido contratados os primeiros professores das aldeias do Cuniuá, cujo número tem crescido anualmente com a contratação de novos professores. Essas duas primeiras fontes de renda, e mesmo as aposentadorias, parecem ser percebidas como possibilidades de ganho que estavam disponíveis nas cidades, mas que os Deni só puderam acessar graças à mediação inicial de um dos missionários em atuação. A partir do momento inicial, contudo, os próprios Deni passaram a ter o conhecimento para explorarem essas fontes de recurso, já que, atualmente, se mobilizam para conseguir a contratação de novos $\mathrm{AIS}^{116}$, professores e obterem aposentadorias, bolsa família e salário-maternidade do INSS.

Na visão Deni, o contato com os brancos, durante os anos que estes viveram no Cuniuá, foi positivo, pois permitiu a obtenção do conhecimento sobre determinados poderes e mercadorias, mas sua migração, para longe da região da TI, não foi percebida como uma perda dessas potências. Se atentarmos para o surto de sarampo de 1992, durante o qual faleceram 62 pessoas entre moradores do Cuniuá e do Xeruã, o que corresponderia, segundo o CIMI, a 12\% da população (Chaves 2001: 65), mesmo que este evento tenha ocorrido após o processo de esvaziamento da presença não indígena, ele nunca foi, expressamente, atribuído a migração dos brancos. A única referência à origem do sarampo que implica os brancos, e não poderíamos afirmar mesmo que seja uma referência a última das epidemias de sarampo, afirma que foi um Padre que distribuiu roupas pela região que levou a doença ${ }^{117}$. A grande mortalidade foi repetidamente atribuída à falta de remédios ${ }^{118}$, isto é, um tipo de mercadoria semelhante e diferente daquela usada pelos xamãs.

É interessante notar que a categoria "remédios" (hemedi ou hemezi na língua Deni) é atualmente aplicada, também, para as plantas e outras substâncias usadas para tratar algumas condições, geralmente problemas de saúde das crianças, dores de dente, ou tornar os cachorros melhores na caça, mas, também, podem ser usados para picada de cobra. O conhecimento sobre eles é variável, alguns são de amplo conhecimento e

algum patrão. Os AIS foram os primeiros moradores exclusivamente das aldeias que tiveram acesso a um salário regular.

${ }^{116}$ Segundo alguns, a aldeia Volta Grande foi formada por uma parentela que objetivava obter um AIS e professor.

117 A maior parte das doenças teria sua origem nos xamãs, mas algumas são associadas com a cidade, como o catarro e a diarreia, parecendo ser o vento a forma através da qual são difundidas.

${ }^{118} \mathrm{E}$ uma das reclamações constantes dos Deni em relação aos serviços de saúde diz respeito à pequena quantidade de remédios que estariam disponíveis nos postos de saúde das aldeias. 
aplicados de forma irrestrita, já outros foram conhecidos através do contato com outras populações indígenas e não indígenas. No caso dos problemas infantis, muitas vezes, é o xamã quem indica o uso, após ter identificado qual animal/espirito teria causado o problema infantil, recomenda o uso de determinada planta ou substância como tratamento.

Como já afirmou Azevedo (2007), o vocabulário do xamanismo é mobilizado pelos doentes que fazem tratamento na cidade para a descrição da medicina, a qual se atribui tanto a cura quanto a morte do paciente, dependendo da ação dos médicos que dão remédio ou veneno para o tratamento. São os remédios que causam a morte ou a cura. Tal como o xamã novo (zuphinehe zati), cuja presença da pedra-poder (katuhe) em seu corpo permite curar doenças (e a partir de certa quantidade acumulada também causar), mas não lhe dá conhecimento sobre o cosmos, os brancos conseguem utilizar os remédios, mesmo sem possuírem um conhecimento especial sobre o mundo ${ }^{119}$, estando limitados a tratar algumas condições de saúde, mas não outras.

As viagens aos locais distantes tornaram possível a aquisição direta de alguns medicamentos, tornando os Deni conhecedores e consumidores de novas potências que os patrões vendem e indicam a utilidade. Os moradores de Marrecão, durante suas estadias na missão em Porto Velho, obtêm remédios dos amerikanu ${ }^{120}$, que seriam capazes, por exemplo, de tornar as pessoas imunes à gripe ${ }^{121}$, uma das principais causa mortis de crianças e adultos. Os moradores de Cidadezinha e de Samauma, por sua vez, ganharam acesso a outros tipos de medicamento nas cidades de Lábrea e Tapauá. Por um lado, conseguem adquirir dipirona e alguns antibióticos que são vendidos nos comércios que frequentam, entre os quais estão incluídas as farmácias, e que tratariam as mesmas condições tratadas pelos profissionais de saúde; por outro, tem adquirido outros remédios com poderes mais variados, entre os quais estão alguns que se destinam ao tratamento de picadas de cobra (específico pessoa), gripe (xarope de mel, copaíba e andiroba; entre outras variações), curar dores no corpo (uma pasta para massagem com cheiro forte e agradável), tornar as mulheres mais acessíveis para o sexo (uma espécie

\footnotetext{
${ }^{119}$ Alguns afirmam que o médico possui algumas maquinas (como o raio-x) que permitem que ele veja a doença e o xamã que a causou, algo que os próprios xamãs fazem normalmente.

${ }^{120} \mathrm{O}$ casal que fundou a missão não é falante nativo do português.

${ }^{121}$ Há, para os Deni, duas condições que traduzem por gripe: thunure e pishika. Ambas podem ser fatais para crianças, manifestando-se através de tosse, catarro e febre. A pishika é uma versão forte, deixando as pessoas incapacitadas e causando muitas mortes entre adultos e crianças.
} 
de lata pequena com uma pomada em seu interior) e uma série de garrafadas, pomadas, latas e vidros que vão sendo conhecidos e comprados a cada nova viagem para a cidade.

Para os Deni, o meio urbano não é um ambiente seguro. Há diversos elementos nocivos e perigosos, aos quais se espoem aqueles que empreendem visitas às cidades, mas, isto não impede que muitas viagens sejam feitas, principalmente, mas não exclusivamente, por aqueles que irão receber algum beneficio social, como as aposentadorias, bolsa família e salário-maternidade. A cada nova ida ao meio urbano, todos sabem que irão surgir casos de diarreia (budikuma) e gripe/catarro (thunure), que depois irão se espalhar pelas aldeias, atingindo adultos e crianças.

Além dessas condições, especialmente perigosas para as crianças pequenas e recém-nascidas, há, também, aquelas que preocupam especialmente os adultos. A cidade é a área de atuação da "galeradeni": grupos de pessoas que saem à noite matando aqueles que encontram pelo caminho. Poucos são os Deni, geralmente homens adultos, que andam pelas cidades após o anoitecer, quando, além do encontro com galeradeni, podem acabar sendo vitima de um dos kariva alcoolizados. A associação entre consumo de álcool ${ }^{122}$ e violência está presente em muitos relatos, mesmo nos assassinatos de xamãs, nos quais eles seriam embebedados antes de serem mortos. Além da visão já constituída pelos próprios indígenas sobre os perigos associados ao consumo etílico, durante suas visitas, são alvo de muitos discursos de alguns conhecidos da cidade que abordam a questão dos indígenas que foram, recentemente, mortos em algum dos bares de Lábrea ou Tapauá.

Segundo os Deni, a obtenção de salários e benefícios, embora seja algo positivo, os colocou em uma posição perigosa. Existe a ideia, muito difundida, de que, na cidade, muitos dos brancos, ao ficarem sabendo que os indígenas estavam recebendo dinheiro de Brasília, ficaram com muita raiva e planejam matar os Deni. A obtenção, por parte dos Deni, do conhecimento para se valer dessas potências, que anteriormente eram de domínio exclusivo dos brancos, despertou sentimentos de vingança entre esses últimos.

Um dia, brincamos com um dos professores dizendo que todos os brancos sabiam que ele era o homem mais rico até Manaus e que, quando ele nos chamava de patrão, sabíamos que ele estava mentindo. Sua família era, de fato, a que usufruía de maiores recursos financeiros em relação às outras, pois, seu salário de professor,

\footnotetext{
${ }^{122} \mathrm{O}$ álcool faz parte da categoria zamahira (“coisa ruim").
} 
superior ao dos aposentados, era acrescido de um auxilio doença permanente, obtido em 2011 para sua filha adolescente deficiente, do bolsa família e do artesanato que ele costumava vender aos missionários. Após nossa brincadeira, que não despertou animação alguma nele, pelos dias seguintes, ele passou a sinalizar o desejo de abandonar o cargo de professor, isto é, queria diminuir sua renda e voltar a sua condição de freguês despotencializado. Sua afirmação foi feita diariamente até ele viajar alguns dias para seu roçado distante, não continuando após seu retorno. Parece que ele procurava sinalizar aos brancos (representados pelo antropólogo) que ele não era mais rico, que não tinha assumido o lugar do patrão, tradicionalmente ocupado por algum kariva.

O modo de se relacionar nas cidades é semelhante ao que se desenvolvia durante a presença não indígena no Cuniuá. Quase todos os AIS, professores, aposentados ${ }^{123} \mathrm{e}$ beneficiários do bolsa família estabelecem relações com determinado comerciante a quem elegem como seu patrão. Os indígenas entregam seus cartões de banco ou do bolsa família e, assim, conseguem se endividar e adquirir, às vezes de forma exclusiva, as mercadorias que desejam. A lógica das mercadorias em atuação no Cuniuá é reavivada no meio urbano, já que, tanto antes quanto agora, estabelecer uma dívida é condição sine qua nom de aquisição de mercadorias. Alguns objetos não vendidos junto ao patrão escolhido podem ser adquiridos, apenas, nos casos em que estes, além das mercadorias, fornecem dinheiro para que os Deni realizem compras em outras casas comerciais.

No processo em curso, iniciado em 2009-2011, os comerciantes adotam diferentes posturas em relação à demanda dos indígenas: alguns permitem que sejam feitas grandes dívidas, comprometendo quase um ano da renda, outros que sejam pequenas, que só comprem novamente após quitar a dívida anterior, que comprem um mês antes de terem saldo. A opção inicial de um Deni por se associar a um ou outro comerciante parece passar por outras considerações que não estão relacionadas, exclusivamente, com a forma como este patrão se comporta. Alguns adotam para si o mesmo patrão que um dos seus parentes, enquanto outros procuram novos patrões, interessados nas mercadorias que eles disponibilizam, não no sentido de garantir a

\footnotetext{
${ }^{123}$ Segundo um documento entregue por um dos missionários à FUNAI, os aposentados da aldeia Samauma fazem sempre compras a vista. Não sabemos, contudo, se eles fogem a lógica de se relacionar com apenas um comerciante de forma quase exclusiva. A partir de nossa observação direta e de conversas com alguns comerciantes podemos afirmar que os beneficiários do bolsa família procedem desta mesma forma, mantendo dívidas junto a um patrão e comprando preferencialmente dele.
} 
possibilidade de comprarem de tudo que necessitam, mas, antes, de adquirir bens diferenciados não disponíveis amplamente: aparelhos de DVD, gravadores, caixas de som com microfone, relógios, bicicletas...

\section{4 - Dos Kariva e seus poderes}

Embora não seja possível recuperar um histórico das mudanças ocorridas na visão sobre os kariva ao longo do contato, podemos imaginar que ela nem sempre foi a mesma. Se, por um lado, o contato é pensando a partir dos dias de hoje como uma progressiva apropriação dos conhecimento/poderes disponíveis no cosmos, por outro, os kariva, possivelmente, sofreram diversas mudanças ao longo do caminho. A denominação, no limite máximo de aplicação, inclui todos os não indígenas e não animais e deve ter chegado à região anos antes que os próprios não indígenas ${ }^{124}$, não sendo possível recuperarmos quais as teorias sobre os brancos que estariam em atuação no momento do primeiro encontro.

Uma primeira divisão da categoria kariva parece ter sido estabelecida com base na língua ${ }^{125}$. Os amerikanudeni foram distinguidos dos karivadeni ${ }^{126}$, os primeiros são os estrangeiros ligados ao SIL e muitos dos missionários que atuaram na região, que não eram/são falantes nativos do português. Perguntados, os Deni incluem prontamente os amerikanu entre os kariva, mas marcam que sua língua (ima) é outra. Kariva é, assim, idealmente, o falante do português. Entre os ocupantes não indígenas do Cuniuá, e mesmo os comerciantes que por lá passavam, existiam algumas pessoas originárias de outros países da América do Sul, sendo todos, segundo a memória Deni, peruanos falantes do espanhol. Eles se diferenciariam dos kariva por possuírem fala ruim (ima hirade), menos compreensível que a dos outros; não saberíamos dizer, contudo, se essa adjetivação não seria utilizada também para falantes do português com algum tipo de problema de pronúncia.

\footnotetext{
${ }^{124}$ Segundo Azevedo, kariva: "palavra de origem tupi adotada da língua geral brasileira (caraíba/cariú) que se refere aos 'brancos'.” (2007: 7). Ela também está presente em outras línguas da família arawá presentes na região, como a paumari, na qual corresponde apenas a patrão, e também no apurinã da família linguística arawak (Facundes 2000). Os Deni afirmam que kariva seria o nome na língua deni, sendo kariu a autodenominação dos brancos.

${ }^{125}$ Para os Deni, a língua (o idioma) é um atributo ligado ao corpo. Já vimos isto quando falamos de Tahama, que esqueceu a língua deni depois de ter sua língua raspada. A dificuldade que alguns deles têm de aprender o português faz com que digam que têm cabeça de queixada. Um fez referência ao sexo como um meio de aprender instantaneamente o idioma e, como veremos no capítulo 3, as relações sexuais levam a troca de atributos odoríficos entre os amantes. $126 \_$deni indica o plural.
} 
A associação entre amerikanu e kariva pode não ser tão antiga, podendo ser contemporânea ao surgimento da categoria “indígenas ${ }^{127}$ " na teoria Deni da alteridade, no âmbito da participação no movimento indígena ${ }^{128}$ da região do Médio Purus. Muitos dos que passaram a ser "parente" (sempre em português mesmo quando conversam entre si na língua deni), como são tratados por e tratam os outros indígenas, deviam, na época do auge do extrativismo, fazer parte dos kariva, principalmente aqueles que dominam o português, ou são falantes exclusivos dele. Alguns antigos moradores do Cuniuá que eram kariva, são considerados como indígenas nos dias de hoje, isto é, são referidos como "parentes" quando os Deni falam sobre seus encontros com estas pessoas que, atualmente, residem em Lábrea ou Tapauá.

Se amerikanu pode ser subsumido a kariva, outras posições, que numa simplificação poderíamos tomar por tipos de kariva não poderiam. Patrão, professor, enfermeiro, médico, vereador, segurança, policial, entre outras, são classificações aplicáveis à alguns kariva, mas parecem ser, antes, percebidas como relacionadas à posse de determinados conhecimentos do que qualquer outra coisa. Não são apenas elementos surgidos após o contato que participam desta lógica, pois, o mesmo se diz do xamã, a quem se atribui um saber exclusivo. Este saber, contudo, não é exclusivo dos xamãs Deni, já que alguns kariva são rezadores, possuem a capacidade de curar condições não suscetíveis à atuação dos remédios, isto é, detêm conhecimentos especiais que permitem retirar certar doenças das pessoas.

A posição de patrão parece ter sido a primeira a ser internalizada pelos próprios Deni, cujos chefes são chamados patarahu, mesmo termo aplicado aos patrões. Esta noção substituiu uma posição que associam com a figura do sushava, que corresponderia mais ao ideal de chefe ameríndio, tal como descrito por Clastres (1990 [1974]). Não há nenhum sushava nos dias de hoje. As descrições a seu respeito apontam que era um chefe ligado a realização dos imaamushinaha (festas rituais). Ele era responsável pela abertura de grandes roçados, consumidos por todos e não apenas durante o ritual. Alguns velhos apontam que, atualmente, não há patarahu de verdade, afirmando que os patarahu de hoje só querem as coisas para si.

\footnotetext{
${ }^{127}$ Os Deni não gostam do termo "índio". Azevedo afirma que isto seria por conta do termo "se parece muito com a palavra izu, ("merda", na língua arawá)" (Azevedo 2007: 110). Nas lembranças das brigas com os brancos, muitas incluíam diálogos iniciais em que um não indígena chamava algum Deni de 'índio', de forma pejorativa, antes de inicia os confrontos.

${ }^{128}$ Para ver o surgimento entre os Deni da noção de indígenas enquanto um conjunto oposto aos brancos ver Azevedo (2007).
} 
As narrativas das relações com os brancos sempre apontam que, no início, era um patarahu que fazia as compras junto aos patrões e depois realizava a distribuição aos moradores da aldeia. Não podemos afirmar se eram os sushava que assumiam esta função e, por consequência, se transformaram em patarahu, ou se, o ato de assumir o comércio interétnico levou a metamorfose de pessoas comuns em patrões. Um dos chefes atualmente em atividade relatava que, ele mesmo, chegou a ter uma loja em sua aldeia antes de vir a ser patarahu, ou seja, ele se portava como um patrão e não como um sushava.

Esta figura, embora não seja propriamente um acumulador, tende a ser aquele que detêm alguns bens que os outros não possuem, como as únicas telhas de zinco, a maior caixa de som, as voadeiras da FUNASA, o cortador de grama, etc. Não se trata de uma prerrogativa sua, já que muitos possuem bens exclusivos, mas, antes, um acordo entre agentes externos, que tendem a dar coisas aos "caciques" e os próprios indígenas que esperam que um patarahu seja mais poderoso que os outros. Isto não significa que eles acumulem mais que os outros, embora, geralmente, tenham casas maiores, a questão parece ser a capacidade de controlar e distribuir bens/poderes obtidos da alteridade. Se receberem um pacote de café de algum branco que passa pela aldeia, aqueles que quiserem poderão tomar um pouco em sua casa (como em qualquer casa que em dado momento tenha café), mas, se receber grande quantidade, irá distribuir aos outros e procurará, sempre, fazer essa intermediação.

Essa capacidade mobilizada pelo patarahu é a mesma que possuem os kariva patarahu. Não é sem razão que os chefes Deni parecem ser capazes de utilizar o trabalho de outros moradores da aldeia sem que seja necessária uma contrapartida imediata, enquanto que as pessoas comuns só conseguem apoio para suas empreitadas caso forneçam, invariavelmente, uma refeição aos participantes, no mesmo dia em que realizam a tarefa. Não é que haja algum poder que constranja os outros a trabalharem para os chefes, mas, antes, parece haver um sentimento de que se fazem parte da turma/fregueses $\left(k e p e i^{129}\right)$, devem fazer o que é requisitado. O trabalho, contudo, não é

\footnotetext{
129 Azevedo (2007) aponta que fregueses seria kurumideni, mas nos pareceu mais frequente o uso do termo kepei do que kurumideni para se referir ao conjunto dos fregueses e empregados. O par relacional é formado por patarahu/kurumi (_deni é um sufixo que indica plural de coisas humanas), mas um patrão tem, necessariamente, mais de um empregado, portanto, é possível que kurumideni seja a forma como determinado patrão se dirige a todos os empregos, já kepei seja a forma de referência ao conjunto como um todo. Quando falam patarahudeni os Deni ou se referem aos donos de comércios como um todo, ou aos chefes das aldeias, podendo ser que, kurumideni corresponda, por sua vez, a todos os que são empregados, independente de quem seja o patrão de cada um. Kepei é um termo utilizado para sinalizar,
} 
mobilizado para qualquer fim, por exemplo, eles não fariam um roçado para sua família, mas constroem uma casa que além de habitação deverá servir como local de reunião com os brancos que passarem pela aldeia.

Outras posições e poderes do universo dos brancos também foram sendo apropriadas pelos Deni. Dizem que um Deni que saiu da aldeia com os brancos, voltou anos depois para a região e desapareceu novamente após algum tempo, se transformou soldado durante sua primeira ausência da região. Os agentes de saúde e professores são os exemplos contemporâneos mais evidentes, os primeiros obtiveram acesso regular ao dinheiro disponível nas cidades e aos remédios, os últimos, além do salário, recebem anualmente papéis, canetas, e outros materiais escolares e, também, ocasionalmente, grandes quantidades de alimento.

É interessante notar que os Deni não parecem associar a obtenção destas posições/fontes de renda como constituindo uma contrapartida a um trabalho que devem realizar, e sim como fontes de dinheiro disponíveis aos brancos, obtidas após a assinatura de um contrato. Como relatou um dos professores, foi um dos missionários que escutou uma coisa muito boa na cidade, que queriam fazer contrato e dar dinheiro para os Deni. Ele ensinou alguns a assinarem seus nomes e, assim, eles puderam ir para a cidade, assinar os contratos e passar a receber o dinheiro. Nas aldeias, a atividade docente só parece acontecer nos períodos em que é enviada a merenda, o que ocorre uma ou duas vezes por ano. As outras pessoas da aldeia têm a ideia de que as merendas devem ser amplamente distribuídas, pois os professores usam seus nomes para consegui-las.

Um dos professores relatou, em mais de uma ocasião, que na cidade os kariva ganham muito dinheiro para trabalhar com papel, apontando os funcionários da secretaria municipal de educação como exemplo de pessoas que ganhariam muito dinheiro para trabalhar com papel e com o computador. A situação dos professores indígenas, por sua vez, seria diferente, já que seriam remunerados apenas durante oitos meses por ano, devendo, no início de cada período, assinar um novo contrato e entregar um papel com a lista de seus alunos. A cada ano, eles temem que não seja feito um novo contrato e eles parem de receber, parecendo seus pequenos salários (do seu próprio

negativamente, o conjunto dos amantes de alguém que namora muito, quando dizem, por exemplo, que uma moça kepei.a.ru, que quer dizer algo como, "ela fez uma turma", indicando que ela é namoradeira, logo não é boa para casar. 
ponto de vista) condicionados a escrever seus nomes nos contratos apenas uma vez ao ano.

Os Deni sempre atribuem a si mesmos uma posição em que estão na boa medida das coisas, representando sempre de forma negativa qualquer um dos extremos aos quais se comparam. AISs e professores, apesar de terem acessado essas fontes de renda, não deixam de afirmar que eles têm que trabalhar, isto é, plantar roçado, caçar, pescar e que morreriam de fome se quisessem ficar como os kariva da cidade, que comem sem produzir seu alimento. Quando pensam a respeito dos ribeirinhos, apontam que estes trabalham muito mais que os Deni, mas, no lugar de constituir-se como um valor, isto acaba sendo associado com um desejo de consumo, ilustrado pela seguinte fala:

A cultura do karika é ficar velho com 30-35 anos. Pode/tem que trabalhar para sustentar a esposa. Mulher branca precisa de muito. Com essa idade o homem branco já pode casar. Madiha não precisa de nada, por isso casa logo. Não sabe fazer casa e não sabe fazer roçado, mas casa. [...] O branco é diferente. Ele pensa no dinheiro, para comer, para comprar coisas para a mulher e pra viver. Os madiha são diferentes. A mulher deni não precisa de nada, não reclama de nada com o marido.

Esta visão não se limita apenas aos kariva, comparando-se com as próprias populações indígenas da região, os Deni jamais ocupam os extremos, situando-se sempre entre os Suruwahá, que só aos poucos estariam conhecendo e absorvendo os poderes controlados pelos brancos, e os Apurinã que, ao assumirem estes poderes (os Deni mencionam que há Apurinã que são seguranças, motoristas, enfermeiros, funcionário da FUNAI), acabaram sendo como os brancos. O único continuum em que os Deni, a despeito de todos os outros seres do cosmos, se colocam em um dos extremos é o da violência. Os Deni são pacíficos, enquanto qualquer representante da alteridade é imbuído da agressividade e tendência a matar os outros. Os Deni consideram que possuem esta disposição, mas seriam aqueles mais capazes de controlá-las.

Sempre prontos a afirmar que nunca mataram um branco, os Deni sempre relatam que seus ancestrais possuíam disposições violentas, eram valentes (bukede ${ }^{130}$ ), mas, além de não narrarem os episódios violentos que envolvem seus parentes, afirmam

\footnotetext{
${ }^{130}$ Há entre os Deni dois verbos que poderíamos traduzir por briga: bukebuke_e vakhavakha_. O primeiro seria uma briga que poderia levar a morte, já o segundo seria uma briga que não levaria a morte de ninguém, por exemplo, no primeiro caso estaria uma briga com terçados e no segundo uma de socos.
} 
que abandonaram as disposições guerreiras após o convívio com os brancos (especificado como Paulo Mourão por alguns). Os Suruwahá, ainda, conservariam esta disposição abandonada pelos Deni, mas os Marima ${ }^{131}$, que não têm qualquer contato com os brancos, seriam mais violentos que os Suruwahá, que teriam medo deles. Apesar disso, um branco teria matado alguns Marima para ter relações sexuais com uma moça desta população. Nesse cosmos onde todos matam todos, os únicos que não o fazem, mesmo quando são vitimas de ataques não há vingança, são os Deni.

Como já apontou Azevedo (2007) os zuphinehedeni (os xamãs) são os únicos Deni que permanecem com disposições assassinas, mas, eles próprios não são mais alvos dos assassinatos que ocorriam no passado e puniam aqueles que causavam muitas mortes. Os xamãs são, ao mesmo tempo, fonte de vida e de morte, da mesma forma ambígua como são os próprios kariva, que podem ser bons ou maus, generosos ou sovinas, mansos ou valentes, aliados ou inimigos. Ambos são detentores de poderes dos quais os Deni precisam se valer para continuar seu desenvolve-gente e as melhoras em seu modo de vida, mas a relação com eles representa um risco, já que, o primeiro, conforme adquire poder, perde a sua humanidade e o segundo é humano, apenas, no limite.

A questão da humanidade entre os Deni é muito complicada. Madiha ou madi poderia ser considerado como correspondendo aos humanos, o que excluiria os kariva que nunca são madi ou madiha. As queixadas ${ }^{132}$, porém, são madi, enquanto nenhum outro animal o é. Durante uma conversa em português, um dos professores, cujo avô era kariva, dizia que os brancos também são "gente", passando a listar partes do corpo que comprovariam a sua humanidade, isto é, os kariva seriam gente porque o formato do corpo deles seria o mesmo. Dado que parte significativa da população Deni conta entre seus ascendentes um homem branco, e que pela teoria da concepção Deni todos os seus ágnatos seriam também kariva, haveria um problema em negar totalmente a humanidade dos brancos.

Até o momento, apontamos como os kariva aparecem aos Deni e como estes pensam a aquisição das coisas dos brancos, sem levar em conta como os madiha veem a si mesmos. Os brancos se fazem presentes mais do que seria esperado no cotidiano

\footnotetext{
${ }^{131}$ A referência bem como as histórias que os envolvem foram obtidas junto aos brancos e tratariam possivelmente dos Hi-Merimã.

${ }^{132}$ Entre os Kulina, Pollock (1985) afirma que as queixadas são usadas como metáfora para os humanos.
} 
Deni, sendo impossível considerar outros aspectos da cosmologia sem ter antes a noção de quem são os kariva e de como surgiram. Podemos, agora, considerar apropriadamente o universo Deni e suas relações internas. Passamos a descrever agora a história Deni sobre eles mesmos, visando entender a forma como lidam com a alteridade, o que tornará claro muitos comentários feitos até o momento de forma abreviada. 


\section{Capítulo 2 - Madihadeni}

Neste capítulo, iremos apresentar a visão dos Deni sobre eles mesmos, analisando algumas narrativas novas e fazendo referências àquelas discutidas no capítulo anterior. A partir da consideração de alguns relatos, será possível estabelecer as mudanças pelas quais passaram seus antepassados e que resulta na configuração atual. Em seguida, teceremos alguns comentários sobre a sociologia Deni, considerando as formas como estes estabelecem coletivos humanos e não gumanos. Por fim iremos considerar a forma de estabelecer coletivos em certas partes do cosmos que envolvem pessoas e animais.

Utilizaremos, enquanto uma ferramenta descritiva, os modos relacionais (relational modes) de Descola (2012). Isto não quer dizer que aderimos às suas ideias sobre o animismo ${ }^{133}$ como uma forma de identificação entre humanos e não humanos que resulta da projeção da sociedade humana sobre os coletivos não humanos. No debate entre Descola e Viveiros de Castro, acreditamos que os Deni tenderiam a concordar mais com este último, vivendo num mundo antropomórfico em que "todos os seres têm a forma humana e são humanos para si” (Maizza 2012:32). A diferença entre seres deve-se a perspectiva que está relacionada aos seus corpos, sendo que apenas os xamãs (seja um Deni ou um anta), graças à presença de katuhe (pedra-poder) em seu corpo, podem ver todos como humanos. Isso fica evidente ao se considerar as relações que os Deni afirmam existir entre o triângulo cobras (makha), humanos (madiha) e antas (avi).

As makha, cuja manifestação visível, que os brasileiros chamam de cobra, são as armas das entidades makha, são invisíveis aos não-xamãs. Elas são madiha que veem as pessoas como se fossem antas, as aldeias como se fossem barreiros e, tal como os caçadores, ficam animadas ao verem marcas de pés/patas recentes em algum caminho. As cobras e antas, por seu turno, se veem da mesma forma, pois as cobras são invenção/criação da esposa-mãe da anta, uma criança humana que foi levada, criada e desposada pelo Anta, ou seja, do ponto de vista de ambos elas não se distinguem e vivem nas mesmas aldeias: os barreiros. No processo de curar uma picada de cobra, o xamã Deni transforma o caçador atacante em uma anta, garantindo a sobrevivência da

\footnotetext{
133 Para uma discussão sobre os modelos do "animismo sociocêntrico" de Descola e o "animismo perspectivista” de Viveiros de Castro, veja Maizza (2012).
} 
pessoa que foi mordida, pois esta deixa de ser uma presa, isto é, as perspectivas (Lima 2005) são invertidas e o doente pode se restabelecer.

Quando mata uma anta com apenas um tiro, o caçador Deni diz: "eu sou zumahi makha", uma espécie de cobra tida como muito agressiva e cuja picada é geralmente fatal para os humanos. O ataque certeiro leva os Deni a se identificarem com um não humano reputado como grande matador, tal como chefe Cunhambebe que se tornava onça durante o festim canibal Tupinambá (Staden 1974). A identificação entre os Deni não se limita aos casos em que ocorre um tiro certeiro, de maneira geral a letalidade do ataque se apresenta como indício de qual espécie de cobra a pessoa é. Aquele que não mata é zuni, uma cobra não agressiva, de picada fraca e sem veneno.

Não se trata de uma identificação metafórica, o caçador não é como determinada espécie de cobra, ele será identificado enquanto tal, quando o xamã anta for tratar a sua presa, que retornou doente para a aldeia do barreiro após ter sido atacada. Nesse esquema são os Deni e não as cobras e antas que são apreendidos de forma variável, ou seja, são eles que, dependendo da relação, serão cobras ou antas, já cobras e antas são sempre humanos para si e entre si. Os Deni são incapazes de visualizar as cobras propriamente ditas e apenas ocasionalmente conseguem ver uma de suas armas durante um ataque ${ }^{134}$, já os xamãs só as veem como humanas. O protótipo do caçador são as cobras e não os Deni, a anta, quando cria as cobras, não cria propriamente outros seres, mas faz armas que, de certa forma, forçam as suas cobras (os Deni que mataram seu marido e filho) a assumir a sua perspectiva, isto é, se os humanos/Deni eram os predadores (e como mostraremos a seguir essa é a posição Deni inicial) a existência das cobras vai fazer com que eles sejam antas, ou melhor, humanos/antas predados na relação com as cobras.

Retomemos os modos relacionais de Descola antes de continuar com nossa descrição. Este autor apresenta um grupo com seis tipos de relações que parecem desempenhar um papel preponderante nas conexões que os humanos estabelecem uns com os outros e, também, com os elementos não humanos do seu ambiente (Descola 2012: 448). Desses seis tipos, três poderiam ser usados para descrever os movimentos da história Deni. Estes seriam os modos relacionais de troca, predação e dádiva, que tratam de relações potencialmente reversíveis entre termos que são similares; os outros

\footnotetext{
${ }^{134}$ Algumas picadas de cobra não são visualizadas pelos não-xamã, que apesar de sofrerem seus efeitos, não conseguem enxergar qualquer marca superficial na pele.
} 
(produção, proteção e transmissão) diriam respeito a ligações entre termos hierarquizados e não equivalentes.

Troca, predação e dádiva envolvem o movimento de algum valor entre dois termos ontologicamente semelhantes, podendo eles próprios corresponder ao que circula, isto é, eles podem transferir a si mesmos e desaparecer fisicamente. A troca é uma relação simétrica, em que a transferência de uma entidade para outra requer, necessariamente, algo em retorno, isto é, a obrigação de haver uma contra prestação é explícita. As outras duas são assimétricas, a transferência é de apenas de uma das partes para a outra, seja através da entrega livre sem necessidade de retorno: a dádiva com assimetria positiva; seja pela tomada de algo sem esperar que haja um pagamento: a predação com assimetria negativa.

Como chama a atenção Descola, dois destes termos possuem uma longa história na tradição antropológica, sendo necessários alguns comentários adicionais a respeito da forma como eles serão aplicados ao longo deste capítulo. Tentando se diferenciar de Mauss, para quem a dádiva representa o momento inicial de uma troca recíproca, Descola aponta que a dádiva não torna obrigatória uma contra dádiva, trata-se, ao contrário, de uma transferência em que não se pressupõem nada em retorno. Aquele que fornece um presente não espera nenhuma forma de compensação, pode haver um novo presente que inverta a posição daquele que dá e do que recebe, mas o valor transferido inicialmente não é sua causa e sim motivações de outra ordem.

Para Descola isto é diferente da troca, na qual o que é inicialmente transferido trás como obrigação algo em retorno, ou seja, os dois movimentos são causa e efeito um do outro. Na troca há uma obrigação de contraprestação sobre o valor inicialmente transferido; não se trata de duas ações isoladas de dádiva, mas de uma relação que envolve duas transferências em direções opostas para se concluir. Os termos estão, necessariamente, em uma relação reciproca que só se realiza após as duas operações, sejam elas simultâneas ou separadas no tempo. Não é a reciprocidade que a define, mas a obrigação de retribuição que em alguns casos exclui a reciprocidade.

Nos outros dois modos não há obrigações envolvidas, na dádiva dá-se sem esperar algo em retorno, já na predação toma-se desejando que não haja retaliação. As expectativas mudam conforme um ou outro modo está em operação. Na dádiva há uma transferência na qual o termo que sede algo, que pode ser a própria vida, não implica o 
que recebe a realizar uma contra dádiva, esta pode ou não ocorrer, mas, se existir, ela não terá como causa o presente inicial. $\mathrm{Na}$ predação, não se oferece qualquer compensação por aquilo que é tomado. Essa falta de contrapartida não implica um desejo de prejudicar/machucar ou alguma necessidade fugaz (Descola 2012: 455), mas um modo de relação em que ocorre a incorporação de algum valor a partir daquele que o recebe e não do que cede, como ocorre no caso da dádiva.

Esses modos irão nos auxiliar no entendimento da relação Deni com a alteridade e a forma como são recortados os coletivos. Entre os primeiros momentos e os dias atuais uma série de diferentes relações foi estabelecida com os Outros, ou seja, diferentes tipos de coletivos foram surgindo no $\operatorname{cosmos}^{135}$, a medida que passam a se constituir como termos das relações cosmológicas. Não se trata de um simples processo em que ocorrem mudanças na forma como os Deni se relacionam com a alteridade, mas, antes, um desenvolvimento que fundou (e ainda funda) personagens diferenciados no cosmos. De início, toda a diferença se apresentava enquanto inimigos, a única relação com os Outros era a guerreira.

\section{1 - O tempo da violência}

"Antigamente os Deni eram valentes. Viam alguma coisa ou pessoa e queriam matar". Esta ideia era comumente expressa por um Deni para tornar inteligível o comportamento dos homens nos primeiros tempos. Toda relação com a Diferença era uma relação guerreira, em que todo encontro com o desconhecido é o prenuncio do conflito. Não sem propósito nos relatos situados no tempo inicial, isto é, anteriores a diferenciação humana, os Outros sempre aparecem de forma muito marcada, seja possuindo formas grotescas, emitindo sons de animais, ou mesmo possuindo traços aperfeiçoados. Estariam aqui, por exemplo, as narrativas sobre o surgimento dos piuns (bitha) e da água.

Se considerarmos uma gravação sobre o surgimento dos piuns, narrada em junho de 2010, isto se torna evidente. O próprio início já marca as disposições violentas dos primeiros humanos, como nos trechos que transcrevemos a seguir:

\footnotetext{
135 Devemos salientar, tudo que dissermos, aqui, diz respeito à visão Deni a partir do momento da pesquisa de campo: 2010-2012. Os momentos iniciais da humanidade são aqueles apreendidos a partir do presente e surgem em relação a este.
} 
Antigamente índio não podia ver nada. Via uma coisa e matava. Via um sapo, matava. Via uma cobra, matava. Via uma coisa, a gente matava.

Antigamente não existia pium. Não existia mesmo.

As pessoas foram caçar. Lá na beira do igarapé, do lago, não sei. Ouviram gente, gente mesmo, que nem nós. Tinha uma rede atada em cima do rio. Ele estava cantando, falando.

- Eu vou pra baixo, eu vou pra cima. Eu vou pra baixo, eu vou pra cima. Eu vou pra baixo, eu vou pra cima.

Quando o caçador chegou lá ele escutou. Ele balançava na rede cantando. O caçador chegou na beira.

$[\ldots]$

Ele não foi lá não, ele foi pertinho. Chegou bem perto e voltou para trás. Foi embora para casa. Quando chegou lá, 18h, ele avisou todo mundo.

- Escutem. Hoje vi um animal que era igual gente. A maqueira [rede] atada no meio do rio. Ele começou a cantar falando: 'eu vou pra cima, eu vou pra baixo'. É gente mesmo, tinha a barriga muito inchada, era bem baixinho. Eu vi, mas não falei com ele. Fiquei com medo e vim embora. Podia acontecer algo comigo, o bicho ia me matar, fiquei com medo, por isso vim embora. Amanhã vamos ver. Todo mundo, vamos ver como é o bicho, como parece. Vamos amanhã olhar.

Dormiram. De madrugada começaram a fazer flecha envenenada, cacete, pau para arpoar. Saíram todos armados. Chegaram na beira. Ele estava rindo, do lado das pessoas.

- O que vocês vieram fazer aqui? Vocês vieram pra me matar ou só pra me visitar? Se vocês estiverem com raiva de mim, podem tapar os buracos do meu nariz, da minha boca, tampar meu anus. Tampa todos os meus buracos. Tampa tudo, minha orelha também. Ai pode me matar, senão todos vocês vão morrer. Não vai escapar nenhum vivo.

Ele avisou. Todos pararam. Ficaram de olho, todos armados com flecha, cacete, pau. Ficaram olhando. O nome dele era pium. Ele avisou: 
- Meu nome é Bithamadi. Eu sou dono do pium.

Ele era buchudo. Pium, mutuca, mutuca preta, tudo estava dentro.

Tinha um homem apressado. Ele chegou depois. Ele era mal.

- Vocês ainda não mataram esse bicho. Ele pode matar vocês!.

Outro disse: - Não

E puxou o braço dele para trás. Mas ele não acreditou.

- Me deixa matar.

Puxou de novo para trás.

- Não mata.

- Você faz assim...

Ele furou a barriga. O bicho gritou - Ai!.

A mutuca começou a zoar. Os piuns saíram pela boca, pelo nariz, pela orelha, pelo anus, por todos os orifícios do corpo. Saíram pium, mutuca, mutuca preta e todos os tipos de mutuca e voaram em direção ao pessoal. Eles iam matar.

- Vou matar vocês, porque sou o dono da mutuca e pium.

As pessoas correram, mas os bichos eram mais rápidos. Chupavam o sangue todo da pessoa. Dois rapazes tinham ficado longe, cismados. Eles começaram a correr, todos os outros foram mortos. Eles sentiram o cheiro de pessoas e seguiram. Tinham quatro comunidades, aldeias.

A narrativa continua com a destruição de quase todas as aldeias até que, na última, um xamã consegue levar os piuns para o céu. A primeira metade do relato é suficiente para ilustrar as disposições guerreiras iniciais dos humanos. Todos os protagonistas querem matar uns aos outros e tal relação potencial é dada logo de início. Não há, aqui, nenhuma forma de predação em atuação, a morte do inimigo não sendo parte de um esquema de incorporação da diferença e sim o resultado de um encontro casual.

Esse mesmo esquema esta presente na história do surgimento da água e dos rios, que não valeria a pena considerar na integra. É a seguinte: As pessoas ouviram o coaxar 
do sapo Turatura e viajaram alguns dias até encontrarem a origem do barulho. Viram uma mulher que, sabendo que seria morta, instruiu os humanos sobre a forma correta, mas, tal como aconteceu com Bithamadi, as instruções não foram respeitas pela pressa que tinham em atacá-la. Toda diferença situava-se aqui no campo dos inimigos, cuja única relação possível era a destruição violenta, mesmo que as vítimas possuam disposições de certa forma benéficas, já que alertam sobre a forma correta de serem mortas, nem suas palavras são incorporadas pelos Deni.

Seria interessante notar que o surgimento da água, que em realidade é apreendido como algo benéfico, já que todas as versões que obtivemos em campo se iniciam por considerações a respeito da dificuldade de uma vida na qual o único líquido disponível era a urina, apresenta muitas ambiguidades. Das duas variantes que obtivemos no Cuniuá, uma delas salienta que o resultado imediato da morte é uma enchente que afoga uma grande quantidade de pessoas, já a outra menciona, apenas, o surgimento dos rios, lagos e igarapés. Talvez, seja nessa primeira apropriação de algo da alteridade, isto é, o surgimento da predação como modo relacional, que esteja o real motivo para que ela seja situada como o evento inicial da história Deni, como mencionado no capítulo 1 .

Na coletânea de mitos do Xeruã (Sass 2004: 28-29), o surgimento da água corresponde a segunda metade de uma narrativa que aborda inicialmente o surgimento do fogo. Em resumo, a narrativa estabelece que, inicialmente, os Deni comiam carne seca ao sol. Um dia encontraram, pela primeira vez, o fogo e ficaram dormindo perto dele que era bem quente. Eles não conseguiram levar o fogo quando foram embora. A Coruja ficou sabendo e foi atrás do fogo. Ela conseguiu obtê-lo queimando algodão quando passou voando em cima do fogo. Depois, ela mesma descobriu como fazer o fogo.

Os Deni foram até sua casa, que era perto, para aprender. Coruja ensinou e recomendou que tomassem cuidados e, no caso de uma criança se queimar, deveriam apagar o fogo com água. Uma criança se queimou e morreu. Ainda não havia água para controlar o fogo (e para cozinhar), então usaram a urina. Os Deni resolveram procurar a água pelo mundo, até que um homem escutou o coaxar de um sapo muito longe. Foram até ele que reconheceu que seria morto, mas não fez nenhuma recomendação especial. O sangue do sapo se transformou em igarapés e rios. 
A versão do Xeruã situa a obtenção do fogo e da água numa transferência de valores entre diferentes, a primeira no modo dádiva de Descola, a segunda no predação. Ela se situa em uma chave interessante, pois, embora tematize, não trata apenas do modo como surgiram os rios e igarapés. O que está em questão é o surgimento do fogo culinário, já que o fogo obtido junto a alguém perto teve de ser controlado por um elemento obtido muito longe para se tornar aquele que cozinha e não apenas o que queima e mata. No primeiro contato com o fogo, ele passa a agir como um inimigo, o conhecimento sobre a forma de dominá-lo deve-se a um aliado ${ }^{136}$, alguém que morava perto. A coruja não apenas descobre a existência do fogo por intermédio dos Deni, mas, após descobrir a forma de torná-lo fogo culinário, transmite a estes a necessidade de estabelecer uma relação de predação, isto é, se apropriar do sangue/água do sapo para passarem a comer cozido ${ }^{137}$.

Os momentos mais distantes do tempo presente Deni são marcados pela negação da diferença, isto é, o "Nós" só teria como relação possível a destruição do "nãoNós" ${ }^{138}$. É notória a falta de termos de parentesco nestas narrativas, seus protagonistas não mantêm entre si qualquer relação definida, a divisão sendo, quando muito, entre os parentes indiferenciados e os não parentes. A noção de um conjunto de semelhantes a mim seria expressa pela palavra que os Deni geralmente traduzem para parentes: "uvibuva" (meu parente, plural uvibuvadeni), existindo as formas para meu, seu (tivibuva) e dele (ibuva).

O uso de uvibuva é variável, abarcando consanguíneos próximos em seu limite mínimo e todos os Deni, quase avançando para todos os indígenas, no máximo. Estes últimos são chamados de 'parente' em português durante as conversas em deni, mas são postos junto aos parentes (no termo da língua deni - uvibuva) em resposta a inquisição se determinado indígena é um parente do ouvinte (tivibuva). Até onde vão nossos conhecimentos, não há um termo específico para indicar propriamente aqueles que não são parentes, sendo expresso apenas enquanto uma negativa.

\footnotetext{
${ }^{136}$ Embora esta seja uma narrativa do Xeruã, é interessante que ela se assenta ao que dissemos no capítulo anterior. A história Deni é baseada num progressivo domínio de conhecimentos pertencentes aos Outros e que são apropriados depois que se tornam aliados.

${ }_{137}^{137}$ Nossa visão sobre o culinário é influenciada em grande medida por Lévi-Strauss (2004 [1964]).

${ }^{138}$ Não parece haver termos para diferenciar "Nós" e "Eles", isto é, não parece haver pares de termos que expressem um conjunto formado por semelhantes e um conjunto dos diferentes. Claro que existem os pronomes "nós" e "eles" e essas ideias de conjuntos podem ser expressas na língua, mas elas parecem não ter grande relevância na sociocosmologia Deni.
} 
Nas narrativas do primeiro tempo, os protagonistas são conjuntos de parentes. Por exemplo, na história do pium, aquele que avista primeiramente o monstro vai se dirigir aos seus com o vocativo uvibuvadeni (meus parentes). O diálogo entre o monstro e os humanos, por sua vez, não passa por qualquer menção a relação entre eles. Esta conversa, na versão transcrita por Sass, é introduzida pela construção verbal: Pua'a tupiniza imanari (2004: 34), que numa tradução literal é: 'ele [o monstro] falou para eles [os humanos] ${ }^{139}$, seguido pela recomendação na forma de matar.

Não temos, aqui, a inimizade como fundante de uma relação produtiva entre o matador e sua vítima (Viveiros de Castro 2002), não se trata de predação propriamente dita. Temos um contexto inicial, a partir do qual a relação com a alteridade foi sendo construída, de forma a serem obtidas as potências que levaram às melhoras na condição humana. Acima mencionamos uma das narrativas do Xeruã em que, num contexto de multiplicação e divisão dos Outros em aliados que moram perto (Coruja) e inimigos que moram longe (Sapo), as relações com as alteridades podem assumir um aspecto positivo. Nosso conhecimento das narrativas em circulação no Cuniuá não permite demonstrar essa associação entre a marcação genérica de um grupo de parentes indiferenciados (uvibuva) e grupos diferenciados da alteridade com a obtenção de potências cósmicas entre os Deni dessa região.

Podemos dizer, contudo, ainda no contexto na primeira humanidade, que eventos muito semelhantes àqueles ocorridos quando do surgimento do pium e da água, mas que se passam no momento em que as relações de parentesco já estão constituídas, resultam na incorporação de poderes externos. No relato sobre o encontro com Zanikuva (Jabuti), que carregava dentro de si os animais de caça, temos os elementos presente nos dois acontecimentos que viemos considerando até agora: um monstro emitindo barulho atrai os humanos; o encontro trás a expectativa de que ele resultará na morte de alguém e; o monstro faz recomendações a cerca de sua morte. Há, contudo, uma grande diferença em sua resolução como é possível apreender a partir das suas linhas gerais.

Um homem sempre caçava com zarabatana, mas voltava para casa sem carne. Um dia ele foi pelo seu caminho, imitou o som do macaco prego e começou a ouvir um barulho alto, acompanhado de muito vento e escuridão.

\footnotetext{
${ }^{139}$ Pua'a - pronome masculino de $3^{\text {a }}$. pessoa singular. Tupuniza (tupuni - pronome $3^{\text {a }}$. pessoa do plural quando é objeto direto [eles], _za indica alvo da ação). Imanari (ima_na - falar, a $3^{\mathrm{a}}$. pessoa dispensa o uso de partícula indicativa de sujeito; _ri - indica ação recém-completada ou em curso por sujeito masculino de $3^{\text {a }}$. pessoa).
} 
Assustado ele voltou para a aldeia. Seu cunhado $^{140}$ perguntou sobre os acontecimentos e dizendo que era corajoso resolveu ir ao encontro do monstro.

Ele fez como o outro homem, mas, invés de correr, empunhou seu arco e esperou. Começou a ouvir alguém dizer repetidamente: Eu estou cansado. Avistou Zanikuva, um jabuti gigante, que pediu para não ser morto: Meu neto, não me mata. Ela disse para o homem fazer certos preparativos para quebrar seu casco na região das $\operatorname{costelas}^{141}$ e pegar dentro dela um ovo grande no qual estavam os bichos de caça. Seguindo a orientação do jabuti ele tira o ovo certo e não o pequeno que continha onças, cobras e outros animais predadores. Pela utilização correta do ovo o homem consegue caçar muitos animais, que sempre apareciam perto dele.

As noticias sobre suas façanhas chegaram à outra aldeia e um de seus cunhados foi tentar descobrir o que acontecia inquirindo a esposa do caçador. Após grande insistência ${ }^{142}$ o possuidor do ovo contraria as recomendações do Jabuti e divide o ovo, mas, após entregar a metade para o cunhado, não ensina a forma correta de tornar o poder ativo novamente. Como resultado o poder de caça se perde e hoje em dia só encontram poucos animais e sempre longe.

No universo composto apropriadamente por parentes, há, pelos menos, relações entre avó/netos, entre cunhados e de cônjuges, as relações com a alteridade passam a ser positivas. Nesse contexto a alteridade não deve ser eliminada, já que a relação estabelecida com ela é benéfica, permite a incorporação de valores não possuídos anteriormente, e é a relação com a afinidade que leva a sua perda. Não há, aqui, uma clara definição do modo relacional em atuação na interação com o Outro, podemos assumir que houve uma dádiva do Jabuti para o caçador ou que houve predação, já que não há uma simples entrega.

No processo de incorporação do poder de caça, se fez necessária a morte limitada do jabuti para que ocorresse a transferência, mas esta poderia ser pensada

\footnotetext{
${ }^{140}$ No diálogo, os protagonistas se chamam de ukheve na maioria das versões de que dispomos, termo que os Deni afirmam ser a forma antiga de tratamento entre os cunhados, atualmente abuni. O termo abuni, por sua vez, não é muito utilizado entre os Deni, que preferem utilizar kunadu (cunhado), kupadi (compadre) entre si e reservar abuni para as relações interétnicas.

${ }^{141} \mathrm{O}$ local indicado, geralmente com as mãos, é a lateral do peito, embaixo do braço. Este seria o melhor ponto para alvejar um animal de caça, pois causaria sua morte com apenas um ataque.

${ }^{142} \mathrm{Em}$ algumas versões o homem fala inicialmente com a esposa do caçador, a quem aplica o termo uvini (cunhada, esposa potencial).
} 
enquanto uma troca, já que o jabuti, segundo muitas versões, demanda determinado tipo de lança e recusa outros materiais. Os materiais, contudo, servem para garantir que a morte seja limitada, pois o caçador deveria acerta o jabuti no ponto mais mortal possível. Parece que o que está sendo colocado, mais uma vez ${ }^{143}$, seja que o entendimento verbal possibilita a não violência, já que ao escutar e seguir as instruções da vítima, isto faz com que o encontro não resulte na morte definitiva do jabuti. A comunicação permite superar a guerra e estabelecer uma espécie de troca.

O importante é que, nesse encontro não guerreiro com a alteridade, foi possível a obtenção de conhecimentos e poderes que ela domina. Há, aqui, certa semelhança com o relato sobre o primeiro encontro com os brancos no Cuniuá, analisada no capítulo anterior. Um encontro potencialmente guerreiro acaba dando lugar a transferências após as partes se comunicarem. Estas narrativas indicam a possibilidades de estabelecerem relações diversas com a alteridade, o que ocorre a partir do momento em que as diferenças são internas aos humanos, ou seja, quando há relações diferenciadas de parentesco, e não um conjunto genérico de semelhantes, de parentes, não é necessário eliminar a diferença, podendo ser obtidos os valores que elas possuem. É nessa chave que podemos entender porque com os kariva ${ }^{144}$, embora a troca seja o modo relacional padrão, ora se preda, ora se dá, eles são o contraponto máximo aos parentes genéricos.

Voltemos ao ponto. No princípio, os madiha procuravam anular toda a diferença, mas, a partir do momento em que diferenças aparecem internalizadas ao "Nós", há uma mudança nas relações com a alteridade. Ao passar a compor as aldeias com consanguíneos e afins ${ }^{145}$, estas relações acabam por ser extrapoladas para os outros humanos. Haveria, assim, parentes (uvibuva) e não parentes, ambos, contudo, recortados pelas relações de parentesco consanguíneo e afim. Essa multiplicidade de relações torna o cosmos um lugar povoado por diferentes entidades.

Neste tempo da primeira humanidade, em que ocorre o processo de diferenciação da diferença, o pano de fundo guerreiro se mantem atuante. Teríamos,

\footnotetext{
${ }^{143}$ Veja o capítulo 1. A existência da comunicação permite que os encontros não sejam guerreiros.

${ }^{144}$ Kariva nunca são madi, outras populações indígenas e os próprios Deni sempre são madi, já alguns monstros são madi (por exemplo, o da história do pium é Bithamadi, que traduzem por 'gente do pium') e entre os animais, apenas as queixadas são indubitavelmente madi. Interessante notar que entre os Kulina há, também, uma forte associação entre humanos e queixadas (Pollock 1985b).

${ }^{145}$ Embora não tenham explicitado isso diretamente, mesmo porque aparentemente não há um termo para designar todos os afins enquanto um conjunto, tenho a impressão de que para os Deni a diferenciação entre consanguíneos e afins funda a politica externa e não a sociedade como queria Lévi-Strauss (1982 [1949]), muito menos a sociologia - que surge com Tamaku e Kira.
} 
aqui, algo semelhante ao mundo em que vivem os Jarawara, no qual há "uma guerra constante, de todos contra todos" (Maizza 2012: 67) em que os inimigos atacam as pessoas em todo o cosmos. Nesse contexto de violência, a predação se desenvolve como modo relacional, os inimigos tornando-se presas, capazes de fornecer poderes anteriormente não possuídos. Predação e violência figuram num mesmo registro sem estarem, contudo, ligadas inexoravelmente, mesmo que, ainda hoje, apareçam associadas em muitos momentos.

Descola (2012) parece ter razão ao afirmar que a exaltação da é uma fantasia projetada por alguns etnólogos nas populações ameríndias. No contexto Deni, a predação surge como o modo de relação em meio à guerra, por isso aparecem em grande medida associadas, contudo, isto não ocorre em todo momento em que a predação está em atuação. Seja em um relato sobre como terçados eram retirados de árvores em que dois estavam amarrados, ou de uma rede de pesca subtraída de um flutuante onde existiam muitas, ou de como uma criança indígena foi levada para ser criada por um branco, etc., em muitos momentos, a predação não se associa com violências de qualquer tipo, ou o desejo de causar o mal àquele que é predado. Os próprios benefícios do INSS parecem se submeter a essa lógica da predação, inicialmente dádivas obtidas pela mediação de um aliado, as rendas agora são apropriadas pelos próprios indígenas. Como já dissemos no capítulo anterior, o dinheiro conseguido pelos indígenas não deixa de carregar em si um perigo, já que pode vir a despertar a violência por parte dos brancos, pois é uma predação, logo se aproxima da possibilidade da guerra.

A caça parece ser o exemplo modelar de quando aparecem inextrincavelmente associadas violência e predação. A caça, nos dias atuais, é equacionada ao ataque xamânico $^{146}$. Ao ser alvejado, dependendo da gravidade do acerto, ocorre uma dissociação entre o corpo e a alma ${ }^{147}$ do animal e, após isto, a alma da presa retorna doente para sua aldeia onde um xamã-animal tentará curar o ferimento, tirando a pedrafeitiço (que para os humanos é o chumbo de caça). No caso de ter sido um ferimento fatal, o caçador irá se apossar do corpo do animal e, quando este for consumido, isto

\footnotetext{
${ }^{146}$ Vale notar que uma associação entre caça e xamanismo também está presente entre os Kulina (Lorrain 1994) e os Jarawara (Maizza 2012). Em ambos os casos, parece que são os xamãs que são associados com os caçadores, isto é, são algumas ações do xamã e seus apetrechos que são semelhantes aos do caçador e não o contrário. No caso Deni, essa associação ocorre a partir da perspectiva dos animais caçados.

${ }^{147}$ Há uma multiplicidade de almas que variam em tipo e quantidade para cada corpo.
} 
causará a morte da presa que irá perecer definitivamente, tal como os humanos falecem quando alguma entidade come ou rasga seu espírito após leva-lo para sua própria aldeia.

Parece haver, entre os Deni, uma relação entre a alma e o sangue, a perda de sangue sendo tomada como um dos indicativos de que uma das almas saiu do corpo. No caso do ataque de cobras aos humanos, dizem que a picada faz sair muito sangue e isto causa a saída da alma da pessoa que se separa do corpo e começa a vagar pela terra. Relações sexuais com mulheres menstruadas resultam no surgimento de uma entidade formada por almas dos dois amantes, que é o resultado da mistura do sêmen com o sangue menstrual.

Fausto (2002) argumenta que a caça na Amazônia é cercada de regras e prescrições que, quando desrespeitadas, dão lugar a guerra de vingança. O medo de ser alvo de contra predação leva o caçador a tomar certas precauções que evitam que ele, ou algum parente, tornem-se presas. No contexto Deni, não parece haver um grande controle na caça, ou uma tentativa de evitar que ela pareça guerra tanto para humanos quanto para os animais, isto é, que o ponto de vista seja confundido na relação. Parece que caça é guerra para ambos, o importante sendo assegurar que os animais sejam os vencidos na relação.

Apenas a existência de filhos recém-nascidos parece impor algumas restrições na caça, visando garantir tanto a segurança do bebe quanto do caçador que se torna mais vulnerável ao ataque das cobras. Os perigos parecem ser colocados principalmente no consumo, especialmente, quando se mata e ingere o corpo de um animal xamã, reconhecível pela magreza corporal e gordura avermelhada. Embora não seja uma associação explicitada pelos Deni, alguns desses animais apresentam ferimentos resultantes de terem sido atacados em caçadas anteriores, ou seja, provavelmente, tornaram-se xamãs após sofrerem um ataque xamânico (terem sido caçados) que colocou pedra-feitiço (o chumbo) em seus corpos, de forma semelhante aos xamãs humanos. Talvez o problema seja o consumo, pois é isto, e não a caçada, que causa a morte definitiva da presa, ao ser comido o espirito do animal morre.

Não parece haver limitações na caça, muitas vezes mata-se mais do que pode ser carregado de volta para aldeia, ou se abandona algumas caças apenas feridas ou aquelas cujo corpo não foi facilmente encontrado, ou matam animais não comestíveis. O único animal que, segundo alguns, mas não todos, não pode ser morto são as capivaras, cuja 
morte representaria um perigo, mas não saberíamos dizer o motivo. Sua carne não é consumida, mas muitos outros animais não comestíveis são mortos. Nos períodos em que existem estilingues na aldeia, não é raro ver algum adulto utilizar um para alvejar um passarinho que não irá consumir. Apenas os mais velhos parecem consumir os diminutos pássaros que acertam desta forma.

É possível que, anteriormente, houvesse uma maior preocupação com a atividade cinegética, já que semelhante ao que aponta Clastres (1990 [1974]) para os Aché-Guayaki, dizem os Deni que antigamente aquele que matava com zarabatana não podia comer o animal que matou, sob o risco de ficar doente e morrer. Eles fazem referência apenas as mortes causadas por zarabatana, pois seria algo do interior que casou a morte do animal. Eles traduzem este algo por sopro, mas a expressão utilizada é "budi nazukheari", sendo budi o termo para indicar algo interno, interior, profundo, que não fica na superfície (que pode ser da terra: nami [terra] budi, da água: pashu [água] budi, etc.) e nazukheari significa matar (“o interior dele matou”).

Se, anteriormente, havia uma ética nas caçadas, isto não ocorre nos dias de hoje, como fica evidente na grande matança de queixadas ocorrida na década de 2000 e sobre a qual obtivemos um relato casual durante uma viagem pelo rio Cuniuá. Não é incomum que, durante os deslocamentos fluviais, algum Deni recorde e relate, comumente expressando algum grau de entusiasmo, o encontro com alguma caça na região em que o barco esteja passando. Em uma destas viagens subindo o rio, ao atingirmos determinada localidade, um senhor começou a relatar que, algum tempo atrás, sentiu o cheiro de queixadas naquele local. Ele e seus parentes viajavam em duas canos e pararam para caçar os animais. Mataram certo número de animais e resolveram tratar e moquear apenas alguns dos que foram mortos, abandonando os outros onde caíram.

Após atingirmos um local mais acima no rio, em que as margens tornam-se barrancos íngremes, o mesmo senhor passou a relatar o reencontro com o mesmo bando de queixadas ocorrido no dia seguinte. Impedidos de subir para terra, todos os animais estavam presos no barranco. A canoa do narrador seguia na frente e foi a primeira a se aproximar dos animais que passaram a ser executados. Seu irmão, que vinha atrás, chegou algum tempo depois e se engajou na matança, primeiro utilizando seu terçado que caiu na água, depois um machado que também foi perdido e por fim o remo. Todo o bando foi exterminado, mas nenhum dos animais foi levado para consumo, pois já estavam levando os animais moqueados no dia anterior. 
Os animais foram mortos de tal maneira que não é possível estabelecer qualquer forma de ética ou precaução associada. Algumas pessoas (indígenas e não indígenas) que passaram pelo rio, algum tempo após o ocorrido, disseram que era possível encontrar os corpos apodrecidos e sentir o cheiro de morte por muitos quilômetros no rio. Não se tratava de predação, apenas de violência pura e simples, assim, a relação com os animais se constrói, em grande medida, enquanto guerra. Os animais caçados parecem figurar como aqueles com quem os Deni mantêm uma relação de violência, de inimigos, onde pode, ou não, estar presente a predação.

Esse episódio envolveu as queixadas que seriam, como os humanos, madi, mas eles também são os únicos animais que andam em bandos muito numerosos. $\mathrm{O}$ verbo utilizado para expressar a ideia de "matar" (nuve_) queixadas difere do que é utilizado para outros animais, mas é o mesmo utilizado para falar do assassinato de humanos, sendo explicado pelos Deni que o uso desse verbo, tanto para humanos quanto para queixadas, ocorre porque ambos são em grande número. Abandonar caças abatidas, contudo, não é algo excepcional, existem alguns relatos de caçada que indicam que muitos macacos foram mortos e deixados para apodrecer porque um animal de maior porte foi encontrado durante a caçada.

Para os Deni, é o consumo que determina se há ou não predação na relação com a caça. Nesse sentido, é interessante mencionar a explicação para o abandono do consumo da carne de tamanduá bandeira fornecida por alguns dos homens adultos da aldeia Cidadezinha. Este animal era consumido normalmente na época dos velhos (e ainda o seria no Xeruã), mas os mais novos se recusam a comer. As explicações dadas foram de que alguns jovens teriam derrubado um tamanduá de uma arvore e mantido relações sexuais com ele que depois fugiu, ou mesmo que vários tiveram encontros sexuais com diferentes animais da espécie sem matá-los ao final das relações.

Esta transformação de um animal, inicialmente um inimigo, em uma espécie de esposa, isto é, sua conversão em um afim, parece forçar a sua exclusão dos alvos da predação $^{148}$. O que se fez foi excluir o tamanduá da predação, mas não da guerra, porque muitos ainda são mortos, mas comidos apenas por alguns velhos, o que se faz,

\footnotetext{
${ }^{148}$ Acreditamos que esta mesma lógica estaria presente em um diálogo noturno que tivemos com um morador da aldeia Marrecão que, durante sua estadia na aldeia Cidadezinha, dormiu no depósito que havia sido transformado na casa do antropólogo. Em dado momento o tracajá que havíamos obtido uns dias antes estava se debatendo e isso provocou o seguinte diálogo. Zé: Seu tracajá está agitado. Antropólogo: É, minha esposa está querendo "vir pra minha rede". Zé: Não! Ela não é sua esposa, nós vamos comê-la, faz mal ela "ir para sua rede".
} 
aparentemente, com reprovação dos mais jovens. Sem destoar daquilo comumente encontrado na Amazônia, as relações constroem os termos e coletivos com os quais os humanos interagem, fabricando eles próprios no processo. Ao se relacionar com uma entidade como um afim efetivo (Viveiros de Castro 2002), torna-se impróprio que ele continue como presa, com os afins o modo relacional apropriado é o da troca e não o da predação $^{149}$.

Nos relatos sobre o passad, mas que não podemos dizer se estão situados durante a primeira humanidade ou após o surgimento da humanidade atual, estão tematizados os perigos da afinidade quando associada com a predação. Temos diversos discursos que mostram a existência de maridos canibais, ou cunhados assassinos, ou como o roubo de irmãs/filhas torna-se causa ou consequência de conflitos, etc.. Os eventos que cercam o surgimento das cobras se assentam nessa lógica, já que, como dissemos, uma filha raptada para se tornar uma esposa (predação) torna-se criadora das cobras, cuja fabricação teve por objetivo vingar a morte de seu marido contra seus irmãos.

Sejam eventos que se situem muito recuados no tempo ou quase no presente, a questão é que predação e afinidade não se assentam muito bem do ponto de vista dos dias atuais. Para os Deni, os casamentos devem ocorrem no modo relacional da troca, chegando ao limite de os pagamentos pela filha/irmã serem iniciados antes do nascimento da mulher. Sem se afastar do padrão amazônico, os Deni consideram o casamento como um processo que se consolida com o serviço da noiva (bride service) e não a transferência de um valor pré-fixado (bride wealth) (Shapiro 1984).

Mesmo que, algumas vezes, afirmem diretamente que o genro deve trabalhar para o sogro e/ou sogra, há certos bens cuja transferência é estabelecida, não é qualquer serviço que se espera do genro/cunhado $(\mathrm{ZH})$. Como dizem: para casar tem que construir casa, dar açaí, patauá e peixe, em alguns casos um roçado, para os sogros. Quando há troca de irmãs, o serviço da noiva torna-se quase inexistente, sendo que, somente, após muitos anos de casado (e muitos filhos) um genro pode se recusar ao trabalho pra o sogro. Um dos homens que se recusou a construir uma casa para o sogro listou, para o antropólogo que o questionou, a quantidade de casas e roçados que deu aos sogros e, pelo que pudemos perceber, quando o casamento ocorre sem ter sido feito

\footnotetext{
${ }^{149}$ E de fato, os animais que são comumente reputados como alvos dos impulsos sexuais dos jovens e crianças são aqueles não comestíveis ou que só se consume em caso de necessidade: jacarés, galinhas, arraias, botos, etc.. Este último, que seria provido de órgãos sexuais iguais aos humanos, deve ser morto antes ou após as relações, senão irá levar a alma do amante quando for embora.
} 
um pedido inicial, isto é, quando se processa de forma semelhante à predação, trabalhase muito mais em comparação com os outros genros. Nos casos de trocas de irmãs, quase não há serviço da noiva.

Na relação com a alteridade, a aplicação dos termos para afins aos kariva e aos outros indígenas se assenta com a noção de que com eles os Deni não fazem guerra, isto é, nunca são os atacantes, embora possam vir a ser vítimas da violência deles. As disposições assassinas dos kariva são evidenciadas nos comentários acerca das brigas que ocorriam na época do extrativismo. Dizem: Kariva amushiaru ninava atihamidepa tupuni nazukheari. Madiha amushiari ninava atihamidepa bukenari. Ambas as construções dizem algo como brancos (kariva) e Deni (madiha) são bons (amushiaru), mas (ninava) se ficam com raiva (atihamidepa)... A mudança está na consequência, quando brancos estão com raiva eles matam (nazukheari), já os Deni brigam (bukenari).

Há três tipos de registros diferentes de relação com a alteridade, isto é, com os diferentes tipos de não-Deni. Com as outras populações indígenas, afins que no limite também seriam parentes (quase uvibuva), a guerra era uma realidade do passado, já com os kariva, ela nunca esteve presente, enquanto com os animais esta era e é a única relação possível. Estes níveis não seriam círculos concêntricos, pois os Deni parecem reconhecer que cada um destes possuiria sua própria visão e atitude sobre o mundo e sobre os Outros.

O pano de fundo sobre o qual se construiu a história das relações com a alteridade é a guerra, o que é formulado pelos próprios Deni que expressam isso ao nomearem esse tempo passado como hamie ${ }^{150}$. Ele se estende desde o início dos tempos até um momento impreciso, funcionando, antes, como um contraponto ao presente do que como uma grandeza absoluta, ora sendo contraposto ao tempo que se origina com o fim das guerras intra-étnicas, ora ao fim dos conflitos com os não-Deni e os brancos. Esse intermédio é justamente aquele que, como dissemos no capítulo 1, está sendo apagado da memória.

Os Deni, ao longo de sua história, foram construindo diferentes identidades e alteridades, partindo de um início em que se tentava negar a diferença, isto é, eliminá-la, construiu-se a predação violenta, que se mantem atualmente com os animais,

\footnotetext{
${ }^{150}$ Hamie, de certa forma, seria traduzível por raiva, como faz o dicionário de Koop \& Koop (1985), mas isso seria algo impreciso. Não temos condições de fazer uma análise semântica apropriada do termo.
} 
possivelmente para evitar que os Deni tornem-se os predados na relação ${ }^{151}$. Frente ao surgimento de outras relações, que permitem a existência de coletivos da alteridade com quem não se mantêm uma relação de guerra, isto é, em que as transferências podem ocorrer em termos pacíficos, os Deni assumem uma postura troquista como base das interações externas. Eles adotaram uma politica externa (voltada para os não parentes) baseada na negação dos conflitos, o que é garantido pelo estabelecimento e manutenção de trocas.

Bonilla aponta que, para os Paumari, haveria três grandes rupturas temporais, associadas a três personagens míticos e que fundam três tempos distintos, cada qual com sua forma de socialidade: o tempo dos antigos; o tempo dos patrões e; a era cristã (Bonilla 2007: 30). O tempo dos antigos é marcado pela guerra, o canibalismo e a doença (: 45), sendo suplantado pelo tempo dos patrões quando os Paumari escolhem a paz. Eles escolheram deliberadamente abandonar as hostilidades em benefício da paz comercial (:85). Os Paumari apontam que, num contexto de violência e predação, eles optaram por abandonar os conflitos em prol de estabelecer um modo relacional de troca com os Outros. A troca, aparentemente, foi eleita como o modo de interação para todas as transferências cósmicas, sendo a forma de se relacionar com todos os tipos de outros, sejam parentes distantes, outros indígenas, brancos regionais ou estrangeiros (Bonilla 2005a: 41-42), ou mesmo os animais. No caso dos animais, diz a autora, "o que aos nossos olhos parece ser comida, carne, presa é na verdade objeto utilitário, alimento préelaborado ou mercadoria... Em troca desses bens, os humanos cedem anzóis, chumbo,

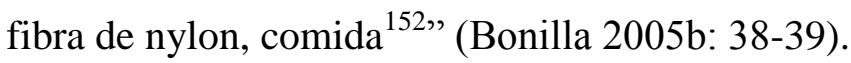

Para os Deni, embora sua história seja semelhante, no sentido de que eles também escolhem progressivamente a paz, a troca não se constituiu como o modo relacional dominante. Como mostramos, aos animais nunca foi estendida a paz e estabelecida a troca, aos kariva, que nunca foram alvo da guerra, a troca é o modo

\footnotetext{
${ }^{151}$ Nesse sentido, é interessante notar que os Deni apontam uma mudança de comportamento em relação as onças. Antes elas eram predadoras, mas, atualmente, ao perceberem sua presença os Deni se armam e correm para cima delas, ao que elas respondem fugindo assustadas. Como conselho ao antropólogo, dizem que se ele fugir a onça vai atrás para matar ele. Fazendo com que a onça se veja como a presa da relação, ela não mata ninguém, mas se assumissem, tal como seria antigamente, a postura da vítima, as onças continuariam a matar os Deni (e o antropólogo).

${ }^{152}$ No contexto Deni, as iscas de pesca também são vistas, pelos peixes, como comida, mas não se trata de um elemento de troca, já que faz parte de uma armadilha. Quando o peixe tenta pegar a isca para por na boca, o pescador puxa a linha fazendo o anzol furar seu dedo ou a boca, o que permite sua captura. $\mathrm{O}$ próprio resultado das atividades de caça e pesca são diferentes, para os Paumari, parece que os animais realmente nunca morrem nesta relação, já para os Deni, o consumo mata irremediavelmente o animal.
} 
relacional padrão desde o principio, embora a predação e a dádiva também participem em menor grau. No universo dos parentes (uvibuva), com quem se exclui o conflito, é a dádiva o modo imperativo. Consanguíneos próximos sempre dão bens sem esperar algo em retorno, aqueles que são sempre uvibuva situam-se no universo da dádiva sem agressão e isto desde o principio. O processo histórico em direção a paz caminhou no sentido de expandir aqueles que estão entre os parentes.

\section{2 - A formação dos Deni e a pacificação}

Como mostramos no capítulo anterior, a humanidade atual, isto é, a descontinua, surge marcada por diferenças linguísticas. Os dois irmãos responsáveis pela recriação dos humanos são responsáveis por estabelecer, por um lado, um grande divisor, isto é, os que são produzidos por Kira são muito diferentes daqueles feitos por Tamaku, dentre os quais se incluiriam os ancestrais dos Deni. Nesse momento o tempo do hamie atinge seu auge, transformando-se na guerra de cada coletivo de gentes contra todos os outros, não somente os possíveis conflitos decorrentes do encontro com a alteridade, mas também os que surgem da relação com os afins. A violência ocorre entre os coletivos localizados em uma aldeia contra aqueles localizados nas outras, a única relação interaldeã é a guerreira.

As narrativas que focam este período envolvem personagens e coletivos nomeados. A descrição dos conflitos em nada se assemelha ao que parece ser o padrão ameríndio $^{153}$, tratam-se de tentativas de extermínio. Não que temas como a vingança, o rapto ou mesmo o canibalismo estejam ausentes, eles só se apresentam de outra maneira. O processo de vingança não forma um espiral em que a posição de atacantes e atacados se intercala indefinidamente, ele aparece como motor de conflitos que idealmente deveriam eliminar o objeto do contra-ataque, ou seja, se há vingança é porque o ataque falhou, gerando como efeito colateral a reação oposta.

A incapacidade de agir apropriadamente, isto é, de exterminar os inimigos, acaba por inverter a perspectiva (Lima 2005), o atacante torna-se vítima de um ataque futuro. No fundo, temos a mesma relação que se dirige atualmente aos animais, em que o caçador procura pela agressividade se manter sempre como predador. O matador ideal

\footnotetext{
${ }^{153}$ Veja Carneiro da Cunha \& Viveiros de Castro (1986) pra o modelo Tupinambá, Cohn \& Sztutman (2003) para considerações a respeito da guerra entre populações Tupi e Jê e Duarte do Pateo (2005) para a região das Guianas.
} 
é aquele que nunca seria vítima, faria sempre a sua perspectiva prevalecer. A narrativa de Banubanu é paradigmática a esse respeito, possuindo larga distribuição no Cuniuá, mas está ausente da coletânea do Xeruã.

Makuturu $^{154}$, a irmã de Banubanu, havia casado em outra aldeia com Kuimakhuvi, um grande guerreiro. Banubanu ficou preocupado com a irmã e perguntou para o cunhado com ela estava. Kuimakhuvi mandou a esposa embora, dizendo que o irmão dela havia pedido o seu retorno. O casal marcou de se encontrar na aldeia de Banubanu após alguns dias, quando o cunhado deveria preparar uma festa.

Kuimakhuvi falou para seu pessoal fazer armas para guerrear. Fizeram flechas, arcos, cacetes. Prepararam veneno para matar. Eram muitos guerreiros com muitas flechas cada um $^{155}$. O irmão do Kuimakhuvi era o chefe da aldeia e ele mandou o seu pessoal caçar e ir aos roçados para fazerem uma grande festa. No dia anterior à partida, fizeram a festa e cantaram as músicas da guerra até o amanhecer. Foram para a guerra, atravessando um rio grande de canoa. Continuaram andando.

Makuturu estava cantando animada, porque seu marido iria chegar. Quando eles chegaram, seguraram os cabelos da mulher e a degolaram. Seguiram matando quem encontravam. Cercaram a aldeia, ficando escondidos em todos os caminhos.

No inicio da tarde, imitaram sons de animais, de onça. As pessoas da aldeia ouviam e comentavam. No meio da noite, os sons vindos da casa ${ }^{156}$ cessaram e os atacantes começaram a matar. Morreram muitas pessoas ${ }^{157}$, apenas três sobraram: Banubanu e seus dois sobrinhos. Eles começaram a contra-atacar os agressores, até os dois sobrinhos serem mortos.

\footnotetext{
${ }^{154}$ Os únicos personagens sempre nomeados são Banubanu, os Zumahideni e os Diideni.

${ }^{155}$ Uma das versões estipula que eram 50 guerreiros com 30 flechas cada um.

${ }^{156}$ Algumas versões fazem questão de salientar que nesse tempo viviam em apenas uma grande casa, mas a última aldeia é sempre composta por mais de uma casa. Outras colocam a existência de diferentes casas nas aldeias. A narrativa estaria, assim, gravitando num tempo passado não muito distante, situado para além da memória genealógica (já que os protagonistas não se ligam ao presente), mas num período em que as habitações já estavam se transformando no modelo atual. Até onde sabemos, nenhuma das pessoas ainda vivas teria vivido nas grandes casas redondas de antigamente.

${ }^{157}$ Especificado 200 em um das versões.
} 
Os zumahideni ${ }^{158}$ escutaram que estava tendo uma guerra e alguns deles se armaram para participar dela. Começaram a lutar com o pessoal do Kuimakhuvi e foram todos mortos, entre eles estava o filho do chefe Zumahideni.

Zumahideni pensou em vingar a morte do filho. Ele pegou suas armas, vestiu sua armadura ${ }^{159}$ e foi para a batalha. Ele tinha uma armadura impenetrável, acertavam flechas mas não furavam o corpo dele. Ele matou muitos do pessoal do Kuimakhuvi ${ }^{160}$ que fugiram levando a irmã de Banubanu que foi morta no meio do caminho.

Banubanu juntou muitas pontas de flecha e flechas quebradas e correu atrás do pessoal do Kuimakhuvi. Ele corria contornando o caminho, aparecia e matava um, corria para longe denovo. Foi matando alguns até que o pessoal do Kuimakhuvi pegou as canoas e atravessou o rio.

Banubanu atravessou o rio a nado, só com a cabeça fora da água. As pessoas viram e pensaram que era uma onça ${ }^{161}$, mas depois se convenceram que era ele mesmo.

O pessoal do Kuimakhuvi acendeu muitas fogueiras e ficaram no meio cantando e festejando. Banubanu ficou olhando, mas não conseguia encontrar o chefe. Ele foi afastando os fogos com o pé e se aproximando, até ficar ao alcance de uma flechada. Atirou e matou o chefe.

Banubanu desceu até o porto, pegou uma canoa e subiu o igarapé, pensando em ir morar com seus sogros ${ }^{162}$. Foi até chegar na aldeia dos diimadideni, que eram muito valentes. Após as conversas iniciais ele recebeu duas mulheres como esposas.

O pessoal do Kuimakhuvi foi atrás de Banubanu. Foram parando em todos os portos do igarapé até chegarem no da aldeia dos diimadideni. Chegaram perto e uma pessoa subiu em uma árvore grande para descobrir onde estava

\footnotetext{
${ }^{158}$ Nome de um coletivo que é chefiado por um homem homônimo, o Zumahideni.

${ }^{159}$ Em deni: eteru kharade, que numa tradução literal seria pele/couro duro.

${ }^{160}$ Em uma das versões, os zumahideni matam também os parentes de Banubanu.

${ }^{161}$ Bani zavirivi, o nome antigo da onça animal.

${ }^{162}$ Kukudeni, que seria o conjunto dos sogros masculinos, ou os afins de G+1 cujas filhas são desposáveis.
} 
morando Banubanu. De noite foram e mataram ele. Os diimadideni descobriram o ataque e mataram todo o pessoal do Kuimakhuvi.

Este condensado dos relatos acerca de Banubanu é representativo do período pós-regurgitação da humanidade atual. Embora tenhamos suprimido todos os diálogos, os personagens e coletivos compartilham uma mesma língua, todos falavam deni e estão divididos em aldeias e coletivos diferentes. Apesar dessa identificação com o presente, trata-se de um tempo de guerra de todos contra todos, no qual não há realmente aliados. Os zumahideni não se engajam no conflito para salvar ou vingar os parentes de Banubanu, eles apenas tomam conhecimento de um conflito em curso e resolvem tomar parte dele. Por sua vez, os diimadideni não vingam a morte de Banubanu, eles simplesmente exterminam o grupo de pessoas que estava atacando sua aldeia.

A narrativa não tem propriamente um início, pressupondo eventos anteriores. Makuturu vivia na aldeia do marido, algo que, se ocorrido nos dias atuais, em que o homem mora junto aos parentes da mulher, geraria comentários indicando que Kuimakhuvi roubou a esposa. Ele, de início, já é apontado como matador, tendo muito provavelmente raptado Makuturu de forma violenta anteriormente, não existindo referência a uma troca ou mesmo à existência de filhos. Ao questionar sobre a irmã que havia sido alvo de predação, isto resultou na deflagração do conflito que só terminou quando ambas as aldeias foram exterminadas.

Apenas dois coletivos aparecem nomeados nessa narrativa, os zumahideni e os diimadideni que são os únicos que sobrevivem aos eventos. A nomenclatura segue o mesmo padrão utilizado para os coletivos na atualidade, o nome de algum animal ou planta acrescido da terminação_deni, neste caso: zumahi (onça) e dii ${ }^{163}$ (vespa) ${ }^{164}$. Embora tenham sobrevivido ao ataque, não há, atualmente, moradores das aldeias do Cuniuá que se colocam como descendentes de membros desses dois grupos. Isto não é trivial, pois todos os conflitos ocorridos entre coletivos ainda existentes, isto é, com os

\footnotetext{
163 Algumas versões desses eventos apontam que são os diideni que recebem Banubanu. Preferimos utilizar a forma diimadideni (que se decompõem em dii + madi + deni) porque ela indica outra maneira de estabelecer coletivos (madi).

${ }^{164}$ Dii (uma espécie de vespa muito agressiva) e zumahi (onça) são animais que atacam sem serem provocados, fazendo parte das zamahira (coisas ruins).
} 
quais se estabelece uma relação de continuidade entre o passado de guerra e o presente, foram e estão sendo eliminados da memória ${ }^{165}$.

Descrições sobre como eram os coletivos humanos nesta época surgem em contraponto ao momento atual, mas nos enunciados são listados aqueles que existem atualmente e não os que participam da memória dos conflitos. Nesse contexto de guerras inter-aldeãs, dos quais não participam, os subgrupos, como costumam ser chamados pela literatura, que existem atualmente são caracterizados como endogâmicos, localizados e concentrados. Isto é, claramente, uma visão ideal de um passado em que só se vivia entre parentes, reforçado pela identidade de grupo e pela coresidência. Casamentos com não parentes, não co-residentes e de diferentes coletivos resultam sempre em conflitos, como é explicitado nos eventos que levaram à morte de Banubanu. Os Deni apontam que os coletivos atuais eram, antigamente de determinada forma, enquanto suas narrativas apontam o que houve com aqueles que não seguiam o modelo ideal de endogamia, guerra e extermínio.

Segundo afirmam os Deni, em dado momento de sua história, houve um encontro de diferentes aldeias que falavam a mesma língua. Pelos relatos de alguns: um grande chefe que estava no local disse que eram todos Deni, que todos falavam a mesma língua e, portanto, não deveriam guerrear entre si. Foi fundada, então, uma grande aldeia, na qual todos viviam juntos, mas, depois, as pessoas misturadas se dispersaram novamente. A partir desses momentos, as aldeias passaram a ser compostas por pessoas diferentes, que pertenceriam a coletivos que não teriam quaisquer características de um grupo coeso, estando disperso entre diferentes aldeias. O processo de mistura seria gradual e irreversível, não havendo cisões que levam as identidades de grupo em consideração.

Estamos realizando uma grande simplificação a partir dos relatos que obtivemos. A variação é muito grande entre eles: os mais novos tendem a apontar a mistura como tendo ocorrido no alto Cuniuá, enquanto alguns dos mais velhos afirmam que ela já existia no Mamoriá, e outros falam de sucessivas misturas. Koop \& Lingenfelter (1985) estabelecem até uma cronologia para as fundações de grandes aldeias formadas a partir de diferentes grupos. Entre 1930 e 1955, teria havido uma reunião na região das

\footnotetext{
${ }^{165}$ Após meses de convivência, foi possível obter informações sobre alguns conflitos que envolveram os coletivos ainda existentes. Foram, contudo, listagens do tipo $\mathrm{X}$ fez guerra com $\mathrm{Y}, \mathrm{Z}$ com W, sem nenhuma descrição dos eventos ou das pessoas envolvidas.
} 
cabeceiras do rio Aruá, afluente do alto rio Cuniuá, motivada por uma epidemia de sarampo. Essa reunião, sobre a qual obtivemos informações durante a pesquisa, não é, contudo, aquela que teria resultado na reunião de diferentes coletivos, situada anteriormente no tempo.

O que os Deni estabelecem para além das variações é que, após o período de guerras endo-linguísticas, a noção de que eles são um mesmo tipo de gente, cujo índice é a identidade linguística, prevalece. Mostramos no capítulo anterior como a relação entre língua e separação de tipos humanos está colocada desde o surgimento da humanidade atual. Quando esta relação é explicitada, isto é, quando ela surge no discurso de um chefe, é como se a categoria de parentes (uvibuva) sofresse uma expansão, passando a abarcar todos os Deni, isto é, todos que falava a mesma língua. Como já disseram Koop \& Lingenfelter, "os Deni constituem uma tribo unicamente pelo fato de possuírem uma língua em comum.” (1983: 1), mas isto parece ser válido tanto para os próprios indígenas quanto para os órgãos públicos e ONGs que atuam entre eles.

Gordon, em suas considerações a respeito das populações falantes de línguas da família arawá, a partir do caso Jamamadi, questiona que "os Jamamadi (e possivelmente os outros Arawá) não constituem algo como uma 'tribo' em termos linguísticos" (2006: 52). Respondendo à questão posta pelo autor, os Deni de fato se consideram um "povo", como dizem em português no contexto das relações interétnicas, quando falam o "povo Deni”, cuja identidade existe em função da língua comum, "independente da divisão em subgrupos" (2006: 52). Segundo as afirmações, a homogeneidade linguística é a única coisa relevante na ideia Deni de pertencimento a um macro-conjunto, de que são todos parentes frente aos Outros. Isso é evidente a partir do contato que os Deni estabeleceram com os Kulina e que não resultou na fusão da identidade de ambos, pois, segundo afirmam, estes últimos falam uma língua quase igual ${ }^{166}$, mas não a mesma que os Deni, logo fazem parte dos Outros ${ }^{167}$.

\footnotetext{
${ }^{166}$ Essa afirmação é dos próprios Deni, de que os coletivos foram tendo encontros que levaram à constituição dos Deni. Um desses encontrou foi com os Kulina, mas as diferenças linguísticas fizeram com que eles mantivessem identidades separadas. Na percepção Deni, a relação entre sua língua e a kulina é a mesma que existe entre o português e o espanhol. (deni:kulina::português:espanhol).

${ }^{167}$ No Xeruã, há algumas famílias Kulina vivendo em aldeias de predomínio Deni e vice-versa, sendo comumente frisada a identidade Kulina quando mencionam essas pessoas. A divisão interna aos Deni, por sua vez, raras vezes é listada gratuitamente.
} 
Durante nossa pesquisa, um senhor, morador da Cidadezinha, apontou que um dos missionários encontrou, em anos recentes, alguns Deni que habitavam na região do Pauini, fora da TI Deni e com os quais os Deni não teriam contato. A afirmação do missionário, de que eles falavam a mesma língua, levou a uma identificação dessas pessoas como sendo Deni, pois, no enunciado, eles eram categorizados como uvibuva e não como "parente" (em português), termo que utilizam para outras populações indígenas. Mesmo que nunca tenham sido vistos pelos Deni, essa população que, provavelmente, fala uma das línguas Jamamadi próximas ao Deni, era tomada como sendo parte dos Deni, ao ponto de especularem sobre seu subgrupo.

Se a auto-identificação dos Deni como um povo era menos evidente nos anos em que Gordon Koop conviveu com eles, após o processo de demarcação da TI Deni, a existência de aparelhos de radiofonia, campeonatos regulares de futebol e orelhões, e a participação no movimento indígena, essa identidade foi reforçada. O que se reforça com o aumento da comunicação intra-Deni e inter-aldeã é a relação que eles, enquanto um "Nós", mantêm com os Outros. O mesmo poderia ser dito sobre a participação no movimento indígena que figura como um momento em que se percebe e se evidencia a relação com os não indígenas, surgindo e reforçando a ideia de um "Nós" indígena.

Por exemplo, a precarização dos cuidados à saúde nos anos recentes era vista, pelos Deni, como algo que atinge todos os indígenas, fruto de um problema na relação entre a FUNASA, como um termo, e os indígenas, como outro. As falas que uma liderança Deni fez nas assembleias eram vistas como sendo dirigidas exclusivamente à FUNASA e não aos membros da organização indígenas e não eram diferentes de outras conversas particulares tidas com agentes da FUNASA, era apenas um momento em que os indígenas agiam como um conjunto, o que tornou efetiva sua reivindicação, levando a uma melhora (ao menos para os Deni) nos cuidados da saúde por parte do Estado. Neste momento, o emissor, embora fosse Deni, apresentava uma mensagem que tinha como origem os indígenas e não propriamente os Deni, ou a própria liderança.

O questionamento de Gordon sobre as auto-identificações étnicas baseadas na língua, para além das identidades de "subgrupo", parte do caso Jamamadi, que é um caso complicado por si mesmo. Como quase todos que já escreveram sobre a região salientaram, Jamamadi (zamamadi) quer dizer gente da mata, ou seja, é, em si, um termo que abarcaria todas as gentes que não moravam na beira dos rios: Deni, Kulina, Jarawara, Banawá, etc.. De fato, o termo continua, ainda hoje, classificando populações 
de terra firme que falam línguas muito diferentes. Como aponta Dienst (2008) há populações nomeadas como Jamamadi que falam uma língua semelhante ao kulina e deni, participando de uma mesma subdivisão da família linguística, e outras que possuem um idioma mais próximo ao banawá e jarawara, sendo parte de outra divisão.

As afirmações de Rangel, no que tange às diferenças linguísticas entre os Jamamadi das proximidades de Boca do Acre, cujas línguas seriam mais semelhante ao deni e kulina, não são muito claras. Um

"informante explicou que existia um grande número de grupos que diferenciavam sua linguagem através do sotaque e da entonação: uns aspiravam o 's', outros não, alguns falavam rápido, num canto fino, outros falam grosso, num cantado lento e as diferenças, assim expressas, provocavam risos e eram até motivo de chacotas" (1994: 81-82).

Em outro momento, contudo, ela apresenta uma pequena lista do vocabulário (: 94) de dois subgrupos Jamamadi, os sivakoedeni e os tanodeni. Nela é possível perceber uma grande quantidade de termos não cognatos, cujas diferenças iriam muito além de simples variações de pronúncia. Sem podermos saber se é representativa, sua lista de 24 termos apresenta 7 (29\%) não cognatos ${ }^{168}$. Se os próprios indígenas reconhecem não se tratar de uma mesma língua e os dados linguísticos apresentados pela autora nos fazem crer que talvez não o seria nem mesmo para os linguistas, é de se esperar que não faça sentido para eles o estabelecimento de uma identidade entre os subgrupos sivakodeni e tanodeni. Eles falam de forma diferente, logo não possuem uma base comum sobre a qual se assentaria um agrupamento maior.

A questão da relação entre a língua e o recorte nativo de uma unidade já foi mostrada para o caso Deni. Entre aqueles conhecidos por Jamamadi, qualquer identidade informada pela língua seria uma impossibilidade prática, mas nada impediria o estabelecimento de agrupamentos para além dos subgrupos entre aqueles de fala comum. Maizza aponta, em relação aos Jarawara, que, embora não haja "referência direta aos subgrupos [...] eles afirmam que são a mistura de dois povos, Jarawara e Wayafi (ou Wa-yafi), que falavam a mesma língua" (grifo nosso 2012:37).

\footnotetext{
${ }^{168}$ Entre estes estão: gente (português), madiha (sivakoedeni), ioasere (tanodeni); avó (p), ini (s), okkasi $(\mathrm{t})$; macaxeira $(\mathrm{p})$, nomihari $(\mathrm{s}), \operatorname{himeka}(\mathrm{t})$; caiçuma $(\mathrm{p})$, zamapani $(\mathrm{s})$, kuzahari $(\mathrm{t})$.
} 
Azevedo aponta algo semelhante entre os Suruwahá, argumentando que, entre outras coisas, “o que torna um grupo de pessoas um 'povo', para eles, é o fato de [...] falarem uma mesma língua" (2012: 83). Os Suruwahá se constituíram enquanto um povo a partir do momento em que as pessoas dos grupos que se desconheciam “ 'perceberam repentinamente' que não eram as únicas a falar uma língua bonita" (Azevedo 2012: 112). A partir dessa tomada de consciência, passaram a "visitar-se, tentaram fortalecer suas novas relações através do estabelecimento de alianças matrimoniais em primeiro lugar, e da adoção de crianças provenientes dos respectivos outros grupos" (: 119).

Devemos ter em mente que agrupamentos de tipo étnico são sempre complicados. Não seria possível afirmar que há uma sociedade Deni dividida em grupos componentes, tal como seria o modelo de sociedade preconizado por Durkheim (2008 [1893]). É evidente, contudo, que eles próprios criaram um mundo (Strathern 2009[1988]) em que uma totalidade Deni existe para além dos coletivos menores. Por um lado, os Deni se consideram como compostos por diferentes tipos de pessoas, o que é valorizado, já que proporcionou a paz intra-étnica, mas, por outro lado, eles sempre reafirmar sua pureza, são o resultado de uma fusão que contou exclusivamente com falantes do deni ${ }^{169}$. O que se marca são os limites dos parentes (uvibuva), entre os quais, enquanto pessoas e não enquanto coletivos, deveria imperar o modo relacional da dádiva, ocorrendo o modo da troca ${ }^{170}$, apenas, entre afins efetivos, já que toda forma de predação é condenada, embora ocorra.

Mesmo que não seja amplamente tematizada, sendo praticamente impossível encontrar objetivações das diferenças entre os subgrupos Deni ${ }^{171}$, há uma noção geral de que as pessoas pertencentes a cada um deles não eram semelhantes. Na coletânea do Xeruã, há um mito que apresenta a história dos Vahadeni (Povo Deni da Arara - Sass 2004: 48-49). Nele é tematizada a diferença de perspectiva existente entre o

\footnotetext{
${ }^{169}$ Eles se oporiam assim aos nativos do baixo Urubamba que, como aponta Gow (1991), afirmam que são de sangue misturado e é graças a isso vivem melhor que seus antepassados.

${ }^{170}$ Para a tematização da troca entre os Deni veja Florido (2013).

${ }^{171} \mathrm{Um}$ senhor, de aproximadamente 55 anos, listou algumas palavras que seu subgrupo falaria de forma diferente. Outro, com aproximadamente 30 anos, apontou as mesmas palavras como sendo da época do seu avô (de 75-85 anos), um homem vivo que já teria nascido em um contexto misturado. Faria mais sentido imaginar que se tratavam de termos presentes nos "relatos dos antigos" e que um situaria como sendo relatos dos seus próprios antigos, isto é, de seus ancestrais de subgrupo e o outro como sendo de seu avô. Há duas possibilidades: ou, de fato, os membros de diferentes subgrupos apresentavam diferenças linguísticas perceptíveis, ou a existência de diferenças linguísticas é colocada como fato necessário para existirem diferenças entre os subgrupos.
} 
protagonista e os Vahadeni: quando um vê o dia o outro vê a noite; um caça antas que o outro vê como ratos; um sofre para carregar a caça abatida enquanto o outro a segura com apenas uma mão, etc. Infelizmente os Vahadeni são exterminados por "índios bravos", o que impede ocorra a fusão entre eles e os parentes do protagonista, apenas uma mulher, que havia casado com o protagonista, permanece viva e passa a habitar na aldeia deste.

Precisamos recorrer a um mito do Xeruã, pois, só conhecemos uma narrativa a respeito dessa temática no Cuniuá, mas ela não possui grande difusão, tendo sido, possivelmente, criada pelo chefe e xamã da aldeia Zunamete. Tivemos contato com os eventos que ela apresenta a partir de dois irmãos, um morador da aldeia Zunamete e o outro da Cidadezinha, que indicaram sua origem. A partir do que se observa na coletânea do Xeruã, é possível afirmar que, apesar de sua raridade nos discursos, este enunciado fez uso de noções difundidas no pensamento Deni. Trata-se de uma narrativa cujos protagonistas são membros de coletivos existentes nos dias de hoje e que não faz menção a qualquer conflito.

Antigamente $^{172}$ não tinha $a p u^{173}$, só tinha mudukusu ${ }^{174}$. Os tamakurideni e os minudeni achavam que eles eram apu, então derrubavam árvore bathu e sisiri para criar mundukusu. Eles andavam longe para derrubar 3-5 árvores, depois esperavam cinco meses e iam tirar apu. Estavam acabando com as árvores no mato.

Os havadeni chegaram à casa dos tamakurideni e minudeni e casaram com as mulheres deles. Eles convidaram o cunhado Havadeni para irem tirar apu. Andaram e passaram por muitos troncos velhos caídos, já estavam longe quando encontraram a árvore que tinha sido derrubada. Limparam em volta da árvore e começaram a cortar com o machado. Saiu muito mudukusu.

O Tamakuri e o Minudeni ficaram animados, dizendo que tinha muito ари. O Havadeni olhava e pensava que eles estavam enganados, que aquilo não era $a p u$, era outra coisa. Encheram um panaco pequeno e levaram para casa. $\mathrm{O}$

\footnotetext{
172 Marcação temporal nizamani: antigamente, muitos anos atrás, primeiro. Ela se situa no período anterior à fusão, evento ocorrido antes da memória genealógica, no tempo dos imabute.

${ }^{173}$ Uma larva de besouro comestível que é cultivada pelos Deni em troncos de buriti ou de patauá que são derrubados e preparados para que surjam as larvas. É um alimento muito apreciado, tido como muito gorduroso (ukide).

${ }^{174}$ Uma espécie de larva não comestível.
} 
Havadeni entregou para a mulher, que assou e comeu sozinha. Ele se recusou a comer.

Três dias depois, o Havadeni foi até o mato e derrubou cinco árvores de patauá e cinco de buriti. Passados quase três meses, ele chamou os cunhados para irem ao mato. Encontraram, primeiro, os troncos de buriti e, como tinha muito apu putahari $^{175}$, encheram um panaco grande. Foram, depois, nos troncos de patauá, nos quais tinha muito apu birihari.

Os minudeni e os tamakurideni provaram o apu e acharam muito gostoso. Deixaram a cultura ${ }^{176}$ deles e pegaram a dos havadeni. Agora todos comem apu mesmo.

Essa narrativa é particularmente interessante, pois está situada em um passado muito recuado no tempo, mas seus protagonistas se ligam às pessoas vivas. Entre os vivos existem havadeni, tamakurideni e minudeni, ou seja, se estabelece uma relação de continuidade entre estes eventos e os dias atuais. A fusão aparece claramente, de início os protagonistas são diferentes, já que não veem as coisas da mesma forma, ou melhor, eles veem as mesmas formas (os $a p u$ ) sobre substratos diferentes ( $а р u$ e mudukusu), ou seja, suas perspectivas são diferentes, mas, após morarem, juntos eles passam a compartilhar a mesma.

Como já apontamos anteriormente, a fusão carrega em si um aspecto positivo. Neste caso, é explicitado que, ao passar a compor a comunidade aldeã com os havadeni, os tamakurideni e os minudeni, os dois últimos passam a se valer de um alimento propriamente humano, já que antes, tomavam por comida saborosa algo que não seria tão bom. O próprio narrador comenta sobre a história que o mudukusu, que não é comido por ninguém atualmente, também deveria ser comestível, mas seu gosto devia ser pior que os $a p u$, tendo pouca gordura.

De maneira geral, os discursos que envolvem relações positivas entre os subgrupos estabelecem um passado que se liga diretamente ao presente e que diferem das narrativas sobre o passado de guerra intralinguística, com o qual os vivos não

\footnotetext{
${ }^{175}$ Há dois tipos de apu: apu putahari (grande) e apu birihari (pequeno).

${ }^{176} \mathrm{O}$ termo cultura foi utilizado pelo próprio narrador quando ajudou a traduzir a história. Os Deni geralmente aplicam o termo cultura para mencionar um conjunto de saberes e valores que tipos humanos possuem e podem trocar, perder, adquirir. Há, assim, a cultura dos Deni, a cultura do pajé, a cultura dos brancos, talvez a cultura dos animais, mas este último uso não era algo comumente dito. A forma como empregam o termo cultura é semelhante àquela utilizada pelos teóricos da aculturação (Ribeiro 1993).
} 
estabelecem uma relação direta. A continuidade é enfatizada com o momento em que a paz está estabelecida, são os ancestrais que viviam entre si da forma apropriada para com os parentes; a descontinuidade é estabelecida com o tempo da guerra, ninguém querendo situar a si, ou aos parentes (os Deni), na descendência daqueles que matavam. Os discursos da guerra são gerados de forma a indicar que os protagonistas se dividem como atualmente, ou melhor, como se dividiam os ancestrais das pessoas ainda vivas, sem se confundir com as divisões existentes na atualidade.

No passado de paz intra-Deni, em que a dádiva é o modo relacional apropriado internamente, o que antes eram diferenças guerreiras tornaram-se relações de afinidade, isto é, parte dos Outros deixou de ser situada em meio aos inimigos e passou a representar aqueles com quem se estabelece a troca. Não são, contudo, os coletivos que mantinham agressões entre si que passam a trocar. Nada impediria que disséssemos que a afinidade pura, isto é, que não passa pela realização de alianças matrimoniais, foi sendo despotencializada (Viveiros de Castro 2002), mas isto não é assim formulado pelos próprios Deni.

Inicialmente, é uma expansão da categoria de parentes (uvibuva), que passou a incluir alguns que, até aquele momento, eram não parentes e não afins (não se casava com outros subgrupos ${ }^{177}$ ), que permitiu cessarem as guerras e serem estabelecidas, posteriormente, as alianças matrimoniais. De todas as narrativas com que tivemos contato, nenhuma tematiza a transformação de inimigos em afins, mas muitas tratam do movimento inverso, em que afins efetivos, quase que invariavelmente cunhados, tornam-se oponentes em um ataque guerreiro. Na política cósmica, ao que parece, a tendência é que as relações se deteriorem para os conflitos.

Nos dias de hoje, o termo para cunhado (abuni) é utilizado como vocativo para as outras populações indígenas e não indígenas, mas não podemos afirmar que o uso seja anterior ao surgimento de relações matrimoniais entre eles. Uma das moradoras mais velhas da aldeia Cidadezinha é fruto do casamento, segundo afirmam os próprios Deni, de um branco e uma moça Deni, ocorrido ao menos 60 anos atrás. O casamento foi desfeito com a retomada da moça, mas tratava-se, sim, de uma relação de afinidade

\footnotetext{
177 Muitas narrativas mencionam os casamentos entre aldeias diferentes, porém os discursos sobre o tempo das separações dos subgrupos sempre mencionam a ausência de aliança matrimonial entre as aldeias. Podemos presumir então que estes casamentos eram sempre resultado da abdução de mulheres de outra aldeia.
} 
efetiva, ou seja, o vínculo autorizaria a utilização do termo cunhado no tratamento com este branco e por associação com todos os outros com quem se tinha contato na época.

O próprio termo para cunhado utilizado atualmente (abuni) não é o mesmo de antigamente (ukheve). Se ukheve era o termo para inimigo, isto não aparece no presente, embora algumas traduções associem o termo com respeito e perigo, outras seguem a linha oposta, colocando que as pessoas nesta relação eram amigas, companheiras. Nos dias de hoje, abuni parece excluir o conflito, sua utilização podendo estar associada com a tentativa de neutralizar o potencial agressor dos kariva.

De qualquer forma, há uma grande diferença de disposições entre afinidade e guerra. Tomemos os kariva, sendo eles situados como afins, existe a possibilidade de que, no limite, venham a se tornar parentes e, com o convívio, estabelecer outros vínculos de parentesco. Isso de fato ocorre, não se tratando apenas de casos em que, após certo tempo de co-residência, o kariva passe a ter pais, mães, irmãos, etc. e não apenas cunhados, mas da sua transformação propriamente em madiha. Este é o caso de um dos missionários que não fortuitamente domina a língua deni do ponto de vista dos próprios indígenas. No caso dos inimigos, isto não parece se colocar, eles nunca, nas narrativas, são transformados em parentes, em humanos de forma apropriada.

A guerra Deni parece ser uma guerra de aniquilação, que, talvez, tenha por objetivo negar a vingança latente, não visa alimentar uma espiral de vinganças, mas, sim, o seu cancelamento. Essa forma do conflito guerreiro é a mesma, tanto no tempo mítico da primeira humanidade, quanto no tempo histórico dos pais e avôs de pessoas ainda vivas. Como já indicamos, houve o estabelecimento inicial de uma paz intralinguística, mas os conflitos exolinguísticos continuaram a ocorrer, embora sua memória esteja sendo apagada (ou não é enunciada ao antropólogo). Os únicos conflitos deste tempo de que temos notícias detalhadas diz respeito à aniquilação dos abadeni. Tratam-se de dois episódios que, no limite, poderiam ser o mesmo, pois seus protagonistas são irmãos e provavelmente teriam participado dos mesmos ataques, porém suas descrições só se assemelham no início.

É impossível recuperar a identidade dos Abadeni (aba - peixe), os dois narradores oscilaram entre identificá-los aos Katukina ou aos Paumari. Na região do Purus, não é incomum encontrar referências a "gente peixe": os Suruwahá mencionam os abamadi ('gente dos peixes' - Aparício Suarez 2013), os Jamamadi descritos por 
Rangel (1994) falam dos abadeni. Possivelmente tenhamos aqui o mesmo fenômeno que fez surgirem os "Zamamadi” (ou Jamamadi como foi cristalizado), o contato com as populações da terra firme, mediado pelas populações localizadas nas margens do Purus, fez com que a categoria nativa utilizada para as populações não ribeirinhas fosse aplicada indiferentemente a uma grande quantidade de grupos distintos.

A gente-peixe ${ }^{178}$, por sua vez, provavelmente corresponde a forma como as populações de terra firme falavam sobre aquelas que habitavam no rio, o termo recortaria, desta forma, populações muito diferentes ${ }^{179}$, cujo ponto em comum seria não habitar na região de várzea. Os próprios Deni apontam que eles eram chamados abadeni porque moravam nas margens do rio Aruá, no alto Cuniuá, e não faziam roçado, numa época em que os Deni ainda se mantinham em terra firme, instalando suas aldeias nos altos dos igarapés. Se a frente de expansão tivesse penetrado a região do Purus pelo interior, e não pelos rios, possivelmente os Abamadi teriam se fixado como etnônimo de alguma (ou muitas) população indígena.

Não faria sentido nos atermos aos detalhes destes conflitos. Em resumo, em um deles, cujo narrador não adotou uma postura condenatória do seu bisavô que foi à guerra, os Abadeni foram até um roçado antigo para roubar as frutas e os vegetais que ainda existiam nele e, após comerem, permaneceram no roçado. Quando o dono da plantação foi buscar algumas frutas, o cachorro dos Abadeni sentiu o cheiro dele, latiu e correu em sua direção. Os abadeni gritaram "Madi!" (gente). O homem correu em direção aos Abadeni e flechou um, depois outro. A esposa do Abadeni morto atacou o dono do roçado, mas utilizou um terçado que não o feriu. Ela foi morta na sequência pelo irmão do agredido. Os irmãos foram matando os Abadeni que conseguiram, até que estes atravessaram o rio nadando. Os Deni pegaram duas crianças dos Abadeni, mas não queriam criar, então as deixaram na praia do rio.

O outro relato, que pode ser um evento independente, ou tratar do mesmo incidente, ou mesmo ser a sua continuação, parte, também, do roubo de plantas cultivadas por parte dos Abadeni. O narrador assumiu uma atitude extremante condenatória em relação ao pai que teria participado desse ataque, atribuindo a ele

\footnotetext{
${ }^{178}$ Para os Kulina, existiriam também os aba-madiha. Não podemos comentar muito sobre eles, já que as informações são escassas. Segundo os dados de Viveiros de Castro (1978) eles se localizariam no rio Envira, no rio Juruá e na aldeia San Bernardo, ou seja, estão associados a dois rios e não a igarapés.

179 Essa interpretação dos abadeni surgiu em meio a uma conversa com Ingrid Daiane dos Santos, mestranda do programa de antropologia social da Universidade Federal do Amazonas.
} 
características negativas, como a valentia, gosto pela guerra e, inclusive, atos de canibalismo $^{180}$. O dono do roçado, irmão do agressor anterior, viu que tinham roubado suas plantas e seguiu o rastro dos ladrões até a aldeia dos Abadeni. Ele voltou para sua casa e conversou com seu pessoal. Eles se armaram e saíram. À noite, chegaram à aldeia e a cercaram, imitando sons de animais para ver se alguém respondia. De madrugada, começaram um ataque que durou até quase de manhã, durante o qual foram mortos todos os Abadeni.

Independente de serem dois eventos distintos, ou um mesmo com duas versões muito diferentes, o ataque visa o extermínio dos Abadeni. A motivação inicial é a predação, por parte dos Abadeni, que acaba resultando no conflito. A violência, contudo, não corresponde a uma contra predação, ela procura encerrar uma relação pela subtração de um dos termos. No relato em que duas crianças ficaram com os Deni, ao invés de levarem-nas para a sua aldeia, isto é, acionarem o modo predação durante a guerra, eles as abandonaram na praia, onde provavelmente terminou o conflito. A violência é, puramente, a resposta ao roubo, não trazendo nenhum valor associado, além de restituir aos Deni a perspectiva de predador e não de presa na relação com os Abadeni.

Este é o último conflito de grandes proporções em que os Deni se envolveram e, o único, em que a guerra se situa dentro do limite da memória genealógica, isto é, que tem como participantes pais e avôs de alguns velhos ainda vivos. Após esse episódio, não cessa a disposição para a guerra com os outros, pois esta continuaria até o estabelecimento do convívio com os brancos, o que teria levado a pacificação total. Os motivos que levaram ao abandono das disposições guerreiras não parecem se colocar como uma questão aos Deni, que se importam em pontuar, apenas, os momentos em que ocorreu.

Os Deni afirmam que nunca mataram um branco ${ }^{181}$, mas sua aparição no horizonte acaba por torná-los o limite máximo para o parentesco, a partir do qual o

\footnotetext{
${ }^{180} \mathrm{O}$ canibalismo é um tema sem muita relevância nas narrativas sobre os conflitos, dificilmente estando presente. Ele aparece na história do marido canibal, que uma pessoa associou com o diabo; numa narrativa sobre o avô que comia os netos; e no destino post mortem dos que têm comportamentos inapropriados. Voltaremos a este ponto no próximo capítulo.

${ }^{181}$ Até onde sabemos a única exceção seria um xamã de antigamente, que invadia os barcos dos brancos, matava a tripulação, levava todas as mercadorias e afundava os barcos. Ele era um personagem participante de muitas narrativas que apresentam suas características negativas, era um grande matador, ninguém conseguia mata-lo. É possível, tal como afirmam para os xamãs que atualmente matam muitas pessoas, que ele não fosse mais madiha, tendo perdido sua condição propriamente humana.
} 
"Nós", com quem não se faz guerra, pode se expandir até o seu encontro. A presença dos kariva permite o surgimento da noção de um "nós indígenas". Esta identidade indígena, enquanto um conjunto de parentes, entre os quais não deveria haver conflitos, parece só se consolidar plenamente no contexto do movimento indígena.

O próprio abandono da violência, na relação entre humanos, se processa no tempo, podendo ser marcado seu fim com a última morte ${ }^{182}$ de um xamã do Cuniuá, ocorrida no Xeruã por volta de $1966^{183}$. Este assassinato vitimou um chefe e xamã reputado como muito poderoso. Ele morava numa aldeia localizada no igarapé Maravilha, no alto Cuniuá, e havia ido até o Xeruã para trocar couro com um patrão daquela região. Este xamã havia causado muitas epidemias e mortes nas aldeias do Xeruã, então, as pessoas combinaram de matá-lo, o que envolveu bebidas alcóolicas, tiros de espingarda e o esquartejamento do seu corpo. Após essa morte, o tempo teve uma tempestade, o dia escureceu, houve raios e muito vento, que só foram dispersos quando outro xamã levou seu espírito embora.

Quando as notícias sobre seu assassinato chegaram à sua aldeia, as pessoas ficaram desesperadas, passaram a mudar constantemente o lugar da aldeia, temendo novos ataques, até que abandonaram a vida em terra firme e foram se estabelecer junto ao Adriano Lopes, fundando a aldeia Marrecão. Dois irmãos, que já moravam entre os brancos antes desses eventos, disseram que pensaram em vingar esta morte, mas foram demovidos por Chico Severo. A partir desse momento, há uma abdicação da violência e da vingança, e nem mesmo os xamãs são alvos de ataques guerreiros. Os conflitos entre humanos passaram, então, a se processar por meio das agressões xamânicas.

\section{3 - Os coletivos arawá}

Até esse momento, estivemos falando de subgrupos ou citando alguns nomes de coletivos sem nenhuma caracterização apropriada dos mesmos. As únicas informações que apresentamos acima dizem respeito à idealização de sua forma passada, visto que os Deni afirmam que, antes, estes subgrupos seriam unidades endogâmicas e localizadas, isto é, todos morariam em uma mesma aldeia e casariam entre si. Nesse tempo, não haveria uma totalidade Deni demarcada, da qual os grupos seriam partes componentes, a

\footnotetext{
182 Com exceção de uma morte acidental durante uma briga entre os Deni, após este assassinato somente os xamãs continuam a matar pessoas.

${ }^{183}$ Essa data deve-se a Koop \& Lingenfelter (1983).
} 
noção de que existe algo como "os Deni”, uma unidade, surgiu após a unificação e foi sua causa e consequência.

Muita literatura já foi escrita sobre os subgrupos nomeados das populações da família linguística arawá ${ }^{184}$, sendo um tema inescapável na região. No caso Deni, suas denominações são compostas por nome de animais ${ }^{185}$, $\operatorname{plantas}^{186}$, partes de $\operatorname{plantas}^{187}$, ou elementos da natureza, como igarapés ${ }^{188}$, acrescidos do sufixo_deni. Fornecer uma lista de nomes não nos parece interessante, já que não dispomos das informações que seriam relevantes para todos eles, como o local de origem ${ }^{189}$. Aqueles interessados podem consultar os dados de Chaves (2001), que apresenta uma lista informando a origem de alguns grupos, assim como a compilação de Rodrigues (2011) que apresenta nomes de subgrupos para diversas populações da região.

O pertencimento a um desses grupos, no caso Deni, ocorre através da descendência patrilinear ${ }^{190}$, uma pessoa fazendo parte do mesmo coletivo que seu pai. Isto está relacionado à teoria da concepção, segundo a qual, uma pessoa é formada pelo acumulo de sêmen (maza). A mãe possui uma espécie de fôrma (eheve taputu ${ }^{191}$ ) em que o sêmen é depositado, não contribuindo com nenhuma substância para o corpo da criança. Essa explicação é acionada quando se trata da questão da transmissão do subgrupo, mas, também, se reflete no parentesco, com meios-irmãos por parte de pai sendo mais próximos do que meios-irmãos por parte de mãe.

Apenas quando desconhecem (por exemplo, os filhos de pai kariva) ou não recordam (filhos de uniões com pessoas há muito falecidas e sem parentes vivos,

\footnotetext{
${ }^{184}$ Veja Koop \& Lingenfelter (1983), Pollock (1985a), Lorrain (1994), Rangel (1994), Gordon (2006), Bonilla (2007), Jardim (2009), Rodrigues (2010, 2011), Azevedo (2012), Aparicio Suarez (2013).

${ }^{185}$ Por exemplo, tamakurideni, sendo tamakuri uma espécie de macaco.

${ }^{186}$ Por exemplo, havadeni, sendo hava uma espécie de palmeira, o patauá.

${ }^{187}$ Por exemplo, bukuredeni, sendo bukure o âmago da madeira.

${ }^{188}$ Por exemplo, upanavadeni, sendo upanava o nome de um igarapé.

${ }^{189}$ Para alguns dos subgrupos, os Deni não apresentam qualquer dificuldade em atribuir uma localização original, mas, para outros não há uma clareza quanto à origem geográfica.

190 Essa é a ideia que parece estar mais consolidada atualmente, mas alguns Deni, inicialmente, apontavam para uma descendência paralela. Nas raras vezes em que alguém apontou esse paralelismo em meio a outras pessoas, um debate surgia e, como resultado, eles se convenciam de que o pertencimento ao grupo ocorria por via patrilinear. A partir dos dados censitários de Chaves (2001) é possível perceber que há a presença de descendência paralela, algumas mulheres sendo consideradas como pertencentes ao mesmo subgrupo que suas mães e os homens que seus pais. Lorrain (1994) aponta descendência paralela para os Kulina.

${ }^{191}$ Pode ser que seja o útero, mas parece que a ideia seja de uma fôrma que irá moldar o sêmen. Não podemos falar muito sobre o termo eheve taputu, apenas que seria o taputu da criança (eheve). É interessante notar que as roupas são chamadas de tutaputu, e que, talvez, seja possível decompor em tu (possessivo - dele) taputu, ou seja, o taputu dele. Nesse sentido, a roupa seria o que dá uma forma ao corpo dos brancos, assim como o eheve taputu dá forma ao corpo do feto.
} 
possivelmente casamentos com indígenas não-Deni) o subgrupo do pai, é que os filhos recebem da mãe. Dado o princípio de pertencimento, todos os irmãos e meios-irmãos paternos fariam parte do mesmo grupo nomeado, com exceção dos casos irregulares, isto é, aqueles em que a paternidade não seria clara. Pessoas que compartilham uma mesma identidade deveriam, portanto, possuir um ancestral comum com o qual se ligam por linha agnática, por uma cadeia de vínculos de filiação paterna.

Em 2011, a pedido de uma das lideranças Deni, realizamos o levantamento populacional das seis aldeias Deni do rio Cuniuá, obtendo as (auto-)identificações aos subgrupos para a maior parte da população deste rio. Embora, entre os moradores de cada uma das aldeias, a lógica de pertencimento seja geralmente seguida, isto é, os filhos de um homem se identifiquem de forma semelhante, quando consideramos irmãos habitantes de localidades diferentes, há maior variação. Os dados que obtivemos mostram que muitos irmãos ou meios-irmãos por parte de pai não se classificam da mesma forma. Longe de ser um fenômeno novo, vemos que os dados censitários fornecidos por Chaves (2001) apresentam variações no mesmo sentido, havendo pessoas que não seriam do mesmo subgrupo que seus pais.

Dado que não há correspondência entre o modelo nativo de composição dos coletivos e o que é possível ser apreendido no nível empírico, seria importante nos atermos aos momentos em que os subgrupos surgem na vida cotidiana, mas não fomos capazes de perceber a sua operacionalização no cotidiano ou nos diálogos entre os próprios Deni, pois, todas as referências feitas a coletivos que seriam identidades surgiram no curso da investigação do antropólogo ${ }^{192}$. Durante o levantamento dos dados genealógicos, quase ninguém fornecia espontaneamente seu próprio subgrupo ou aqueles de seus pais e avós; alguns, contudo, o faziam prontamente, indicando as filiações de qualquer pessoa mencionada em seu discurso. Ao longo da investigação etnográfica, tornou-se evidente que não éramos os primeiros a inquirir sobre essas informações, ficando claro que, em ao menos quatro vezes anteriores, eles já haviam fornecido os mesmos dados: para Gordon Koop do SIL, para duas equipes do CIMI, e para o relatório de demarcação da FUNAI. Aqueles que forneciam os dados completos logo de inicio, provavelmente, já haviam sido informantes nessas pesquisas anteriores.

\footnotetext{
${ }^{192}$ Muito raramente, a identidade de subgrupo de alguém surgia como um elemento explicativo para algo. Por exemplo, um homem que havia casado de forma errada, isto é, com uma mulher com quem não deveria ter relações sexuais, afirmava que seu caso não traria consequências negativas para si, pois ela era de um subgrupo diferente do seu.
} 
De uma forma geral, o pertencimento a um ou outro dos subgrupos não é algo amplamente conhecido e alguém não saberá informar todas as afiliações dos moradores da sua própria aldeia. A identidade de subgrupo tem sido usada, atualmente, como sobrenome, quando os Deni tiras seus documentos: certidão de nascimento, RANI (registro administrativo de nascimento indígena - FUNAI). Um caso da aldeia Cidadezinha mostra que nem a identificação do próprio pai era algo amplamente conhecido. O AIS da aldeia Cidadezinha, quando precisou se registrar para ser contratado, por volta do ano 2000, num momento em que quase nenhum Deni possuía certidão de nascimento, identificou-se como Varashadeni; já seu pai, anos depois (2009), quando fez seu próprio registro assumiu a identidade de Meiveshedeni, o mesmo sendo feito pelos seus outros filhos. A explicação do AIS é que ele possuía muitos avôs paternos e isso fez com que ele optasse por um sobrenome diferente daquele que seu pai assumiu posteriormente ${ }^{193}$. O ponto importante parece ser que ele não sabia, a princípio, qual era a identificação de seu próprio pai, pois, provavelmente, isto era irrelevante na época em que os Deni não possuíam documentos.

Este caso não é o único, pois muitos discordam da identidade que lhes foi atribuída, ou da auto identificação de outras pessoas. Muitos upanavadeni dizem que, na realidade, são bukuredeni e que os upanavadeni não existem, mas, como eles moravam no igarapé de nome Upanava, as pessoas começaram a chamá-los assim e o nome foi erroneamente fixado ${ }^{194}$ sobre eles. O uso desse termo remonta pelo menos à década de 1970, quando o nome foi fixado pela primeira vez por Gordon Koop. O Deni mais velho com quem conversamos apontou que ele é kamadeni ${ }^{195}$, embora outros afirmem que ele é upanavadeni.

Referências a essa discordância, entre autoimagem e a visão de outros, são abundantes. Muitos que se assumem como bukuredeni seriam, para outros, tamakurideni e/ou varashadeni. Um homem adulto (com aproximadamente 35 anos) chegou ao ponto de afirmar que os bukuredeni não existiam até recentemente, quando o

\footnotetext{
${ }^{193} \mathrm{E}$ os dados de Chaves (2001) colocam esse pai (no. 53 na lista da Cidadezinha fornecida pelo autor) e seus filhos homens (no. 55 e no. 60) em outro subgrupo, os Tamakurideni, já suas filhas (no. 64 e no.86) são colocadas no subgrupo da mãe (no. 54).

${ }^{194}$ Koop \& Lingenfelter (1983) são taxativos ao afirmar que os "Upanavadeni são os Deni do rio Upanava (Mamoriá)" (:1). Os dados que eles fornecem, contudo, apontam vários subgrupos como procedentes de regiões circunscritas do Mamoriá, mas somente os Upanava teriam o nome do rio. Os Deni, hoje, não associam o Upanava com o rio Mamoriá, mas com um igarapé.

${ }^{195}$ Kamadeni é a autodenominação de uma população indígena que habita no rio Mamoriá. Tanto eles quanto os próprios Deni parecem reconhecer que possuem relações históricas.
} 
xamã mais velho da região afirmou que ele próprio e muitas outras pessoas eram bukuredeni $^{196}$, o que levou ao abandono das outras identidades e à incorporação desta. Essas discordâncias podem ser tomadas como indicativos de que, de fato, os subgrupos não existem, seja enquanto subdivisões da Sociedade Deni, sejam como coletivos delimitados, isto é, não são grupos sociais no sentido que nós atribuímos ao termo (Wagner 1974).

Para entender o que são os "subgrupos" para os Deni, seria melhor considerar outros contextos etnográficos da região. As informações que possuímos, obtidas durante a pesquisa de campo, dizem respeito à visão Deni em determinado momento histórico particular; de forma semelhante, cada etnografia das populações do interflúvio Juruá Purus foi cristalizando certas configurações destas unidades. As descrições foram apresentando supostas características destes grupos, num modelo ideal que sempre se apontava como não correspondendo ao que se observava no plano empírico. Diferentes autores que trataram esses subgrupos apontavam que eles poderiam ter perdido sua função, ou da "possibilidade de ser uma instituição em decadência" (Viveiros de Castro 1978: 22). Dado que a visão geral é de que o extrativismo e o sistema de aviamento desestruturaram as sociedades da região, os autores tendem a ver esses coletivos como formações antigas, desaparecidas daqueles que não as possuem, ou enfraquecidas entre os que ainda guardam as suas referências.

Somam-se a isso as tentativas de generalizações que foram estabelecendo equivalências entre sufixos de diferentes populações, como se eles fossem as mesmas coisas, isto é, como se indicassem um mesmo processo. Nesse sentido, temos Gordon afirmando, em diversos momentos, tais equivalências entre línguas e populações diferentes, mas que participariam da mesma família linguística: “_madi é também um coletivizador equivalente ao _deni” (2006: 51); “_dawa [suruwahá], assim como madiha kulina [...] pode ser traduzida aproximadamente por 'gente', 'povo' ou 'dono' " (: 6). A questão não é dizer que são coisas diferentes, já que, mesmo que o tenham sido originalmente, a relação dessas populações com os brancos e seus registros deve ter ajudado na sua cristalização enquanto uma mesma coisa, que se relacionaria com as nossas crenças sobre grupos sociais.

A partir do momento em que coleções de nomes foram registradas em relatórios, artigos e publicações, os agentes externos, viajantes, exploradores, missionários,

${ }^{196}$ Chaves (2001) aponta que o SPI estimava em 1953 que existiriam 1000 "Bucuré-Deni”. 
funcionários do SIL, ONGs, governo, passaram a empreender buscas para contatar os membros dos supostos grupos existentes, favorecendo a manutenção de sua existência. Após o estabelecimento do contato inicial com determinada população, todas as informações que os agentes do contato obtinham sobre a presença de outras pessoas indígenas na região, era fornecidas por esta. Isto quer dizer que, primeiro surgia o indicativo sobre a existência de alguma população, que, posteriormente, os brancos procuravam contatar, ou, quando o encontro casual ocorria, o grupo até então desconhecido eram classificado segundo uma das possibilidades existentes.

Se atentarmos para a literatura histórica sobre a região, vemos que Jama.madi ${ }^{197}$, termo que discutimos acima, é uma forma fixada já no século XIX (Hyama.mady Coutinho 1862; Jama.madys - Chandless 1866, Yama.madi - Ehrenreich 1948). Registros de identidades de terminologia _deni surgem com as viagens do SPI, cujos registros mais antigos, até onde sabemos, são mencionados por Chaves: “em 1912 [...] No rio Inauini, o Sr. Castro e Silva identificou os seguintes subgrupos Jamamadis: 'Macuhi.denin, Ivé.denin, Bivacu.denin, Dema.denin, Tamacuhi.denin, Zuvazuva.denin e Eréqué.denin'." (divisão dos nomes nossa. 2001: 13). Um relatório do SPI de 1930 menciona os Araça.daini nos rios Coxodoá e Aruá. Tastevin, criticando a denominação Kulina, aponta que eles se chamam propriamente de 'Madiha' (os homens), tendo seu etnônimo sido dado possivelmente pelos Katukina, e que "como todos os índios eles se dividem em grupos totêmicos que portam cada um o nome do animal totêmico seguido pela palavra Madiha" (1924: 422), citando os Zuwihi-Madiha, Kamanui-Madiha, Tusipa-Madiha, Ete-Madiha, Dapu-Madiha, Hawa-Madiha.

Os sufixos madi(ha) e deni não correspondem, pura e simplesmente, a equivalentes, ao menos, possivelmente, não eram antes de passarem a existir e significar no contexto das relações com os brancos e outras populações indígenas que se transformaram em grupos étnicos. Após a fixação de designações de um ou outro tipo, elas ganharam o estatuto de grupo nesse contexto, ou seja, embora, inicialmente, designações de tipo deni e madi(ha) pudessem indicar outras coisas, acabaram por ser convertidas em designações de um mesmo tipo, marcando diferenças que não existem enquanto um conteúdo. Este parece ser o caso Deni, no qual não existe mais um processo ativo de formação de novos coletivos da alteridade humana e não surgem novos subgrupos de tipo_deni, os recortes da alteridade são, agora, dados pelos

${ }^{197}$ Marcamos, nesse parágrafo, a separação entre nomes e sufixos. 
próprios designados, que indicam suas identidades. Ao se conhecer um indígena que diz ser da etnia Tukano, os Tukanodeni passaram a figurar como uma possibilidade referencial.

Se havia, antes, um potencial de fracionamento dos subgrupos (Gordon 2006: 66), ele não estaria mais atuante no contexto Deni. Nada impede, contudo, que os Deni sejam desviantes, já que, com a grande maioria de suas aldeias ultrapassando os 100 moradores, eles não seguiriam nem mesmo o "padrão de dispersão socioespacial" (Gordon 2006: 66) a que os grupos Arawá teriam retornado após a demarcação de suas terras. Não há como saber se os Deni representam um caso anômalo, pois não há descrições apropriadas sobre modo_deni e_madi(ha) de construir coletivos para os Kulina e os grupos Jamamadi de língua próxima do deni e kulina. Podemos, contudo, considerar o caso Suruwahá, visto que a etnografia de Azevedo (2012) aborda a questão. A apreciação do caso Suruwahá, dentro de uma análise do tema entre os Arawá, foi, recentemente, realizada por Aparício Suarez (2013), a partir de sua pesquisa etnográfica.

Azevedo (2012) afirma que os Suruwahá dividiriam os grupos humanos em três macro-conjuntos: um deles marcado pela utilização da terminação _madi (de uso opcional em alguns casos); outro pelo uso do sufixo_dawa; e um terceiro composto por populações que não recebem nenhum marcador. Existem apenas dois povos cujos nomes não admitiriam o uso de sufixo: os Zama Iximini Zamaru (“coisa que tem rabo"), um povo canibal das cabeceiras dos rios Cuniuá e Coxodoá que a autora não conseguiu relacionar com nenhuma população conhecida, e os Juma, que ela identifica com sendo "um (ou vários?) grupo(s) tupi-kawahib que ocupava(m) um território vasto localizado entre os rios Piranhas, Ipixuna, Içuã, Mucuim e Jacaré” (2012: 86).

A questão dos Juma é interessante, pois, muitos autores identificam esses personagens em outras cosmologias arawá, como os Paumari (Joima - Salzer \& Chapman 1998 e Bonilla 2007) e os Jarawara (Yima - Vogel 2006 e Maizza 2012). Entre os Deni, não obtivemos informações sobre os Juma, mas muitas narrativas tratam dos Zumahi, termo que, com as devidas adaptações, faz referência à onça nas diversas línguas arawá. A palavra Zumahi apresenta semelhança fonética com Juma, pois o som de "J" em português não existe na língua deni, sendo comumente associado com o som do “Z”. As onças Deni apresentam o mesmo comportamento agressivo, guerreiro e 
canibal atribuído, por outras populações da região, aos Juma, como descrito por Bonilla (2007) e Azevedo (2012).

Deixando de lado esses dois casos nos quais que os Suruwahá não usam marcadores, temos o emprego dos sufixos madi e dawa para realizar recortes da alteridade. Azevedo apresenta diferentes "povos dos quais_madi é um componente fixo" (2012: 84): Aba.madi ${ }^{198}$, Za.madi ${ }^{199}$, Jaki.miadi ${ }^{200}$, Kaxijai.madi. Estes dois últimos não são formados por palavras da língua suruwahá mais o sufixo, isto é, jaki e kaxijai não possuem significado em suruwahá. Para outros coletivos, o termo madi é um componente facultativo, estas são populações com as quais os Suruwahá tiveram contato em anos recentes: Dini[madi] (os Deni); Katukina[madi] (uma população também chamada Katukina pelos não indígenas da região).

Azevedo apresenta uma lista de nomes dawa, caracterizados como "subgrupos nomeados '_dawa', cada um dos quais [possuindo] seu próprio território e [ocupando] um conjunto de várias malocas" (2012: 89): Sarahadawa, Zama Kaxuhudawa, Tybydawa, Kurubidawa, Masanidawa, Sarukwadawa, Idiahindawa, Madidawa, Jukihidawa, Tabusurudawa, Adamidawa, Nakanidanidawa, Zamadawa e Wahadawa. Estes dois últimos seriam "falantes de uma língua "não totalmente compreensível" (2012: 91). A autora afirma que a denominação dawa corresponde à forma singular, sendo necessário o acréscimo do sufixo madi ao final para indicar o plural (2012: 92).

Segundo Aparício Suarez (2013), o sufixo midi (para Azevedo é madi ou miadi) seria uma transformação de madi, usado para compor coletivos diversos, como "as mulheres" (haji.midi), "os jovens" (wasi.midi), "as crianças" (ha.midi), etc.. O único nome que seria uma espécie de etnônimo com terminação midi, fornecido pelo autor, é Jaki.midi (para Azevedo Jaki.miadi). Dado nosso desconhecimento da língua suruwahá, não podemos afirmar que midi, miadi e madi sejam formas diversas para expressar um mesmo significado, ou que sejam a mesma coisa e suas variações sejam devidas, apenas, à fonologia da língua.

A partir dos dados de Azevedo, é possível inferir que a distinção entre _dawa e _madi não estabelece um grande divisor de natureza linguística, pois entre os dawa há, para os próprios Suruwahá, aqueles que não falam a sua língua. Entre os madi e os

\footnotetext{
${ }^{198}$ O povo-peixe.

199 Corruptela de zama.madi.

200 Segundo a autora: "-miadi é um alomorfe de -madi usado depois de sílabas que terminam em $i$ (nas palavras em que -madi funciona como enclítico).” (2012: 84).
} 
dawa há nomes cuja parte inicial não possui significado no idioma, sendo alguns dos madi corruptelas das autodenominações de outras populações indígenas, o que não se observa nos dawa. Aparício Suarez (2013), em relação a essa questão, argumenta que, em certos contextos, madi indicaria uma coletividade mais distante, da categoria dos afins potenciais e dawa expressaria coletivos próximos, afins reais; enquanto, em outros contextos, madi serviria como um coletivizador genérico e dawa como um coletivizador específico. Embora não discordemos dessas associações, parece apropriado considerar madi e dawa situando-se em níveis diferentes.

Ainda segundo Aparício Suarez (2008), há uma divisão binária no pensamento Suruwahá entre os jadawa ("nós") e waduna (os outros, os estrangeiros), havendo um escalonamento entre o próprio dawa (jadawa), os outros dawa e os waduna (os madi), correspondendo a círculos concêntricos recortando a distinção nós/eles. Em outro nível, contudo, todos são madi, seja os waduna (que são distinguidos como madi) quanto os dawa (que seriam descendentes dos Sara.madi). A divisão dawa é, assim, interna a uma divisão de tipo madi, mas só torna-se relevante entre aqueles que são Suruwahá, isto é, somente do ponto de vista de dado Ego é que se constituem os dawa, ou seja, dawa são aqueles posicionados em meio a uma rede de relações positivas.

Claro que, pelas informações de Azevedo (2012), alguns agrupamentos inseridos nessa rede relacional não eram propriamente falantes do suruwahá: os Zamadawa e os Wahadawa. Aparício Suarez (2008) esclarece, contudo, que os Zamadawa participavam do universo relacional enquanto fornecedores de ferramentas (no modo troca?), intermediários da relação entre os dawa falantes do suruwahá e os Jara (brancos) de quem obtinham os bens. A partir do desaparecimento do último dos Zamadawa, os dawa estabeleceram relações no modo predação para obter as ferramentas.

O autor aponta, entretanto, que existiriam "unidades que não são nomeadas com o sufixo dawa, mas que faziam parte desta rede de construção de alteridades: os Anizakawa, os Suruwahá ${ }^{201}$ e os Aijanima madi” (Aparício Suarez 2013), e estes, pelas informações disponíveis, não se relacionam propriamente com os dawa. Os Anizakawa fazem guerra com os Jakima (Aparício Suarez 2008) e esta é a única informação sobre a participação deles na rede relacional, logo, não se trataria de uma população em contato

\footnotetext{
${ }^{201}$ Aparicio Suarez fornece a forma Suruaha made (2008: 123), eles seriam também uma divisão de tipo madi.
} 
com os dawa. Por esses motivos, as identidades de tipo madi e dawa parecem não corresponder a uma mesma coisa, não são sinônimos.

Aparício Suarez assinala que os dawa

"até o início do século $\mathrm{XX}$, se identificavam com um território específico, organizado em torno a um rio ou igarapé, possuíam uma unidade residencial com roças próprias, e falavam dialetos de uma mesma língua. Havia frequentes intercâmbios rituais e relações de aliança, junto a uma política xamânica marcada pela feitiçaria intergrupal, perpassada de tensões e conflitos.” (2013:)

A relação entre os dawa era perpassada por diversas dimensões: troca, aliança, xamanismo e conflitos. As conexões entre eles não se resumiam aos encontros esporádicos e a troca de violências, mas, estabeleciam uma rede de relações formadas por muitos vínculos duráveis, envolvendo casamentos inter-dawa.

Azevedo (2012) afirma que o sufixo _dawa "evoca três ideias: a ideia do domínio (sobre algo), a ideia da especialização (em algo) e a ideia do ajuste da conduta a certos padrões 'eternos/ ideais', tidos como 'inerentes à natureza do ser'” (2012: 93). Não temos competência linguística em suruwahá para comentar apropriadamente estas afirmações, ou se _dawa tem, enquanto sufixo, enquanto uma terminação ligada a um substantivo (relacionado com a primeira ideia), o mesmo valor de quando aparece como um afixo de terminação verbal ou de quando "ocupa o penúltimo lugar dentro do sintagma verbal" (2012: 93). Não podemos afirmar se a primeira ideia, ligada ao uso de _dawa junto a substantivos, se relaciona diretamente com as outras duas, quando é utilizado enquanto afixo verbal.

É interessante notar que todos os três usos, e os exemplos apresentados, carregam o sentido de durabilidade, não sendo aplicáveis a ações casuais, mas, antes, àquelas que definem algo (como o agricultor kama[plantar].dawa, que só se aplica a quem planta todo ano). As identidades dawa aparecem, assim, inscritas no universo de relações permanentes. Por exemplo, quando se menciona os Ariria Hawadawa ${ }^{202}$, o povo daqueles que comiam frequentemente os dawa do narrador, o enunciado estabelece a existência de um grupo situado no mundo, com o qual se mantinha uma

\footnotetext{
202 “Ariria= nós (acusativo); hawa- 'comer'; -dawa 'sujeito que realiza a ação descrita no verbo frequentemente"” (Azevedo 2012: 96 nota 91).
} 
relação de predação. O que a nomenclatura aponta é a existência de uma relação que se desenvolve no tempo.

A partir dos dados disponíveis, é possível entender, não apenas, que dawa era uma identidade atribuída àqueles com quem se mantinha relações permanentes e que possuíam uma localização geográfica delimitada, mas, também, que esta identidade existia para os Outros a partir de uma determinada posição, de um ponto de vista. Alguns dawa são ligados a determinado rio ou igarapé ou região, mas, há outros que só podem existir se for assumido um ponto a partir do qual eles são apreendidos, que dizer, é necessário que exista uma referência fixa para nomeá-los. Como aponta Aparício Suarez, há a "gente do leste" (Masanidawa), a "gente do outro lado do rio" (Idiahindawa), ou seja, gentes que não poderiam de forma alguma se referir a si mesmas destas formas, já que suas nomenclaturas pressupõem um observador externo fixo localizado no oeste e/ou do outro lado do rio e que, desta forma, podem atribuir tais nomes para eles.

Já indicamos acima que os dawa, para serem considerados como um coletivo, devem ser acompanhados pela terminação madi, ou seja, com aqueles que se mantêm relações (os dawa) é possível distinguir entre a relação com seus membros componentes (cada um dos dawa) e aquela em que os termos tornam-se multiplicidades singulares (um dawa no modo madi). Esse tipo de distinção não se mostra possível no caso dos madi, pois, como aponta Azevedo, uma "conseqüência gramatical interessante da incorporação do substantivo madi aos etnônimos Abamadi, Zamadi e Jakimiadi [...] é a impossibilidade de estabelecer uma distinção nítida entre ações coletivas e individuais" (2012: 87-88). Possivelmente, esta indistinção não existe ao nível de distinções madi, o um e o múltiplo não correspondem a coisas diferentes, toda pessoa madi participa de uma entidade em que ela não existe enquanto uma unidade, um indivíduo. Os dawa, quando se tornam madi, transformam-se em uma entidade que se relaciona com outros madi, já aqueles que são exclusivamente madi nunca se relacionam com os dawa, mas apenas com os dawa no modo madi, ou seja, são entidades supra pessoais que entram em relação e, não, pessoas que fazem parte de grupos diferentes.

Voltemos aos sufixos_deni e_madi no contexto Deni. Atualmente, não se aplica corriqueiramente_madi como terminação, estando presente somente em algumas narrativas situadas no tempo passado que é descontínuo em relação ao presente. Comumente, quando estão nas narrativas, os termos compostos com _madi não são 
traduzidos, sendo encarados como nomes próprios e não como substantivos traduzíveis. A única exceção talvez seja o Bithamadi, especificado, por alguns, como sendo "a gente do pium" quando se fala em português, mas seu nome não é sempre incluído na história. Neste caso, Bithamadi não corresponde a uma coletividade de pessoas e sim a um monstro (que é uma pessoa) que contém em si os piuns, os mosquitos e mutucas, isto é, um humano formado por não humanos ${ }^{203}$. Em certa medida, não há, aqui, muita diferença em relação a qualquer pessoa humana que é formada pela sua infinidade de almas, nenhuma das quais é a pessoa.

Temos informações sobre duas outras identidades _madi: os Dii.madi.deni, mencionados anteriormente, e as Panapana.madi.deni, as Amazonas ${ }^{204}$. As narrativas em que eles figuram, porém, apresentam, também, possibilidades em que são nomeados sem madi, ou seja, há versões em que são nomeados de Dii.deni e Panapana.deni. Madi parece ter perdido seu valor de sufixo adjetivador, que dava uma qualidade de coletivo a um substantivo, embora se mantenha como um termo independente, substantivo e/ou um adjetivo que indica um coletivo, não propriamente um conjunto, mas uma multiplicidade que é ao mesmo tempo uma unidade.

Na ideia de madi, há certa semelhança com o que Cesarino (2008) aponta para os Marubo: uma replicação das pessoas/aldeias pelo cosmo. Para os Marubo, todo “corpo/gente têm dentro de si duplos que são eles próprios gentes/corpos" (:34), sendo o corpo o local em que habitam duplos variados, marcado antes pela diferença interna do que pela semelhança. Há relações entre os diferentes habitantes do corpo/aldeia, parecendo ser este o foco, um cotidiano interno replicando o cotidiano da aldeia ${ }^{205}$. O corpo/casa apresenta uma unidade na figura do seu chefe, mas unidade "quer dizer exemplaridade (o chefe de uma maloca) e não isolamento" (39), isto é, o dono da maloca/corpo que não pode se exteriorizar é o que representa a maloca. Não sendo formada por partes componentes, a pessoa não é uma espécie de sociedade delimitada e fechada, pois seus próprios moradores podem vir a abandonar esta localidade para mudar de casa, tal como uma pessoa pode vir a mudar seu local de habitação.

\footnotetext{
${ }^{203}$ Os piuns não são e nem nunca foram gente, humanos, o mesmo podendo ser válido para os mosquitos e mutucas. É interessante notar, contudo, que o monstro é caracterizado por possuir uma barriga muito grande, algo que se observa nos insetos hematófagos após se alimentarem. Os diminutos piuns chegam a triplicar seu tamanho após sugarem o sangue de suas vítimas.

${ }^{204} \mathrm{Um}$ grupo formado apenas por mulheres que matam todos os homens com quem entram em contato, inclusive os bebês do sexo masculino.

${ }^{205}$ Cesarino fala propriamente da pessoa Marubo como uma entidade que "replica as dinâmicas do parentesco" (2008:37), reproduzindo o exterior no interior.
} 
Para os Deni, madiha (uma pessoa) é, em si, uma multiplicidade, na qual existem, entre outras coisas, infinitas almas ( $a b a n u)$, mas uma dentre elas é uma espécie de chefe, a alma verdadeira que possui um devir, um destino post mortem positivo. Não há diferenciação entre os abanu, embora se manifestem de formas variáveis, como sombra, como reflexo na água, na fotografia, enquanto a pessoa estava viva, todos são iguais. Os abanu podem tornar-se exteriores ao corpo, vagar pelos locais já conhecidos por uma pessoa, serem fixados em fotografias, destruídos, comidos, mas não podem passar para outra morada corporal, apenas quando a relação de predação, tornando-se alimento de alguma outra entidade, mas, nestes casos, há uma desintegração da pessoa/corpo, levando a sua morte. Um madiha é, assim, uma multiplicidade indiferenciada, onde há muitos semelhantes que parecem não formar propriamente uma aldeia, como no caso Marubo, parecendo não haver interação entre os abanu de uma pessoa.

Talvez seja devido a uma limitação de nosso conhecimento (e dos não xamãs com quem conversamos sobre o assunto) que não tenham sido relatadas interações entre os diferentes abanu pessoais, apenas uma distinção entre as múltiplas projeções que vagam pela terra após a morte e o abanu verdadeiro, que irá seguir para uma das aldeias do céu ou da água. A questão parece ser que madiha é um englobamento hierárquico de muitos e isso se replica ao nível madi. Assim como os madiha, ao nível externo, diferem entre si, mas, no interno, onde formam uma multiplicidade indiferenciada, ao nível madi os madiha (pessoas) são indiferentes entre si, mas um madi difere em relação a outro madi e suas pessoas.

Nesse sentido, é possível compreender por que os Deni afirmam que são misturados ao mesmo tempo em que não o são: por um lado, eles são diferentes madiha de diferentes subgrupos, mas por outro, são de apenas um madi, podendo sua singularidade ser distinguida de outras, pois Deni é uma singularidade formada por uma multiplicidade dos mesmos e não dos diferentes, a língua é uma só, seus corpos são semelhantes, todos veem os ари como apu. Há diferentes subgrupos em sua composição, mas todos são feitos de um mesmo substrato, são todos Deni; esta noção de indistinção intra-Deni se situa na distinção frente aos madi não Deni e aos não madi (os kariva). Deni, dessa forma, seria uma entidade composta por diferentes subgrupos madi (fixadas pela história de contato/registro dos brancos como subgrupos_deni), mas 
que são todos passíveis de serem apreendidos como não-diferentes quando em relações com Outros que falem outra língua, que não apreendam o mundo da mesma forma.

Para se referir a diferentes madi, usa-se a expressão madi uvaa. Uvaa, nesse contexto, é comumente traduzido por "outro", mas há nisto certa imprecisão. Uvaa é sim, outro, mas isto indica a existência de uma base comum, que permite que ele seja outro que é semelhante. O termo se aplicada para indicar o "irmão dele", o irmão é "outro", mas que guarda uma semelhança com a pessoa referida, semelhança que está no corpo e no cheiro ${ }^{206}$, na constituição da própria pessoa. A germanidade, aqui, como parece ser em toda a Amazônia, marca-se como o menor grau da diferença. Seu uso indica alteridade, mas ela não é tão diferente como suporíamos. Pela simples tradução de madi uvaa como outra gente, estaria perdida a ideia de uma quase identidade entre eles. É preciso considerar o limite da identidade madi, que está situado, atualmente, na ideia de que todos os indígenas são madi, mas os não indígenas não o são, eles são outra coisa: kariva ou bani.

Deixando os animais de fora, pois eles não são de forma alguma humanos, há, de um lado, os madi, e de outro, os kariva; aqui há uma marcação de uma diferença em que quase não há semelhança, visto que os kariva são humanos no limite. O idioma da consanguinidade já não se aplica na relação, pois, para um madi, os kariva não são outros como irmãos, eles são situados na relação de afinidade, são cunhados, afins com quem não se estabelece uniões matrimoniais ${ }^{207}$. Para os madi, os kariva se situam no plano da afinidade virtual, da afinidade sem afins efetivos. Como já apontou Viveiros de Castro (2002), afinidade e consanguinidade se colocam em uma relação hierárquica na Amazônia, aqui, portanto, temos os Deni como um grupo madi de consanguíneos, para quem os kariva exteriores são afins.

As outras populações indígenas, como já apontamos, possuem um status geralmente ambíguo: não tão são parentes como os próprios Deni, nem tão afins quanto os kariva. Com os outros indígenas, podem ser estabelecidas uniões matrimoniais apropriadas e duradouras, mas, muitos deles, passaram a ser quase kariva, então a possibilidade de serem tomados como uma singularidade madi estaria comprometida.

\footnotetext{
${ }^{206}$ Veja próximo capítulo

${ }^{207}$ Os casos de casamento entre Deni e Kariva são sempre problemáticos, existindo muitos casos em que as uniões são desfeitas pela ação dos parentes do/a indígena. Só um caso parece perdurar, em uma aldeia do Xeruã na qual um homem Kariva co-residente está casado com duas mulheres Deni, mas este homem teria, desde criança, convivido nas aldeias Deni, sendo, possivelmente, um quase-madiha antes de contrair matrimônio.
} 
Aqui, nos situamos nos limites, e como os Deni não têm a nossa preocupação ocidental moderna de estabelecer padrões e categorias sempre válidas, a ambiguidade é evidente: os casos limites ora têm seus aspectos indígenas ora seus aspectos de semelhança com os kariva evidenciados. Na ausência de nossa crença na miscigenação, os Outros serão sempre enunciados de acordo com a relação em foco.

Os próprios kariva possuem identidades que se processam da mesma forma que os madi: em certo nível, todos são kariva, em outro, há aqueles que são americanos, kariva de fala ruim (falante do espanhol) e os kariva mesmo (os brasileiros). Aqueles que são kariva ao nível da fala, isto é, os brasileiros, situados no mesmo nível em que os Deni se diferenciam dos outros madi, são, por sua vez, separados em diferentes tipos deni: missionáriodeni, funaideni, funasadeni, cimideni, opandeni, greenpeacedeni, etc. Mas, estas mesmas divisões existem virtualmente entre os americanos e os kariva de fala ruim, há americano missionário, americano greenpeace, etc...

É interessante notar que, nos múltiplos níveis ${ }^{208}$, existem chefes $^{209}$ que estão relacionados aos diferentes patamares em que uma perspectiva se estabiliza. No nível madi $=$ indígenas, associação que surgiu, provavelmente, no curso da participação no movimento indígena, há o patarahu (chefe) que é o presidente da organização indígena da região; no nível madi = Deni parece, também, haver um patarahu, hoje, há uma espécie de representante eleito ${ }^{210}$ para todas as aldeias do Cuniuá e os relatos da fusão dos subgrupos apontam que ela se processou em torno de um grande chefe. No nível da pessoa madiha, há a alma (abanu) que é a de verdade, a principal, que possui um destino post mortem especial. Nas aldeias, há o chefe, mas nesse nível não se estabelece atualmente uma identidade de tipo madi, que é explicitamente negada. Segundo os discursos, uma aldeia, hoje, não corresponderia nem a uma unidade madi nem a uma

\footnotetext{
${ }^{208} \mathrm{O}$ mesmo acontece entre os kariva: há o Lula que é o patarahu dos kariva (quando de nossa pesquisa de campo), o patarahu da FUNASA, o da FUNAI, do CIMI, da OPAN, dos missionários, dos americanos...

209 Até entre as queixadas, os madi não humanos, os Deni apontam que há sempre uma espécie de chefe que anda na frente do bando. Ele é Hamu, um humano que teria se casado com as queixadas e se tornado uma delas. As queixadas são os únicos animais que, tal como os humanos, se constituem em um grande número, sendo curiosamente chefiadas por um humano que passou a viver com elas.

${ }^{210}$ Foi uma eleição organizada pelos missionários para preencher a vaga de conselheiro distrital de saúde. Os Deni, contudo, se referem a ele da mesma forma usada para um chefe de aldeia e na prática este chefe nunca participa das reuniões do conselho distrital, atando no movimento indígena e junto a FUNAI.
} 
unidade deni e, de fato, à exceção da co-residência, ela não seria uma unidade conceitual de qualquer tipo ${ }^{211}$.

Ao nível das comunidades locais, há indistinção de subgrupos, de identidades de tipo deni. Deni é um sufixo pluralizador ligado, invariavelmente, aos humanos; isto serve para os gêneros ${ }^{212}$, para as pessoas ${ }^{213}$, parentes $^{214}$, pronomes $^{215}$ e partes do $\operatorname{corpo}^{216}$. Quando aplicado a substantivos não humanos, indica que se trata, na verdade, de humanos, isto é, são os subgrupos mencionados pela literatura e não uma coleção de determinada coisa. Estas identidades parecem ser, originalmente, ligadas a determinadas localidades especificas, o que ainda é perceptível para muitos dos subgrupos presentes atualmente entre os Deni. Isto é particularmente evidente em dois deles, cujos referenciais territoriais não se perderam: os Upanavadeni que, como já havia registrado Koop \& Lingenfelter, "são os Deni do rio Upanava" (1983: 1) e os Kunivadeni, que são aqueles do rio Cuniuá (Kuniva).

A construção de identidades em função do nome de localidades é vista, pelos Deni, como um fenômeno que acontece em toda parte do cosmos humanos, pois, outras populações também são nomeadas de forma semelhante. Os Deni afirmam, por exemplo, que os Banawá, reconhecidos como uma unidade distinta, correspondem a uma população que mantém suas características de madi. Os Banawá, porém, são tidos pelos Deni como sendo, na verdade, Jamamadi, tendo determinada aldeia/unidade se estabilizado enquanto uma identidade distinta, de nome Banawá, em função do nome do igarapé em que construíram suas aldeias, chamado Banawá. Os Jamamadi, para os Deni do Cuniuá, são uma entidade para além dos seus grupos locais, eles são um madi, mas a mesma lógica se aplica aos Banawá, que também são madi, embora num nível maior, quando são contrapostos aos Deni, eles são Jamamadi. Banawa, desta maneira, corresponde a uma espécie de subgrupo _deni, que passa a ser Jamamadi em relação com os Deni, enquanto coletivo_madi.

\footnotetext{
${ }^{211}$ Talvez a exceção seja a aldeia Sikuriha, formada pelos filhos, genros/noras e netos de seu fundador. É a menor aldeia Deni, com 31 moradores em 20 de junho de 2011.

${ }_{212}$ Por exemplo, amunehe (mulher) torna-se amunehedeni (mulheres) quando se considera no discurso mais de uma, isto é, duas, três ... ou todas as mulheres.

${ }^{213}$ Quando se fala de uma pessoa não especificada ou desconhecida, usa-se madiha, já quando se fala de várias, usa-se madihadeni. Para as crianças, uma é eheve, mais de uma é ehevedeni.

${ }^{214}$ Essa lógica se aplica para "parentes" (uvibuva e uvibuvadeni) e para todos os termos de parentesco. Por exemplo: meu filho = ukhadau e meus filhos = ukhadaudeni .

${ }^{215}$ Apenas para a segunda e terceira pessoa. Por exemplo nos pronomes pessoais: você (tia) e vocês (tiadeni), ele (рua) e eles (puadeni), ela (puni) e elas (punideni).

${ }^{216}$ Por exemplo, uzepe (minha mão ou meu dedo) e uzepedeni (minhas mãos ou meus dedos).
} 
Um dos irmãos tamakurideni ${ }^{217}$ fundadores da aldeia Cidadezinha, em diversos momentos, indiciou que ali era tamakuri, que ele havia sido o primeiro a abrir um roçado no local e, por isso, ali era tamakuri. Possivelmente, o processo de composição da toponímia levava em conta o grupo que deu origem a uma comunidade em determinado local, que passaria, então, a possuir o seu nome, isto é, as identidades deni não seriam sempre fruto de uma associação de pessoas com determinado local, mas as localidades também seriam nomeadas em função do grupo que lá se estabeleceu. Neste caso, teríamos um referencial topográfico informado a partir daquele que se estabeleceu inicialmente na localidade, mas não sabemos dizer se este era um processo comum. No entanto, há algumas pessoas que têm seus nomes compostos pela terminação $d e n i^{218}$, e, talvez, se eles fundassem aldeias ${ }^{219}$, passariam a informar o nome do local e do subgrupo associado.

A toponímia da região frequentada pelos Deni é, em grande medida, baseada em nomes em português, o que se faz presente mesmo nos nomes das aldeias: Cidadezinha, Marrecão, Volta Grande, Vi(s)agem, Samauma, Boiador, Morada Nova, Terra Nova, Buzina $^{220}$. Não pudemos descobrir a origem dos nomes de todas estas, apenas da Marrecão, cujo nome surgiu a partir do igarapé homônimo, e da Viagem que deriva de uma visagem (espécie de fantasma no português regional) vista no local. A aldeia Marrecão já se movimentou pelo Cuniuá, mas seu nome permaneceu inalterado. Os Marrecãodeni (mahekaudeni), forma pela qual os moradores de outras aldeias se referem aos seus moradores, criaram uma nova comunidade e esta permanece Marrecão, sua identidade perdurando para além da associação com o igarapé homônimo. Neste processo, a fixação de determinado deni passa a imprimir um nome sobre a localidade; não seriam os grupos nomeados a partir da geografia, mas seriam eles que comporiam a toponímia regional.

Como dissemos anteriormente alguns dos nomes_deni foram cristalizados e fixados, muito provavelmente em função das relações com os kariva, quando uma

\footnotetext{
${ }^{217}$ Tamakuri é uma espécie de macaco.

${ }^{218}$ Alguns desses nomes são formados por elementos naturais acrescidos do sufixo deni, como Havadeni (hava=patauá), mas outros não, como Muthadeni (mutha $=1$ (adv.) mesmo, mesma; somente, exclusivamente. 2 (adj.) só, exclusivo Koop \& Koop 1985).

${ }^{219}$ Não podemos dizer nada sobre como seria no passado, mas as cisões mais recentes de que temos noticias, e que constituiriam aldeias de longa duração, foram feitas a partir de um casal e/ou seus descendentes (um grupo de siblings). Assim teriam surgido as aldeias Sikuriha e Volta Grande, a partir de cisões originárias da aldeia Viagem.

${ }^{220}$ Alguns desses nomes corresponderiam a aldeias antigas mencionadas por Chaves (2001).
} 
categoria topográfica relacional passou ao status de uma identidade madi. O processo de surgimento de identificações de tipo deni permanece e, tal como os dawa Suruwahá, ele depende de ser assumido um ponto a partir do qual se traçam as relações. A partir da aldeia Cidadezinha, há os Marrecãodeni, Zunametedeni, Voltadeni, Sikurihadeni, Samaumadeni, Xeruvadeni e, embora sejam unidades deni presentes nos discursos e surgidas a partir de relações estabelecidas, elas não são reconhecidas como constituindo algo como um "tipo de gente".

Os moradores da Cidadezinha nunca dizem ser Cidadezinhadeni, assim como todos os outros que receberiam uma identidade semelhante (Marrecãodeni, Viagemdeni, Xeruvadeni, etc.) tendem a negar sua existência. A própria identidade Upanavadeni, reconhecida por todos, é negada pelos próprios Upanavadeni, que se dizem Bukuredeni. A questão parece ser mesmo que algumas das designações deni tornaram-se semelhantes às identidades madi, aquelas que, a partir do presente, são concebidas como unidades endogâmicas e que, antigamente, mantinham a guerra de aniquilação como única relação possível. Foi a partir do fim dos conflitos entre elas que se constituíram os Deni, quando a guerra passou a ser dirigida aos Outros-madi e as perspectivas foram conciliadas (agora todos veem o $а р и$ como $a p u$ ). Por sua vez, o surgimento dos kariva é associado ao estabelecimento de uma paz intra-humanos, que agora se relacionam enquanto identidades deni, isto é, enquanto coletivos humanos que se relacionam de forma pacífica. Neste contexto surgem os Paumarideni, Makhukhudeni (Suruwahá), Apurinãdeni, Jamamadideni, uma série de madi que agora mantem relações positivas e continuas, tornando, também, coletivos madi.

Podemos, agora, entender a diferença de auto-identificação entre os Deni do Cuniuá e os do Xeruã apontada por Chaves (2001) e atribuída à ação do SIL (Kroemer 1995) ou dos missionários (Chaves 2001), mas negada pelos últimos ${ }^{221}$. Se, quando Chaves esteve no Xeruã, os habitantes deste rio se identificaram como Jamamadideni e os do Cuniuá como Madihadeni, isto pode ser entendido pela presença dos Kulina, chamados de Madihadeni, no Xeruã/Juruá e dos Jamamadi no Cuniuá/Purus. Identidades deni marcam sempre os Outros; tanto Madihadeni quanto Jamamadideni, enquanto formas de auto-identificação, só podem existir enquanto um contraste. $\mathrm{Na}$ necessidade de ser algo para os kariva, os Deni apresentam nomes que indicam serem

\footnotetext{
${ }^{221}$ Veja explicação do missionário Vladmir Cunha no site do ISA (http://www.socioambiental.org/piinterno/epi/deni/nome.shtm em 27/03/2013).
} 
os Outros dos Outros com quem estão em contato, logo, precisam se diferenciar dos seus Outros regionais, tanto que o etnônimo Deni foi plenamente assumido nas relações interétnicas. Assim, são Deni quando precisam se identificar, porque são Deni para os Outros.

Madihadeni é um termo que surge nos discursos que pessoas dirigem aos seus co-residentes, as outras pessoas da aldeia, de uma forma em quem fala (o emissor) não está incluso (os madihadeni são os outros madiha), já que, para se incluir, o emissor

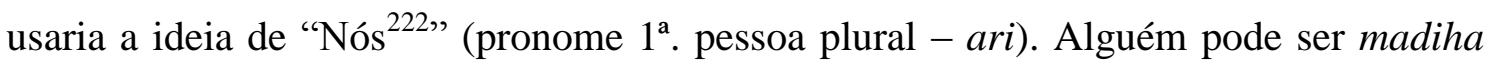
(“eu sou madiha”), já madihadeni são, necessariamente, os outros madiha que não o autor da enunciação. Isto é evidente quando investigamos o que seria madideni ${ }^{223}$, tal noção corresponderia a todos os madi que não aqueles da localidade. Na Cidadezinha, ponto a partir do qual estávamos nos situando no cosmos, madideni abarcaria os Paumari, os Apurinã, os Deni do Xeruã, os moradores da aldeia Marrecão, etc., mas não os moradores da Cidadezinha. O termo não poderia ser traduzido por indígenas, ou nãokariva, ou humanos, pois ele marcaria os Outros: os outros indígenas, os outros nãokariva, os outros Deni. Nesse contexto, em que se salientam os madi enquanto uma pluralidade e não uma singularidade - não se trata de uma unidade, mas de um conjunto formado por muitos madi - a própria aldeia, uma singularidade no plano ideal $^{224}$, se contrapõe a todas as outras, o uso do sufixo deni coloca em relação alguns termos: um Outro múltiplo (são Paumari, Apurinã, Deni do Xeruã, etc.); e um termo emissor que se singulariza enquanto uma identidade. A verbalização de madihadeni delimita uma pessoa (madiha) falando para as outras, a de madideni teria como emissor um madi.

No caso Kulina, a identidade de subgrupos parece ser aquela em que os recortes madi, muito semelhante ao modelo Deni que estamos delineando, se apresentam mais claramente. Até onde sabemos, a forma de delimitação de grupos pelo uso de madiha teve seu primeiro registro graças a Tastevin (Rivet \& Tastevin 1938), a partir de suas viagens pela região do rio Juruá, entre os anos de 1908 e 1914 (Tastevin 1919). Outros viajantes, exploradores e etnógrafos que entraram em contato com os Kulina também apontam para essa divisão interna em diferentes madiha, cuja nomenclatura é formada

\footnotetext{
${ }^{222}$ Não há na língua deni uma diferença entre um nós inclusivo (eu + você(s)) e um exclusivo (eu + ele(s)).

${ }^{223}$ Não conseguimos perceber esta noção sendo usada em discursos livres, podendo ter sido gerada pela investigação. Ela, contudo, fez sentindo, construindo uma ideia de conjunto que provavelmente nunca se constituiria enquanto sujeito ou objeto de ação, mas que seria conceitualmente inteligível.

${ }^{224}$ Mas que atualmente se concebe como uma mistura interna de diferentes.
} 
pelo nome de um animal ou vegetal ${ }^{225}$ seguido de madiha. Pollock aponta que seus “informantes são capazes de nomear 70 grupos madiha diferentes, embora alguns possam ser hipotéticos" (1985a: 38).

Os membros de alguns madiha, mas aparentemente não de todos, apresentariam características da espécie que dá nome às suas identidades (Townsend \& Adams 1973, Altmann 1994). Lorrain aponta que os matadores são considerados como cachorros (ette Madiha) e os xamãs assassinos como onças ('jaguares’ - dsomaji Madija). A partir das evidências empíricas é possível conhecer a identidade real de alguém: os matadores são onça, possivelmente, porque os dsomaji Madiha eram guerreiros reconhecidos ${ }^{226}$. Lorrain afirma que os Kulina do Envira foram nomeados dsotomi (quati) Madija pelos Kulina do Juruá e Purus devido à sua reputação de realizar ataques ardilosos como xamãs e guerreiros, tal como os quatis, que são dissimulados. A divisão madiha se apresenta, tal como a madi dos Deni, como uma singularidade para o exterior e se replica internamente em uma multiplicidade. Os matadores assumem a identidade do matador prototípico (a onça), um coletivo formado por uma indistinção de matadores em relação aos não matadores.

Os Kulina "normalmente afirmam que as aldeias são compostas por membros de apenas um único grupo madiha, embora um único grupo (ou categoria) madiha possa abranger várias aldeias" (tradução nossa - Pollock 1985a: 38). Não importa que, de fato, haja uma mistura de identidade interna à aldeia, todos seus moradores podem se identificar como o madiha da comunidade. A questão relevante não parece ser uma auto identificação substantivista com os membros do grupo, mas, antes, a possibilidade de eles serem uma singularidade para o exterior que se marca por uma indistinção interior. $\mathrm{Na}$ aldeia da gente do quati, todos são quati quando o foco esta na diferença entre esta e outras aldeias, mas seus moradores são outra coisa quando se enfatiza que os quati são diferentes dos peixes, embora vivam em uma mesma aldeia, e, por sua vez, as pessoas que são quati são diferentes entre si...

Viveiros de Castro (1978) afirma que "madiha é um conceito que opera em vários níveis de contraste" (: 18): enquanto pessoa, enquanto parente, enquanto Kulina, enquanto indígenas. Tais níveis seriam momentos em que uma singularidade (um

\footnotetext{
${ }^{225}$ A lista fornecida por Viveiros de Castro (1978) só contém nomes de animais e vegetais.

${ }^{226}$ Como vimos entre os Deni, a narrativa que envolve os zumahideni, os apresenta como guerreiros que procuram se envolver em guerras que não lhes diriam respeito inicialmente.
} 
conjunto transformado em uma entidade singular) pode ser contrastada a outras de mesmo tipo, num processo que se observa em todo o cosmos: pessoas diferentes são um mesmo subgrupo diferente de outros, mas que são o mesmo quando a relação é com os não Kulina, que são o mesmo quando a relação é com os brancos... Tal como ocorre no contexto Deni, uma dada identidade é replicada internamente, uma singularidade para o exterior (Um para os Outros) que é uma multiplicidade interior (conjunto de iguais).

Como aponta Silva, "os Madija agem comunitariamente o tempo todo e a aparente desorganização da aldeia cede lugar a uma profunda interação social onde todos participam de tudo o tempo todo" (Silva 1997: 125), ou seja, os madiha aparentam ser uma unidade quando vistos do exterior. Esta observação da indistinção foi formulada a partir da perspectiva do antropólogo não indígena, mas é compactuada pelos outros indígenas não-Kulina. Há, aqui, uma coincidência entre a forma Kulina de estar (objetivada pelos não-Kulina) e o seu modo de definir entidades, quando o ponto é o contraste com os não-Kulina. Para os Kulina serem percebidos desta forma indiferenciada, é preciso que eles estejam em uma relação com os não-Kulina.

A associação que os Kulina traçam entre seus madiha e as "identidades regionais dos cariús" (: 18), quando dizem "vocês não tem acreano, cearense, paulista? É igual nosso madiha" (:18), pode ser indicativa da percepção de que nós (brasileiros) obedecemos ao mesmo processo de fracionamento. Talvez não seja casual a escolha de exemplos tão diferentes e distantes entre si, já que acreanos, cearenses e paulistas possuem pronúncias muito diferentes ao falarem o português, sua língua é semelhante, mas existem, também, diferenças. Os não indígenas são compostos por pontos de fixação de entidades supra pessoais, da mesma maneira como são os indígenas, o uso das divisões geográficas dos Estados tem relação com o território, tal como entre os próprios madiha, mas, também, é possível que faltem divisões internas nos não indígenas que poderiam sinalizar este processo.

Viveiros de Castro aponta que os Kulina alfabetizados assinam "após seu prenome brasileiro, o nome do madiha, acrescido do sufixo _deni” (1978: 18), como por exemplo, Agnelo Dzumahideni. Na língua kulina ${ }^{227}$, o sufixo_deni, segundo o dicionário de Silva \& Monserrat (1984), indica o plural de substantivos, mas não fica claro se seu uso é restrito aos humanos - um dos exemplos fornecidos é o plural de arco (os arcos - ssissite.deni). De qualquer maneira, é possível que seu uso na tecnonímia

\footnotetext{
${ }^{227}$ O dicionário trata dos dialeto do Igarapé do Anjo.
} 
esteja relacionado com tornar a sua singularidade madiha em uma multiplicidade no contexto de assinar seu nome para os não indígenas, os não madiha por excelência. Um comentário de Altmann parece reforçar essa ideia: "usam também o termo madija acrescido do sufixo deni [...], o que implica a pertença do indivíduo a um grupo de parentes, a uma parentela" (1994: 95).

Não existem muitas informações sobre como os Kulina se referem aos Kulina de outras aldeias. Isto parece não ter interessado os etnógrafos que invariavelmente se focam nas categorias ou grupos (os madiha) em que se dividem os Kulina, sem se aterem à relação entre eles. Um dos únicos indicativos que conseguimos encontrar nesse sentido deve-se a Lorrain que, em uma nota de rodapé, afirma que, na aldeia Terra Nova, os indígenas nomeiam o sibore Madija (madiha do tracajá) da aldeia Piau como Madija ohuaha ${ }^{228}$ e como ladrãodeni ("the thieves") (1994: 132 nota 9). A composição a partir de um substantivo em português, acrescido do sufixo _deni não parece ser problemática. A partir de Terra Nova, os sibore madija seriam aqueles que estabelecem uma relação no modo predação com eles próprios, a relação evidenciando-se pela sua consideração enquanto um coletivo_deni, que provavelmente recusaria essa identidade.

\section{$2.4-$ Bani}

Os Suruwahá, segundo Kroemer, "distinguem o reino animal em três grandes grupos" (1994: 91): os animais que vivem na terra (zamat3m3ru [sic]); os animais e pássaros que vivem nas árvores (egiaty) ${ }^{229} \mathrm{e}$; os seres que vivem na água (aba), onde se incluem peixes, quelônios e jacarés; no entanto, até onde sabemos, não possuem um termo abrangente para animais ${ }^{230}$. Os Jarawara dividem os animais, de forma semelhante aos Suruwahá, em três categorias não nomeadas: "1)aqueles que vivem no chão [...]; 2)aqueles que vivem nas árvores [...]; 3)aqueles que vivem nas águas" (: 47). Eles utilizam o termo bani, que "quer dizer literalmente caça" para animal "em geral,

\footnotetext{
${ }^{228}$ Ohuaha, na grafia de Lorrain, parece ser equivalente ao uvaa em deni. Quando a autora fornece suas terminologias de parentesco ohuaha não aparece como correspondendo a "irmão dele", mas é o que faz a distinção entre os parentes consanguíneos e os consanguíneos colaterais em $\mathrm{G}+1$ e $\mathrm{G}-1$. Em nossa dissertação (Florido 2008), nos guiamos por uma interpretação de ohuaha que agora nos parece equivocada. A noção teria como seu exemplo os irmãos, como já apontaram Townsend \& Adams (1973), representando o menor grau de diferença.

${ }^{229}$ Segundo João Dal Poz (comunicação pessoal), estas diferenças dizem respeito a forma como os animais são mortos. Um animal terrestre, morto por zarabatana também seria egiaty.

${ }^{230}$ O vocabulário de Porta \& Frank (1996) não fornece nenhum termo correspondente a "animal" ou a "animais caçados".
} 
sem especificar qual" (Maizza 2012: 48), bani correspondendo à posição de "presa dos Jarawara".

Para os Paumari, Bonilla apresenta apenas uma distinção dos animais conforme sua posição de presa (igitha) ou predador (tapo'ija). "Em função da posição que ocupam, todos os animais podem ser categorizados em uma das duas categorias exclusivas" (Bonilla 2007: 262). Como a autora aponta, estes termos não são utilizados para definir grupos, mas sim relações; a comestibilidade ou não de um animal pode fazer com que ele seja incluso em uma ou outra dessas categorias, sendo que a criação de um animal o situa como igitha. Não existiriam outras divisões dos animais, mas, dado o lugar menor que a caça desempenha no contexto Paumari em comparação com a pesca e com os povos vizinhos (Bonilla 2007: 266), é possível que as divisões estejam ligadas aos animais da água ${ }^{231}$.

Bonilla argumenta que os subgrupos, comuns entre os arawá, seriam inexistentes entre os Paumari nos dias atuais, embora, alguns viajantes, como Steer e Tastevin, tenham apontado para a possibilidade de sua existência, mencionando "clãs", como o da gente da queixada (Hirari ka Paumari) (2005 :17). Os animais, por sua vez, fariam as vezes dos subgrupos, apresentando a qualidade pamoari, "sua qualidade humana enquanto capacidade de viver em sociedade" (: 20). Um boto chama-se basori, mas quando se quer fazer referência a sua vida em sociedade, antes da sua captura, "fala-se então de 'basori ka-pamoarihi', da sua vida social, em sua aldeia de origem, em referência ao 'povo do boto' ou à "nação do boto"” (: 20). "[T] odos os seres e objetos podem aparecer sob sua forma humana e, assim, os Paumari nunca se surpreendem com a existência de outas 'nações' ou seres" (: 20). Há uma projeção dos subgrupos, numa forma semelhante à madi(ha), para todo o universo e eles mantêm entre si relações de predação, que são concebidas enquanto troca (ou dom) (: 38).

Para os Deni, os animais, de forma geral, compartilham uma identidade, todos são, no limite, bani. Entre eles e também os Kulina, os peixes não participam de forma inequívoca desta classe, sendo agrupados em outra categoria: aba. Pollock afirma que bani, para os Kulina, é carne (meat) e os peixes não são considerados totalmente carne (fully meat - bani) (1985a: 30). Lorrain estabelece a existência de uma oposição entre a

\footnotetext{
${ }^{231}$ Bonilla (2007) afirma que há muitos termos específicos para a pesca e, embora ela os descreva enquanto ações e técnicas, possivelmente eles também correspondam a diferentes objetos de pesca. A caça, por outro lado, é geralmente a busca da caça ('poursuite' du gibier - binaajoikahiki).
} 
carne de caça (meat - bani) e a carne de peixe (the flesh of the fish - aba) (1994: 178). É interessante que, ao contrário dos Paumari, um povo que se volta para as águas, entre os Kulina e Deni, que eram populações da terra firme, os bani possuem um rendimento cosmológico superior aos dos $a b a$.

Diferente do que ocorre entre os Jarawara, bani não corresponde apenas à posição de presa, pois os Deni atribuem à onça o nome bani zavirivi (bani malhado), que seria utilizado antigamente, isto é, quando as onças ainda eram predadores de humanos. Os bani caçáveis são divididos em três classes, de maneira algo semelhante aos Suruwahá. Há os bani nami kude, literalmente os bani originários ${ }^{232}$ da terra, que são os animais terrestres; os bani neme kude, originários do céu, que são os animais que vivem nas árvores, como os macacos; bani aphaharu, os bani que possuem pena/asa, como os pássaros caçados/comestíveis. Há, ainda, animais que podem ou não ser bani, ou podem não o ser o tempo todo, como os aba já mencionados, os anupi (passarinhos, aves de pequeno porte), os pashu abarini (traduzido como "todos os bichos da água"), shunu abarini ("todos os bichos da terra", na qual estão os insetos, os animais que moram embaixo da terra).

Os Deni aplicam o sufixo _deni para aqueles que são madi e aqueles que são kariva, mas nunca o utilizando para os que são bani ${ }^{233}$. Os Deni estabelecem com os madi e os kariva relações predominantemente baseadas na transferência de valores. Com os kariva assumem como base o modo relacional da troca, ao passo que, com os outros madi (indígenas não-Deni), parece haver uma expectativa de que eles ajam no modo da dádiva, o que parece se concretizar quando eles se encontram nas cidades e compartilham com os Deni roupas usadas, refeições, etc.. Aos bani, como já dissemos, a base é o modo predação, sendo possível surgir a guerra, sem a necessidade de transferências durante os ataques.

O único momento, até onde sabemos, em que o sufixo deni é aplicado ao termo bani é quando se narra a história dos Banideni. Esta história é particularmente interessante, pois apresenta os eventos que geraram uma fratura no cosmos, separando madi e bani no nível ontológico. Muitas narrativas tematizam a transformação de

\footnotetext{
${ }^{232} \mathrm{O}$ termo kude indica a origem espacial de algo ou alguém. Alguém vindo do Xeruã (Xeruva) seria considerado Xeruva kude no Cuniuá.

${ }^{233}$ Até onde sabemos, o termo não é utilizado para as queixadas que são também madi. Em uma narrativa em que humanos e animais ainda não estavam diferenciados, há uma referência à aldeia dos Hizamadeni (Queixada deni). Uma pessoa, contudo, afirmou explicitamente que não existem Hizamadeni, que só existe deni de gente.
} 
humanos em animais, mas são sempre partes da humanidade que se transformam, sem problemas para os que permanecem humanos. Os eventos que envolvem os Banideni são diferentes, pois estabelecem as posições de bani e de madi, que poderiam não ser as atuais. A narrativa dos Banideni é muito longa e apenas um dos seus episódios é diretamente relevante, sendo assim apresentaremos um resumo dos eventos sem nos atermos a detalhes.

Banideni $^{234}$

Estavam roubando tabaco do roçado, mas levavam só as folhas grandes. Chamaram dois xamãs, o Pishi Heke e o Shabira Vataka ${ }^{235}$ para descobrir quem estava roubando. Descobriram o rastro dos ladrões e o seguiram. Encontraram um caminho de caça e continuaram até avistarem fumaça no horizonte.

Encontraram um moquém onde estavam sendo moqueados o Tamakuri e o Uruva ${ }^{236}$. Eles estavam bem secos, eram os espíritos deles que estavam sendo assados. Os dois ressuscitaram depois que ralaram suas as costelas (passaram os ossos no ralador). Eles acordaram e achavam que só estavam dormindo.

Combinaram que as pessoas iriam virar vários tipos de formigas para distrair os ladrões. O Tamakuri e o Uruva deviam pular em cima deles e quebrar seus pescoços. Saíram procurando o pessoal do Kapihava ${ }^{237}$, os Banideni, que, quando viram as formigas, foram afastá-las com fogo. As formigas viraram gente de novo e mataram todos.

\footnotetext{
${ }^{234}$ Só obtivemos uma versão dessa narrativa, que parece não ser muito difundida. O episódio final, contudo, nos foi narrado no curso de outras histórias. Na coletânea do Xeruã há uma história que tematiza essa possibilidade da transformação de todos os humanos em bani. Em linhas gerais há muitos episódios semelhantes, mas o protagonista da história no Xeruã é Ukekeni. Este, em uma das narrativas do Cuniuá, é o irmão de Kapihava, o protagonista do mito do Cuniuá em que participam os Banideni. Na outra narrativa de Kapihava, obtida no Cuniuá, ele transforma ativamente as pessoas em animais por elas não terem conseguido impedir que seu irmão virasse caça. Se tivessem conseguido eles não teriam se transformado em caça, mas permanecido gente, enquanto nós viraríamos caça.

${ }^{235}$ Pishi é um tipo de macaco, shabira é um mamífero, Pishi Heke e Shabira Vataka são, provavelmente, xamãs dessas espécies. Não é incomum que os xamãs dos animais tenham nomes próprios conhecidos e que sejam nomeados de forma composta a partir do nome da espécie. Além desses, dois poderíamos citar também o Avi Zuri, o xamã das Antas (avi).

${ }^{236}$ Duas espécies de macaco.

${ }^{237}$ Segundo alguns, Kapihava seria um pássaro, que não tem correspondente no Guia de Aves da Amazônia Brasileira de Tomas Sigrist (2008). Talvez, essa associação decorra do fato dele se transformar em pássaro em outra narrativa de maior difusão, a de Ukekeni e Kapihava.
} 
O Kapihava ficou desconfiado e se escondeu dentro de um buraco em uma árvore grande ${ }^{238}$. Pegaram um pedaço de madeira e tamparam o buraco, prendendo Kapihava. Tentaram derrubar a árvore com o machado, mas Kapihava tinha usado seu poder de xamã e endurecido a madeira, fazendo o machado quebrar. Pensaram em ir pegar o machado do Vasuri ${ }^{239}$, no dia seguinte, porque ele era muito duro. As pessoas perguntaram quem aguentava mais tempo acordado para vigiar a árvore. Estavam lá o Idiku ${ }^{240}$ o Shinama ${ }^{241}$, o Khamanuvi $^{242}$ e o Zapi. O Idiku disse que aguentava 2-3 dias sem dormir, então ficou vigiando.

O Idiku dormiu durante a noite e Kapihava conseguiu escapar. De manhã, cortaram o tronco, mas ele já estava podre. O Kapihava tinha ficado um pouco longe, olhando os acontecimentos. Os madiha comeram o pessoal do Kapihava e depois viraram animais novamente.

[Nesse ponto da narrativa um dos tradutores/comentadores sentiu a necessidade de fazer alguns comentários para esclarecer certas coisas. Ele explicou que as pessoas que comeram os Banideni eram os Tamakurideni, os Uruvadeni $^{243}$. E afirmou que "nós éramos todos bichos (bani) antes".]

O Kapihava recolheu os adornos corporais dos mortos, colocou em um cesto, voltou para sua aldeia e pendurou o cesto dentro de casa. Duas crianças foram ver o que era e reconheceram os enfeites de sua mãe. Perguntaram para o Kapihava quem tinha matado a mãe deles e foram informados de que tinham sido as pessoas do outro lado do igarapé. Eles tinham comido a mãe das crianças porque eles comiam bani $\left(\right.$ caça $\left.^{244}\right)$.

\footnotetext{
${ }^{238}$ Há aqui referência a ele ter levado duas crianças consigo, mas não é muito claro se elas ficaram vivas ou foram mortas. Elas podem ser as duas crianças que aparecem na sequência.

${ }^{239}$ Uma espécie de pássaro.

${ }^{240}$ Mutum, uma espécie de ave.

${ }^{241}$ Cutia.

242 Paca.

${ }^{243}$ A questão de singularidade e multiplicidade da seção anterior. Salvaram um tamakuri e um uruva, que na hora de se relacionarem com os inimigos já se tornaram múltiplos.

${ }^{244}$ É possível que haja aqui uma diferenciação entre as pessoas que comem bani, a carne, e as pessoas que comem os espíritos dos animais. As duas crianças vão, posteriormente, caçar os bani abanuni (alma do bani). Isso é algo que se mantém até hoje. Da perspectiva Deni, os humanos comem a carne dos animais e o espírito destes vai embora morrer em suas aldeias; já os animais podem vir a comer o espírito dos humanos longe dos seus corpos que eventualmente morrem na aldeia.
} 
As duas crianças foram pelo caminho e se transformaram em adultos. Chegando à aldeia dos Baniabanuni ${ }^{245}$, voltaram a ser crianças. Eles saíram procurando pelos filhos dos Baniabanuni e pegaram a alma do filho do $\operatorname{Sura}^{246} \mathrm{e}$ do filho do Zuvihi ${ }^{247}$. Eles morreram. O Zaziu ${ }^{248}$, xamã, tentou curar, mas não conseguiu, estavam mortos mesmo. As duas crianças foram novamente e levaram as almas do filho do $\mathrm{Manu}^{249}$ e do Humu ${ }^{250}$. Fizeram isso várias vezes.

Um dia, as duas crianças falaram para o seu avô Kapihava que as caças estavam gordas. Pediram para ele fazer zarabatana. A partir de partes do seu corpo, Kapihava inventou a zarabatana, os dardos, os ingredientes do veneno de caça (iha) e ensinou para seus netos o modo de preparo.

Alguns dias depois, o Kapihava saiu para testar o veneno. Ele assoprou e matou um maphi ${ }^{251}$ e um duphiphi ${ }^{252}$. Como ele conseguiu matar estes dois passarinhos, Kapihava e os seus se transformaram em animais, mas se ele tivesse errado, seríamos nós que teríamos nos transformado em caça.

O Kapihava inventou a árvore de sorva e as duas crianças foram até a aldeia dos bani levando duas frutas. Elas se passaram pelos filhos dos Baniabanuni que haviam levado e convenceram as pessoas a irem até a árvore pegar os frutos. Só o $\mathrm{Zau}^{253}$ ficou desconfiado. As pessoas foram até o pé de sorva e havia muitas frutas pelo chão e nos galhos. Os bani subiram na árvore $\mathrm{e}$ os dois rapazes foram matando todos com suas zarabatanas.

O Zau havia escondido os filhos do Humu, Shura, Tamakuri e Zuvihi. Ele se balançou num pé de açaí e parou do outro lado do rio, por isso lá tem muita caça.

\footnotetext{
${ }^{245}$ Baniabanuni seria Bani + abanu (alma/espirito) + $n i$ (marcação de gênero feminino).

${ }^{246}$ Espécie de macaco.

${ }^{247}$ Espécie de macaco.

${ }^{248}$ Espécie de macaco.

${ }^{249}$ Espécie de macaco.

${ }^{250}$ Espécie de macaco.

${ }^{251}$ Não é uma pessoa e sim um pássaro dessa espécie. Houve a identificação de uma série de passarinhos do gênero Pipra como sendo dessa espécie. São animais pequenos que variam entre $8-13 \mathrm{~cm}$ (Sigrist 2008). Segundo o Wiki Aves "É um pássaro que se locomove super rápido" (grifo nosso) (http://www.wikiaves.com.br/pipra em 29/03/2013).

${ }^{252}$ Um passarinho, o beija-flor, que também se caracteriza pela grande velocidade durante o voo.

253 Preguiça.
} 
Esta narrativa estabelece que a posição de bani era indefinida anteriormente. Os macacos, as aves e demais bani caçavam os humanos como se estes fossem os bani. O pano de fundo é o de que tanto humanos quanto bani possuem uma cultura em comum (Viveiros de Castro 2002). Os animais plantam roçados, possuem xamãs, consomem rapé ${ }^{254}$, caçam e comem a carne assada. Inicialmente, se estabelece uma relação no modo predação, sinalizada duplamente, pelo roubo do roçado e pela morte de dois $\operatorname{macacos}^{255}$ que são moqueados.

Os macacos ressuscitados acabam se juntando aos seus parentes para atacar os humanos. Nesse ponto, os humanos passam a ser as vítimas, objeto da predação, pois são comidos após serem mortos. A forma de matar, contudo, é diferente: os macacos quebram os pescoços, se engajam em combate corporal com sua presa. A partir do momento em que os humanos desenvolvem a técnica de caça com zarabatana eles se estabilizam como gente e forçam os animais a serem a caça, ou seja, na versão que apresentamos, é no momento em que o veneno e a técnica funcionam de forma apropriada que há a fixação das perspectivas. Não sem razão, são pássaros pequenos e velozes $^{256}$ que Kapihava caça, ele se mostra um caçador ideal, dominando a perspectiva do predador e não a da presa.

O final da narrativa é marcado pela matança dos animais, não como em uma simples caça, mas em uma tentativa de extermínio. A versão do Xeruã situa nesse momento a não transformação de todos em animais. O protagonista pontua: "Matei todos os macacos, e eles viraram macacos mesmo" (Sass 2004: 59). Na disputa pela perspectiva, é a guerra que vai garantir aos humanos seu lugar no cosmos, eles são os predadores, enquanto os animais são as presas. Como já havíamos dito inicialmente, com os animais a relação é a guerra, mas a predação ocorre nas duas direções, sendo necessário garantir, ativamente, que os animais sejam as vítimas. A manutenção da perspectiva dos Deni como matadores e agressivos faz com que eles sejam vítimas, apenas, dos xamãs animais e não de todos eles.

Na narrativa, as pessoas madiha comem o corpo dos bani, já os bani comem a alma (abanu) das pessoas. Essa diferença é interessante, pois, como aponta Azevedo (2012), quando querem ter filhos, os Deni pedem para o xamã implantar uma alma

\footnotetext{
${ }^{254}$ O rapé é fundamental para os Deni, estando presente tanto no xamanismo quando na vida cotidiana. ${ }^{255}$ A versão do Xeruã apresenta também as duas predações iniciais: a do tabaco e a de pessoas/animais. ${ }^{256}$ As pessoas colocam o beija flor como pássaro comestível, mas acentuam a dificuldade de o matarem.
} 
(abanu) no corpo da mulher, alma que não é necessariamente nova, podendo ser a de um parente já falecido ou a de um animal. As relações que os humanos estabelecem com outros seres do cosmos são, assim, de dois tipos: um deles, realizado pelo caçador, visa obter o corpo (caça) e resulta na morte dos Outros; outro, realizado pelo xamã, visa obter a alma (abanu), com o objetivo de fornecer um corpo para ela, um corpo humano, de parente.

Embora pareça que os Deni, atualmente, não vejam como obrigatória a intervenção xamânica para a procriação, há muitos casos de pessoas que se originam da alma de animais implantadas em suas mães. As pessoas são, assim, bani.abanu(ni), espíritos de animais, que é a parte capturada na predação originária dos animais. Na história de Kapihava, o seu pessoal é inicialmente Banideni, isto é, seus corpos são os da caça. As duas crianças saem para caçar os Baniabanuni ${ }^{257}$, que são almas de bani, tal como inicialmente eles estavam moqueando o espírito dos macacos. Ao fazer a guerra, os humanos garantem seu lugar na caça, isto é, que sejam eles que passem a comer a carne.

É interessante que, entre os Deni, parece haver uma inversão da lógica que Dal Poz (1993) apresenta para os Cinta-Larga. Entre estes, a guerra de extermínio aos animais resultou na transformação das pessoas em animais, permutando-se em caçada. Nesse contexto, em que os conflitos se associam com o canibalismo, a guerra é, de certa forma, uma caçada, situada no modo relacional da predação. Entre os Deni, não há canibalismo na guerra, esta procura, antes, obliviar a diferença do que consumi-la e incorporá-la. A caça inicial, isto é, a predação, que fluía nas duas direções, transmuta-se em guerra para que os humanos não se transformem em animais.

A questão parece ser que havia uma indistinção inicial entre animais e humanos, pois seus agrupamentos eram semelhantes e as relações entre eles se alternavam. De forma semelhante aos Tupinambá (Carneiro da Cunha \& Viveiros de Castro 1986), no tempo dos Banideni, aqueles que assumem a posição de inimigos (de caça) vão sendo alternados na temporalidade: hora os humanos matam e consomem os bani, hora os bani matam e consomem os humanos. Diferente de como ocorre entre os Tupinambá, para os quais a vingança não tem início e nem fim, o mito Deni marca um início e uma desproporção: é o roubo de tabaco que motiva a primeira agressão e, mesmo que dois

\footnotetext{
${ }^{257}$ Bani é um termo feminino, dai a marcação do gênero feminino pelo uso do sufixo _ni, acrescida ao termo abanu.
} 
macacos tenham sido mortos, eles são ressuscitados; logo, não são suas mortes a causa da vingança.

Há uma escalada da violência, a partir de um ato de predação de tabaco, pois. inicialmente, dois macacos mortos revivem; depois todo o pessoal do Kapihava morre definitivamente; em seguida, são os filhos dos bani que não são ressuscitados, mas ao invés de ocorrer uma vingança dos bani, há o seu extermínio pelos netos de Kapihava. Após os humanos se garantirem enquanto caçadores, o que ocorre, depois, da morte dos filhos dos macacos, há um aumento da violência, não uma inversão perspectiva. Entre os Tupinambá, em que guerra e caçada possuem algo de semelhante, a vingança é um motor da temporalidade, a inversão de perspectiva é o ponto; entre os Deni, não canibais, a guerra procura a aniquilação, isto é, evitar novos ataques que demandariam novas vinganças. Não é um processo reversível no tempo, mas um em que se procura estabelecer e reforçar uma perspectiva, a de predador e não de presa $^{258}$, num movimento iniciado no tempo dos Banideni e que permanece ativo nos dias atuais.

Se havia, de fato, uma indistinção inicial e, como dissemos, há recortes madi em múltiplos níveis na humanidade num processo que tem como limite máximo a oposição dos madi com os kariva e os bani, era de se esperar que o mesmo ocorresse entre os bani. Como já foi dito, o status de bani para algumas espécies é incerto, talvez em uma oposição aos madi, os peixes e insetos seriam bani, mas tal oposição não parece ter relevância. O cosmos é, contudo, povoado por diversas entidades que correspondem a diferentes espécies de animais, insetos, etc. Há, por exemplo, anupi (passarinhos pequenos), avani (cabas/marimbondos/vespas), hizi (abelhas), que se diferenciam em espécies nomeadas, às vezes com termos que não utilizam a identidade maior, como dii que é um tipo de avani.

Os peixes são cosmologicamente relevantes no contexto em que os animais aquáticos (entre os quais se inclui a Cobra Grande) formam uma aldeia para onde vão os espíritos de alguns mortos, mas isto só ocorre quando o foco recai sobre sua humanidade. Pelo que pudemos observar diretamente nos rituais, seu único papel é o de servir de alimentação, isto é, comparecem enquanto corpos sem agência (comida), pois suas almas não estão presentes. Não parecem existir rituais em que os personagens

\footnotetext{
${ }^{258} \mathrm{E}$ como veremos no próximo capítulo os animais representam um risco predador principalmente para as crianças pequenas, isto é, aqueles ainda não totalmente estabelecidos enquanto humanos, enquanto os predadores.
} 
sejam os peixes, como acontece com as aves e mamíferos que estão, invariavelmente, presentes.

A partir do ponto em que bani opera como identidade dos animais caçáveis/comestíveis, há a divisão anteriormente mencionada entre animais da terra, das árvores e com asas, baseada na associação com seus locais de moradia. Nesse nível, é difícil imaginar como os animais poderiam assumir uma singularidade, já que o próprio dono dos bani (Zanikuva, o jabuti gigante) trás em si todos os animais: as caças em um continente e os predadores em outro. A figura dos donos não apresenta de forma clara a replicação, pois eles, geralmente, diferem das entidades que contêm. Bithamadi (a gente do pium) contém em si não apenas piuns, mas, também, mosquitos e mutucas, ou seja, a gente do pium é composta pelos insetos alados e hematófagos ${ }^{259}$.

Os donos não parecem ser uma figura muito explorada na cosmologia Deni, geralmente internalizando diferenças mais do que semelhanças, sua figura não atua no nível das entidades supra pessoais. O próprio xamã, que parece manter uma relação de dono/controlador com seus espíritos, os coloca na barriga após transformá-los em katuhe (pedra-feitiço). Talvez, o ponto seja que não há, de fato, relação entre a identidade singular exterior (o Um para os Outros) e a multiplicidade replicada interiormente (o conjunto dos iguais a Um), pois a entidade singular só existe sob a condição de os elementos interiores não se relacionarem. Se a semelhança interna é o que define uma unidade para exterior, ela é composta por uma multiplicação dela mesmo em seu interior, não sendo possível que exterior e interior se relacionem, pois, para isso, haveria a necessidade de uma diferença.

A identidade singular dos animais e sua replicação interna surgem de forma clara quando o foco recai sobre as espécies. Nas narrativas, é recorrente a presença de animais enquanto humanos, porém não se tratam de vários animais que são humanos e sim da espécie enquanto agente, como sujeito. Quando Avi (o Anta), ou Zanikuva (o Jabuti), ou Tamakuri (o Macaco) aparecem, eles não são um membro da espécie, ele são o próprio coletivo personificado, são uma entidade. Não se trata de uma anta, nunca há um de muitos possíveis agentes, o que se expressa nas narrativas é a Anta como agente

\footnotetext{
${ }^{259}$ Na versão do Xeruã (Sass 2004) o monstro dessa narrativa não é nomeado como Bithamadi e sim Shushuvaha Shushu, contendo em si insetos alados e com ferrão, incluindo também cabas (marimbondos/vespas) e abelhas, não apenas os hematófagos.
} 
(sujeito), ou as antas como paciente, ou seja, aquele que faz a ação é sempre uma singularidade, aquele que sofre pode ser uma multiplicidade.

Assim como os madi, que se contrapõem aos kariva e bani, se dividem em entidades como Deni, Apurinã, Paumari, Kulina, etc., ou seja, contêm tipos que se relacionam, os bani, alvo da guerra e/ou predação dos madi, se compõem a partir de determinadas espécies diferentes quando considerados internamente. Tais como os Deni, por sua vez, se dividem nos subgrupos, as espécies animais apresentam subdivisões internas, isto é, tornam-se uma multiplicidade de entidades que não correspondem simplesmente aos exemplares da espécie. Entre a espécie enquanto algo semelhante a um grupo étnico e os seus membros individuais, há entidades intermediárias. Todos os animais são replicações do Animal, porém há subgrupos de animais que diferem entre si, embora todos sejam Animal.

Só sabemos de duas espécies de animais que são divididas dessa forma, embora possa haver outras que raramente são mencionadas, ao menos em conversas com o antropólogo. Os xamãs conseguem identificar três tipos de queixadas (hizama) e alguns tipos de anta (avi) e, embora apenas eles possam fazer a identificação segura, as pessoas comuns são capazes de perceber alguns dos diferentes tipos. As queixadas podem ser hizama vara $^{260}$, que são valentes ${ }^{261}$ e em pequeno número; hizama uzaputahari bunu (queixada da fruta de caraná grande); ou hizama zami bununi (queixada da fruta de paixuba), da qual existem muitos exemplares. Dois dos tipos de queixadas possuem identidades formadas com base em frutas não cultivadas, mas cujas plantas são usadas na confecção das casas (uza) humanas. O processo, aqui, é semelhante ao que se estabelece entre os humanos, cujas entidades coletivas intra-madi se baseiam em elementos do mundo natural.

As antas (avi) apresentam uma variação maior de tipos, sendo que o pertencimento de cada animal abatido a um é estabelecido pelo xamã. Todas as antas são avi, mas cada uma delas possui outra identidade: shami bani, shihiri bani, shipari veshe bani, shipari putaharu bani, biha bani, kavazu bani ${ }^{262}$, etc. A nomenclatura é

\footnotetext{
${ }^{260}$ Um dos informantes disse que só a vara era diferente, as outras duas seriam iguais. É possível que apenas os hizama vara sejam facilmente identificados pelos não xamã e o termo não indique propriamente um tipo de queixada e sim uma disposição.

${ }^{261}$ Elas atacam os seus atacantes invés de fugirem.

${ }^{262}$ Essas designações foram as primeiras com que tivemos contatos, no contexto da descrição da viagem de um xamã até a aldeia das antas.
} 
composta a partir de um termo que designa uma das plantas cultivadas ${ }^{263}$ mais o sufixo bani. Os humanos comuns só podem perceber, até onde sabemos, quando a anta abatida é do tipo shipari putaharu bani, uma anta da banana comprida, um dos alimentos mais saborosos do roçado ${ }^{264}$, assim como a carne desta anta é mais saborosa que as demais.

Cada tipo de anta é responsável pelo cultivo do vegetal que fornece a sua identidade e, quando há uma festa, cada qual leva seu alimento preparado para que os outros possam consumi-lo. A divisão dos bani apresenta certa afinidade com a noção de especialização de funções, afinal, cada um é responsável pela produção de um alimento diferente. A diferença, contudo, não é uma simples organização, ou apenas a extensão de algo humano (as divisões madi) para as antas, que são os animais com quem os Deni trocam comumente de perspectiva (cobra-anta ${ }^{265}$ ). A diferença está no corpo, tanto que é possível perceber no paladar um dos tipos de anta, daí existir uma diferença de ponto de vista entre elas.

Um exemplar da espécie não é necessariamente igual a outro, cada um possui uma perspectiva diferenciada, mesmo que elas sejam muito semelhantes nesse nível. Tal como os Havadeni e os Minudeni, divisão intermediária entre a pessoa madiha e o Deni madi, que não apreendiam as mesmas larvas da madeira como $a p u$, as antas são todas agricultoras e veem diferentes plantas cultivadas como comida. Todos participam de um mesmo e único processo cosmológico, em que cada um dos termos em determinada oposição se replica internamente numa multiplicidade deles mesmos, mas que podem se singularizar quando não estão em oposição, isto é, quando o foco recai sobre sua semelhança, apesar das diferenças.

\footnotetext{
${ }^{263}$ Nas investigações posteriores obtivemos outras possibilidades, quase sempre composta a partir das plantas cultivadas. As exceções seriam siru bani, uma fruta não cultivada, e mapuvatuvehinade avi, que em realidade seria uma anta em um estado específico e não uma categoria coletiva, indica uma anta ainda pequena, ou com filho pequeno.

${ }^{264}$ E também um alimento que é o centro da grande cerimonia inter-aldeã: banivadanaha.

${ }^{265}$ Cobras:humanos::humanos:antas::perspectiva cobra:perspectiva anta.
} 


\section{Capítulo 3 - Relações, aliança e termos.}

Este capítulo está dividido em duas partes: a primeira apresentam as ideias Deni sobre casamento e proibição do incesto; a segunda se detém sobre as relações, tais como concebidas pelos Deni, e seus termos. As considerações tecidas neste momento devem ser levadas em conta durante a leitura do próximo capítulo, pois, aqui, tratamos dos modelos Deni sobre seu próprio parentesco, sejam conscientes ou inconscientes, no próximo verificamos o resultado empírico de sua aplicação. Poderíamos dizer que abordamos, mas não apenas eles, os níveis terminológico (ou categorial) e normativo (ou jural - Needham 1973) do parentesco, sendo o prático (ou comportamental) focado no próximo capítulo.

Primeiro, consideramos a questão da aliança matrimonial, porque esta possui uma relação direta com alguns elementos do cosmos, figurando como uma espécie de transição entre o que abordamos até o momento e um foco que se fechará sobre o parentesco. Teremos que descrever alguns aspectos ligados à sexualidade, pois são fundamentais para entender os casamentos. Também, serão feitas algumas considerações quanto à concepção, na medida em que forem relevantes para entender como a pessoa é construída (Da Matta \& Seeger \& Viveiros de Castro 1979). Na sequência, serão apresentadas algumas formas de relações interpessoais concebidas pelos Deni e descreveremos os vínculos que se estabelecem pela nominação, pelo parentesco e, por último, alguns que partem do parentesco e o extrapolam. Discutiremos certas categorias relacionais que são importantes no pensamento sociológico Deni, utilizadas para pensar e organizar o cosmos.

Algumas das relações nomeadas formam uma espécie de sistema, sendo dimensionadas e utilizadas em função umas das outras. Estas, que se materializam na terminologia de parentesco, são aplicadas, neste contexto etnográfico específico, de forma a abarcar todo e cada um dos humanos. Para determinada pessoa, todos os outros humanos são, necessariamente, incluídos em uma, e apenas uma, delas, mesmo que não o sejam de forma imutável. Não sem razão, a regulamentação da vida sexual é expressa utilizando estes e não outros termos. Muitas das outras relações só ocorrem entre pessoas que mantinham determinado vínculo anterior e não participam de um sistema, isto é, não correspondem a ligações interpessoais opostas a outras de qualquer outro tipo. 
Embora chamemos de termos de parentesco, nem todos que recebem uma denominação são considerados parentes $\left(u v i b u v a^{266}\right)$, mas todos possuem a capacidade de poderem, no limite, se tornar parentes. Os não humanos são, primordialmente, aqueles que não podem vir a ser parentes e que, portanto, não recebem termos de parentesco. Isto seria condizente com a visão de que na Amazônia o processo de parentesco é o processo de despotencialização da afinidade (Viveiros de Castro 2002). São as relações de afinidade o que se estende aos (potencialmente) humanos que não são parentes, mas que podem vir a ser tornar, ter sua afinidade removida.

\subsection{Casamento}

O casamento, entre os Deni, pode ser pensado como tendo um duplo aspecto, por um lado, é uma relação que se estabelece entre um homem, uma mulher e seus filhos (não necessariamente de ambos); por outro, é um acontecimento que envolve as famílias dos cônjuges, podendo, mesmo, tornar-se algo que preocupa e envolve toda a aldeia. As relações (sexuais e matrimoniais) entre homens e mulheres parecem ser um ponto em que é possível aproximar a politica cósmica e a vida cotidiana, pois, sob a ótica do casal, suas ações vão ter impacto no cosmos e os submeter aos seus perigos, enquanto que para a comunidade, elas se relacionam com a convivialidade (Overing \& Passes 2000). Por um lado, temos a relação com forças e entidades do cosmos que representam perigo para os parentes, de outro, as disputas e conflitos que podem surgir e são um risco para a aldeia, dado os sentimentos negativos que podem despertar.

O casamento, para os Deni, em sua relação com o cosmos e o devir, é uma relação odorífica. O dicionário de Koop \& Koop (1985) fornece: “mahu_ha (v. intr.) casar-se (sujeito singular)" e "mahu_keri (v. intr..) casar-se, moço e moça (sujeito plural)" (1985: 70). Infelizmente, não podemos fazer uma etimologia do verbo mahu_keri, pois desconhecemos o significado da partícula_keri. A forma mahu_ha pode ser analisada detalhadamente a partir da consideração das maneiras como é empregada.

A nosso ver, mahu_ha é composto por dois elementos, mahu, comumente um adjetivo, e o verbo _ha. O dicionário de Koop \& Koop fornece: “非 $\boldsymbol{m a h u}$ (adj.) cheiroso (cheiro bom ou mau)." (1985: 70) e “ _ha (v. intr., tr.) ser, estar, haver, ter possuir" (: 55). Uma pessoa casada é referida como mahu.tu.ha.de (mahu + tu [3 $3^{\mathrm{a}}$. pess.

\footnotetext{
${ }^{266}$ Veja capítulo 1 e 2.

${ }^{267}$ \# indica que o verbo pode ser usado sem um substantivo ou pronome associado.
} 
sing.] + ha + de [adjetivador]), que traduziríamos por "ela está cheirando". Que a partícula $h a$ corresponda ao verbo _ha, e não a uma parte do verbo, fica evidente em outros usos da ideia de casamento. Um homem pode convidar uma moça para casar com ele pelo uso da frase mahu.i.nina ${ }^{268}$ na qual não está presente o verbo _ha, pois não indica um estado constituído, sendo algo como "vamos cheirar", um futuro. Para mandar um rapaz casar com uma mulher diz-se: mahu.ti.kha.ha (mahu $+t i\left[2^{\mathrm{a}}\right.$ pess. sing.] + kha [“(suf. v., term. v.) modo imperativo (sugestão)” Koop \& Koop 1985:67] + $h a^{269}$ [“(suf. v., term. v.) aspecto distributivo, masc.)" :55], algo como "compartilhe seu cheiro!". Por fim, quando perguntam se uma pessoa casou (mahu.ti.ha.ru ${ }^{270}$ ), as duas respostas possíveis são compostas pelo uso do verbo _ha: se não tiver casado responde kahude.u.ha.ru (kahude [solteiro] $+u$ [1 $1^{\mathrm{a}}$ pess. sing.] + ha (verbo ser, estar) $+r u$ (terminação verbal) ou mahu.u.ha.ru se casou.

O casamento pode ser entendido como um compartilhar de cheiros em que marido e mulher compartilham algo de si um com o outro. É interessante notar que, o casamento na visão Deni se assenta na leitura do Ensaio sobre a Dádiva de e Mauss feita por Gregory, quando este afirma que "a troca de dádivas [gift exchange] é uma troca de coisas inalienáveis ${ }^{271}$ entre pessoas que estão em um estado de dependência recíproca" (1982: 19), que, como aponta Viveiros de Castro, é, também, uma definição do parentesco. Isto é evidente para a dimensão afinal, a aliança se funda na troca matrimonial, mas, também, pode ser aplicado a filiativa, "concebida enquanto processo de transmissão de coisas inalienáveis - partes do corpo e substancia, classicamente, mas também memórias, narrativas [...] - que criam pessoas que deste modo originam-se em um estado de dependência reciproca." (2009: 246).

Isto concorda com tudo que dissemos anteriormente sobre o compartilhamento/transferência de uma perspectiva entre pai e filho e, como veremos no próximo capítulo, pode ser, também, transmitindo um ponto de vista a partir do qual são concebidas as relações com algumas mulheres. Para os Deni, as pessoas são formadas pelo sêmen de seus pais, ou seja, seus corpos são compostos por partes do

\footnotetext{
${ }^{268}$ A partícula $i$ corresponde ao pronome pessoal de $1^{a}$ pessoa plural: "nós". A terminação nina é usada quando se convida alguém para alguma atividade. Por exemplo, aba.huka.i.nina (Vamos pescar?), hiri.i.nina (Vamos cantar?). O mais comum, entretanto, parece ser a forma mahi.i.keri.na.

${ }^{269}$ A partícula ha aqui não corresponde ao verbo, pois em Deni todo verbo demanda uma sufixo de terminação verbal.

${ }^{270}$ Também há a forma mahutikaharu.

${ }^{271}$ Nota nossa. Gregory (1982:18) mostra que a inalienabilidade das dádivas é algo recorrente em Mauss e é esta a diferença principal em relação à troca de mercadorias.
} 
corpo destes. O cheiro associado a esta secreção é, possivelmente, o cheiro que vai ser compartilhado quando os filhos tiverem relações sexuais com outras pessoas.

A questão do cheio é fundamental para entender o casamento Deni, sendo um elemento essencial da cosmologia. O cheiro está relacionado aos fluídos corporais, o odor do casamento é associado às repetidas relações sexuais do casal, atividade que, de modo geral, faz com que o aroma de um passe a ser discernível no outro. Todo ato sexual leva a uma troca de $\operatorname{cheiros}^{272}$, porém, isto parece não trazer maiores consequências se for algo casual e episódico. Este é um dado perceptível pela observação das práticas, mas não nos discursos, que apontam consequências em função de uma única troca de cheiros entre homens e mulheres que não deveriam fazê-lo.

A importância do cheiro não se limita apenas a isto, sendo relevante em muitas facetas do cosmos Deni: atraem os animais que atacam mulheres menstruadas quando se banham dentro do rio ou igarapé, que levam as almas das crianças pequenas, etc.. Quando uma mulher casada tem relações sexuais com seu amante e prepara a comida do marido, isto faz com que este adoeça, pegue um "tumor" $\left(m u h u^{273}\right)$. Alguém que saiba do ocorrido pode alertar o marido dizendo: tipanadi zapani mahuni, onde tipanadi - sua esposa, zapani - mão dela, mahuni - "(s2g) termo genérico: cheiro, fedor” (Koop \& Koop 1985: 71), algo como "a mão de sua esposa está com cheiro ruim”. O adultério faz com que o marido entre em contato com cheiros que não deveria, o que é negativo para ele, é imadipei.

\section{Imadipei}

Os Deni associam alguns comportamentos com imadipei, termo que traduzem por "faz mal" e o Dicionário de Koop \& Koop fornece: "imadipe'i' ${ }^{274}$ (adj.) perigoso; que traz o mal” (1985: 60). Há uma gama de ações associadas a ele, desde atirar sementes de frutas nas pessoas ${ }^{275}$, ou pegar frutas venenosas, até ter comportamentos inadequados com os "irmãos" e "irmãs", como fazer brincadeiras de cunho sexual com

\footnotetext{
${ }^{272}$ Uma das formas dos homens brincarem entre si consiste em um deles fungar o nariz algumas vezes, após a chegada de outro que estava em uma caçada ou no roçado. O que realiza a brincadeira faz, então, comentários sugerindo estar sentido o cheiro de uma determinada moça com quem o outro teria feito sexo antes de se juntar ao grupo.

${ }^{273}$ É uma infecção, durante a qual o pus se acumula embaixo da pele e causa muita dor.

${ }^{274} \mathrm{O}_{-}^{\prime}$ indica oclusão glotal.

275 Não temos ideia de porque isto faria mal. As frutas estão originalmente presentes no céu, sendo que aparecem nas árvores quando algum xamã viaja para o céu e as derruba das árvores do céu.
} 
eles, etc.. Os comportamentos são tão variados que é difícil encontrar algum substrato comum entre todos eles.

De modo geral, não há uma definição clara do que é este mal, ou, pelo menos, não é algo que se formula claramente para o antropólogo. Pela nossa observação em campo, o termo é, frequentemente, utilizado quando as crianças fazem algo que não deveriam, nesta hora dizem: imadipei $\operatorname{sese}^{276}$. Talvez esteja ai sua origem e indeterminação, a associação com algo negativo, que não demanda definição precisa, mas que deve ser evitado. Um mal inespecífico pode surgir no caso de ocorrer algo que não deveria acontecer, porém, muitas vezes, a negatividade da ação é estabelecida após o ocorrido, ou seja, depois do comportamento indicam que é imadipei, visando impedir a sua repetição e não a sua anulação.

Talvez, imadipei seja, de fato, um problema de linguagem, pois, seria tentador ver o termo como sendo na verdade uma expressão: ima dipei. Ima, como já mostramos no capítulo 1, se refere à palavra, a fala, a mensagem, a um conteúdo comunicativo oral (quando escrito a forma é ima hanude - “hanu [v. tr.] escrever, desenhar” Koop \& Koop 1985: 56 + _de adjetivador). Dipei, na tradução do dicionário de Koop \& Koop, é “\#dipe'i (adj.) feio (aparência)” (1985:53). A expressão seria algo como "mensagem feia", ou seja, remeteria a um problema de estética ${ }^{277}$ e a todo o perigo que decorre disto.

Há toda uma preocupação estética no cotidiano Deni, sendo dada especial atenção às crianças que, principalmente para os primeiros filhos, são enfeitadas e pintadas frequentemente. Os pais têm grande preocupação com que os filhos cresçam fortes e saudáveis e, mesmo que não seja algo trabalhado diariamente, a aparência nunca é totalmente descuidada, sendo a ornamentação corporal infantil muito elaborada nos dias em que ocorrem imaamushinaha ${ }^{278}$, as festas/rituais. Este é um momento em que há um grande investimento para que os infantes cresçam (Florido 2013), estando a necessidade das pessoas (para as jovens é quase obrigatória) se tornarem belas durante estes eventos associada com a animação que acelera o crescimento infantil.

\footnotetext{
${ }^{276}$ Sese é um termo intraduzível, sendo que muitas vezes ele é usado sem o imadipei.

277 A importância da dimensão estética para as populações ameríndias já está bem estabelecida pela antropologia e não caberia uma discussão pormenorizada aqui. Para um panorama veja, por exemplo, a coletânea organizada por Vidal (1992) inteiramente dedicada ao tema e cujos artigos apresentam a importância da dimensão estética em diversos contextos.

${ }^{278}$ Veja capítulo 1.
} 
Podemos traçar um paralelo interessante entre o imaamushinaha e o imadipei e a cura estética Shipibo-Conibo, população da família linguística pano localizada na Amazônia peruana, na região do rio Ucayali. Como aponta Gebhart-Sayer, "a terapia Shipibo-Conibo é essencialmente uma visão de desenhos ideais (quer dizer, não materializados), que são aplicados ao corpo do paciente" (tradução nossa - 1986: 192). Durante uma visão ligada ao consumo de ayahuasca, o xamã entra em contato com figuras caóticas que ele organiza de forma a transformá-las em coisas belas, organizadas, sendo a própria sessão de cura um evento visual, olfativo e sonoro no qual a estética está em primeiro plano. Os desenhos cantados, ou cantos desenhados, aplicados no doente são destruídos, apenas, quando ocorre novamente uma doença, sendo que a pele da Cobra Grande é a fonte de todos os desenhos e cores imagináveis.

No contexto Deni, imadipei seria uma perturbação estética com consequências cosmológicas, podendo ser entendido o imaamushinaha como um dos momentos em que há o restabelecimento estético da ordem cosmológica. Temos duas traduções para o termo imaamushinaha: uma do dicionário de Koop \& Koop, que o traduz simplesmente por "(s.f.) festa" (como fazem os próprios Deni); e a que se deve a Kroemer, para quem o significado é "prolongação da boa conversa" (1997: 95). A nosso ver, o termo seria em realidade uma expressão cujo significado preciso nos escapa, mas que seria decomposta em ima amushi.naha. Aqui ${ }^{279}$, amushi funciona como verbo e seu sentido corresponde ao fornecido por Koop \& Koop: “1 (v.intr.) estar bom, bonito, limpo, liso, funcionando, delicioso" (1985: 46). As partículas na e ha poderiam corresponder a um verbo auxiliar (“_na (v. intr.) verbo auxiliar: ser; estar; fazer; dizer” Koop \& Koop 1985: 74) e uma terminação verbal que indica aspecto distributivo.

De qualquer modo, os imaamushinaha seriam a forma de trabalhar a estética da convivialidade (Overing \& Passes 2000), na qual os cantos e as demais atividades asseguram que o belo se mantenha e se restabeleça. Isto tornaria inteligível porque a memória dos adultos é marcada pela realização de grandes imaamushinaha (imaamushinaha banivadanaha) na época em que todos os Deni (segundo eles) passaram a morar juntos, época em que se construiu e consolidou a noção de Deni enquanto uma realidade (um povo). É nisto que reside a semelhança Deni com as curas Shipibo-Conibo, em ambos a estética (re)cria o bom e o belo através de um processo em que múltiplas dimensões participam, sendo que, para os últimos, os desenhos cantados,

${ }^{279}$ Amushi está presente em muitas expressões. Ele também funciona como adverbio. 
que devem ser decodificados, têm sua origem na pele da Cobra Grande, enquanto que, para os Deni, foi ela quem ensinou diretamente a forma correta dos cantos do imaamushinaha verdadeiro.

Verdadeiro segundo os próprios Deni, para quem os imaamushinaha cotidianos, que envolvem invariavelmente partidas de futebol e forró noturno e ocorrem nos aniversários (quase obrigatórios quando as crianças completam um ano), são diferentes, são imaamushinaha bedeni (pequenos), mesmo que carreguem a mesma importância do ponto de vista estético. Possivelmente, os imaamushinaha eram realizados de forma a cancelar os imadipei, um processo que encontrou seu ápice na história recente de fusão das aldeias, mas, atualmente, eles parecem não ter uma relação direta. A transformação deste processo ocorreu tanto por uma mudança no conteúdo dos imaamushinaha, que agora se pauta pela estética do kariva ${ }^{280}$, quanto do imadipei, que, em alguns casos, passou a causar um mal especificado e irreversível.

Alguns comportamentos que seriam caracterizados como imadipei são atualmente associados à outra noção: khema. Os Deni traduzem o termo por "pecado" e não existe verbete correspondente no dicionário de Koop \& Koop (1985), estando seu uso associado aos imadipei que possuem uma conotação sexual, sejam as brincadeiras inapropriadas ou as relações sexuais entre determinados tipos de parentes. Antes, algo ruim poderia acontecer, mas não se tinha clareza sobre as consequências, agora, algumas ações negativas (khema) carregam consigo uma espécie de punição objetificada e (quase) impossível de ser evitada.

\section{O cosmos, Hamu e o problema do incesto}

Khema tem consequências cósmicas especificadas, embora, nos dias de hoje, apenas um dos comportamentos khema o cause, aquele que torna as pessoas Hamukha (onde Hamu é um nome próprio e kha indica o possessivo). Formulada para Ego masculino, os Deni afirmam que não podem ter relações sexuais com a "sogra" (ashu), a "nora" (uhirumadini) e a "irmã" (adi e ukharipene ${ }^{281}$ ), é imadipei, khema. No plano normativo, estas são as relações que envolvem maior separação e controle nas ações, uma disjunção máxima corporal e uma moderação da linguagem. $\mathrm{O}$ perigo destes

\footnotetext{
${ }^{280}$ Veja capítulo 1.

${ }^{281}$ Veja abaixo quando discutirmos a terminologia de parentesco.
} 
comportamentos só se manifestam no post mortem, quando a alma daquele que se tornou Hamukha chega ao céu (neme) e é canibalizada por Hamu.

Durante nossa pesquisa, só obtivemos informações sobre um homem que havia sido canibalizado por Hamu, embora as acusações apontem que quase todas as pessoas casadas desrespeitam a regra, contraindo matrimônios, ou tendo relações sexuais, com quem não deveriam. Questionando algumas pessoas sobre o problema de seu casamento impróprio (algo extremamente ofensivo e que, portanto, não foi possível explorar detalhadamente) que o faria ser comido por Hamu, invariavelmente apontavam que a diferença na identidade_deni fazia com que a união não fosse problemática. O estado de Hamukha parece ser algo que se estabelece a partir de um cúmulo de cheiros proibidos, principalmente aqueles que resultam da relação de parentesco entre os cônjuges que compartilham uma ligação de parentesco agnático, forma pela qual é transmitida a identidade de subgrupo (a parte compartilhada da pessoa).

Alguns associam Hamu com Satanás, sendo ele o responsável por realizar uma espécie de julgamento dos mortos. Pela descrição dos Deni, quando alguém morre, sua alma (abanu) é levada para o céu por um xamã (zuphinehe), eles seguem por um caminho (que nunca será visitado novamente pelo morto) no qual há diversas árvores frutíferas que são tão baixas que os frutos poderiam ser colhidos facilmente. Hamu fica em uma encruzilhada, quando o morto e o xamã chegam nela, Hamu pega a alma pelo pescoço, esfrega a mão na cabeça desta e cheira a própria mão. Desta forma ele sabe quem teve relações sexuais com "sogra" ou com "irmã" e quebra seus pescoços, entregando os pecadores para serem comidos em sua aldeia durante uma grande festa. Aqueles que não são Hamukha, não têm cheiro, podem seguir pelo caminho que leva para as aldeias celestes.

É interessante que os Deni realizam uma disjunção entre locais do cosmos que aparecem fundidos no cosmos Kulina. Entre os Deni, há quatro patamares básicos com relevância direta para os madiha: o subterrâneo (nami budi - morada dos animais); o aquático (pashu budi - para onde vão alguns mortos, como os xamãs); o terrestre (da superfície da terra, onde estão as aldeias dos humanos) e; o celeste (neme). Os animais vivem em nami budi (os grandes mamíferos encontrados nos barreiros, como as antas, caititus, queixadas, mas não os macacos) e quando sobem para a terra podem ter seus corpos (do ponto de vista dos humanos, alma do ponto de vista deles) roubados e comidos pelos humanos. As almas humanas, quando vão para neme, podem ser comidas 
por Hamu que as vê como um corpo, ou seguem para uma aldeia celeste habitada por espíritos (tukurime) e pelos mortos.

Para os Kulina, o destino post mortem dos humanos é ser levado por um xamã para o subterrâneo ${ }^{282}$, o nami budi. As almas são deixadas na aldeia das queixadas, onde acontece um ritual durante o qual os mortos são comidos e transformados em queixadas, ou seja, as queixadas são os espíritos transformados dos mortos Kulina. O xamã (tal como acontece entre os Deni) vai até nami budi e atrai as queixadas para os caçadores humanos da superfície, sendo que o consumo dos animais, segundo Pollock (1993: 62), faz com que a alma deles se torne as almas ou espíritos de seus descendentes. O cosmos Kulina é, assim, cíclico, pessoas morrem, viram queixadas, são consumidas e assim voltam a compor as pessoas vivas. Há uma alternância entre humanos e animais, em um devir canibal no qual mudam as perspectivas entre os que comem e os que são vistos como comida.

A questão das almas parece ser diferente no contexto Deni, pois, não parece haver relação entre a constituição das almas e a alimentação. Não parece existir, também, uma única origem para as almas das crianças que nascem, sendo que duas possibilidades são de amplo conhecimento, mas elas, até onde sabemos, não respondem pela totalidade dos nascimentos. Quando alguém morre, geralmente se é criança, a alma do morto pode vir a renascer, algo que acontece ou pela sua própria vontade, ou por intermédio de um xamã, que pode atender ao pedido dos pais da criança e pegar sua alma para ser colocada novamente no útero da mãe (ou de outro parente). Nestes casos, a criança será chamada de $\operatorname{abanu}(n i)^{283}$, podendo, também, ser conhecida e chamada pelo nome de sua vida anterior. Pessoas nascidas a partir do espirito de um morto podem conservar a memória de sua vida antiga e, no caso de não terem nascido novamente da mesma mãe e pai, podem vir a se referir a eles desta forma, sendo que, algumas delas, possuem memória do que vivenciaram após a morte.

A outra possibilidade diz respeito às almas de origem animal ou planta que podem, espontaneamente, se introduzir na mãe, ou serem colocadas por um xamã. Neste último caso, o xamã vai de encontro a uma entidade do cosmos e negocia com ela para

\footnotetext{
${ }^{282}$ Como chama a atenção Gordon (2006), apenas uma das almas Kulina vai ao mundo subterrâneo. Na interpretação deste autor, não há um ciclo no cosmos Kulina, pois, as queixadas transformam os mortos em seus próprios parentes, enquanto o consumo humano das queixadas serve para criar o parentesco entre os humanos, não sendo as queixadas que se tornam parente.

${ }^{283}$ A terminação_ni indica o feminino.
} 
obter seu filho/alma, sendo que, no curso da negociação, usa o rapé (elemento central do xamanismo na região) para obter a criança. Pessoas nascidas desta forma não deveriam comer dos animais ou plantas que lhe são familiares, o que se associa com a ideia de que na caça os madiha obtêm o corpo do animal que, ao ser consumido, causa a morte da alma, quando esta já retornou para sua aldeia. Comendo do animal (bani) que forneceu a sua alma, a pessoa poderia vir a comer seus próprios parentes, ou mesmo seu próprio corpo, dado que as almas são múltiplas como apontamos no capítulo 2 .

As almas que não tiveram estas duas origens parecem surgir a partir do sangue e do sêmen, mas isto não é uma afirmação dos próprios Deni. Esta possibilidade é dada pela associação entre alma e sangue, sendo que o resultado da relação sexual com uma mulher menstruada é o surgimento de uma entidade (imari madiha) composta por almas/fragmentos de cada um dos amantes. O surgimento desta entidade não causa muitos problemas para o casal, ela, apenas, faz comentários constrangedores a respeito de quem teve relações sexuais inapropriadas. Através da intervenção de um xamã, ela pode ser decomposta e as almas são reintroduzidas nos corpos nos corpos daqueles que lhe deram origem.

Voltemos à questão da diferença entre as escatologias Kulina e Deni. Entre estes últimos, há uma preocupação dos humanos em se afirmarem como os comedores/caçadores do patamar terrestre, fixando os animais na posição de presa. Há, entre eles, uma disjunção entre a origem dos animais na terra e o destino dos humanos no céu, pois, no post mortem, os Deni não vão para nami budi, onde vivem e morrem os animais, mas para o céu (ou a água em casos especiais ${ }^{284}$ ), onde encontram Hamu e podem, ou não, ser comidos por ele, sendo que os devorados cessam de existir ${ }^{285}$, não nascem novamente e nem se considera que são transformados em Hamu. Que houve uma disjunção de coisas que poderiam estar unidas anteriormente é perceptível na própria cosmologia Deni, pois há dois Hamu nos dias atuais: este do céu e um relacionado com as queixadas.

Alguns caçadores relatam que é possível ver um dos Hamu correndo na frente dos bandos de queixadas, há, inclusive, uma narrativa muito difundida (existe até uma versão na coletânea do Xeruã editada por Sass 2004) que é associada com ele, mas os

\footnotetext{
${ }^{284}$ Os xamãs seguem, invariavelmente, para as aldeias do mundo das águas, enquanto alguns dos humanos gostariam de seguir para lá devido ao temor de serem julgados por Hamu.

${ }^{285}$ Frente aos repetidos questionamentos respondem rindo que se tornam as fezes de Hamu.
} 
Deni são categóricos em afirmar que não se trata do mesmo Hamu do céu. Em resumo, a narrativa diz que Hamu era um caçador que se afastou da aldeia perseguindo um bando de queixadas e, após certo tempo, se tornou uma queixada. Os outros caçadores, um dia, encontraram o bando e o reconheceram, o capturaram e reverteram a sua transformação. Ele passou a atrair as queixadas até que um dia matou sua esposa queixada e seus filhos. Hamu é aqui uma entidade que faz o que os Kulina apontam como sendo o ciclo de vida, humanos viram queixadas e queixadas viram humanos, porém ele é, no fundo, um canibal, pois come os próprios parentes-queixadas.

A proibição do incesto Deni, isto é, a mistura de cheiros não apropriados, e o julgamento post mortem parecem ser uma transformação a partir de algo que se aproximaria do contexto Kulina. Houve uma rotação em que o caminho dos mortos deixa de ser aquele das queixadas e passa a ser semelhante ao que dizem os kariva, o que se assenta ao que apresentamos no capítulo 1. No contexto atual, os animais e humanos não compartilham jamais uma identidade, os kariva assumem o lugar da afinidade, dos não parentes, da alteridade com quem se guarda certa semelhança, o que os torna passíveis de se tornarem parentes. Da mesma forma, os imaamushinaha que tinham relação com o cancelamento do imadipei, pelo restabelecimento da estética madiha, agora neutralizam as ações negativas dos kariva, compartilhando de seus rituais (futebol) e musica (forró).

Muitos dos Deni mais velhos e pouquíssimos dos jovens casaram durante a execução de um imaamushinaha. Após uma noite de cantorias, ou durante a ausência do noivo para participar da caçada coletiva, sua rede era levada e atada ao lado da rede de uma moça com quem ele teve relações sexuais (uma ou muitas). Nestes eventos, alguns homens eram atraídos para a aldeia em que se realizava a festa através do matrimônio (alguns dos que casaram com mulheres não indígenas voltaram para aldeia através desse método), mas, algumas dentre elas, eram uniões em que existia imadipei. Muitas uniões ocorridas desta maneira envolviam cônjuges que, segundo boa parte das pessoas, não mantinham a relação de parentesco apropriada, mas parece que, ao ser efetivada a união no curso de um imaamushinaha, o perigo era retirado da união. 


\section{Os processos de casamento}

Os Deni apontam que a forma apropriada de casamento consiste em um homem (e/ou seus parentes) pedir para os pais de uma moça para casar com ela. A partir deste momento, caso o pedido seja aceito, se inicia o serviço da noiva (Shapiro 1984), formulado enquanto a derrubada de açaí, a construção de casas, a entrega de caça ou peixe e a abertura de roçados para os sogros. Na prática, há outras quatro formas de casamento: alguns trocam as irmãs; outros "roubam" a esposa (não fazem o pedido); são casados durante os imaamushinaha e; por último, há os casamentos que se efetivam por meio de uma reunião. A heuniau (na pronúncia deni), mesmo que não seja uma atividade desconhecida anteriormente, parece ocorrer com mais frequência nos tempos recentes, havendo reunião para tudo, desde assuntos ligados aos casamentos até relações interétnicas, caçadas coletivas, etc..

As reuniões, talvez não exatamente no formato atual que se assemelha ao tipo realizado pelo movimento indígena (há uma sucessão dos discursos dirigidos aos presentes), deviam existir anteriormente, tal como ocorre entre os Kulina. Segundo Altmann (1994), estes realizam reuniões em os chefes perguntam às mulheres solteiras sobre seus parceiros sexuais, para que seja assegurado que os homens realizem as retribuições apropriadas. No contexto Deni, as reuniões são convocadas por qualquer pessoa que tenha um assunto a tratar com a comunidade, as relacionadas aos casamentos são, comumente, realizadas por parentes dos cônjuges em potencial, não necessariamente seus pais e irmãos.

Estas reuniões ocorrem, geralmente, quando os casamentos que se quer efetivar representam um problema para a aldeia, ou seja, envolvem pessoas que já estão envolvidas em outros casamentos e são condenados, explicitamente, pela maioria, que verbaliza essa insatisfação. Elas atuam como ferramentas de harmonia ('tools of concord' - Alès 2000) ou de concordância, utilizadas de forma a manter as boas disposições, evitando que ocorram fissões ${ }^{286}$ na aldeia, que levariam ao surgimento de inimizades e potencialmente da guerra. Uma das reuniões de casamento da aldeia Cidadezinha ilustra bem este processo, tendo ocorrido há uns 8-9 anos atrás (2004-5). Ela envolveu quatro casais que foram desfeitos e alguns dos cônjuges contraíram novos

\footnotetext{
${ }^{286}$ E de fato, alguns Deni apontam o adultério como causa das fissões que resultaram nas aldeias atuais. Outros fornecem outras explicações, como a violência, a falta de salários para os descendentes de um dos fundadores das novas aldeias, etc..
} 
matrimônios em seu curso. A situação no início da reunião pode ser ilustrada pela figura abaixo.

Figura 2 - Situação matrimonial inicial

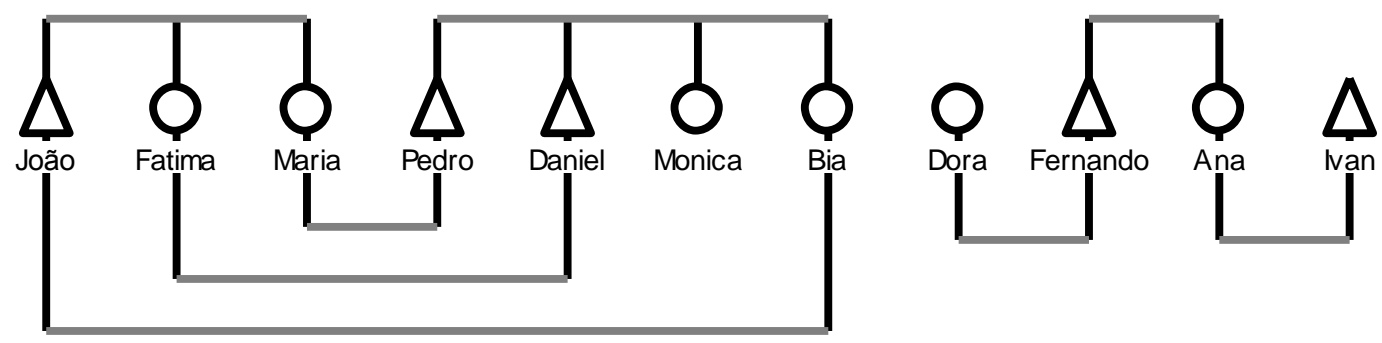

O casal Maria e Pedro foi o primeiro a estabelecer uma relação de aliança entre os dois conjuntos de siblings representados a esquerda, tendo seu casamento ocorrido pelo menos cinco anos antes dos que os outros. Daniel, irmão mais novo de Pedro, contraiu posteriormente matrimônio com Fatima, irmã de Maria e teve com ela um filho. Combinaram que João, um rapaz ainda muito novo, se casaria com Bia, irmã de seus dois cunhados. Havia sido estabelecida, assim, uma troca de irmãs, forma ideal do casamento para os Deni, que garante uma esposa para cada homem e aproxima todos os membros das duas famílias.

Os irmãos Fernando e Ana eram originários de outra aldeia e se mudaram, junto com seus cônjuges, pais e irmãos solteiros, para a Cidadezinha, onde um de seus irmãos havia casado fazia muitos anos. Após a sua chegada, Fernando passou a namorar com Bia e Ana com Daniel, isto seguiu sem maiores complicações, até que Daniel e Fernando resolveram trocar suas irmãs que eram casadas com outros homens. Isto foi mal visto pelos moradores da aldeia que expressavam abertamente a condenação do acordo, pois ele envolveria desfazer os casamentos das mulheres, sendo que uma delas estava envolvida em uma troca de irmãs. 
Figura 3 - Uniões matrimoniais desfeitas

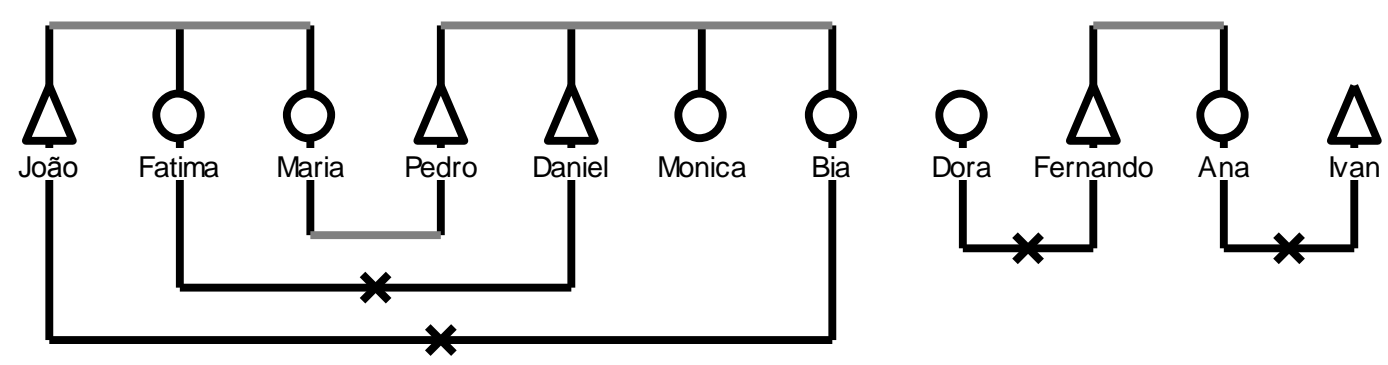

$\longrightarrow$ Casamentos que deveriam ser desfeitos

O novo arranjo proposto não foi bem aceito, a família de Bia e Daniel era contra a união entre Fernando e Bia. Esta situação perdurou por algum tempo, gerando muitas acusações contra a família que havia ingressado recentemente na aldeia. Um dos membros desta havia, contudo, se casado com a irmã de um dos patarahu da aldeia fazia muitos anos e já tinham muitos filhos, ou seja, a indisposição com eles poderia trazer também maiores consequências para outros arranjos matrimoniais bem estabelecidos. A tensão cresceu até o ponto em que fizeram uma reunião, ao final da qual foi estabelecido um novo arranjo matrimonial para alguns dos envolvidos. O resultado da reunião está representado na figura abaixo.

Figura 4 - Os casamentos após a reunião

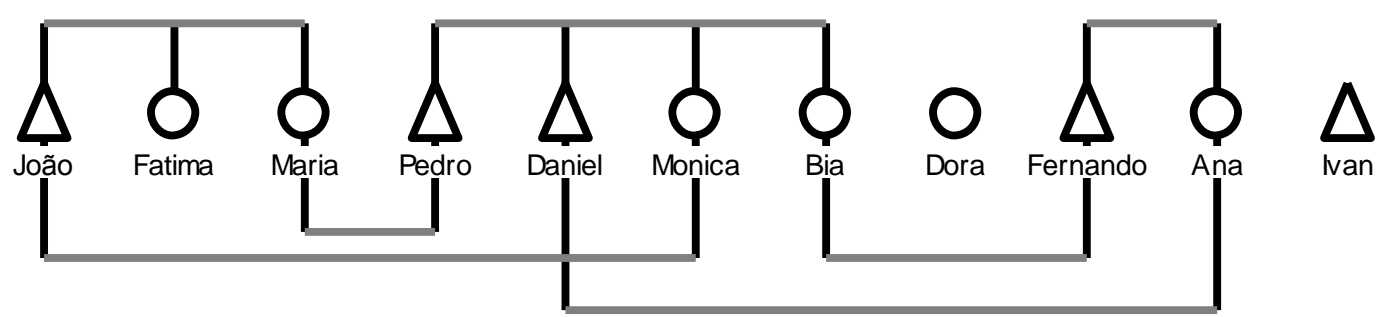

No novo arranjo, João recebeu outra irmã de Daniel, garantindo que ele continuasse casado com uma irmã de seu cunhado (Pedro), ou seja, foi mantida a troca de irmãs que seria desfeita com o termino do casamento entre João e Bia. Daniel e 
Fernando trocaram as irmãs e se comprometeram a não abandonarem novamente as esposas - já era o terceiro casamento de ambos. Dora, originária do Xeruã acabou retornando para a sua aldeia, tendo deixado a filha do casal para ser criada pelos pais de Fernando. Ivan obteve, posteriormente, uma noiva, mas acabou por abandonar a aldeia antes da concretização da sua nova união.

Este caso é representativo dos processos de casamentos por meio de uma reunião, que envolvem, sempre, uniões criticadas publicamente. Durante elas, as pessoas argumentam sobre o porquê de determinada união dever ou não ocorrer, sendo que a resolução busca sempre evitar a ruptura, o surgimento da inimizade, sendo sempre, até onde sabemos, concluída com a realização de um arranjo que converte os amantes anteriormente criticados em cônjuges reconhecidos, mas não, necessariamente, aprovado por todos. Não se trata de um momento em que as pessoas são convencidas de que devem mudar suas disposições, mas um evento em que aqueles que poderiam se tornar inimigos são efetivados como afins, restabelecendo, assim, a harmonia, passando das más para as boas disposições, cessando os conflitos internos.

Pollock aponta que há um paradoxo entre os Kulina, pois estes consideram que a aldeia endogâmica é um grupo de siblings, ou seja, todos os moradores seriam como irmãos, consanguíneos entre si, mas devem casar uns com os outros. Segundo a interpretação deste autor, esta visão de serem todos irmãos está relacionada com o universo da convivialidade, enquanto que a afinidade e a sexualidade representam as maiores ameaças a harmonia dos siblings (2004: 212). O problema está na relação de liberdade que alguém experimenta com seus siblings, que é continuamente ameaçada pelo estabelecimento de uma "relação baseada em regras mais explicitas de conduta, estrutura e o cálculo de reciprocidade" (2004: 212).

Há, assim, uma semelhança entre os Deni e os Kulina, mesmo que suas reuniões sirvam a propósitos opostos. Enquanto que, para os últimos, a aldeia é um grupo consanguíneo e a sexualidade é uma ameaça por criar a afinidade em seu meio, sendo as reuniões uma forma de garantir que afins mantenham o comportamento apropriado de afins com os afins; para os Deni, a aldeia é um conjunto composto, atualmente, por consanguíneos e afins (que só no limite são uvibuva), sendo a sexualidade uma ameaça pelo seu potencial de converter afins em inimigos. A reunião entre eles é uma ferramenta para garantir que afins tenham comportamento de consanguíneos com o resto da aldeia, isto é, não continuem a se tratar como quase inimigos. Para uns, o mau 
da união entre consanguíneos é controlado pela manutenção de uma regulamentação rígida da vida entre os afins, para outros, o mau da contra efetuação (Viveiros de Castro 2002) do parentesco é harmonizado pelo restabelecimento de um convívio apropriado entre os parentes.

\subsection{Nominação}

Talvez o único par que apresente um vínculo que existe antes de se estabelecer uma ligação de parentesco seja aquele formado por nomeador e nominado. Dada ser uma relação que se estabelece assim que ocorre o nascimento, ela substitui, inicialmente, qualquer relação de parentesco que poderia ser traçada entre ambos. A nominação pode, contudo, dar lugar ao estabelecimento de uma relação de afinidade, transformando o par nominador/nominado em uma relação de sogro/genro ou sogra/nora ou de cunhados, isto é, pode ser estabelecido um vínculo de parentesco (no limite) inexistente anteriormente.

Idealmente, quando ocorre o nascimento de uma criança, uma pessoa, de mesmo sexo que aquele que nasce, é convidada para cortar o cordão umbilical. Este ato faz com que cortador e recém-nascido passem a compartilhar um mesmo nome e, no futuro, se tratarão pelo termo reciproco de $u n i^{287}$ ("nome"). Na prática, pelo que pudemos perceber, muitos cordões umbilicais, ao menos nas últimas décadas, foram seccionados por uma das avós $\left(\mathrm{MM}^{288}\right.$ mais frequentemente que $\left.\mathrm{FM}\right)$ da criança, sem que haja a transmissão de nome. O pai parece desconhecer quem foi responsável pelo corte do cordão da maioria, senão de todos, os seus filhos. Muitos nomes foram transmitidos (ou absorvidos) sem que ocorresse o corte do cordão, o que é particularmente frequente quando se tratam de nomes dos não-Deni com quem eles se relacionaram, existindo muitas pessoas homônimas dos missionários, enfermeiros, técnicos de enfermagem, antropólogos, funcionários da FUNAI, das ONGs e etc., que atuaram na região.

É possível que, anteriormente, acontecesse entre os Deni algo semelhante ao que Gow aponta para os Piro, entre os quais aquilo que nasce precisa ser confirmado como

\footnotetext{
${ }^{287}$ Koop \& Koop: “uni (sm.) nome; xará. (fem: unini)” (1985 :91)

${ }^{288}$ Pela tendência a residência uxorilocal, é possível que esta preferência pela avó materna tenha relação com a proximidade física desta quando ocorre o nascimento. Um dia, uma senhora disse que cortaríamos o cordão do filho de sua filha caso nascesse um homem, o que não aconteceu. É possível que seja a avó que decida sobre quem realizará o corte do cordão, porém não temos certeza quanto a isto.
} 
um humano ${ }^{289}$, e somente após esta confirmação ocorre a "busca de um não parente para perfazer a Humanidade do novo humano" (1997: 48). Num passado não muito remoto, a prática do infanticídio foi abandonada, embora, algumas pessoas, ainda se recordem de alguns não humanos de nascença que foram mortos ao surgirem. Estes casos, que são condenados nos discursos atuais dirigidos ao antropólogo, são lembrados como envolvendo o nascimento de crianças feias, tal característica sendo um dos indicativos de que se tratava de um kuruvi.

Kuruvi é o nome de uma entidade que nasce após um espirito (tukurime) ter relações sexuais como uma mulher. O nascimento de um kuruvi leva a morte da mãe durante o parto, pois causa uma hemorragia fatal. Apenas em décadas passadas eram observados estes nascimentos, possivelmente, ainda no tempo em que precisavam garantir a humanidade daquilo que a mulher paria. Agora, todos os paridos são considerados da mesma forma, são tratados como gente, sem existir a necessidade de uma inspeção previa para garantir sua humanidade.

O termo kuruvi é empregado, atualmente, para se referir a qualquer portador de deficiência mental ou física, seja de nascença ou adquirida, mas, quando usado como vocativo, parece ser uma forma de ofensa. Parece que a kuruvi-dade de alguém está relacionada, atualmente, com sua capacidade de funcionar plenamente, isto é, aqueles que não dominam a linguagem ou não são capazes de desempenhar tarefas ordinárias são kuruvi, mesmo que não apresentem problemas visíveis. Alguém que é apontado como kuruvi sempre vai ter alguma falta associada: não fala direito, não consegue trabalhar, só sabe fazer uma tarefa ("só sabe pescar", "só sabe lavar roupa”, etc.).

O nascimento de um kuruvi, nos dias de hoje, não parece constituir uma ameaça ao socius. Após a interação persistente com alguns missionários da JOCUM $^{290}$, consolidou-se a ideia de que os que nascem kuruvi podem ser "aposentados" e que há uma cidade perto de Porto Velho onde todos os kariva kuruvi habitam e eles vivem bem. Esta última ideia parece ter sido difundida por um Deni que há uns 30-40 anos sofreu um acidente que o deixou aleijado, tendo visitado essa cidade durante o seu tratamento. Entre os Deni, contudo, os kuruvi não podem viver plenamente, seus pais não querem que eles casem, mesmo que alguém se interesse em desposá-los, é imadipei, dizem. Novamente,

\footnotetext{
${ }^{289}$ A possibilidade de nascimento de um não humano parece ser algo comum na Amazônia. Veja Vilaça (2002)

${ }^{290}$ Os mesmos que combatem os Suruwahá em torno da questão do infanticídio.
} 
não saberíamos dizer quais seriam as consequências do casamento dos kuruvi, pois as relações sexuais parecem não trazer resultados negativos.

Atualmente, todos aqueles que nascem podem receber o nome do cortador do seu cordão umbilical, há pessoas que receberam nomes mesmo sendo kuruvi de nascença. Esta doação de nome não acarreta a perda por parte do doador, ele e o receptor passam a possuir a designação de forma compartilhada. As pessoas que não são envolvidas diretamente pela relação passam a se referir ao doador como "nome doado" hurasha e ao receptor como "nome doado" zati. Hurasha e zati são adjetivos que denotam o velho e o novo, respectivamente.

No vocativo, o doador vai, geralmente, continuar a ser referido pelo seu nome, porém, comumente, as pessoas utilizam termos de parentesco como vocativos quando estão conversando. A utilização de tecnonímos ou nomes pessoais ocorre quando chamam alguém com quem não estão interagindo, agindo como forma de chamamento mais do que tratamento. O recebedor, na maioria das vezes, será chamado pelo nome acrescido pelo sufixo_zi. Por exemplo, o Tata Zati era comumente chamado de Tatazi. É possível que $z i$ seja uma contração de zati, ou mesmo que seja um diminuitivo que é aplicável ao nome de qualquer pessoa mais nova. A Mara, por exemplo, era chamada de Marazi por muitas pessoas mais velhas do que ela, mesmo não existindo uma Mara Hurasha.

Se for o primeiro filho, os pais do nomeado têm seus nomes modificados, o pai poderá ser chamado por "nome doado" mais o sufixo me e a mãe pela adição do sufixo meni. A tecnonímia, pela adição dos sufixos me e meni, pode ser aplicada para todos os nomes do primeiro filho, porém, apenas um, dentre os muitos possíveis, é utilizado. $\mathrm{Na}$ prática, parece ser o nome pelo qual a criança é referida pela maioria das pessoas aquele que será utilizado na composição do tecnonímo.

Antes de prosseguirmos nas considerações acerca das relações que se estabelecem após o corte do cordão umbilical, seria este o momento para apresentar as formas como ocorrem a nomeação. Algumas já foram indicadas anteriormente, mas a onomástica Deni é complexa, já que, cada pessoa, pode ou não ser nomeada a partir de uma das maneiras correntes. Há muitas formas de se obter um nome, podendo ser alterado o nome pelo qual a pessoa é conhecida em qualquer momento, inclusive pela sua própria vontade, caso seja adulto. 
De forma semelhante aos Pirahã, todos os elementos do mundo possuem um nome (uni/unini), podendo ser considerado que, para os Deni, ter um nome "significa ter existência" (Gonçalves 1993: 37). A nomeação marca o estabelecimento de uma singularidade, mas que não necessariamente coincide com uma entidade semelhante à categoria ocidental de indivíduo (ou corpo), ou exemplar (de determinado objeto ou espécie), podendo se situar enquanto uma das divisões que mostramos no capítulo 2. Nesse sentido, identificam o nome (uni/unini) do animal como sua espécie e os subgrupos tornam-se parte do nome pessoal (quando fazem registros civis de nascimento ${ }^{291}$ ), ao mesmo tempo em que marcam toda e cada uma das pessoas humanas e algumas das não humanas de forma singularizada. Os xamãs animais possuem nomes próprios, há espíritos que possuem nomes pessoais, mas no que diz respeito aos animais não está claro se cada um possui um nome próprio, ou se vários xamãs recebem um mesmo nome.

Existem muitas fontes diferentes de nomes. Como dissemos anteriormente, algumas pessoas possuem nomes de plantas ou animais e estes podem ser tanto os das espécies, quanto de algum xamã-animal em particular. Há, também, aquelas nomeadas Abanu/Abanuni, as pessoas que nasceram novamente e que possuem, igualmente, a designação utilizada para seu corpo anterior. Há pessoas que portam a alcunha de alguém já falecido sem serem, contudo, uma reedição da alma deles, possuindo apenas o mesmo nome, o que pode acontecer também entre vivos que não habitem na mesma aldeia.

Os Deni, pelo uso do termo $\operatorname{pina}^{292}$, indicam que algo não esta relacionado com outra coisa para além do que é imediatamente percebido. Por exemplo, quando se reúnem algumas pessoas apenas para conversar, sem ter algum assunto a debater, ou fazem somente uma visita ao antropólogo, sem ser para pedir alguma coisa, ou quando desenham algo que não corresponde a nada. Quando perguntados se a coincidência nominal entre um dos filhos e um parente morto há muito tempo teria relação com a reencarnação ou o corte do cordão diziam que era somente (pina) o nome.

\footnotetext{
${ }^{291}$ É interessante notar que, segundo alguns, a forma para descobrir o pertencimento de subgrupo de determinada pessoa seria perguntando qual o nome dela. A pergunta do nome, contudo, quase sempre recebia como resposta um dos nomes sem a referência ao subgrupo, que só surgia em contextos em que o nome do registro parecia ser o nome (uni/unini) relevante.
}

${ }^{292}$ Pina. 1 (adj.) só. 2 (adv.) apenas, somente. - Koop \& Koop (1985) 
Ter o mesmo nome, sem ter realizado o corte de cordão, parece não estabelecer uma relação entre o nomeador e a família do nomeado. Isto é válido tanto para os nomes em português, cujos doadores muitas vezes sequer são avisados de que seus nomes foram dados para alguma criança, quanto para os nomes na língua deni. $\mathrm{Na}$ Cidadezinha, existem alguns nomes que são apontados como ocorrendo também no Xeruã, mas não foram transmitidos pelo corte de cordão, e sim, dado pelos pais. A relação dada pela nomeação tem que ser estabelecida, do contrário há apenas uma coincidência dos nomes, e não uma identidade compartilhada.

Esse adquirir nomes para os filhos, independente de transmissão, parece ocorrer com os nomes dos não indígenas, os "nome de branco" com que, até recentemente, eram obrigados a se registrar nos cartórios da região. Eles se originam a partir do contato com os não-Deni, sendo assumidos inicialmente aqueles utilizados pelos extrativistas quando chamavam os Deni, mas, agora, eles correspondem aos nomes ou apelidos de pessoas com quem entraram em contato, isto é, são nomes conhecidos e incorporados. Esse conhecer um novo nome/pessoa permite que sejam aplicados pelos pais aos recém-nascidos sem, contudo, se estabelecerem os vínculos decorrentes da transmissão, são apenas nomes aprendidos, apreendidos e incorporados. Uma menina, nascida em início de 2012, por exemplo, foi nomeada Dilma, mesmo que o pai dela jamais tenha visto a presidenta, tendo apenas escutado seu nome.

Cada pessoa possui muitos tipos diferentes de nomes, parecendo que o único realmente obrigatório, isto é, que todos possuem e utilizam, é o dos brancos (karivakha _ _kha é o possessivo). Estes, que podem vir a se tornar de uso corrente no cotidiano, chegando ao ponto dos moradores da aldeia Cidadezinha no rio Cuniuá só conseguirem fornecer nomes em português para muitos moradores do Xeruã, sempre são fornecido aos não-Deni. Os Deni utilizam estes nomes para responder a pergunta "Qual é seu nome?" que muito escutam durante suas estadias nas cidades e vilas da região. Não há qualquer problema com a enunciação do próprio nome na língua deni (madihakha uni), há, inclusive, alguns casos nos quais a pessoa escolhe seu próprio nome (não tecnonímico).

Mesmo que, potencialmente, todos possam ter todos os tipos possíveis de nome, muitos são esquecidos ou deixados de lado, como um pai que dá seu nome para seu filho (e dessa forma o perde), ou um nome dado pelo corte do cordão, mas que ninguém lembra, ou o nome da outra vida que é esquecido. As listas de nomes dos moradores de 
cada aldeia mantidas pela FUNASA são impossíveis de serem utilizadas sem a presença do AIS, que parece ser o único capaz de vincular os primeiros nomes (que foram usados nos primeiros momentos após o nascimento e fixados nas planilhas de controle) e as pessoas, já que muitas acabaram sendo conhecidas por outras designações que não a que possuíam inicialmente.

No continuum onomástico, do exonímico ao endonímico (Viveiros de Castro 1986), os Deni parecem ocupar as duas pontas, já que há os "nomes de xamã" que vêm de fora (adquiridos) e os aqueles que se transmitem com o corte do cordão. A feição exonímica apresenta um claro correlato entre o nome adquirido fora e uma "teoria conexa sobre a alma" (Viveiros de Castro 1986: 384. nota 66), aqueles que possuem nome de animal ou planta informado pelo xamã possuem também uma alma ( $a b a n u)$ de origem animal ou planta. Os nomes transmitidos, contudo, parecem estar relacionados com a teoria de identidades singulares formadas pela fusão de semelhantes, isto é, a noção de _madi apresentada no capítulo 2. Não se trata de um compartilhamento de almas, mas de aspectos da pessoa.

Há os nomes classificatórios, como Abanu/Abanuni, empregados para aqueles que são reedições de pessoas já falecidas, e os nomes individualizantes, como apelidos dados por certas pessoas que podem vir a se difundir, ou mesmo nomes dados devido a eventos ocorridos durante a gestação. A individualização nominal por apelidos ocorre, por exemplo, quando um rapaz que corre muito é apelidado, pelo seu tio (FB), com o nome de uma espécie de ave que apresenta este comportamento, passando posteriormente a ser conhecido assim por todas as pessoas (influenciando até a tecnonímia). São idiossincrasias pessoais que acabam por gerar apelidos que se tornam nomes individualizantes.

Aqueles que se relacionam com acidentes durante a gravidez podem indicar desde eventos negativos, como nomear o filho de forma a lembrar das brigas que teve na aldeia (esta forma apesar de muito recorrente resulta em nomes diversos), até positivos, como dar o nome do barulho que fazem as antas, porque o pai matavam muitas durante a gravidez da esposa. Não são poucos os designativos exclusivos, alguns são tão singulares que só fazem sentido levando-se em conta o contexto. Muitos dos nomes, sejam apelidos por características pessoais ou descritivos de eventos, não são 
facilmente traduzíveis, seu significado vai depender do conhecimento do contexto e da história, que os tornarão inteligíveis ${ }^{293}$.

Os Deni me deram o nome de Vizarivi, que teria relação com o verbo _vizaza “(v. intr.) mover para cima e para baixo (coisa flácida que se leva nas costas, etc.)." (Koop \& Koop 1985: 97), que associavam com o movimento oscilatório que a vara de pesca faz quando se anda com ela apoiada no ombro. Para ser uma frase descritiva o nome deveria ser vizaza.ri.vi, em que vizaza é o verbo na terceira pessoa, _ri sufixo verbal indicativo de ação completada ou em curso e _vi sufixo que indica nome masculino, mas, na composição do nome, modificaram o verbo e isto faz com que ele se tornasse diretamente inteligível, apenas, para aqueles que me conhecem. Essas composições tornam cada identidade exclusiva, ao ponto de só poderem ser entendidas quando a singularidade do corpo e da história pessoal é conhecida.

A transmissão nominal entre os Krahô (Melatti 1970) estabelece uma relação, por um lado, semelhante àquela que existe entre os Deni e, por outro lado, muito diferente. Os nomes compartilhados tanto entre Deni quanto entre os Krahô realizam espécies de torções no campo relacional subvertendo o mapeamento via parentesco. Entre os Deni, contudo, não existe nada como papéis sociais ligados aos nomes pessoais, como é comum entre os Jê-Timbira, entre os quais os nomes informam posições sociais e prerrogativas rituais, como o pertencimento a metades.

Os nomes não parecem se constituir como uma espécie de patrimônio, não há nada como grupos detentores de bens, valores e prerrogativas, mas os Deni tentam conservá-los. Sabemos de alguns casos nos quais o filho de um homem, que abandonou a esposa e foi embora, passou a ser chamado pelo nome do pai, mantendo o nome da pessoa que se afastou ${ }^{294}$. Caso a criança receba o nome de um pai presente, há uma transferência, perdendo o transmissor em favor do filho, que passa a possuí-lo de forma exclusiva. Há alguns designativos que se transmitem entre vivos de forma ritual (pelo corte do cordão), mas outros são adquiridos sem implicar o detentor original em uma relação, outros são repetidos de parentes já mortos...

\footnotetext{
${ }^{293}$ Esta necessidade contextual para tornar os nomes inteligíveis é vista também nos cantos (mishe), que só podem ser entendidos pelas pessoas que conhecem o contexto em que foi criado. Altmann (1984) aponta algo semelhante para os Kulina, afirmando que, embora dominasse o idioma, muitas coisas ditas eram ininteligíveis por faltar o contexto a que remetiam.

${ }^{294}$ Não podemos afirmar que é sempre assim, pois só tivemos contato direto com um caso destes, mas havia uma criança abandonada pelo pai de outra aldeia que começou a ser chamada pelo nome do pai ausente até que a mãe contraiu novo matrimônio.
} 
A transmissão ritual entre vivos não parece se submeter a uma regulamentação, não há qualquer ideal expresso ou preferência facilmente observável, não são pessoas que mantêm determinadas relações de parentesco com a criança, nem que sejam coresidentes, nem que sejam de subgrupos diferentes, etc., que transferem preferencialmente o nome. Talvez o único parâmetro relevante seja que há a necessidade de existir uma distancia mínima entre doador e receptor, pois, até onde sabemos, não há irmãos que doaram nomes entre si. A questão parece ser de internalização de diferenças e mistura, ampliando os limites distinguíveis do "Nós".

A transmissão de nome leva ao compartilhamento de uma existência, marcando uma singularidade, porém, não há identidade plena entre nomeador e nominado, eles mantêm uma relação, logo, uma diferença. Entre eles há o uso do termo de tratamento recíproco uni (nome), mas não há simetria na relação, a diferença de idade sendo o parâmetro irredutível de diferença (o mesmo que diferencia os irmãos gêmeos). Este par mantem-se no modo relacional da dádiva, do mais velho para o mais novo, o primeiro presente é o nome e, posteriormente, outros seguirão para o nomeado, numa espécie de hiper-filiação, que envolve também o cônjuge do nomeador.

Em certo sentido, a relação nomeador-nomeado é semelhante aquela entre pai e filho, o nomeador é um provedor para o nominado, mas não parece haver qualquer obrigação do segundo para o primeiro. Parece que ambos são, na verdade, uma mesma coisa (apenas um uni em diferentes aspectos ou corpos), assim, o mais velho fornece ao mais novo, que se apresenta enquanto um aspecto carente - toda criança é marcada pelas coisas que não sabe - da entredade. A filiação pressupõe uma diferença entre pais e filhos, no qual o pai é visto como um provedor para os filhos que são, como mostramos anteriormente, seu sêmen corporificado.

Os pais do nomeado tratam nomeador e seu cônjuge pelos termos recíprocos unimelunimeni que se constroem da mesma forma que os tecnonímos. Numa tradução simples, teríamos unime como "pai do nome" e unimeni "mãe do nome", condizente com o que dissemos sobre a raiz uni, porém, uni, enquanto vocativo, indica uma identidade nominal ('meu nome'), assim, teríamos, também, a ideia de pai/mãe do meu nome, o que se apoia tanto no fato de que os pais do receptor são de fato "pais" do uni, quanto pelo fato de ser o nome doado o que nomeia os pais do receptor, em função da tecnonímia. Estas são relações que se multiplicam a partir do estabelecimento da entidade nominal, não sendo marcadas pela semelhança, mas por assimetria recíproca. 
Não seriam propriamente dois seres que compartilham um mesmo nome, mas um ser que se distribuem entre dois corpos.

Os sufixos_me e _meni indicam uma relação semelhante aquela entre pai e/ou mãe e um determinado filho e este é um ponto fundamental, pois não é "pai" ou "mãe" que estes sufixos marcam, mas, necessariamente, "pai de" e/ou "mãe de" alguém determinado. $\mathrm{O}$ uso do sufixo não se restringe a marcação dos que estão implicados no/com o nascimento de alguém. Cônjuges podem ${ }^{295}$ usar entre si os termos durume e durumeni, que se compõem de duru + sufixo_me(ni), mas eles não poderiam ser vistos como "pai/mãe do" duru, pois este termo não indica propriamente uma entidade, e sim uma das regiões corporais de uma pessoa. O duru, região da frente do corpo localizada abaixo da barriga e acima das coxas, é o local em que se origina e onde se sacia o desejo sexual $^{296}$.

O sufixo teria relação com a ideia de pai/mãe, porém ele não tangencia apenas (nossas noções ${ }^{297}$ de) filiação, incluindo também domínio, causação e metonímia. Os unime(ni) estariam em uma relação na qual cada um dos termos se coloca como dominante e dominado pelo outro, isto é, cada um teria uma de suas identidades inscrita e delimitada pelo outro. Mesmo que se tratem de forma recíproca, o que comumente indica simetria e igualdade entre os termos, o tratamento unime(ni) indica um desequilíbrio assimétrico. Uns são pais daquele com quem nomeador passa a compartilhar uni, e o outro é causa (pela tecnonímia) do surgimento de um uni novo nos pais.

A simétria e igualdade ancorada na utilização de termos recíprocos evidencia-se nas formas como se tratam os cunhados e nos vocativos que os Deni aplicam para os não indígenas. Os cunhados sempre se tratam pelo mesmo termo, mesmo que exista grande variação nos vocábulos adotados. Com os não indígenas, que no plano ideal são cunhados/afins, o termo empregado pelo não indígena será sempre reciprocado, exceto

\footnotetext{
${ }^{295}$ Observamos esta forma de tratamento entre casais com muitos filhos, não podemos afirmar que isto também seja válido para casais recém-formados. Observamos alguns maridos usarem apenas meni como vocativo para a esposa.

${ }^{296}$ Nossos dados não permitem explorar esta questão para as mulheres, mas para os homens o duru é a parte da pessoa responsável pelo desejo sexual. Diversas vezes ouvi jovens rapazes e adultos falarem em tom de brincadeira: "uduru [meu duru] pemiaru [esta com fome]", reclamando da falta de sexo.

${ }^{297} \mathrm{Em}$ realidade, no contexto das novas tecnologias de reprodução humana empregadas no ocidente, as noções de maternidade e paternidade têm se alterado a tal ponto (por exemplo, a mãe de alguém podendo ser quem doou um óvulo ou quem gestou o embrião ou quem pagou/recebeu a criança resultante do processo - veja Strathern 2005) que seria complicado afirmar que "pai de" e "mãe de" aqui também seria uma questão de simples filiação.
} 
nos casos em que o kariva utiliza o nome próprio adotado pela pessoa Deni. Em um dos exemplos observados, um senhor de Tapauá chamava um Deni de Zé, e era por ele chamado da mesma forma, tornando-se vocativos recíprocos da relação Zé-Zé. O primeiro impulso dos Deni é chamar o kariva de abuni e, caso este responda de forma recíproca, a relação se manterá na terminologia para cunhados (abuni-abuni) indefinidamente.

A transmissão do nome mistura pessoas e estabelece relações entre aqueles que não seriam, necessariamente, socialmente próximos, dado que, atualmente, parece haver uma tendência a incorporar os nomes dos brancos com quem se estabelece contato, seria de se esperar que, anteriormente, pessoas de outros "subgrupos" fossem tomados como nomeadores preferenciais. Seja como for, as relações criadas pela nomeação se sobrepõem aos (ou surgem no lugar dos) vínculos anteriores, estabelecendo identidades, simetrias e assimetrias, que se desenvolvem de maneira diferente. Os pares uni-uni e unime(ni)-unime(ni) inscrevem devires que os convertem, no limite, em parentesco.

A identidade nominal (uni), semelhança máxima de uma mesma coisa, mas que outros marcam enquanto uma diferença etária ${ }^{298}$, tem seu limite no casamento entre nominado(a) e a(o) filha(o) do(a) nomeador(a), ou o nomeador e a(o) irmã(o) do(a) nomeado(a). Uma (quase) não-relação, baseada na (quase) ausência de oposição (diferença) entre os termos, tem seu limite e fim quando surge propriamente uma relação, na qual se tornam sogro(a)/genro(nora) ou cunhados. De uma semelhança inicial (quase) plena, em que não há termos em relação e sim uma identidade uni distribuída em dois corpos, a única relação possível de emergir é a de afinidade. Sem destoar do panorama amazônico, quando uma identidade é dividida em termos, isto é, quando passa a existir uma relação, esta se situa na afinidade, que constitui o fundo sobre o qual todas as relações se constituem (Viveiros de Castro 2002).

As relações que gravitam ao redor da nominação (unime/unimeni) são inicialmente assimétricas, mesmo que sejam marcadas pela proximidade, há um desequilíbrio fundamental em que uns estão imbricados nas identidades dos outros. Estas relações têm como desenvolvimento possível a manutenção de sua proximidade através da sua conversão em uma simetria entre diferentes, isto é, sua conversão, ou retorno, em a uma relação entre afins, naqueles casos em que nomeador e nominado tornam-se sogros e genros/noras ou cunhados. Os pais de um casal, cuja relação se

\footnotetext{
${ }^{298} \mathrm{O}$ zati e o hurasha que são utilizados pelos outros.
} 
modifica pelo estabelecimento da união matrimonial, vão se situar enquanto cunhados (unime-unime), logo se tornam termos opostos e simétricos em uma relação de parentesco afim. Quando nomeador e nominado tornam-se cunhados, é a sua relação que se torna simétrica, apagando-se a hierarquia etária, tornando a relação entre os unime-unime estabilizada em uma hierarquia sogro-genro. Salientamos, contudo, que podem haver estes casamentos, mas não há qualquer preferência para que aconteçam.

\subsection{Relações de parentesco}

Chamar as relações que agrupamos aqui de parentesco é algo arbitrário, pois elas não corresponderiam nem a uma categoria nativa traduzível por "parentesco", nem poderiam ser abrigadas sob o que nós ${ }^{299}$ consideramos parentesco. Já discutimos a questão dos "parentes" uvibuva nos capítulos 1 e 2. Embora tenhamos dito anteriormente que essa noção corresponderia (e é traduzida pelos próprios indígenas desta forma) a categoria "parente", seu uso, talvez, correspondesse propriamente a consanguíneos, enquanto não-afins. Seus limites de uso seriam os limites do processo do parentesco, logo para os Deni os "afins sem afinidade" (Viveiros de Castro 2002) seriam abarcados por um termo de parentesco, mesmo que não sejam propriamente parentes.

A terminologia de parentesco Deni é uma variante dravidiana concêntrica, em que o binarismo da versão indiana sofre a interferência da distância entre Alter e Ego. Na Amazônia, domínio do dravidiano concêntrico, como Viveiros de Castro (1993, 2002, 2009) já chamou a atenção em diversos momentos, a afinidade fornece o esquema relacional básico sobre o qual se constrói a consanguinidade. Nesse contexto, é possível que algumas destas relações, as de afinidade, sejam dadas e possam, por isso, ser mantidas com entidades ainda desconhecidas do cosmos, enquanto as outras são tidas como construídas ${ }^{300}$ de forma processual, isto é, os vínculos de consanguinidade, que resultam da diminuição da afinidade nas relações.

\footnotetext{
${ }^{299}$ Brasileiros, mas talvez pudéssemos dizer ocidentais euro-americanos (Strathern 2005), pois parente é uma categoria ampla, que inclui pessoas ligadas por laços de filiação e pelo casamento. O termo kinship ('parentesco) na língua inglesa não inclui ou exclui, necessariamente, o casamento e os parentes por afinidade (os in-law), como já mostrou Schneider (1980).

${ }^{300}$ Para uma consideração sobre as três formas como o parentesco tem sido tratado e como a maneira amazônica corresponderia a uma quarta forma veja Viveiros de Castro (2009). Em resumo as diferenças estão em como são consideradas a consanguinidade e a afinidade: a primeira figuraria como natural (dada) e a segunda construída ou; ambas seriam construídas (fenômeno puramente cultural) ou; ambas seriam naturalizadas. Na forma amazônica a afinidade é a relação dada, esquema relacional básico do cosmos, já a consanguinidade é construída, pela extração da afinidade de determinadas relações (Viveiros de Castro 2002).
} 
Como apresentamos no capítulo 1, a semelhança corporal parece ser o limite para o reconhecimento de relações de parentesco. Nesse esquema, os brancos correspondem ao limite, eles são quase-humanos e, portanto, quase-parentes, dai a relação com eles ser recoberta por um termo de parentesco. Os animais, por sua vez, não são nada humanos - e os Deni enfatizam que eles eram, mas deixaram de ser - e, portanto, com eles não há qualquer possibilidade de parentesco. Em certo sentido, o limite estaria colocado na possibilidade de construção de um corpo de parente, pois as almas de animais podem vir a tornarem-se plenamente madiha de nascença.

Para os Deni, isto que chamamos de relações de parentesco estão implicadas na regulamentação da vida sexual. Como mostramos acima, os contatos sexuais impróprios (que transformarão o morto em comida de Hamu) são expressos com estes vocábulos. Estes, também, participam da composição do quadro dentro do qual determinada pessoa situa a si e aos outros no cosmos. Esta visão parece se aproximar das formulações de Héritier (1989), para quem o parentesco é um sistema de relações que unem as pessoas por laços fundados na consanguinidade e na afinidade, que correspondem, respectivamente, às impossibilidades e possibilidades do acesso sexual. Esta aproximação que parece existir (ou que fizemos vir para o primeiro plano) entre determinado conjunto de crenças, surgidas com Morgan (1997 [1871]) e que se desenvolveram em uma noção de parentesco (kinship) que existe apenas na antropologia (Schneider 1984), e o pensamento Deni, não parece diferir daquela que eles próprios fazem ao tornar os brancos inteligíveis com base nesse quadro de relações.

Como já mostramos no capítulo 1, atualmente os kariva são colocados como o entorno do parentesco Deni, eles são tidos como quase humanos, passíveis de serem tornados propriamente humanos, isto é, transformados em parentes. Se, tal como já afirmou Viveiros de Castro (2002), do ponto de vista amazônico, a mesma cultura está em toda parte, os Deni analisam que os brancos, que possuem o mesmo sistema de relações, não as operacionalizam de forma apropriada. O mesmo quadro relacional aplicável a todo e qualquer um dos humanos não é, contudo, vivenciado da mesma forma por todos.

A grande maioria das observações pormenorizada dos comportamentos dos não indígenas e não-Deni datam da época anterior à demarcação da TI Deni. Nos anos recentes, com as constantes idas às cidades, a observação e o relato destas voltaram a acontecer, porém, passaram a ser mais esparsas. Antes, se vivenciava integralmente o 
modo de vida dos extrativistas durante os meses (ou mesmo anos) em que moravam e trabalhavam juntos. Pela observação direta, dizem os Deni que muitos são os brancos que mantinham (ou mantêm) comportamentos não apropriados do ponto de vista do parentesco.

Eles generalizam como norma para todos os kariva que eles não sabem como tratar seus próprios parentes, isto é, não mantêm as relações apropriadas com aqueles que deveriam ser chamados por determinados termos. Nesse sentido, são as relações sexuais com irmãs que surgem comumente nos discursos como prática comum, que faz com que os karivadeni assumam uma perspectiva de presa no post mortem. Além de afirmações sobre alguns casos que seriam incestuosos para nossa própria visão brasileira, haviam alguns em que estavam envolvidos primos paralelos genealogicamente próximos (de primeiro ou segundo grau), condenados segundo o modo do parentesco Deni.

Não parece haver um lugar para os brancos mortos no cosmos Deni, somente quando eram estimulados a pensar sobre o que acontecia com os brancos é que eles eram mencionados: indo para um céu próprio (com Jesus), ou vagando na terra (não têm xamãs para levarem as almas), ou ficando em uma das aldeias da água, ou do céu. Possivelmente os Deni sabem que todos os brancos são/serão comidos por Hamu, mas jamais formularam isto para o antropólogo. Nossa incapacidade para nos adequarmos as normas do parentesco, talvez seja o ponto fundamental a partir do qual se constrói a superioridade Deni sobre todos os brancos, pois, como vimos, do ponto de vista material, eles se situariam num meio termo entre os brancos mais ricos e mais pobres.

São exatamente as mesmas relações de parentesco que os Deni percebem como atuantes entre eles e os brancos, ao ponto de alguns termos do português terem sido incorporados à língua deni. Há uma variação significativa entre a terminologia de referência e a terminologia vocativa, diferença que não se deve tanto a variação nas relações estabelecidas entre as relações de parentesco, mas destas com elementos contingentes. Como apontam Godelier, Trautmann \& Tjon Sie Fat: "Os termos de parentesco, junto com os princípios de classificação e as regras de relacionamento [rules of relationships] que formam os diferentes tipos de terminologia de parentesco, são fatos sociológicos e históricos, criados e aplicados pela mente humana em contextos históricos específicos" (tradução nossa - 1998: 5). Há uma série de termos em português que foram incorporados às formas vocativas Deni, mas não, necessariamente, em substituição aos termos 
nativos, já que, em muitos casos, expressam oposições que anteriormente não possuíam vocábulos fixados.

\section{A terminologia de referência}

Tomemos a terminologia de referência como ponto de partida, pois ela corresponde a uma espécie de quadro conceitual utilizado por todo e cada um dos humanos. Entre os Deni, as relações aparecem nomeadas de três maneiras na forma referencial: há os meus parentes, com quem tenho determinada relação (possuídos na $1^{\text {a }}$ pessoa), os seus (possuídos na $2^{\mathrm{a}}$ pessoa) e os dele (sem marcação de posse). A única diferença entre as três parece ser que, quando se fala da(o/s) irmã $(\mathrm{o} / \mathrm{s})$ dele, não há a marcação da idade relativa, ou seja, não parece haver termos para diferenciar os irmãos mais velhos e os mais novos de alguém.

Em alguns momentos, as relações são opostas entre si como, por exemplo, quando dizem que não devem ter relações sexuais com ukharipene e uhirumadini, devendo tê-las apenas com uvini, mas não se delimita o sistema total. Claro que, no curso de conversas e questionamentos, surgem reflexões mais sistemáticas sobre o conjunto das relações de parentesco. Mesmo que não apareça comumente enquanto um sistema, o conjunto desses vínculos é visto como sendo possuído por cada um dos humanos. Não é necessário que alguém tenha todos os vínculos para que suas relações sejam delineadas da mesma forma que as dos outros.

A versão da terminológica que construímos em campo difere sensivelmente daquela que analisamos em outros trabalhos (Florido 2008, 2011) e que se baseava nos dados fornecidos por Koop \& Lingenfelter (1983). A grande diferença diz respeito à manutenção da distinção entre consanguíneos e afins nas gerações distais ( $\mathrm{G}+2$ e G-2), que não é apresentada por estes autores. Tal característica não é trivial, como iremos mostrar posteriormente, pois torna o sistema cíclico, gerando e reforçando uma identidade entre as gerações alternas.

As oposições básicas da terminologia Deni podem ser vistas quando os termos são dispostos na grade dravidiana, que torna evidente os princípios atuantes em cada categoria. Representamos a terminologia na forma tradicional da grade, porém nem todos os parâmetros se realizam da forma como ela é comumente apresentada. A noção de geração não é muito relevante, embora seu princípio constitutivo influencie a 
determinação dos limites das categorias, isto é, os vínculos genealogicamente próximos que são incluídos em cada classe, para os distantes é a idade, e não a filiação, a força classificatória mais relevante.

Figura 5 - Terminologia de referência Deni Ego Masculino

\begin{tabular}{|c|c|c|c|c|c|}
\hline \multirow{3}{*}{$\mathrm{G}+2$} & & \multicolumn{2}{|c|}{$0^{\lambda}$} & \multicolumn{2}{|r|}{ q } \\
\hline & & afim & \multicolumn{2}{|c|}{ consanguíneo } & afim \\
\hline & & $\begin{array}{c}\text { FMB, MMB } \\
\text { abuni WFF WMF }\end{array}$ & $\begin{array}{l}\text { ukhatuvi } \\
\text { FF MF }\end{array}$ & $\begin{array}{l}\text { ukhatizu } \\
\text { FM MM }\end{array}$ & $\begin{array}{c}\text { FFZ MFZ } \\
\text { uvini WFM WMM }\end{array}$ \\
\hline \multicolumn{2}{|l|}{$\mathrm{G}+1$} & $\begin{array}{c}\text { kuku } \\
\text { MB WF HF }\end{array}$ & $\begin{array}{l}\text { ukhabi } \\
\text { F FB }\end{array}$ & $\begin{array}{l}\text { ukhami } \\
\text { M MZ }\end{array}$ & $\begin{array}{c}\text { ukhashu } \\
\text { FZ WM HM }\end{array}$ \\
\hline \multirow{2}{*}{$\begin{array}{l}\text { G0 } \\
301\end{array}$} & e & \multirow{2}{*}{$\begin{array}{c}\text { abuni } \\
\text { FZS MBS ZH }\end{array}$} & ukhazu eB $\mathrm{eB}^{302}$ & ukhadi eZ & \multirow{2}{*}{$\begin{array}{c}\text { uvini } \\
\text { FZD MBD WZ } \\
\text { upanadi W }\end{array}$} \\
\hline & $y$ & & ukhakabu yB & ukharipene yZ & \\
\hline \multicolumn{2}{|l|}{ G-1 } & $\begin{array}{l}\text { uhirubadi } \\
\text { ZS DH }\end{array}$ & $\begin{array}{c}\text { ukhadau } \\
\text { BS }\end{array}$ & $\begin{array}{c}\text { ukhatu } \\
\text { BD }\end{array}$ & $\begin{array}{l}\text { uhirumadini } \\
\text { ZD SW }\end{array}$ \\
\hline \multicolumn{2}{|l|}{ G-2 } & abuni ZChS & \multicolumn{2}{|c|}{ uhinudini $\mathrm{ChCh}$} & uvini $\mathrm{ZChD}$ \\
\hline
\end{tabular}

Figura 6 - Terminologia de referência Deni Ego Feminino

\begin{tabular}{|c|c|c|c|c|c|}
\hline & \multicolumn{2}{|c|}{$\hat{0}$} & \multicolumn{2}{|r|}{ q } \\
\hline & & afim & \multicolumn{2}{|c|}{ consanguíneo } & afim \\
\hline \multicolumn{2}{|l|}{$\mathrm{G}+2$} & $\begin{array}{c}\text { FMB, MMB } \\
\text { uvini HFF HMF }\end{array}$ & $\begin{array}{l}\text { ukhatuvi } \\
\text { FF MF }\end{array}$ & $\begin{array}{l}\text { ukhatizu } \\
\text { FM MM }\end{array}$ & $\begin{array}{c}\text { FFZ MFZ } \\
\text { ukharadi } \\
\text { HFM HMM }\end{array}$ \\
\hline \multicolumn{2}{|l|}{$\mathrm{G}+1$} & $\begin{array}{c}\text { kuku } \\
\text { MB WF HF }\end{array}$ & $\begin{array}{l}\text { ukhabi } \\
\text { F FB }\end{array}$ & $\begin{array}{l}\text { ukhami } \\
\text { M MZ }\end{array}$ & $\begin{array}{c}\text { ukhashu } \\
\text { FZ WM HM }\end{array}$ \\
\hline \multirow[t]{2}{*}{ G0 } & $\mathrm{e}$ & \multirow{2}{*}{$\begin{array}{c}\text { uvini } \\
\text { FZS MBS HB } \\
\text { ukha makhi H }\end{array}$} & ukhazu eB & ukhadi eZ & \multirow[t]{2}{*}{$\begin{array}{c}\text { ukharadi } \\
\text { FZD MBD BW }\end{array}$} \\
\hline & $\mathrm{y}$ & & ukhakabu yB & ukharipene yZ & \\
\hline \multicolumn{2}{|l|}{ G-1 } & uhirubadi BS DH & ukhadau ZS & Ukhatu ZD & uhirumadini BD SW \\
\hline \multicolumn{2}{|l|}{ G-2 } & uvini $\mathrm{BChS}$ & \multicolumn{2}{|c|}{ uhinudini $\mathrm{ChCh}$} & ukharadi BChD \\
\hline
\end{tabular}

\footnotetext{
${ }^{301}$ No processo de investigação sobre o vinculo de parentesco com determinadas pessoas, algumas vezes surgiram as expressões $u k h a$ ['meu' - possessivo $1^{\text {a }}$. pessoa singular] abuni, ukhavini, ukha kuku; porém as formas que escolhemos surgiam mais comumente como termos de referência para afins.

${ }^{302}$ A única diferença entre a terminologia possuídas na $1^{\mathrm{a}}$. pessoa (que fornecemos), $2^{\mathrm{a}}$ e $3^{\mathrm{a}}$. ocorre nesta linha. A terminologia na $3^{\mathrm{a}}$. pessoa não faz distinção entre os consanguíneos mais velhos e mais novos nesta geração. Há apenas irmão dele/a (uvaa) e irmã dele/a (unii), a idade relativa não sendo marcada terminologicamente.
} 
A estrutura terminológica é de base dravidiana, mas mantém a distinção entre consanguíneos e afins em G+2 e G-2, de uma forma semelhante a que realizam os Kulina descritos por Lorrain (1994). Gordon (2006) aproxima a terminologia Kulina desta autora do dravidiano modelo B, descrito por Trautmann (1981), que seria, segundo ele, caracterizado pela manutenção da distinção entre paralelos e afins nas gerações distais $\left(\mathrm{G}+2\right.$ e $\left.\mathrm{G}-2^{303}\right)$. Este não parece ser o caso, pois, tal como a terminologia Deni, os Kulina estabelecem relações distintas do modelo B, ou mesmo do modelo C, parecendo corresponder a um quarto modelo, que estaria próximo do modelo A.

Trautmann (1981) estabelece que o modelo A do dravidiano não apresenta a distinção entre parentes paralelos e cruzados em G+2 e G-2, havendo, quando muito, classes que levam em conta a diferença sexual. Ele observa que há casos em que terminologias dravidianas apresentam outras distinções nestas gerações, que, a seu ver, poderiam ser de dois tipos e que corresponderiam aos modelos B e C. O modelo B manteria diferenças nas gerações distais com base no paralelismo e cruzamento, já o modelo $\mathrm{C}$ apresentaria diferenças de lado.

Como aponta Trautmann (1981:191), o modelo B apresenta as seguintes oposições:

\begin{tabular}{|c|c|c|}
\hline $\mathrm{FF}+\mathrm{MM}$ & vs. & $\mathrm{MF}+\mathrm{FM}$ \\
\hline${ }^{\lambda} \mathrm{SCh}+{ }_{+} \mathrm{DCh}$ & & o SCh $+{ }^{\lambda} \mathrm{DCh}$ \\
\hline
\end{tabular}

A manutenção do paralelismo e cruzamento se processa, aqui, de forma que a mudança de sexo entre as gerações transforma os ascendentes e descendentes em parentes cruzados. A oposição que se estabelece em G+2 e G-2 está baseada em um princípio que distingue relações de filiação entre pessoas de mesmo sexo e de sexo oposto.

\footnotetext{
303 Todas as determinações genealógicas destas categorias são complicadas, pois dependem da não ocorrência de outros vínculos. O casamento de primos cruzados é um evento que impossibilita a existência desta distinção, pois leva, por exemplo, a identidade entre FFZ=MM=WFM, sendo sua ausência o que torna possível que WFM seja uma uvini. Nas gerações posteriores, por exemplo, para Ego masculino, uma ZSD também é uvini apenas nos casos em que ela não corresponde a DD, isto é, quando D não casou com ZS, não houve um casamento de primos cruzados.
} 
No modelo B, a lógica de cruzamento para as gerações distais faz com que ocorra a identidade entre alguns parentes afins e os paralelos, como pode ser visto abaixo, que toma o ponto de vista de Ego masculino.

\begin{tabular}{|c|c|}
\hline Parentes Paralelos & FF, MM, WMF, WFM \\
\hline Parentes Cruzados & MF, FM, WFF, WMM \\
\hline
\end{tabular}

Ao aplicar aos ascendentes do cônjuge a mesma lógica atuante entre os próprios ascendentes, os parentes cruzados de $\mathrm{G}+2$ do cônjuge tornam-se parentes paralelos. Estas equivalências não correspondem ao que se encontra nos contextos Deni e Kulina, em que os próprios ascendentes não se confundem com os ascendentes dos cônjuges.

O modelo C de Trautmann (1981) apresenta equivalências em que o cruzamento não é aplicado nas gerações distais, sendo substituído por uma distinção de lado. Há distinções entre os parentes do pai e os parentes da mãe, tal como entre os filhos do filho e os da filha. O conjunto assim se organiza:

$\begin{array}{ccc}\mathrm{FF}+\mathrm{FM} & \text { vs. } & \frac{\mathrm{MF}+\mathrm{MM}}{\mathrm{DS}+\mathrm{SD}}+\mathrm{DD}\end{array}$

A sua estrutura não depende da relação de filiação ocorrer entre pessoas de mesmo sexo ou de sexo oposto, mas, sim, do sexo do parente de ligação imediato. As relações que partem de homens (F ou $\mathrm{S}$ ) formam categorias que se opõem àquelas que partem das mulheres (M ou D).

Nenhum destes dois modelos corresponderia aos casos Deni e Kulina que apresentam algumas equivalências que contrariam os modelos B e C. Nestes contextos estão presentes as equações: 


$$
\begin{gathered}
\mathrm{FF}=\mathrm{MF} \neq \mathrm{FMB}=\mathrm{MMB}=\mathrm{WFF}=\mathrm{WMF} \\
\mathrm{FM}=\mathrm{MM} \neq \mathrm{FFZ}=\mathrm{MFZ}=\mathrm{WFM}=\mathrm{WMM}
\end{gathered}
$$

Estas equivalências entre certas posições cruzadas e algumas afins apontam para uma relação destas terminologias com o modelo dravidiano A. Como chama a atenção Viveiros de Castro, esta equação mostra que o estatuto cruzado de MMB e FFZ segue a lógica de cruzamento do modelo A, pois seriam paralelos no modelo B. A questão que se coloca, contudo, é que, “o caráter 'cruzado' destes kin types não se realiza terminologicamente no modelo $\mathrm{A}$, onde $\mathrm{MMB}=\mathrm{FF}=\mathrm{MF}$ e $\mathrm{FFZ}=\mathrm{MM}=\mathrm{FM}$ " (1996: 4142), o que reflete o casamento de primos cruzados.

As determinações genealógicas das categorias afins de G+2 e G-2 entre os Deni e os Kulina são complicadas, pois dependem da não ocorrência de outros vínculos. $\mathrm{O}$ casamento de primos cruzados é um evento que impossibilita a existência desta distinção, pois leva, por exemplo, a identidade entre $\mathrm{FFZ}=\mathrm{MM}=\mathrm{WFM}$, sendo sua ausência o que torna possível que WFM seja uma uvini. Nas gerações descendentes, por exemplo, para Ego masculino, uma ZSD é uma uvini somente nos casos em que ela não corresponde a $\mathrm{DD}$, isto é, quando $\mathrm{D}$ não casou com $\mathrm{ZS}$, não houve um casamento de primos cruzados.

Lorrain (1994) aponta que, entre os Kulina, os casamentos entre primos cruzados genealógicos são raros e não desejáveis, isto faz com que não ocorram essas identificações de fato, logo, a expressão terminológica dos cruzamentos em G+2 e G-2, de uma maneira condizente com o dravidiano $\mathrm{A}$, estaria relacionada com a não realização de casamentos que causariam a identificação de posições que impediriam a expressão do caráter cruzado de certas tipos de parentes. Entre os Deni, isto também seria válido, pois, embora existam, o casamento entre primos de primeiro grau é menos frequente do que aqueles entre primos de segundo ou terceiro graus. Não acreditamos, contudo, que este seja realmente o caso.

Lorrain, para justificar a manutenção das distinções na terminologia Kulina, afirma que a "relação de afinidade ou consanguinidade real prevalece sobre as classificatórias" (1994: 140), querendo dizer com isto que a realização terminológica do cruzamento em G+2 e G-2 ocorreria porque as equivalências não existem. Este não parece ser o ponto, porque a identidade real entre as posições podem vir a ocorrer. A 
questão parece estar ancorada em outro princípio que não as distinções entre parentes reais e classificatórios, que pressupõem a existência de certas posições que definem os sentidos das categorias e de regras de extensão.

Os Deni parecem estabelecer uma distinção em G+2 e G-2 que parte da oposição entre parentes lineares e colaterais paralelos e os afins e/ou cruzados. As distinções concêntricas comuns ao dravidiano amazônico ganham expressão terminológica entre os Deni e Kulina. Os casamentos com afins/cruzados que estariam em G+2 ou G-2 realizam torções que só respeitam a lógica da linearidade. O exame da rede genealógica no próximo capítulo tornará isto claro, pois os casamentos com parentes lineares são inexistentes, mas ocorrem com cruzados e colaterais distantes. $\mathrm{O}$ cruzamento dravidiano interno a cada uma das gerações torna-se relevante na medida em que se realizam a partir de um parente linear.

Como toda terminologia, a dos Deni "codifica um certo padrão de repetição de alianças previamente estabelecidas por parentes" (Viveiros de Castro 1996: 35), que, neste contexto, está relacionado com a existência de um cálculo de cruzamento dravidiano, decorrente da regra de casamento de primos cruzados. $\mathrm{O}$ casamento, em realidade, ocorre com pessoas de certa categoria, na qual estão incluídos os primos cruzados e outras pessoas que são parentes genealogicamente cruzados no cálculo dravidiano. A determinação dos primos cruzados enquanto cônjuges potenciais, isto é, a definição dos parentes cruzados enquanto afins, não indica que há uma confusão entre genealogia e categoria.

Estas são dimensões distintas e devem ser consideradas enquanto tal, já que a categoria esta no domínio semântico do parentesco enquanto a genealogia corresponde à prática. Como apontou Needham (1973), o parentesco apresenta três níveis analíticos distintos: o categorial (ou semântico), que corresponde ao vocabulário da terminologia e sobre o qual nos detemos neste momento; o jural (ou normativo) que, para este autor, indicaria direitos e deveres entre as pessoas, mas que acreditamos seria melhor entendido como a forma ideal da relação; e o comportamental (ou prático), que corresponde ao desenvolvimento das normas no plano empírico, ou seja, corresponde a vivência do modelo ideal nativo.

Como chama a atenção Viveiros de Castro 
“o isomorfismo entre a oposição categorial consanguíneo/afim e a oposição genealógica paralelo/cruzado não deve ser vista como exprimindo uma identidade essencial, e normativamente definidora do tipo dravidiano, mas como um caso-limite de uma relação mais complexa que pode 'derivar' em diversas direções, sem que isto signifique uma absoluta autonomia entre os dois pares conceituais". (grifo do autor 1996: 33).

Num universo onde todos os humanos são parentes, isto é, onde figuram como termos de uma relação de afinidade ou consanguinidade, há momentos em que a padronização semântica e as ligações traçáveis coincidem.

Devemos salientar que, entre os Deni, os únicos que jamais são parentes, ou seja, nunca são humanos, são os animais. Eles deixaram de ser humanos e, enquanto animais, não podem ser parentes. Isto fica evidente, entre outros momentos já mencionados, quando consideramos os animais de criação e as pessoas adotadas (órfãos), entre os quais há uma diferença irredutível. Animais de criação são meze, já crianças criadas são meze bute, sendo bute um termo que indica ora incompletude, ora finalização há muito tempo. O dicionário de Koop \& Koop fornece duas entradas, enquanto sufixo verbal e enquanto adjetivo, para bute: “_bute 1 (suf. v.) quase. 2 (suf. v., term. v. ) aspecto completo. Bute (adj. 2g.) velho (que não presta mais; não é mais usado)" (1985: 52).

Alguns vínculos genealógicos são (quase) sempre de uma ou outra categoria, são casos limites, mas não são seus definidores. A identidade entre as gerações alternas, particularmente evidente no caso dos afins de G+2, G0 e G-2, mostra que nada autoriza tomarmos algumas posições genealógicas como mais básicas, ou como definidoras das classes. Seja pela consideração de que, muito provavelmente, as pessoas que seriam genealogicamente situadas em $\mathrm{G}+2$ nasceram antes que aquelas em G0, seja pela falta de um sentido primário de algumas posições genealógicas que participam da classe, tal como seriam os "primos cruzados" que participam desta categoria; a relação se assenta em outras bases. Não devemos, contudo, considerar os afins destas gerações de forma isolada, pois o relevante são as relações.

No plano semântico, a organização das relações de afinidade em gerações não faz justiça a sua lógica estrutural. Há dois tipos de relação, aquelas que são simétricas, e envolvem termos equivalentes, e as assimétricas, nas quais Ego e Alter não são equivalentes, mudando o sentido conforme se situam em um ou outro dos polos. Neste 
último caso eles são referidos de forma diferente, em que vai depender do ponto de vista que se toma, isto é, da posição em que Ego esta sendo fixado. Os pares relacionais no plano da afinidade são:
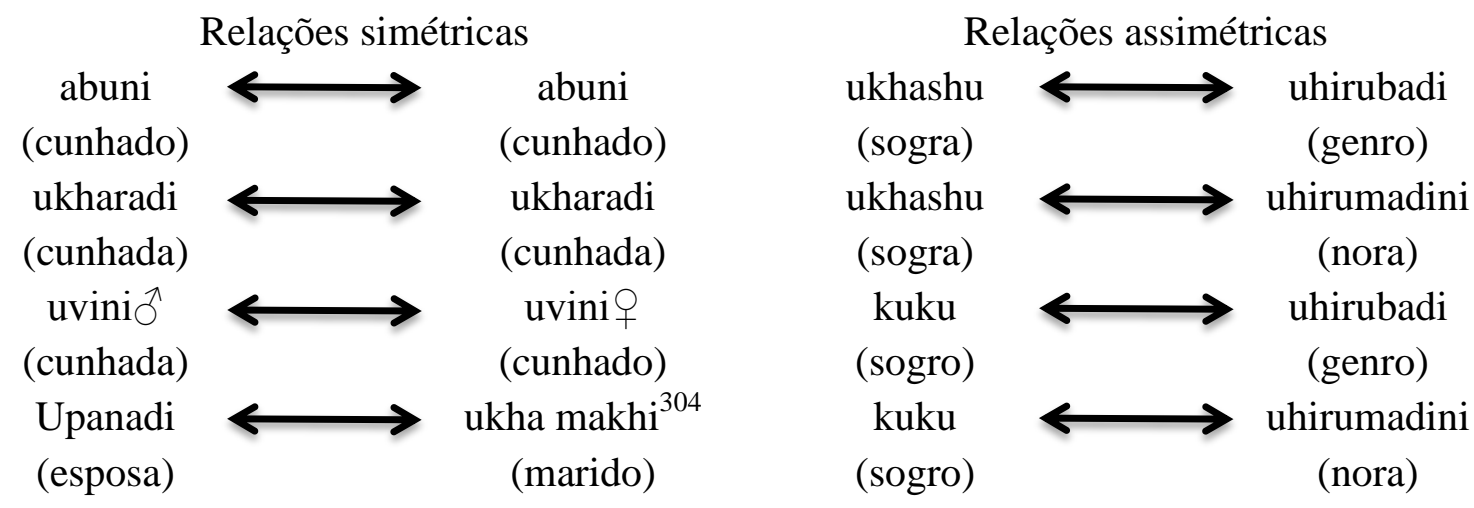

É interessante notar que as relações sexuais só podem ocorrer entre os afins que mantêm relações simétricas, isto é, entre termos intercambiáveis que mantêm o mesmo vínculo sem importar onde seja fixado Ego. Dentre as pessoas de sexo oposto que se encontram nesta condição deve ocorrer o matrimônio, isto é, este deve ser realizado entre aqueles são referidos como uvini. Este evento fixa algumas pessoas em uma das outras duas categorias de afins assimétricos, ou seja, somente a união matrimonial entre dois uvini faz com que determinada pessoa seja fixada invariavelmente como kuku/ukhashu ou uhirubadi/uhirumadini.

Embora haja termos diferentes para os afins em $\mathrm{G}+1$ e G-1, as relações são intercambiáveis, estando em dependência da história. Não são, apenas, os termos de uma mesma relação, mas possibilidades de categorização de qualquer dado Alter, com o qual Ego não deve ter relações sexuais e/ou matrimoniais, mas seus consanguíneos de gerações adjacentes podem. Os afins se alternam indefinidamente entre aqueles com quem Ego pode e não pode ter relações sexuais, ou seja, há aqueles que a própria pessoa pode vir a tomar como cônjuge e os que estão reservados para seus consanguíneos de outra geração.

\footnotetext{
${ }^{304}$ Os termos envolvidos na relação conjugal são os únicos não recíprocos e esta é a relação em que o processo de consanguinização dos afins efetivos mais se faz presente e talvez resida nisso a não simetria da forma referencial. Todas as relações consanguíneas são marcadas pelo uso de termos não recíprocos.
} 


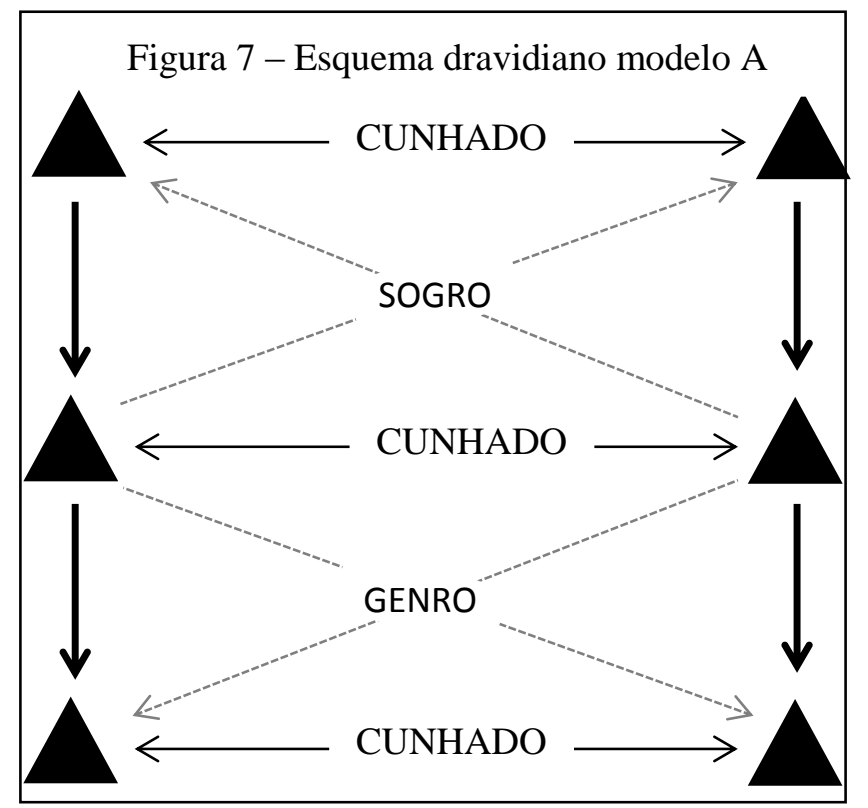

Se focarmos a relação de afinidade entre os homens, vemos que, na ausência da distinção consanguíneos e afins em G+ 2 e G2 e da equivalência entre as gerações alternas, forma-se um esquema (como mostrado no desenho ao lado $^{305}$ ) em que a relação de afinidade em dada geração será reproduzida entre os descendentes diretos. Os afins do pai $(\mathrm{G}+1)$ e dos filhos $(\mathrm{G}-1)$ formam categorias diferentes, pois são pais do cunhado $(\mathrm{G}+1)$ e filhos do cunhado (G-1), sendo mantida na afinidade a hierarquia geracional da consanguinidade. Ascendentes e descendentes são marcados de forma diferenciada, garantindo que haja a classe dos que podem casar com Ego, aquela em que casam seus ascendentes e uma terceira em que casam seus descendentes.

A terminologia Deni, ao manter a distinção consanguíneos e afins entre as pessoas

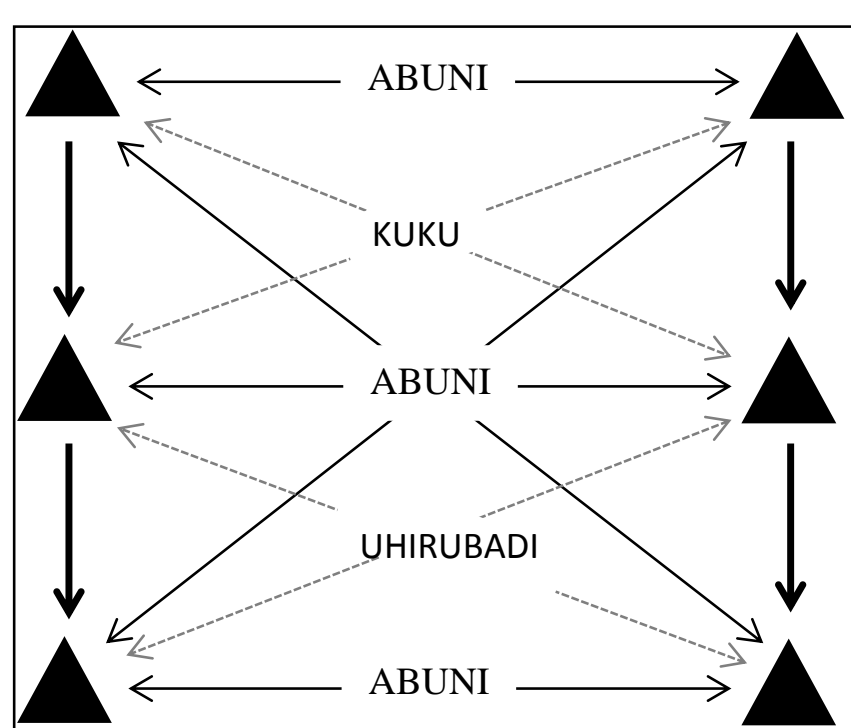

Figura 8 - Esquema Deni que se situariam em $\mathrm{G}+2$ e G-2, fundindo elas nas categorias de G0, torna a estrutura plenamente cíclica. Não há uma classe de afins para Ego, outra para seus consanguíneos de G+1 e uma terceira para aqueles de G-1. Não há uma rigidez previa entre quais pessoas (ou kin types) ocupam determinada categoria, embora a idade relativa pareça ser um fator considerado inicialmente. Para qualquer pessoa, o pai de seu abuni (consanguíneos de G+1 de um afim), embora seja abuni de seu próprio pai (consanguíneo de G+1), não é necessariamente um afim de

\footnotetext{
${ }^{305} \mathrm{O}$ esquema representa as três gerações medianas, sendo que as linhas verticais não nomeadas indicam ligações consanguíneas intergeracionais, que neste caso corresponde a mudança de geração.
} 
G+1 (pai/mãe de cunhado/cônjuge), podendo ser um afim de G-1, isto é, um abuni de seu filho, que pode vir a se tornar cônjuge dos filhos desta pessoa. É impossível se falar aqui de uma transmissão dos vínculos de afinidade, mas, sim, de uma alternância em que cada geração enxerga os afins de um dentre dois modos possíveis e excludentes, enquanto possíveis parceiros sexuais e cônjuges, ou enquanto interditos, sendo que os interditos são aqueles que são permitidos aos consanguíneos de gerações adjacentes.

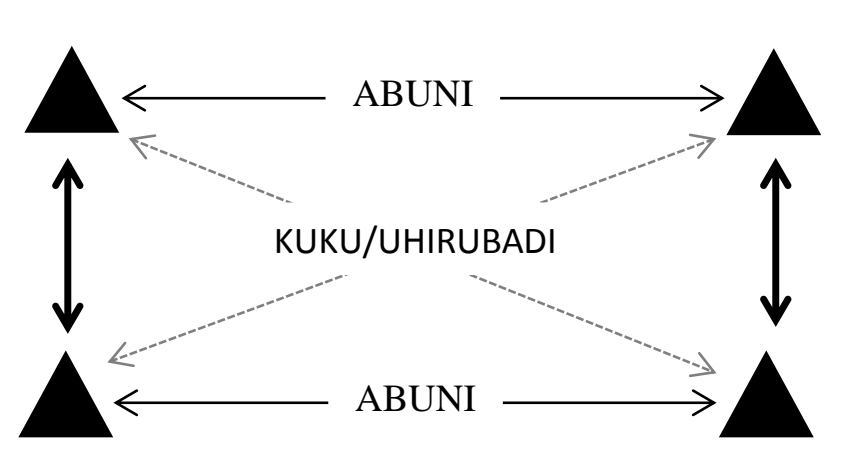

Figura 9 - Modelo classificatório

Todo afim interdito para dado Ego pode, virtualmente, ser $k u k u$ ou uhirubadi, mas, sempre se estabelece o par recíproco. Embora a princípio Alter possa assumir qualquer um dos polos, após ele ser fixado, Ego vai se situar no polo aposto da relação. A história e o jogo político matrimonial é que vão determinar qual será a classificação de determinado indivíduo, se ele será um genro/nora (uhirubadi/uhirumadini), isto é, cônjuge potencial dos filhos de Ego ou; se será um sogro/sogra (kuku/ukhashu) com cujos filhos Ego terá relações sexuais e/ou matrimoniais.

A variação nas classificações dos afins é evidente nos casos em que ocorrem relações sexuais entre dada pessoa e os filhos de seu uhirubadi/uhirumadini. Este comportamento deve ocorrer com os filhos de kuku/ukhashu, mas se a relação não se torna de amplo conhecimento (ou não é reconhecida pelo casal que não pretendem se unir matrimonialmente) os polos se mantêm inalterados. São cálculos políticos que fazem com que se assuma uma ou outra posição, isto é, que alguém se coloque como genro ou sogro de outra pessoa.

Nas categorias de consanguíneos, a identidade entre as gerações alternadas não ocorre de forma tão evidente, principalmente entre os lineares. Há cinco classes consanguíneas que se organizam com base na diferença sexual (só uma das classes não faz esta distinção) e idade relativa/geração. A hierarquia etária/geracional parece ser um princípio irredutível, pois a classificação de consanguíneos (genealogicamente) distantes em G+1 ou G-1 depende da idade em relação a dado Ego, o que acaba resultando em conjuntos de germanos que se relacionam de forma muito diversa, ou 
seja, a unidade do grupo de siblings afirmada por Radcliffe-Brown (1998[1941], 1967[1950]) não é um princípio relevante na cosmologia Deni.

No domínio da consanguinidade não há relações simétricas, os polos ocupados por Alter e Ego determinam sempre diferenças comportamentais. Os vínculos consanguíneos, ao contrário dos assimétricos de afinidade, não são reversíveis, sendo hierarquizados de acordo com a idade relativa ${ }^{306}$. Este parâmetro, embora exerça certa influência na afinidade, é mais relevante entre os consanguíneos. A noção de geração, tal como seria concebida entre nós, parece ser aplicável apenas para aqueles genealogicamente próximos, pois, entre os distantes, é a idade relativa que determina qual polo da relação intergeracional será ocupado por Ego e Alter.

Não é possível determinar, precisamente, qual relação será estabelecida entre quaisquer duas pessoas, exceto nos casos em que são próximas, com base exclusivamente no cálculo genealógico. Não queremos dizer com isto que tudo é válido, mas, apenas, que a distância é um componente relevante na delimitação das categorias, pois certas posições podem estar presentes em muitas delas. A organização da terminologia esta baseada na divisão consanguíneos e afins, que esta relacionada com um cálculo de cruzamento (de definição genealógica da afinidade) dravidiano, a possibilidade de realização de casamentos de primos cruzados, e a idade relativa.

Os pares relacionais consanguíneos são os seguintes:

\footnotetext{
${ }^{306}$ Pollock (1985a) aponta que entre os Kulina a idade relativa, mais do que a genealogia, seria relevante para a classificação de certas pessoas, mas indica a relevância apenas no que diz respeito aos matrimônios que ocorrem entre pessoas de idade aproximada. No caso Deni não é disso que se trata, pois o matrimônio pode ocorrer entre pessoas com grandes diferenças etárias. Não são raros os casos de segundos casamentos em que um dos cônjuges (o marido ou a esposa) tenha filhos (ou mesmo netos) mais velhos que seu novo parceiro.
} 


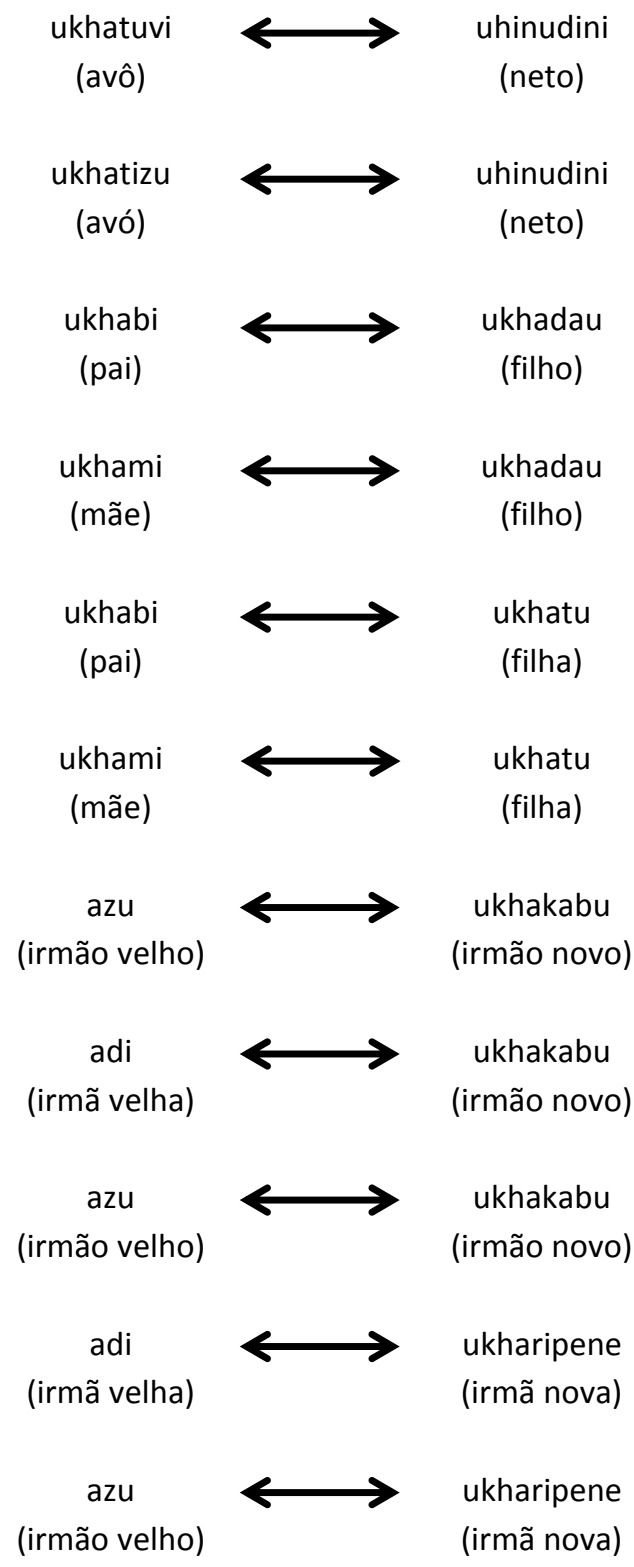

Os termos a esquerda correspondem ao polo mais velho da relação e os a direita ao mais novo. Ele indica a forma como cada um dos termos da relação classifica o seu oposto, isto é, correspondem aos pares de recíprocos presentes na terminologia.

Os termos ukhatuvi, ukhatizu, uhinudini são aqueles que apresentam menores possibilidades de aplicação, estando restritos a determinados vínculos genealógicos. Estas relações envolvem posições restritas e irreversíveis, que escapam de uma determinação matrimonial. Dada a existência do casamento de primos cruzados enquanto norma, os cônjuges podem partilhar os mesmos avôs e estes verão seus descendentes consanguíneos casarem entre si. A questão parece ser que estes pares 
distais marcam o desenvolvimento linear e não cíclico da consanguinidade, que corresponde ao cerne da existência dos uvibuva ("parentes") e que fornece a ligação entre o tempo atual e o tempo dos antigos ${ }^{307}$. Os netos veem seus avós como os depositários do conhecimento e seus transmissores legítimos, enquanto que os avós apreendem os netos como representantes da carência e falta de conhecimento ${ }^{308}$.

Ukhatuvi e ukhatizu correspondem a FF, MF e FM, MM, respectivamente. A partir das informações de Koop \& Lingenfelter (1983) é possível estipular um limite para a aplicação destes termos, já que segundo afirmam $\mathrm{FF}=\mathrm{FFB} \neq \mathrm{FFFBS}$, ou seja, os irmãos de mesmo sexo de ukhatuvi e ukhatizu seriam inclusos na categoria, mas seus primos paralelos seriam excluídos e transformados em afins simétricos. Não podemos confirmar que isto aconteça sempre assim, pois não foi possível aprofundar a investigação neste sentido. Há casos em que um FFFBS entra na categoria dos afins, mas não é possível afirmar que este seja o vinculo genealógico relevante, pois as mesmas pessoas eram FF, MF de um afim. O que observamos é que o polo complementar, o uhinudini corresponde aos $\mathrm{ChCh}$ e seus descendentes (ChChCh, $\mathrm{ChChChCh}^{309} \ldots$ ), neutralizando qualquer possibilidade de alternância das gerações consanguíneas lineares.

A questão se complica, pois as formas vocativas dessas categorias (atuvi e atizu) podem ser aplicadas a quaisquer pessoas muito velhas, respeitando apenas a diferença sexual. As equivalências estabelecidas entre os consanguíneos lineares de gerações ascendentes consecutivas $(\mathrm{G}+2=\mathrm{G}+3=\mathrm{G}+4 \ldots)$ e as pessoas de idade muito avançada parece reforçar a noção de que eles funcionam como intermediários entre o tempo dos antigos e os tempos atuais. Como já apontamos anteriormente, apenas as pessoas que podem ser situadas no polo sênior desta relação são consideradas plenamente adultas, isto é, são tidas como possuindo os conhecimentos mínimos para serem ouvidas e respeitadas pelos outros.

No plano referencial, a separação entre a consanguinidade linear e colateral está inscrita na existência de categorias consanguíneas em G+2 e G-2 e que são estendidas indefinidamente para os parentes lineares de $\mathrm{G}+3, \mathrm{G}+4, \mathrm{G}+5 \ldots$ e $\mathrm{G}-3, \mathrm{G}-4, \mathrm{G}-5 \ldots$ A

\footnotetext{
${ }^{307}$ Veja o capítulo 1.

${ }^{308}$ Talvez resida nisso a não marcação da diferença sexual entre os netos. São muito raros os casos em que determinada pessoa esteja viva quando seus netos tornam-se avós, isto é, passaram a ser reconhecidos como conhecedores de algo.

${ }^{309}$ O limite da observação direta em campo foi uma senhora que apontava DDDS como uhinudini.
} 
distinção de algumas pessoas que estariam virtualmente (essa noção não é aplicável ${ }^{310}$ ) nestas gerações como afins, torna possível a distinção de alguns lineares como claramente parentes (uvibuva) em um eixo temporal não cíclico, separados dos consanguíneos colaterais e das linhas de afins que são cíclicas. Diferente do que ocorre entre os Jarawara, que, segundo Maizza, têm os "avós", categoria utilizada também para todos os velhos, e os "netos", como ambíguos que "podem se apresentar ora como consanguíneos protetores, ora como afins e mesmo como meta-afins" (2012: 125), há, entre os Deni, uma distinção nítida entre os afins e os ascendentes dos consanguíneos de G+1 (ukhami e ukhabi) de Ego.

A princípio, poderíamos afirmar, tal como faz Lorrain (1994) para os Kulina, que os afins de G+2 são os "avós" dos cônjuges de G0, excetuando-se os casos em que se trate de casamento de primos cruzados genealógicos de primeiro grau. Há, contudo, uma diferença fundamental, enquanto que, segundo esta autora, para os Kulina, a identidade entre as gerações alternas é reforçada pela regra de transmissão de nomes pessoais (de “avós” para “netos”), entre os Deni (sem um ciclo de transmissão nominal semelhante), parece que a questão é, como já dissemos, que no plano da afinidade as relações de filiação correspondem a uma mudança quanto a possibilidade e impossibilidade de relações sexuais. Há, claramente, uma distinção entre "Nós" e "Eles" fixada na terminologia, que expressa o modo Deni de estar no mundo, no qual se concebe um "Nós" (os parentes - uvibuva) que perdura temporalmente em contato com "Eles"311 (as Alteridades). Talvez seja esta lógica que torna desnecessário o surgimento de uma distinção vocabular do tipo "Nós" e "Eles/não-Nós" que apontamos no capítulo 1.

Se considerarmos a onomástica Deni, vemos que, embora não seja uma norma como entre os Kulina, os avôs são os únicos consanguíneos lineares que podem transmitir, pois os pais só podem doar, seus nomes para os filhos. Esta característica

\footnotetext{
${ }^{310}$ A mesma inexistência da noção de gerações na terminologia é vista entre os Kulina. Eles apresentam a distinção entre consanguíneos e afins em G+2 e G-2, que, segundo Lorrain, seriam distinguidas dos ohuini (cognato do uvini deni) de G0 pelo acréscimos de jadahui (m) ou jadani (f) em G+2 e do sufixo dsati para G-2, que significariam, respectivamente, old potencial spouse (cônjuge potencial velho) e young potential spouse (cônjuge potencial novo). Nossos conhecimentos sobre a língua kulina são limitados, mas se os adjetivos jadahuiljadani ("JADA (a) - velho, maduro" - Silva \& Monserrat 1984) e dsati ("DSATI (a) - novo, verde, recente" - Silva \& Monserrat 1984) forem semelhantes ao par Hurasha - Zati dos Deni, eles não possuem relação com uma marcação genealógica. Em deni, eles indicam uma diferença de idade relativa (ou, no caso de objetos, uma anterioridade temporal) que não é, necessariamente, muito grande. Um homem que se casa com duas irmãs (filhas dos mesmos pais) pode se referir a uma delas como upanadi hurasha (esposa velha) e a outra como upanadi zati (nova).

${ }^{311}$ A diferença entre uvibuva e outros deni e madi. Veja capítulo 2.
} 
poderia vir a reforçar uma possibilidade de identidade entre as gerações consanguíneas alternadas, porém, como afirmamos acima, entre os Deni, a nominação retira do parentesco, porque, no limite, não é uma relação entre termos distintos entre si. A feição cíclica se expressa de forma clara entre os colaterais, havendo uma distinção sociológica que não é terminologicamente marcada.

Entre os Deni, não é incomum que avós transmitam seus nomes, porém não podemos dizer que seja uma norma, ou mesmo que seja preferencial e que isto reforçe a identidade entre gerações alternas, como é afirmado para os Kulina (Lorrain 1994). Um dos poucos casos em que um grupo de siblings possui o nome de todos os avôs (do sexo masculino) os três primeiros filhos receberam, pela ordem de nascimento, os nomes de $\mathrm{MF}, \mathrm{MB}$ e FF, isto é, embora o primeiro nomeador tenha sido MF, ele foi seguido por um MB e somente depois FF. Todos os outros "netos" desses homens, quando nomeados por transmissão, receberam nomes que tiveram outras origens. Como já dissemos, o nomeador pode dar sua filha em casamento para o nomeado, logo obter nome da categoria que inclui MB não difere do padrão normal.

Viveiros de Castro já apontou, duas décadas atrás, como a "diferenciação terminológica e/ou normativa entre parentes 'próximos' ou 'verdadeiros' e parentes 'distantes' ou 'classificatórios' [é] de valor estratégico nos sistemas amazônicos” (1993: 165). Na terminologia de parentesco Deni não há uma separação categorial entre consanguíneos lineares e colaterais, mas é possível observar uma relação entre a definição genealógica da aplicação das classes e a proximidade em relação aos parentes lineares. $\mathrm{O}$ afastamento altera a forma de aplicação, consanguíneos colaterais distantes não são de G+1 e G-1 em função da quantidade de laços de filiação entre eles, mas da idade relativa, ou seja, a feição cíclica torna-se preponderante, figurando a idade como parâmetro relevante na aplicação dos termos.

A separação de categorias de lineares e colaterais ocorre, por exemplo, entre os Waimiri-Atroari (Silva 2009). Alguns autores apontam que isto seria encontrado entre os Kulina, que realizam, entre outras, distinções terminológicas entre F e FB, M e MZ (Viveiros de Castro 1978, Lorrain 1994, Florido 2008). Após realizarmos a pesquisa de campo entre os Deni, percebemos que Adams tinha razão ao entender que, para os Kulina, o que outros autores apontavam como sufixo indicador de distância era, na verdade, um termo de parentesco referencial. Os vocábulos apresentados por diferentes autores para FB podem ser traduzido como a indicação que se trata de um "irmão do 
pai" e não de um "pai distante"; que a diferença entre os termos abi (F) e abi ohuaha (FB) é que o termo ohuaha corresponde a um termo de parentesco que indica "irmão dele", tal como o "uvaa" entre os Deni. Isto aparece em todas as categorias colaterais que os diferentes autores fornecem, mas são fórmulas descritivas dos parentes colaterais e não categorias de parentesco. Seria possível traduzir os kin types em todas as línguas humanas, mas isto não significa que eles existam como categorias de parentesco em todas elas.

Um levantamento das posições genealógicas a que se aplicaria determinado termo consanguíneo não contribui para o entendimento das categorias. Se um dos limites de aplicação se encontra na determinação genealógica, posições genealogicamente distantes poderiam, sem fugir ao que seria a norma, estar em qualquer uma das gerações centrais. Diferente do que ocorre no domínio dos afins, em que aqueles envolvidos nas relações assimétricas podem trocar de posições e inverter a relação entre idade e geração, no domínio consanguíneo isto não ocorre, pois a idade relativa é o princípio fundamental, que só não atua quando há proximidade genealógica ${ }^{312}$. A própria diferença entre as classes só é compreensível ao considerarmos os usos vocativos dos termos de parentesco.

Temos, por um lado, a terminologia de referência, um modelo a partir do qual as relações se organizam, e, por outro, a terminologia vocativa que é a forma como as pessoas envolvidas nestas relações se tratam. Vimos que há pares de relações em oposição, sem existir uma graduação entre elas, ou seja, as categorias diferem qualitativamente e não quantitativamente. Esse quadro serve como base para as normas que regem o comportamento entre os parentes e ele funciona como um referencial último para as relações empíricas. A terminologia vocativa Deni estabelece diferenças de grau entre as classes, o que decorre das práticas e das distâncias, portanto, devemos atentar para algumas normas antes de considera-la apropriadamente.

\section{Normas relacionais e atitudes}

As normas que regem os comportamentos entre parentes têm como base as relações informadas pela terminologia, mas, como já apontou Lévi-Strauss (1996

\footnotetext{
${ }^{312}$ Pelo que sabemos os únicos casos em que, por exemplo, uma pessoa mais velha se refere a uma mais jovem como "mãe" são aqueles em que esta última é MZ, isto é, é um consanguíneo genealogicamente próximo.
} 
[1945]) e os Deni são mais um exemplo disto, a relação não é de determinação. Há alguns padrões mais fortemente empregados, como, por exemplo, o serviço da noiva, que não está restrito a este contexto etnográfico, ocorrendo amplamente nas terras baixas da América do Sul (Shapiro 1984). Outras, como as relações jocosas ou sexuais, nem sempre ocorrem entre aqueles cujos vínculos permitiriam estes comportamentos. As categorias não determinam apenas um comportamento, havendo variações significativas entre como são realizadas empiricamente as relações.

O padrão atitudinal Deni, para os parentes de $\mathrm{G} 0^{313}$, é semelhante aquele apresentando por Rivière (2001 [1984]) para os Yecuana. Como chama a atenção Silva, este padrão rejeita "uma equação direta entre a consanguinidade e as categorias de proximidade social" (2004: 670), ou seja, ser parente (uvibuva) não significa que as relações são socialmente próximas e livres. Tomando a escala ${ }^{314}$ que vai da maior $(++)$ ou menor (+) intimidade social até a menor (-) ou maior (- -) distância social temos:

Tabela 1 - Sistema atitudinal para G0

\begin{tabular}{|c|c|c|c|c|}
\hline $\begin{array}{c}\text { Parente }^{315} \\
\text { Ego }\end{array}$ & $\begin{array}{c}\text { Irmãos } \\
\text { Consanguíneo }\end{array}$ & $\begin{array}{c}\text { Irmãs } \\
\text { Consanguíneo }\end{array}$ & $\begin{array}{c}\text { Primo cruzado } \\
\text { Afim }\end{array}$ & $\begin{array}{c}\text { Prima cruzada } \\
\text { Afim }\end{array}$ \\
\hline$\hat{0}$ & - & - - & ++ & + \\
\hline q & - - & - & + & ++ \\
\hline
\end{tabular}

Neste patamar, há uma maior proximidade com os afins do que com os consanguíneos. Irmãos tendem a ter relações marcadas por respeito e evitação, sendo maior entre os de sexo oposto do que entre os de mesmo sexo. Entre eles não há jocosidade, existindo um clima de respeito, as brincadeiras são imadipei. Irmão e irmã quase nunca ficam sozinhos em um local, há entre eles pouca cooperação em atividades e trocas de presentes. Quando um homem casado retorna de uma caçada/pescaria, sua irmã pode ir até sua casa para receber um pedaço de carne/peixe, porém a entrega é feita

\footnotetext{
${ }^{313}$ Esta é uma forma adotada para facilitar a descrição, o G0 aqui corresponde ao esquema terminológico apresentado anteriormente, tal como serão G+1 e G-1 apresentados posteriormente.

${ }^{314}$ Como aponta Silva (2004), esta forma de representação adotada por Rivière introduz uma gradação no esquema binário empregado por Lévi-Strauss para mostrar a relação entre terminologia e atitude.

${ }^{315}$ Correspondem as categorias Deni, mas adotamos os termos do português para facilitar a apresentação. Embora a terminologia apresente termos para irmã(o/s) levando em conta a idade relativa, a relação é uma.
} 
pela cunhada $(\mathrm{BW})$. As distribuições dos resultados das caçadas/pescarias têm amplo escopo, não se restringindo aos consanguíneos próximos do caçador. Uma senhora, casada com um professor, disse que era alvo de muitas fofocas porque dava muitos presentes para o seu irmão, como carretéis de linha de nylon, anzóis, etc., além de suas casas serem localizadas lado a lado, longe de todos os outros irmãos.

Irmãos de mesmo sexo podem cooperar em atividades, mas, comumente, não são beneficiários diretos do trabalho, isto é, podem trabalhar com um cunhado (ZH) na construção da casa do pai, mas muito raramente um trabalha para o outro. Um dos professores, que não possuía genros, teve que pedir para seus cunhados e irmãos para construírem sua casa durante sua ausência para participar do curso de formação de professores. Os irmãos receberam um pagamento maior e estipulado anteriormente pelo serviço, os cunhados não. Neste nível reina, entre os consanguíneos, um clima de respeito e as brincadeiras entre eles são imadipei, khema $^{316}$.

A proximidade social ocorre entre os afins que tem relações mais livres, marcadas pela jocosidade e maior contato físico. A maior liberdade ocorre entre afins de mesmo sexo, pois, entre os de sexo oposto pode ser mantido certo distanciamento para que sejam excluídas as relações sexuais. A lógica é que nem todos os afins de sexo oposto que brincam entre si são parceiros sexuais, mas aqueles que não brincam não são. A proximidade corporal parece ser um dos parâmetros mais relevantes, pois os vínculos estabelecidos pela nomeação também marcam a proximidade, porém não implicam contato físico livre.

Afins de mesmo sexo se abraçam constantemente, deitam em uma mesma rede, etc.; os de sexo oposto são os que competem durante as festas e rituais, lutando, perseguindo um ao outro, ou engajando-se em outras formas de antagonismo que envolvem contato corporal. Entre as atividades que envolvem afins de sexo oposto estão corridas para se apossar de alimentos que uma das pessoas segura, ou perseguições quando um dos sexos se tornam animais, ou lutas para desenterrar alimentos enterrados, ou espécies de cabo de guerra, etc.. Os de mesmo sexo pode se engajar em brincadeiras de cunho sexual, combates simulados, etc..

Este quadro em G0 é invertido nas gerações adjacentes, nas quais afinidade e consanguinidade passam a corresponder, respectivamente, ao afastamento e a

\footnotetext{
${ }^{316}$ Que traduzem por pecado. Não saberíamos dizer qual seria o sentido original do termo, se é que existia. Geralmente ele é pronunciado em conjunto com imadipei. Ver acima.
} 
proximidade social. Não se trata de uma inversão simétrica, pois os polos não são trocados, isto é, afins de mesmos sexo não se tornam os mais afastados e nem consanguíneos de sexo oposto os pais próximos. De uma forma geral, as relações entre pessoas de sexo oposto continuam sendo menos próximas (ou mais distantes) do que as que ocorrem entre o mesmo sexo.

A relação genro-sogra (uhirubadi - ukhashu) e nora-sogro (uhirumadini - kuku), isto é, entre afins de diferente geração e sexo, são as mais socialmente distantes possíveis, marcadas por forte evitação e respeito: não se olham diretamente, não conversam entre si e evitam fazer atividades sozinhos. Entre genro-sogro (uhirubadi$k u k u$ ) e nora-sogra (uhirumadini - ukhashu) há respeito, não são feitas brincadeiras, mesmo que possam participar de atividades em conjunto, sem a necessária presença de outras pessoas, isto só ocorre, na maioria das vezes, se são afins efetivos. O contato físico deve ser evitado e as relações sexuais são interditas, sendo, invariavelmente, listadas quando se verbaliza sobre a canibalização post mortem por Hamu.

As relações entre pais e filhos são mais próximas, embora não sejam marcadas pela jocosidade, não há a necessidade de respeito. No caso de pais e filhos genealogicamente próximos as relações são mais livres, tornando-se menos próximas a medida que se tornam pessoas social-genealogicamente afastadas. As pessoas podem falar livremente, porém, entre as de sexo oposto, haverá certa reserva, evitando ficarem sozinhos se não forem parentes próximos. As relações são livres e próximas, porém elas não mantêm tanta interação como ocorre entre os cunhados de mesmo sexo.

Afinidade e consanguinidade constituem macro classes que organizam os comportamentos $^{317}$, a alternância entre mesmo nível e o outro é acompanhada pela mudança entre proximidade e distância. Independente do ciclo, as relações entre pessoas de mesmo sexo e sexo oposto mantem-se inalterada, a identidade sexual indica menor afastamento (ou maior proximidade) e a diferença corresponde a um maior afastamento (ou menor proximidade). Isto fica visível se considerarmos como são organizadas as relações nas gerações centrais, como nos gráficos a seguir.

\footnotetext{
317 Como mostram Rivière (2001 [1984]) e Silva (2004) este tipo de arranjo é apenas um dos casos possíveis da combinação. É o que se encontra entre os Deni, não sendo encontrados necessariamente em toda parte.
} 
Tabela 2 - Sistema atitudinal para as três gerações medianas

\begin{tabular}{|c|c|c|c|c|}
\cline { 2 - 5 } \multicolumn{1}{c|}{$\mathrm{G}+1$} & Pai & Mãe $^{318}$ & Sogro & Sogra \\
\hline$\hat{0}$ & ++ & + & - & -- \\
\hline$\phi$ & + & ++ & -- & - \\
\hline
\end{tabular}

\begin{tabular}{|c|c|c|c|c|}
\cline { 2 - 5 } \multicolumn{1}{c|}{ G 0} & Irmãos & Irmãs & Primo cruzado & Prima cruzada \\
\hline $0^{\lambda}$ & - & -- & ++ & + \\
\hline+ & -- & - & + & ++ \\
\hline
\end{tabular}

\begin{tabular}{|c|c|c|c|c|}
\cline { 2 - 5 } \multicolumn{1}{c|}{ G -1} & Filho & Filha & Genro & Nora \\
\hline$\delta$ & ++ & + & - & -- \\
\hline$\phi$ & + & ++ & -- & - \\
\hline
\end{tabular}

Esta representação, embora permita que percebamos a alternância nos padrões entre consanguíneos e afins, equaciona a representação de relações desiguais. Podemos estabelecer um continuиm entre proximidade e afastamento social, no qual poderiam ser dispostas todas as relações de parentesco. Os dois polos seriam formados pelas relações entre os afins, estando os consanguíneos distribuídos próximos ao centro, como vemos no gráfico para Ego Masculino.

Figura 10 - Gradiente de proximidade e distância

\begin{tabular}{|lr|}
\hline sogra $>$ sogro $>$ irmã $>$ irmão $>$ mãe $>$ pai $>$ avô(ó) $/$ neto(a) ${ }^{319}>$ cunhada $>$ cunhado \\
\hline distância/evitação & proximidade/jocosidade
\end{tabular}

Entre as gerações adjacentes se coloca a questão da autoridade, não é apenas proximidade/distância social, o poder político também é um traço relevante. Os sogros (de ambos os sexos) têm, geralmente, poder sobre seus genros (do sexo masculino),

\footnotetext{
${ }^{318}$ Há uma característica interessante, pois, para os parentes genealogicamente próximos, isto é, aqueles que são pai (F) e mãe (M) no uso brasileiro desses termos, as relações são mais próximas e livres com a mãe. Possivelmente, isto decorre dos filhos terem maior afeição e proximidade com a mãe do que com o pai, sendo o desejo de voltar a morar com os próprios parentes (isto é, abandonar a residência uxorilocal) formulado, quase que invariavelmente, enquanto a vontade de morar com a mãe.

319 É difícil caracterizar a relação entre estas categorias, pois todos os velhos são referidos como avós, mesmo aqueles que originalmente seriam classificados como afins, o que resulta em comportamentos do tipo "cunhado(a)" com pessoas que são referidas por estes termos. O comportamento dos avós com os netos é geralmente apontado como de proximidade e jocosidade, porém mais limitada do que com os cunhados, é difícil, contudo, separar o comportamento dos avós daquele que os adultos têm com as crianças que ainda não dominam as categorias de parentesco.
} 
podendo se valer do trabalho deles, algo que não destoa da paisagem amazônica. Os pais não têm autoridade sobre os filhos casados do sexo masculino, possuindo influência direta sobre eles, unicamente, quando são chefes (patarahu e paturuva), condição que possibilita a atração dos filhos recém-casados para sua proximidade e a mobilização do seu trabalho. Os Deni tenderiam a concordar com Dreyfus (1993), de que a chefia é um polo atrator, que influencia a composição das parentelas e dos laços de parentesco.

O comum é que um pai proveja para o filho, com pouca colaboração deste, até que ele deixe sua casa para se casar, quando, então, passa a produzir regularmente para o sogro e, indiretamente, também, para a casa materna. A produção de um homem anterior ao casamento existe apenas esporadicamente, exceto nos casos em que este já pediu uma mulher em casamento e presta o serviço da noiva antes de efetivar a união, dividindo sua produção entre sua casa e a dos seus sogros. Até que se efetive o casamento, o trabalho de um homem será esporádico, mas após a união será constante, sob o risco de perder a esposa, caso seja julgado preguiçoso (ibude). Um homem deve prestar serviços para o sogro, mas o mesmo pode ser dito em relação ao cunhado (WB) que se beneficia do trabalho do marido da sua irmã (ZH).

Há certa semelhança entre o contexto Deni e o Kulina no que tange ao trabalho masculino. Entre estes últimos, segundo Pollock (1985a), os homens, quando deixam de ser criança, são afastados da residência materna, passando a se alimentar livremente em todas as casas da aldeia, sem a necessidade de uma contrapartida produtiva. Entre os Deni, embora o vínculo nutricional com a casa materna não seja cortado com a adolescência, não se espera que os adultos jovens produzam regularmente, embora possam ser criticados caso nunca o façam, jamais são obrigados a sair da casa dos pais. Antes de casarem, os jovens se alimentam em diferentes residências além de sua própria. Em ambos os casos, apenas homens casados trabalham, primeiro para seus sogros e cunhados, posteriormente para seus filhos.

Filhas e noras mantêm uma relação diferente, pois a regra de residência uxorilocal faz com que mães e filhas habitem na mesma residência desde o nascimento até a vida adulta destas últimas. Nora e sogra, geralmente, não trabalham em conjunto, exceto em ocasiões extraordinárias, como na preparação de refeições coletivas para rituais ou mutirões, etc.. De uma maneira geral, as mulheres trabalham mais para si do que os homens, pois, desde novas, realizam as tarefas femininas para si próprias e para outros 
moradores da casa, recebendo uma menor quantidade de trabalho da mãe e fornecendo menos para a sogra.

\section{A terminologia vocativa}

Até o momento, apresentamos as oposições binárias que estão na base da estrutura do parentesco Deni: consanguinidade e afinidade, mesma e outra geração, identidade e diferença sexual, mais ou menos idade. São nesses termos que se pensa sobre a questão, mas eles não são, necessariamente, operacionalizados cotidianamente. Algumas categorias referenciais possuem um correspondente vocativo imediato, já outras são subdivididas em sua aplicação cotidiana em certo número de variantes, e outras, ainda, são aglutinadas em macro classes.

É interessante notar que, apesar da língua deni não correr nenhum risco de extinção, parte dos termos vocativos foi incorporada do português. Esta é uma característica muito interessante, pois pouca foram as substituições, isto é, situações em que algum termo da língua deixou de ser utilizado para dar lugar a vocábulos em português. A utilização da língua dos kariva permitiu a expressão de gradações que existiam ao nível da prática, mas não eram marcadas linguisticamente.

A incorporação dos termos do português permite que ocorra uma distinção terminológica que leva em conta uma oposição concêntrica (Silva 1995), expressando a oposição sociológica "próximo e distante" que tem valor estratégico nos sistemas amazônicos (Viveiros de Castro 1993). Embora haja termos nativos para os cônjuges, não havia entre os Deni "modificadores linguísticos que distinguem consanguíneos e afins 'próximo-reais' daqueles 'distante-classificatórios"” (Viveiros de Castro 1993: 167), que desempenham um papel fundamental em outros contextos. Há formas na língua deni para distinguir os parentes próximos dos distantes, como quando apontam que algumas pessoas genealogicamente próximas são uvibuva.aride ("parentes de verdade/reais"), para indicar que sua relação com elas é mais próxima do que com outros moradores da aldeia.

Dispondo os termos vocativos na grade dravidiana teríamos: 
Figura 11 - Terminologia vocativa Deni para Ego masculino

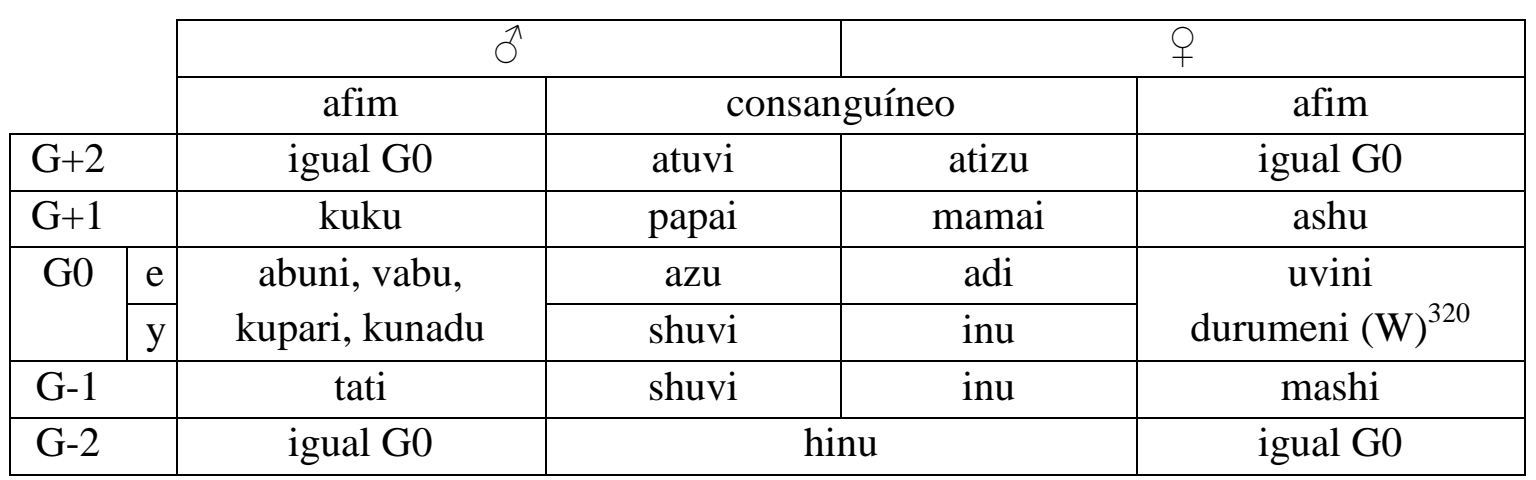

Nossos dados sobre os termos vocativos possuem um forte bias masculino, pois pudemos observar mais frequentemente interações dos homens entre si do que destes com as mulheres e destas entre si. Estes são os termos comumente empregados, havendo outros, com menor aplicação, que não foram incluídos no gráfico. Por exemplo, observamos pessoas que genealogicamente seriam "irmãos" (primos paralelos), e se concebem enquanto tais no uso de termos de referência, chamarem-se de "seu primo 321 " de forma recíproca; afins simétricos se chamarem mutuamente de "prefeito", entre outros casos raros e restritos.

Os termos papai e mamai, oriundos diretamente do português, são utilizados para consanguíneos ascendentes tanto lineares quanto colaterais. A incorporação destes termos do português é interessante, pois eles substituíram completamente os termos que existiam anteriormente ${ }^{322}$. O equacionamento da paternidade/maternidade com as relações do branco, poderia ter como razão forçar nos kariva o reconhecimento da humanidade dos Deni. As relações de parentesco que os brancos tentavam forjar com os indígenas, chamando-os de filhos, eram mostradas para estes como existindo entre os próprios madiha e seus parentes.

Ainda no domínio consanguíneo, podemos ver como a idade é relevante na operacionalização do parentesco, pois os mais novos (irmãos e filhos ou irmãs e filhas) são aglutinados em categorias que só mantêm a divisão sexual. À exceção dos termos para avós e netos, que são aplicáveis, ou a posições genealógicas restritas, ou a todas as

\footnotetext{
${ }^{320}$ Há muitos termos possíveis para a esposa, ao ponto de não podermos dizer que conhecemos todos: durumeni, kuze, meni, muze...

${ }^{321}$ Um dos homens envolvidos nesta relação chamava várias pessoas de "seu primo", sendo por elas assim chamado. Este senhor, de certa forma, assumia um comportamento de afim com todas as pessoas, talvez isto tenha colaborado para descolar suas relações consanguíneas do padrão normal, realizando uma incorporação sui generis de termos do português.

${ }^{322}$ Sabemos que anteriormente o pai seria chamado de vava, não sabemos qual seria o termo para mãe.
} 
pessoas muito velhas ou muito novas, há uma grande divisão entre os consanguíneos mais velhos, que são de dois tipos distintos, e os mais novos, que são uma massa amorfa sem divisão geracional. A igualdade entre os termos de dois pares de recíprocos faz com que se estabeleçam grandes variações nas formas com que grupos de siblings tratam parentes consanguíneos distantes.

Por exemplo, se meu irmão mais velho $(a z u)$ chama um homem mais velho do que eu de shuvi, eu posso vir a chamar este homem azu (irmão mais velho) ou papai, ou seja, posso entender que ele é irmão do meu irmão ou filho do meu irmão, sendo convertido, neste último caso, em meu pai pela diferença de idade. Esta forma de variação é perceptível quando se tratam de crianças pequenas, filhas de mães solteiras (ou divorciadas). As crianças iniciam a utilização dos termos vocativos aplicando aos tios (MZ e MB) mais novos que a mãe os termos para irmãos mais velhos (azu e adi). Se, após contrair (novo) matrimônio, a mãe deixar a criança sob os cuidados dos seus pais (avós da criança) e passar a morar com o (novo) marido, ela provavelmente manterá este padrão de emprego dos termos de parentesco, acabando por transformar seus tios em irmãos e seus avós em seus pais. Esta mudança no emprego dos termos e de classificação vai repercutir futuramente na política matrimonial que envolverá seus pais/avós que irão procurar parceiros matrimoniais para seus netos/filhos.

A afinidade apresenta um quadro diferenciado, pois é nela que a incorporação de termos externos vai possibilitar a expressão de uma gradação pormenorizada entre aqueles que são afins simétricos. Como indicamos no capítulo 2, os Deni afirmam que, antigamente, aplicavam o termo ukheve para os afins simétricos, vocabulário que foi substituído por abuni e, possivelmente, ukheve era o termo que indicava inimizade, tendo sido substituído por abuni quando abandonaram as disposições guerreiras. Atualmente, a forma vocativa abuni $^{323}$ é, geralmente, empregada para os kariva e outras populações não-Deni, ou seja, ela é indicativa de afinidade sócio-política ${ }^{324}$ mais do que afins.

Kupari e kunadu são corruptelas de compadre e cunhado em português e parecem ser utilizadas para diferentes relações de afinidade simétrica. Kunadu é utilizado para afins próximos, não apenas os efetivos, isto é, aqueles propriamente cunhados na

\footnotetext{
${ }^{323}$ A forma vocativa seria vabu ou vabuni, mas ela nunca é aplicada. Durante nossa pesquisa de campo uma pessoa passou a nos chamar assim próximo ao momento em que outros chamava-nos de kupari.

${ }^{324}$ A afinidade sem afins, isto é, virtual ou potencial (Viveiros de Castro 2002).
} 
maneira brasileira de utilização deste termo, mas para afins simétricos socialgenealogicamente próximos. Não são, apenas, primos cruzados, irmãos de cônjuges, ou cônjuges dos irmãos que recebem o termo, porém não há um limite preciso estabelecido. De nossa observação direta, vimos sua utilização entre MMZH-WZDS, mas não entre WFBS-FBDH, parecendo que a utilização depende de outros fatores que não apenas as cadeias de casamento e filiação.

Kupari é o termo usado para os afins que não são genealogicamente próximos, mas pode ser usado entre aqueles que são socialmente próximos. São afins distantes, mas que ainda são passíveis de serem contados entre os uvibuva, isto é, são parentes com quem se mantêm vínculos de afinidade. A utilização do termo indica proximidade, que, pode mesmo, ser maior ou menor do a existente entre aqueles que se tratam por kunadu, mas é, necessariamente, maior do a que se estabelece com os abuni. Entre os kunadu pode se formar um comportamento de respeito, em que se estabelece com o mais velho (geralmente quando WB é mais velho) uma relação semelhante a que se tem com o sogro, marcada por respeito, mas isto nunca acontece entre aqueles que se tratam por kupari, que, invariavelmente, possuem atitudes descontraídas um com o outro.

Os outros termos vocativos são aqueles utilizados entre afins de gerações adjacentes, sendo utilizados conforme as uniões matrimoniais realizadas ou o desejo de realizar uniões futuras. Uma pessoa que queira casar seus filhos com determinadas pessoas irá mantê-las como afins de G-1, utilizando para elas os termos apropriados, mas, se não tiver este interesse, pode vir a chamar estas mesmas pessoas como afins de $\mathrm{G}+1$, sinalizando seu desejo de se casar (ou ter relações sexuais) com seus filhos. $\mathrm{O}$ uso vocativo estabelece o corte no ciclo dos afins, fixando quais são os sogros e quais os genros.

Um caso ilustra bem esta questão. Um jovem casou com uma mulher bem mais velha do que ele e que já tinha muitos filhos e filhas. O rapaz continuou a tratar WD, mais velha do que ele e com filhas pequenas, como ashu (WM) e não como mashi (SW) ou inu (D), isto é, manteve a filha de sua esposa como uma sogra (e não como nora ou filha), o que sinalizava seu desejo de casar-se com uma das filhas dela. Isto acabou por se efetivar, sendo realizada a união com WDD, ou seja, mesmo que tenha casado com uma mulher, ele manteve os usos vocativos que permitiriam que ele desposasse uma moça descendente de sua primeira esposa. 
A incorporação de termos de relação do português possibilitou que as distinções sociológicas concêntricas, características do dravidiano amazônico, tenham expressão terminológica entre os Deni. As oposições escalares, contudo, parecem ter uma marcação semântica apenas na afinidade, ou melhor, até onde sabemos, para os homens, apenas entre os afins de mesmo sexo são expressos diferentes proximidades e distâncias sócio-políticas ao nível terminológico. O problema estaria em dizer que, ainda, se tratam de relações de parentesco e não apenas de vínculos marcados pelo uso de certos vocábulos, como seriam as outras relações nomeadas.

\section{4 - Outras relações}

Consideramos aqui algumas relações que possuem termos específicos e que são geralmente concebidas como ocorrendo entre pessoas que mantinham entre si determinadas relações de parentesco. Os vínculos anteriores são comumente expressos com termos da terminologia referencial de parentesco, sendo, algumas vezes, apontada que a mudança é na forma de tratamento entre os envolvidos, que se faz acompanhar de alterações no comportamento tanto a nível normativo quanto prático. Elas parecem se situar ao nível do parentesco ou além, já que este aparece como pressuposto ou reforçado, não se tratam de coisas como "parentesco ritual", fictício, ou etc.. Muitas delas ocorrem entre pessoas que são efetiva ou potencialmente cônjuges e/ou cunhados/as entre si.

\section{Banaha}

Até onde sabemos, a única relação nomeada ${ }^{325}$ que envolve inicialmente um homem e uma mulher está vinculada diretamente com a realização de um casamento futuro entre eles. Ela surge quando uma mulher é criada, desde a infância (ou mesmo antes do nascimento), pelo futuro marido, isto é, quando o serviço da noiva se inicia muitos anos antes que o casamento se efetive, passando a futura esposa a ser chamada de banaha ${ }^{326}$. O casamento é sempre visto como envolvendo o fluxo de bens e trabalho

\footnotetext{
325 Como já apontamos no acima, além de termos específicos para os cônjuges, a relação de casamento propriamente dita é nomeada. Trata-se de uma terminologia que destaca a relação odorífica que se estabelece entre os cônjuges.

${ }^{326}$ De forma espontânea ouvíamos geralmente pukha banaha, isto é, a banaha dele. Não sabemos se o termo é usado no vocativo, mas pode ser possuído na primeira pessoa de forma referencial - aparecendo a forma ukha banaha "minha banaha" em conversas com o antropólogo.
} 
para os sogros, mas os casos que envolvem mulheres recém-nascidas, ou mesmo ainda não nascidas, a relação é muitas vezes expressa em termos de um vínculo entre o homem e a futura esposa e não entre ele e os sogros. Os parentes da moça não recebem termos diferentes daqueles empregados para os parentes de uma esposa comum, nem há vocábulos específicos para os que assim se unem.

Os casamentos estabelecidos desta forma, em que um dos cônjuges toma para si uma parte do trabalho parental, dificilmente são desfeitos. Há o reconhecimento geral de que a mulher sempre será esposa do homem que a criou, sendo muito reprovado quando não se concretiza uma união duradora. Nesses matrimônios os pais parecem não possuir autoridade sobre a filha que, muitas vezes, se muda para a casa dos parentes do marido, ou uma casa nova, com a efetivação do casamento. A banaha parece ser uma espécie de filha para seu marido, mantendo sua posição de afim efetivo, embora tenha seu corpo construído como parente consanguíneo (Viveiros de Castro 2002) de seu marido.

O processo de consanguinização da esposa, desde a mais tenra idade, é tematizada na narrativa sobre o surgimento das cobras que mencionamos no capítulo 2 . A esposa do Anta é sua banaha, pois é criada por ele desde criança. Este processo fabrica o parentesco com o marido mais do que com seus pais e irmãs, o que resulta na vingança da esposa do Anta contra seus próprios irmãos. Este enunciado mostra que uma banaha vê os seus próprios consanguíneos como se fossem afins, que se tornam alvo da sua violência destrutiva de vingança.

Este é o matrimônio ideal, pois se baseia em um vínculo instaurado quase sempre quando os cônjuges são ainda muito jovens e perdura após a morte, tanto nas aldeias celestes quanto na viuvez. A relação com uma banaha é durável, até em casos de viuvez, dizem que o que sobrevive deve esperar muitos anos até contrair um novo matrimônio, isto é, deve manter um luto prolongado. Este parece ser o par ideal para a reunião após a morte, pois o vinculo é mantido para o cônjuge que permanece vivo, sendo uma relação que não é afetada pela morte, logo, poderia ser a base para uma continuidade das relações de afinidade no post mortem, isto é, um casamento marcado por um processo de aparentamento equivalente a filiação, ou seja, um casamento cujo conteúdo afim entre os envolvidos é mínimo. 


\section{Ikatuviaride e itavari.}

Estas são duas relações que se estabelecem entre pessoas de mesmo sexo que se tratavam reciprocamente pelos termos para primo(a) cruzado(a)/cunhado(a)/filho(a) de sogros, isto é, ocorrem entre afins simétricos. A existência de determinados vínculos prévios é condição para seu estabelecimento, sendo espécies de aprofundamentos das relações que devem ocorrer normalmente entre eles. Há claras diferenças entre as duas, mas elas parecem ser muito semelhantes ao nível das normas e comportamentos.

Ikatuviaride é uma relação local e espontânea, surgindo entre afins simétricos de mesmo sexo, ou seja, ocorre entre mulheres ou entre homens, mas nunca entre uma mulher e um homem. Ela envolve pessoas que se visitam frequentemente, brincam muito entre si e colaboram em atividades, ou seja, mantêm comportamentos que se ajustam perfeitamente a norma e, por isto, reconhecem e são reconhecidos pelos outros como possuindo este tipo de relacionamento. É um termo utilizado para sinalizar que duas pessoas são muito próximas, fazendo muitas atividades junto, seja caçar, trabalhar no roçado, ou ter relações sexuais com a mesma pessoa, isto é, eles participam de sexo sequencial (Crocker \& Crocker 2004) com a mesma pessoa. Isto é válido tanto para duas amigas que encontram um homem pelo caminho, quanto o inverso, embora os poucos relatos existentes apontem, em tom jocoso, a incapacidade dos homens de satisfazerem as duas mulheres.

Não parece que o sexo sequencial seja uma expressão ritual como seria entre os Canela, mas pouco se fala da sua ocorrência, ou melhor, pouco se fala para os kariva. Provavelmente, a condenação desses comportamentos expressa pelos brancos, como apontou Crocker \& Crocker (2004) para os Canela, acabou por levar ao seu abandono ou a sua ocorrência à margem do conhecimento dos não-Deni. Pelo que pudemos perceber, embora haja esta proximidade, raramente eles (ikatuviaride) tornam-se afins efetivos, isto é, não há uma tendência (ou preferência) para que eles se casem com os irmãos dos seus companheiros, tornando-se cunhados reais.

Itavari é um termo vocativo que indica uma relação entre pessoas de diferentes localidades. Ela é estabelecida de maneira formal durante a realização de um imaamushinaha banivadanaha, uma grande festa inter-aldeã. Só pudemos descobrir dois moradores da aldeia Cidadezinha (um pai e um filho) que se envolveram neste tipo de vínculo com pessoas do Xeruã, durante um destes rituais, décadas atrás. Sua 
narrativa aponta que o ritual envolveu um grande numero de pessoas, tendo ocorrido antes das epidemias de sarampo que dizimaram boa parte da população Deni. Em dado momento, os homens se dividiram em dois grupos, um que correria com pedaços de caça e outro que correria para pegar esses pedaços. Os homens de diferentes origens foram fazendo desafios um aos outros, formando pares que passaram a se chamar de itavari reciprocamente e de forma vitalícia.

A disputa de corrida por alimentos é chamada de kashinava e ocorre quando há um imaamushinaha, mas, geralmente, opõem homens e mulheres em dois grupos que correm disputando os alimentos. Para o banivadanaha é aberta uma estrada na mata, o kashinava havi (havi - caminho), que termina na aldeia e é usada nestas disputas. A relação de itavari, contudo, só é estabelecida quando há um grande banivadanaha, o que não tem acontecido nas últimas décadas.

Este vínculo envolve os parentes próximos do par, que passam a se considerar itavari e manter proximidade social. Um itavari representa um local de estadia durante visitas à outra comunidade, onde as necessidades do visitante são atendidas por ele. Possivelmente, era uma relação mais comum antigamente, quando cada comunidade se constituía como um grupo_deni isolado, cujos laços podiam se deteriorar para a guerra, época em que os inter-casamentos eram problemáticos. A formalização deste vínculo garantiria que as pessoas de diferentes aldeias estabelecessem relações socialmente próximas, num laço que se estende por toda a vida.

As descrições e narrativas que envolvem os itavari mostram que há grande proximidade entre eles, são como os cunhados socialmente próximos. Eles não podem falar mal um dos outros, não podem se envolver em conflitos, devem sempre dar para seus parceiros, fornecendo alimentação em abundância durante suas estadias na comunidade, etc.. Eles representam afins simétricos ideais, não tanto porque colaboram em atividades conjuntas, mas porque realizam tudo o que se esperaria de um parente de verdade: dão sem pedir em troca, não brigam, não tem raiva um do outro.

Não podemos considerar que tenhamos abordado todas as relações concebidas pelos Deni, mas, possivelmente, estas são as que possuem maior influência nas suas práticas. São elas que circulam livremente, dai terem sido apreendidas no curso da pesquisa de campo. Devemos ter em mente que outros laços existem, mas talvez sejam menos importantes na cosmologia Deni. Estas relações que apresentamos, fruto de 
investigações, entrevistas, e observação de alguns casos concretos, devem ser consideradas agora que passaremos a abordar a rede de parentesco. 


\section{Capítulo 4 - A rede de parentesco}

Analisaremos, agora, a genealogia Deni, uma rede empírica formada por relações de casamento e filiação, tendo por inspiração o uso do método genealógico iniciado por Rivers (1910). Tomar isto como um objeto de análise não é tão trivial quanto parece, pois, como chama a atenção Silva ${ }^{327}$ (2012), há, nos anos recentes, duas facções opostas quanto ao uso desta metodologia: os que apoiam seus usos e aqueles, como Bamford \& Leach (2009) e muitos dos colaboradores de sua coletânea, que se opõem a modelagem genealógica. Isto não é novo no campo do parentesco, pois, como salienta Silva, os estudos do parentesco nascem, no século XIX, com um debate entre Morgan e McLennan e seguem, pelo século XX, com as

"querelas que ficaram conhecidas como 'extensão ou contração das classificações de parentesco' (Malinowski versus Hocart), 'categoria / genealogia' (Maybury-Lewis versus Lounsbury), 'descendência e aliança' (Fortes versus Dumont) e assim por diante, que dividiram a arena de várias maneiras." (2012: 2).

A história dos estudos de parentesco é polarizada desde seu início e, assim, continua ainda hoje.

Tomamos como objeto de investigação a genealogia porque acreditamos em sua validade e, como veremos a seguir, os resultados obtidos a partir de sua análise parecem suportar essa opção metodológica. Não se trata de considerar que ela possui uma existência dada pela (nossa concepção de) biologia e comprovável via DNA, mas, sim, que estamos diante de uma construção social, criada pela memória, e que possui capacidade para influenciar os eventos. Sabemos que o parentesco é um fenômeno diferente do que entende a nossa biologia desde Durkheim (1996 [1912]), mas o que queremos dizer é que a genealogia corresponde aos "registros de uma história infletida, entre outras coisas, [pelas] possibilidades e impossibilidades matrimoniais ${ }^{328}$, e não mais (ou somente) como registro de uma história de relações naturais” (Silva 2012: 29).

Não queremos dizer que cada pessoa que participa da rede a tenha estruturada em sua cabeça, mas, em certos momentos, tornam-se relevantes algumas relações que

\footnotetext{
${ }^{327}$ Silva (2012) apresenta uma discussão sobre os debates realizados sobre o método genealógico nos últimos 150 anos.

${ }^{328}$ Nota nossa. Como afirma Lévi-Strauss (1982 [1949]), estas são definidas pelo parentesco e possibilidades e impossibilidades correspondem, respectivamente, aos vínculos de consanguinidade e afinidade que se estabelecem entre as pessoas.
} 
influenciam as ações no campo matrimonial. A genealogia é o resultado da bricolagem das memórias individuais, cada evento matrimonial, entre os Deni, pode gerar um debate no qual os interessados participam, contribuindo com alguns fragmentos da rede, tornando certos laços importantes, aqueles que são mobilizados nos discursos. O resultado total dessa somatória, feita pelo antropólogo, pode ter, e em nosso caso ela realmente possui abrangência e profundidade maiores do que as que são relevantes para os próprios Deni, isto é, nada garante que o total de vínculos registrados seja relevante para todos os eventos conhecidos. A profundidade temporal resultante desse agregado das memórias pessoais tanto pode deixar de considerar alguns dados relevantes (o que é óbvio para os casamentos mais antigos), quanto manter vínculos irrelevantes (principalmente para os mais recentes).

Iremos realizar alguns testes, visando investigar se o que dissemos, até o momento, sobre os Deni e sua cosmologia está, de alguma forma, infletido na sua rede genealógica. Devemos levar em consideração tudo que dissemos anteriormente sobre a cosmologia, isto é, que há um noção de parentes (uvibuva), uma indistinção dos Outros, que existem entidades supra individuais/corporais que se distribuem por diferentes corpos (compartilham uma perspectiva), que a proibição do incesto é explicitamente formulada, há um cálculo de cruzamento dravidiano, uma tendência cíclica no sistema e a distância é um parâmetro relevante. Vamos relacionar os modelos ideais com as práticas e as memórias sobre elas, ou seja, estamos realizando um exercício no qual o nível empírico do parentesco está em primeiro plano.

O procedimento analítico faz uso de recursos computacionais para investigar as figuras presentes na rede, isto é, procura observar os padrões através de sua decomposição. Utilizamos o MaqPar ${ }^{329}$, o $\mathrm{PUCK}^{330}$, o Pajek ${ }^{331} 3.0$ e a linguagem SQL para realizar a decomposição da rede em elementos que permitem sua apreensão e análise, bem como a leitura de algumas características gerais da mesma. Esta

\footnotetext{
${ }^{329}$ Software criado por Marcio Ferreira da Silva e João Dal Poz Neto e atualmente desenvolvido pelo doutorando Álvaro Junior Pereira Franco, aluno do Programa de Pós-Graduação em Ciências da Computação do IME - USP, no âmbito do Centro de Estudos Ameríndios (CEstA - USP). Para informações sobre a forma de decomposição veja Dal Poz \& Silva (2009).

${ }^{330}$ Hamberger iniciou em 2007 o desenvolvimento do software PUCK (Programme for the Use and Computation of Kinship data), no âmbito do projeto "Traitement informatique des phénomènes de parenté em anthropologie et en histoire: une approche intégrée" (TIPP) dirigido por Michael Houseman e Cyril Grange. Para informações sobre seu funcionamento veja Hamberger \& Houseman \& Grange (2009)

${ }^{331}$ Pajek é um programa para análise e visualização de grandes redes, desenvolvido por Vladmir Batagelj e Andrej Mrvar. Para informações sobre seu funcionamento e forma de utilização veja Nooy \& Mrvar \& Batagelj (2005) e a Pajek Wiki disponível em http://pajek.imfm.si/doku.php (05/07/2013).
} 
metodologia permite, não apenas considerar a rede do ponto de vista de seus indivíduos componentes, que, comumente, corresponde a tomar algumas pessoas como privilegiadas, principalmente quando suas ações servem de exemplo para afirmações que o etnólogo formula a partir de outras considerações, mas também levar em conta características globais.

A abordagem focada na genealogia, isto é, uma análise que parte da consideração do nível prático do parentesco (ou comportamental - Needham 1973) permite um ganho analítico sobre os métodos tradicionais. Veja, por exemplo, o artigo de Houseman \& White (1998), ele mostra que entre os Xavante há mais casamentos entre parentes cruzados próximos do que entre outras populações que apresentam a regra de casamento de primos cruzados, isto é, possuem uma terminologia de parentesco dravidiana. Esta abordagem permite que percebamos as relações que surgem entre o ideal e as práticas.

\section{1 - A construção da genealogia Deni}

Nossa pesquisa foi realizada, em sua maior parte, na aldeia Cidadezinha e, portanto, nossos dados genealógicos apresentam um bias geográfico a partir da memória dos seus moradores. Há mais pessoas relacionadas com estes do que com os moradores de outras localidades, pois, embora tenhamos tido a possibilidade de fazer o levantamento junto à quase totalidade da população do Cuniuá, muitos dos velhos, já aposentados, não estavam nas comunidades quando realizamos uma viagem para todas elas. Pudemos obter muitas informações sobre os residentes atuais do Cuniuá, mas sem grande profundidade temporal/genealógica, e para alguns do Xeruã.

A parte da genealogia que envolve moradores e ancestrais das aldeias do Xeruã é de certa forma precária, sendo, em sua maior parte, baseada na memória de pessoas que, há 20-30 anos, habitavam nesta região, ou correspondem aos conhecimentos construídos pelos próprios Deni do Cuniuá durante breves visitas para realização de festas e/ou partidas de futebol, ou foram transmitidas via radiofonia. Dois irmãos, originários da aldeia Boiador, no Xeruã, contraíram matrimônio na aldeia Cidadezinha em 2012 e isto possibilitou que obtivéssemos algumas informações mais atualizadas sobre seus parentes e os demais moradores da sua comunidade de origem. Em comparação com os dados de Chaves (2001), contudo, vemos que muitos indivíduos 
não foram sequer mencionados durante nosso levantamento, nem os seus vínculos com pessoas já falecidas.

Durante a construção dos dados, foi possível perceber que as pessoas mais velhas dificilmente lembram prontamente dos parentes de seus pais, como se existisse uma lista que pudessem fornecer. Raros eram os casos em que alguém de mais idade sabia indicar quem foram seus próprios avôs, ou mesmo os irmãos de seus pais. A partir de histórias de vida e outras narrativas, foi possível, contudo, obter informações genealógicas a respeito de ancestrais mais remotos de parte da população. A memória genealógica parece ter maior profundidade para os adultos na casa dos 30-50 anos, que, provavelmente, foram aqueles que participaram de outras tentativas de registro de informações genealógicas.

Não fomos os primeiros a realizar esse tipo de investigação na região do Cuniuá. Os Deni listam diversos momentos em que pessoas ligadas ao SIL, ao CIMI, a FUNASA, entre outros, realizaram algum tipo de levantamento censitário (com informações sobre vínculos de parentesco). Como aponta Calavia Sáez (2006), a interação de pesquisadores e indigenistas, preferencialmente com os mais jovens, acaba por resultar em alterações no conhecimento nativo, em alguns aspectos, mais desestruturantes que as ocorridas devido às relações comerciais. Talvez, a memória dos mortos, presente entre os Deni mais jovens, tenha na atuação destes agentes a sua origem, ou seja, o conhecimento/registro feito pelos kariva agiram contra o esquecimento dos mortos (Taylor 1997), com implicações que devem ser exploradas futuramente.

Devemos notar que a diferença está na ligação dos mortos com o presente, já que, muitas das pessoas nomeadas em narrativas de tempos passados (não apenas no tempo dos imabute $^{332}$ ) não estão genealogicamente ligas aquelas vivendo na comunidade Cidadezinha, nem foram mencionadas como ancestrais dos habitantes de outras aldeias, embora possam ser. A maior parte dos atores dessas narrativas não possui um vínculo genealógico com as pessoas do presente, sendo assim, a sua memória não é a do parentesco e, possivelmente, suas ações não atuam sobre os casamentos atuais. A própria rede que conseguimos construir, como veremos, parece alcançar uma

\footnotetext{
${ }^{332}$ Veja capítulo 1 para uma discussão detalhada. Imabute seria o tempo dos antigos, da primeira humanidade, que não possui uma ligação imediata com o tempo presente.
} 
profundidade temporal maior do que a que seria relevante para os eventos matrimoniais mais recentes.

Como uma genealogia é algo que se desenvolve no tempo, foi necessário realizarmos as datações dos eventos da rede: os nascimentos e casamentos. Tomamos como base os dados fornecidos pela FUNASA, sendo realizados alguns ajustes quando necessário, por exemplo, quando a ordem de nascimento não correspondia às afirmações dos próprios Deni. As pessoas nascidas após 2005 tiveram suas datas de nascimento obtidas diretamente em campo, seja pela observação ou informação obtida junto aos pais. Estipulamos, para os casamentos de pessoas ainda vivas, que eles aconteceram um ano antes do nascimento do primeiro filho.

Para datar o nascimento de pessoas já falecidas e seus casamentos foram adotados alguns parâmetros. Nos casos em que só havia um filho com idade conhecida, foi convencionado adotar 20 anos como a idade da mãe quando teve o primeiro filho e 25 a idade do pai, mesmo que, pela nossa observação direta, a maioria das mulheres tenha o primeiro filho com 16 - 17 anos, a taxa de mortalidade infantil ${ }^{333}$ é alta e poderia ser maior antigamente. Nos casos que esses ajustes levavam a desorganização da ordem de nascimento conhecida de alguém já morto, a data de nascimento dos homens foi modificada para respeitar a ordem de nascimento, ou situar as pessoas entre o mais novo e o mais velho do grupo de irmãos. Os casos nos quais as mulheres, em função dos ajustes iniciais, apareciam como tendo filhos fora do que convencionamos ser o seu período fértil, demandaram a realização de ajustes para que a primeira ou a ultima gravidez fosse situada entre os 14 e 45 anos.

Há, entre os Deni vivos ou recém-falecidos, certo numero de gêmeos e existem pessoas falecidas cuja gemelaridade pode ser inferida a partir dos seus nomes. Os gêmeos são referidos como $b a b a$, termo utilizado também na forma vocativa e que pode figurar também como nome pessoal. Baba é a palavra usada para descrever duas bananas que cresceram com seus corpos fundidos, cujo consumo excessivo é responsável pelo nascimento dos gêmeos. Embora não tenhamos muitas informações a respeito, parece que a utilização do termo é restrita ao irmão mais novo, isto é, ao que nasceu depois.

\footnotetext{
${ }^{333} \mathrm{Na}$ aldeia Cidadezinha, em 2011, por exemplo, 10 crianças nasceram e permaneceram vivas por mais de um mês, tendo falecido 3 crianças com menos de 2 anos no mesmo período. Uma taxa de mortalidade infantil de $30 \%$, distante da taxa de 10 por mil que é considerada aceitável pela OMS.
} 
A ordem de nascimento de pessoas falecidas, ou mesmo dos moradores de outras aldeias, não parece ter grande relevância para a memória Deni. Embora seja, comumente, possível descobrir o primeiro e o ultimo filho para a maioria dos conjuntos de siblings, a ordem intermediária é muitas vezes ignorada. Dada a possibilidade de serem gêmeas, as pessoas sem filhos ou sem descendentes de idade conhecida foram consideradas como possuindo a mesma data de nascimento que seus irmãos. Todos os casos em que era possível traçar uma cadeia de filiação até o presente foram datados da forma indicada anteriormente.

\section{2 - A rede Deni}

A rede construída durante a pesquisa é composta por 875 indivíduos, 424 mulheres e 451 homens, e 333 casamentos que envolvem 264 maridos e 276 esposas diferentes. Na sua construção, não consideramos muitas crianças com idades menores de cinco anos, pois, não estando envolvidas em uniões matrimoniais, sua presença não traria nenhum ganho analítico. Incluímos, contudo, ao menos um filho para cada matrimônio fértil de que tínhamos as informações, e que correspondem, em sua maior parte, aos casais que habitam aldeias no Cuniuá.

Segundo a teoria da concepção Deni, uma pessoa é formada pelo acúmulo de sêmen no útero da mãe e, portanto, cada pessoa pode possuir uma única mãe, porém ter muitos pais. Embora a paternidade possa ser partilhada entre mais de um homem e seja possível obter diversos comentários a respeito das pessoas que teriam contribuído para determinado nascimento, não existem muito consenso a este respeito. Comumente, os possíveis pais negam sua participação na geração dos filhos de mulheres casadas com outros homens. Admitir a participação na paternidade implicaria, geralmente, assumir também que era amante da mulher.

Na Cidadezinha, por exemplo, há apenas um caso no qual um homem, sem outros filhos, reivindica a participação na paternidade da primeira filha da esposa de outro, tendo a contribuição para a formação da criança ocorrido antes da mulher ter contraído matrimônio. Nesse aspecto, haveria uma grande diferença em relação aos Kulina, entre os quais, afirma Pollock, a múltipla paternidade é algo muito comum, sendo "quase certo que a maioria, se não todas as crianças da aldeia possuem mais de um 'pai'” (tradução nossa - 2002:53). No caso Deni, os comentários são muitos, mas 
parecem não ter relevância se não for assumida publicamente a participação na gestação de outro homem.

Sempre que uma mulher solteira tem um filho, um pai é atribuído à criança, mesmo que, posteriormente, esta identificação possa ser alterada ou mesmo esquecida. O estabelecimento deste vínculo pode levar, mas não necessariamente, à alteração da relação que os outros filhos deste homem mantêm com esta mulher, ou vice versa. Não importa quantos parceiros a mulher tenha tido antes e durante a gravidez, isto não se torna público. Dizem os Deni que só a mãe sabe realmente quem são os pais de seus filhos, podendo ou não informar aos filhos sobre seus outros pais ${ }^{334}$.

Os Deni diferem dos Kulina que, segundo Pollock (1984), estabelecem um estado de gravidez perpétuo para as mulheres sexualmente ativas. Entre os Deni, após a saída do sangue menstrual, abre-se a possibilidade de que o sêmen seja acumulado, mas, caso a mulher menstrue novamente, ela não é considerada como estando grávida. Em alguns casos é necessária, inclusive, a intervenção xamânica para colocar um espirito (abanu) na barriga mulher e garantir que ocorra a gravidez, o que só pode ocorrer caso não seja o primeiro filho do casal.

Na língua deni, a barriga da mulher é chamada zahani, mas o termo não corresponde apenas ao que todas possuem fisicamente, que é visível e tocável. Quando uma mulher está grávida, ela passa a ser chamada vocativamente por Zahani e o homem responsável por Zeheme, sendo que zehe corresponde à forma masculina para barriga, podendo _me ser o mesmo sufixo abordado no capítulo anterior, relacionado com a causação de algo e a tecnonímia. Com a gravidez, a mulher passa a ser zahani, o continente em que o sêmen do homem foi depositado, parecendo ser um processo em que apenas o homem participa ativamente, não havendo contribuição materna para o desenvolvimento do feto.

Desconfiamos que haja uma diferença entre a primeira gravidez e todas as outras, pois da primeira o marido diz: "upanadi zahani puharu”, sendo upanadi - minha esposa, zahani - a barriga dela e, puharu - expressão utilizada, pelos Deni, para dizer que possuem determinada coisa naquele momento ${ }^{335}$. Para as próximas gestações o

\footnotetext{
${ }^{334}$ Muitas vezes, a mãe informa aos filhos como deveriam se referir a certas pessoas, isto é, quais os termos de parentesco apropriados. Dado que são muitos fatores que podem ser levados em consideração, isto não implica a participação de outros pais na geração da criança.

${ }^{335}$ Por exemplo, se alguém me pergunta se tenho peixe, respondo puharu se tenho peixe ou phiraru se não tenho.
} 
marido vai dizer: "upanadi zahani puha.mita.ru", sendo que o dicionário de Koop \& Koop aponta para o sufixo “_mita (suf. v.) iterativo: de volta para um lugar ou condição anterior; ação repetida ou contínua" (1985: 73). A primeira gravidez indica que a mulher possui o continente, as próximas que ele voltou a ser ativado.

Estas características do parentesco Deni foram levadas em consideração ao ser construída a genealogia. A relação de filiação entre pai e filho corresponde à afirmação da existência de uma relação informada pela formação do corpo do ultimo pelo sêmen do primeiro, já entre a mãe e os filhos seria a deles terem saído da barriga dela. Isto resultou em uma rede que apresenta um total de 1589 relações de filiação, existindo alguns casos em que não se conhece ambos os pais de alguém, resultado de uma lacuna na memória, ou mesmo falta de relevância, a respeito dos progenitores de determinada pessoa e não pela possibilidade de nascimentos que não envolvam ao menos um pai e a mãe.

A análise da rede, a partir de algoritmos ${ }^{336}$ do software Pajek, aponta que ela é composta por 8 gerações, ou seja, podemos traçar uma linha com profundidade máxima de 7 relações de filiação, resultando no limite máximo de 14 relações consanguíneas entre duas pessoas. O Puck 2.0.40 aponta que a profundidade média é de 3,22 gerações para cada um dos indivíduos componentes. Excluídos os casamentos, a rede com que trabalhados é assim representada a partir do cálculo geracional do Pajek:

\footnotetext{
${ }^{336} \mathrm{O}$ algoritmo parte, unicamente, da consideração dos vínculos de filiação, não existindo relações deste tipo em um mesmo nível geracional, mas algumas delas podem possuir um comprimento maior que uma geração. As idades são irrelevantes, podendo pessoas mais velhas estarem situadas em gerações abaixo de pessoas recém-nascidas. O caso Deni apresenta uma linha com profundidade de 8 gerações, mas a existência de uma cadeia de filiações com espaço de uma geração entre elas não é um pressuposto do cálculo do Pajek. Veja http://intersci.ss.uci.edu/wiki/index.php/P-graph_generation_levels (01/04/2013) para uma explicação simplificada de como é feito o cálculo.
} 
Figura 12 - Relações consanguíneas

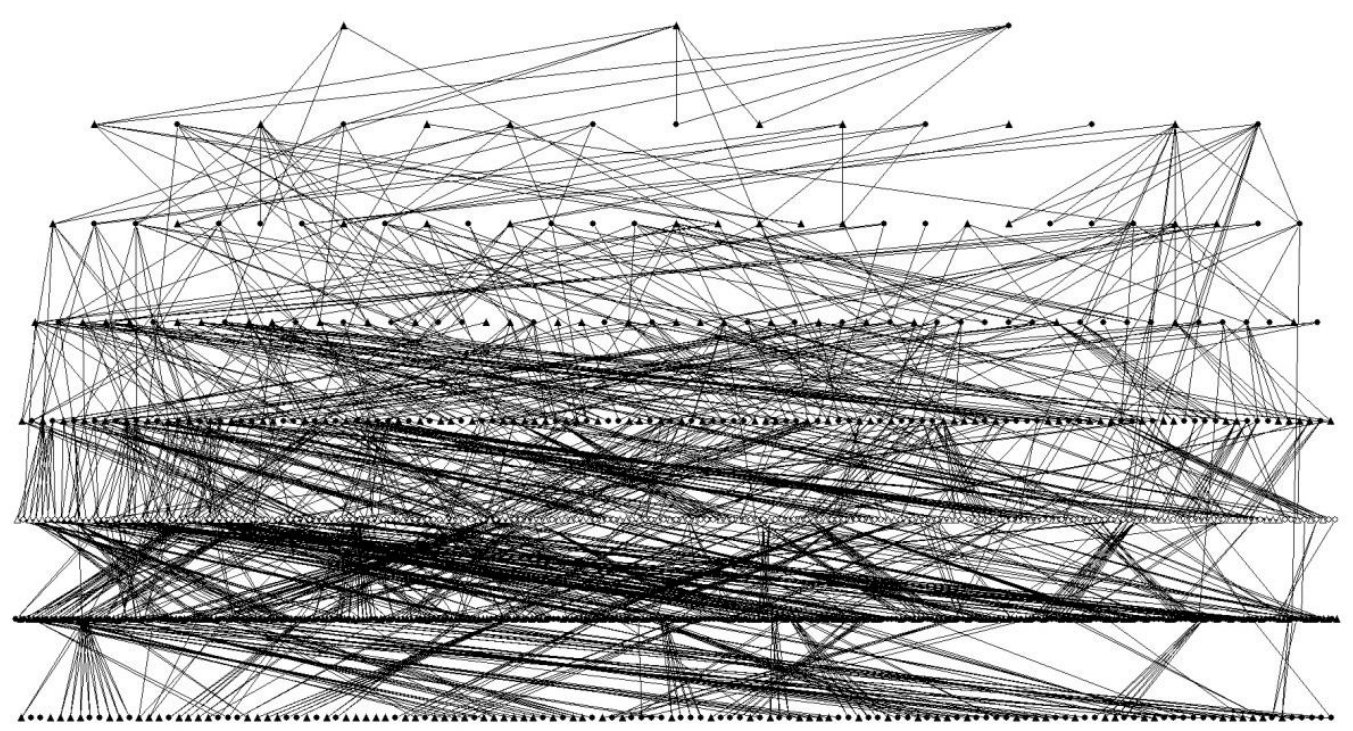

Podemos observar, a partir da análise do PUCK, que as relações de filiação apresentam uma distribuição desigual entre o estabelecimento de vínculos agnáticos (FCh, F-Ch-Ch, F-Ch-Ch-Ch...) e uterinos (M-Ch, M-Ch-Ch...) em relação às cadeias de filiação. A tabela e o gráfico a seguir marcam o prolongamento das cadeias de filiação através de laços maternos e paternos, indicando até a sexta relação de filiação. Vemos nela que a paternidade é lembrada mais do que a maternidade, mas, conforme aumenta a profundidade genealógica, os ancestrais femininos são mais recordados. A possibilidade de estabelecer linhas de filiação paterna, com grande profundidade, é menor do que as que envolvem, apenas, os vínculos de maternidade.

A constituição de linhas masculinas a partir dos vínculos imediatos diminui em relação aos vínculos femininos. Esse bias na memória não significa que os vínculos uterinos sejam mais relevantes, já que os esquecimentos podem ser mais importantes que as lembranças ${ }^{337}$. Esta memória dos vínculos de maternidade pode estar relacionada com a residência uxorilocal, pois as pessoas poderiam se lembrar mais das relações que envolveram os seus co-residentes.

\footnotetext{
${ }^{337}$ Veja discussão sobre memória no capítulo 1.
} 
Tabela 3 - Distribuição das linhas agnáticas e uterinas

\begin{tabular}{|c|c|c|c|c|}
\hline Distância & Indivíduos & Uterino & Agnático & A e U \\
\hline 1 & $805(92 \%)$ & $98.39 \%$ & $99.01 \%$ & $97.39 \%$ \\
\hline 2 & $709(81 \%)$ & $95.91 \%$ & $94.08 \%$ & $89.99 \%$ \\
\hline 3 & $583(66 \%)$ & $87.48 \%$ & $83.02 \%$ & $70.5 \%$ \\
\hline 4 & $377(43 \%)$ & $87.53 \%$ & $71.62 \%$ & $59.15 \%$ \\
\hline 5 & $196(22 \%)$ & $61.22 \%$ & $48.98 \%$ & $10.2 \%$ \\
\hline 6 & $45(5 \%)$ & $55.56 \%$ & $46.67 \%$ & $2.22 \%$ \\
\hline
\end{tabular}

Gráfico 1 - Relação entre memória de vínculos de filiação e profundidade geracional

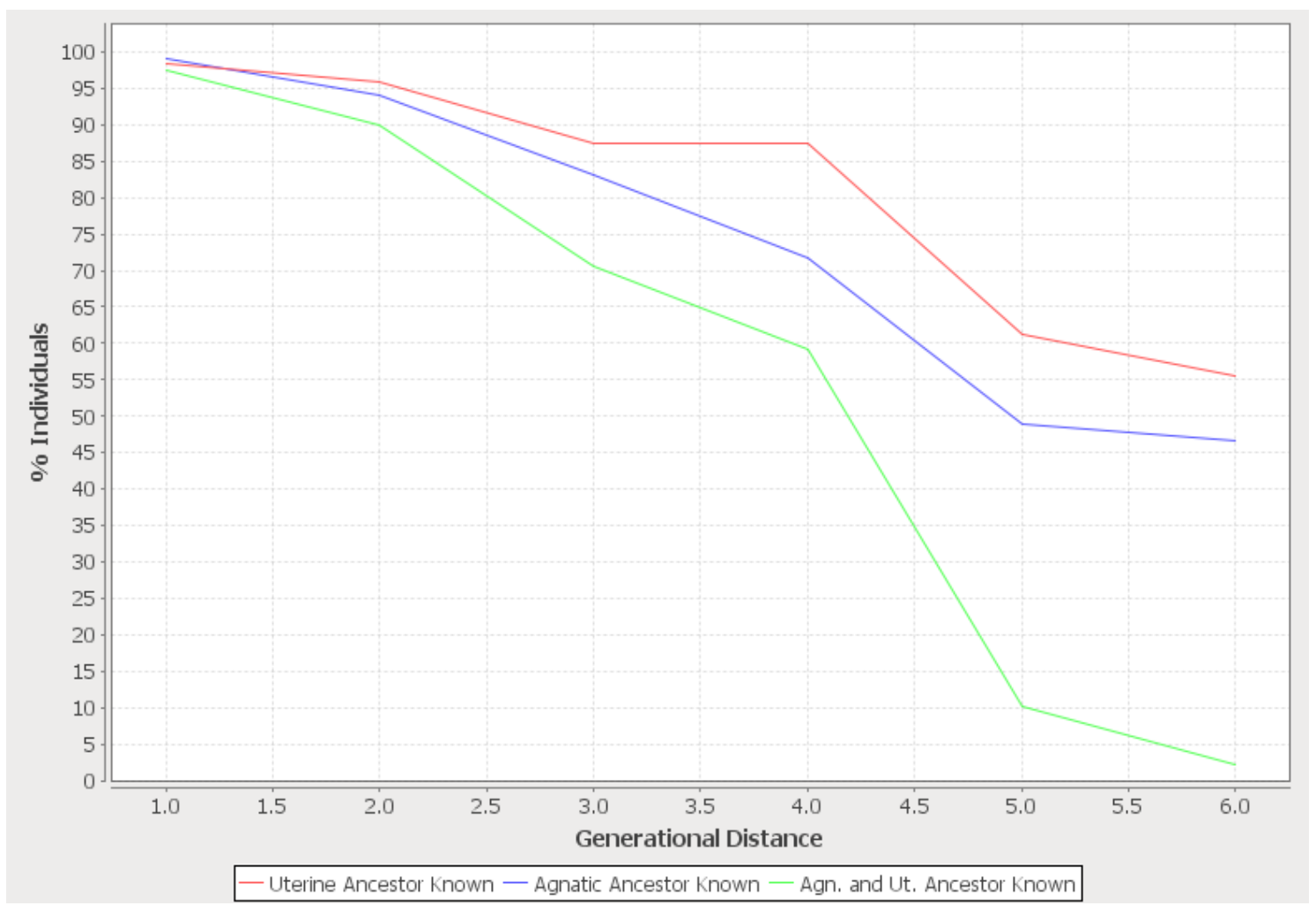

De um ponto de vista global, parece que a relevância das relações parentais diminui após o quarto vínculo de filiação, visto que há uma queda acentuada entre a $4^{\mathrm{a}} \mathrm{e}$ a $5^{a}$ geração. Só existem informações sobre a quinta geração ascendente $(\mathrm{G}+5)$ para $22 \%$ da população, sendo que apenas $10 \%$ possuem tanto vínculos agnáticos quanto uterinos. Embora, inicialmente, sejam as relações de um pai com seus filhos mais presentes na memória, há um esquecimento sistemático destes vínculos conforme há um afastamento em relação ao presente. Antes de explorarmos esta característica da rede, devemos apresentar algumas considerações sobre os casamentos que a compõem. 
Dispomos de informações sobre um total de 333 casamentos, que correspondem às uniões matrimoniais estáveis reconhecidas, mesmo que sem filhos, e as relações que se estabelecem entre o pai e a mãe de alguém. Considerar que os pais formam um casal não é uma escolha evidente, pois a paternidade poderia ser apenas fruto de um encontro casual, sem maiores consequências. No contexto Deni, contudo, atribuir a alguém a paternidade de uma pessoa estabelece um vinculo que será relevante para eventos subsequentes.

Dos 333 casamentos de nossa amostra, apenas 249 (74,77\%) contam com filhos, indicando uma baixa taxa de fertilidade que não corresponde ao que observamos durante nossa pesquisa. A taxa de infertilidade atual é de aproximadamente $10 \%$ dos casamentos com duração superior a cinco anos. Esta distorção entre a rede disponível e a observação empírica deve-se a três fatores: casamentos recentes ainda sem filhos; casamentos exogâmicos; casamentos do Xeruã. Nos casos exogâmicos, em que o Deni abandonou a vida entre seus parentes para morar com seu cônjuge não-Deni, comumente, não há informações sobre a existência de filhos. As informações sobre filhos para os casais do Xeruã também não são confiáveis, sendo assim, não podemos realizar análises que tomem a existência de filhos como parâmetro relevante.

No contexto Deni, mesmo os casamentos de curta duração têm consequências para os eventos subsequentes. Por exemplo, um homem não pode ter relações sexuais/matrimoniais com uma mulher com quem seu filho foi casado, mesmo que por apenas alguns meses. Os Deni casam e se separam muitas vezes, existindo muitas dessas breves uniões e, embora sejam relevantes, elas têm sua influência, nos casos em que não há filhos, restrita aos parentes próximos dos cônjuges, os únicos que parecem recordar estas ocorrências. A sua influência é restrita, pois, mesmo que em decorrência desses casamentos os pais não possam ter relações sexuais com os ex-cônjuges de seus filhos, isto não se estende para os irmãos dos pais.

Em nossa amostra, cada homem se envolveu em uma média de 1,26 casamentos e cada mulher em 1,21. Isto indica que, mesmo que seja possível para um homem desposar duas ou mesmo três mulheres ao mesmo tempo, a existência da poligamia não resulta em uma diferença significativa na quantidade de cônjuges para cada um dos sexos. Há uma grande quantidade de casos de poligamia entre os Deni, que não se restringem às pessoas de prestigio ou aos chefes. Eles são mais comum entre os homens velhos que, décadas após seu primeiro casamento, contraem um segundo matrimônio 
com uma mulher bem mais jovem que ele. Mesmo que os homens possam acumular mais esposas simultaneamente, há um maior número de mulheres que se tornaram viúvas ao longo da vida. Este fenômeno é percebido pelos próprios Deni que afirmam serem as mulheres mais duras (kharade ${ }^{338}$ ) que os homens e é, provavelmente, a causa da paridade no número de cônjuges para os diferentes sexos.

\section{3 - Linhas masculinas}

Como mostramos no capítulo 2, o pai e seus filhos fazem parte de uma mesma identidade, que decorre da concepção ocorrer, unicamente, pelo acúmulo de sêmen no corpo da mulher. Não parece existir uma elaboração da relação entre mãe e filhos dada pelo compartilhamento de leite materno, tal como ocorre entre os Kulina (Pollock 1984). Não há, entre os Deni, qualquer interdição sobre o compartilhamento do leite, tendo sido observados casos em que afins efetivos são amamentados (BW amamentando HZ) e isto tornaria contraditória uma relação entre aleitamento e consanguinidade. Estas identidades não são grupos sociais de qualquer tipo, mas algo que torna, de certa forma, as pessoas equivalentes, compartilhando algo que é semelhante entre seus corpos, ou seja, é uma parte da pessoa Deni (Da Matta \& Seeger \&Viveiros de Castro 1978) que não está contida em um corpo específico.

A relação entre pai e filho informa, nos dias de hoje, o pertencimento a uma das identidades_deni que, como mostramos no capítulo 3, podem ser utilizadas para estabelecer grandes diferenças entre pessoas que mantêm determinadas relações de parentesco, mas se comportamento de forma inapropriada. Pela observação direta, ao contrário do que ocorreria caso a fórmula nativa fosse consistentemente aplicada, é possível perceber que a distribuição destas identidades não é condizente com a aplicação de uma regra de descendência patrilinear ao longo de gerações, atuando inequivocamente apenas nas relações entre os vivos co-residentes. O único princípio atuante é o de que os filhos pertencem ao_deni do pai, porém, se não há contato com este ou ele não está vivo para reivindicar um pertencimento para si, é possível que não haja consenso entre seus filhos, o que resulta em siblings que afirmam pertencerem a diferentes "subgrupos".

\footnotetext{
${ }^{338}$ Kharade indica alguma coisa dura, resistente, que não é mole e não quebra facilmente. Para os Deni, crescer é um processo de endurecimento do corpo. Para uma discussão sobre isto veja Florido (2013).
} 
Temos, por um lado, um princípio cosmológico de que os filhos são formados pelo sêmen do pai e, portanto, seus corpos são semelhantes, mas, por outro lado, as identidades_deni não são consistentemente aplicadas entre pessoas distantes e ligadas por vínculos agnáticos. De nossa observação direta, parece que os irmãos que compartilham um mesmo pai são mais parentes (uvibuva) do que os que possuem apenas a mãe em comum, isto é, quando há um desentendimento entre irmãos, os que possuem o mesmo pai tendem a se apoiar contra o meio irmão materno. Iremos, portanto, realizar uma experiência com a genealogia Deni em que não levaremos em consideração as identidades_deni obtidas durante nossa pesquisa de campo, mas as que surgiriam em função da aplicação consistente da teoria Deni da concepção.

A identidade de sêmen não estabelece um recorte entre consanguíneos e afins (filhos, filhas e seus descendentes são igualmente consanguíneos), mas parece ter certa relevância na esfera matrimonial. Sua pertinência está condicionada as relações que a envolvem, tanto o esquecimento de certas paternidades, como mostramos acima a memória da paternidade é inversamente proporcional à profundidade genealógica, quanto os vínculos matrimoniais, parecem indicar sua existência empírica. Por um lado, algumas relações deixam de ser pertinentes e, por outro, as que estão presentes na memória parecem influenciar o regime matrimonial.

Realizamos a marcação dos indivíduos a partir de um ancestral masculino, com os qual eles estão ligados por vínculos de filiação paterna e, a partir disto, estabelecemos patrilinhas virtuais para verificar a relação entre estas identidades informadas pela cadeia seminal e o regime de alianças. Consideramos que cada um dos 45 homens sem pai conhecido, presentes na genealogia, gerava uma patrilinha que era transmitida através de descendência patrilinear. Os resultados deste procedimento apresentaram uma enorme variação, por um lado, surgiu uma identidade compartilhada por 190 pessoas (22\% do total), que corresponderia a quase o dobro da segunda mais comum, compartilhada por 101. Por outro lado, muitas das 45 possíveis linhas não possuiriam muitos descendentes, se limitando a um único homem, ou dois, ou três... Esses extremos forçaram a adoção de outros parâmetros e recortes.

Como mostramos anteriormente, as relações sexuais entre parentes paralelos (consanguíneos) têm consequências negativas para os envolvidos. Sendo assim, pessoas que compartilham um ancestral patrilinear não deveriam casar entre si. Dada esta características do regime de alianças Deni estas marcações deveriam corresponder a 
conjuntos exogâmicos, pois uma pessoa deveria ter relações sexuais/matrimoniais com indivíduos que não compartilham aspectos de seu corpo, isto é, que não são feitos do mesmo sêmen.

O maior conjunto passível de ser estabelecido, com 190 pessoas, parece superar a relevância destes vínculos, pois ele seria responsável por nove dos quatorze casos de endogamia de identidade patrilinear, sendo os outros cinco casos distribuídos entre diferentes agrupamentos, sem repetição. Após desconsiderar o ancestral mais longínquo deste grande conjunto, estabelecendo o inicio das linhas a partir de seus quatro filhos homens, esses nove casamentos endógamos desapareceram, ou seja, foi possível estabelecer o limite empírico da sua relevância: os descendentes de um ancestral com cinco gerações de profundidade. Esse limite é compatível com as informações de Koop \& Lingenfelter (1983) de que, a partir da quarta linha colateral, os parentes unidos por vínculos agnáticos deixam de ser consanguíneos, isto é, não casáveis e passam a ser contados como afins (casáveis).

Após esta quebra do maior conjunto, passaram a existir 48 marcações potenciais, porém, mais da metade delas contava com apenas uma (o homem ancestral), duas, três, quatro ou cinco pessoas. Para a análise, optamos por manter apenas as patrilinhas que eram compartilhadas por seis ou mais pessoas, isto é, possuíam uma distribuição mínima que permitiria observar a sua relação com as outras unidades. Os 25 conjuntos existentes após os recortes adotados são os seguintes: 


\begin{tabular}{|c|c|}
\hline \multicolumn{2}{|c|}{ Tabela 4 - Patrilinhas } \\
\hline Identidade & Número de indivíduos \\
\hline DN13 & 7 \\
\hline DN28 & 8 \\
\hline DN22 & 8 \\
\hline DN06 & 9 \\
\hline DN16 & 9 \\
\hline DN14 & 9 \\
\hline $\mathrm{BC01}$ & 11 \\
\hline DN04 & 11 \\
\hline DN05 & 12 \\
\hline DN03 & 12 \\
\hline QB03 & 15 \\
\hline DN20 & 15 \\
\hline DN33 & 16 \\
\hline $\mathrm{BCO2}$ & 23 \\
\hline DN01 & 24 \\
\hline DN32 & 25 \\
\hline DN25 & 26 \\
\hline DN02 & 35 \\
\hline DN10 & 45 \\
\hline DN19 & 46 \\
\hline QB01 & 74 \\
\hline DN17 & 79 \\
\hline DN11 & 80 \\
\hline QB02 & 97 \\
\hline DN23 & 101 \\
\hline otal de pessoas & 696 \\
\hline
\end{tabular}

As patrilinhas foram nomeadas por duas letras e dois números. Embora isto não seja relevante para a análise que realizamos, as letras indicam certas caraterísticas do primeiro ancestral: BC indica que são os descendentes de um homem não indígena; QB que fazem parte do conjunto cujo primeiro ancestral foi desconsiderado e; DN indica os descendentes a partir de um homem Deni cujo pai é desconhecido. Há, assim, duas identidades que surgiram a partir de um homem não Deni e 23 cujos ancestrais eram Deni, ou assim são reconhecidos atualmente ${ }^{339}$. Há agrupamentos potenciais que surgiriam a partir de homens Paumari, Kulina e Apurinã, porém não teriam um número suficiente de descendentes para serem relevantes neste experimento.

Há alguns conjuntos, como o DN13, cuja baixa representatividade é, provavelmente, fruto da alta taxa de mortalidade e/ou baixa fertilidade. Há outros, como o DN28 (8 pessoas), cujos homens casaram exogamicamente, abandonando a vida entre

\footnotetext{
${ }^{339}$ Nada impede que alguns desses homens fossem indígenas de outras populações que casaram em meio aos Deni, 50 - 60 anos atrás e, por isto, seus ancestrais são desconhecidos, bem como sua origem externa.
} 
os Deni, resultando na extinção da identidade por falta de homens na posição de pai. Há, por último, os casos que envolvem pessoas do Xeruã. De toda maneira, muitos desses pequenos agrupamentos poderiam ser fundidos em unidade maiores caso os seus vínculos fossem rememorados, mas não o são e, como mostramos anteriormente, esta é uma característica global da rede (o esquecimento dos vínculos de paternidade de forma proporcional a distancia genealógica).

Pessoas pertencentes a essas 25 marcações estão envolvidas em 266 casamentos da rede, ou seja, aproximadamente $80 \%$ do total. Os outros casamentos são os que envolvem homens sem muitos vínculos agnáticos e aqueles nos quais o sogro do homem (WF) não é conhecido. Organizados na sequência temporal temos: 
Gráfico 2 - Relações matrimoniais entre as patrilinhas

\begin{tabular}{|c|c|c|}
\hline Ano & $\mathrm{H}$ & W \\
\hline 1925 & QB01 & DN17 \\
\hline 1933 & DN19 & $\overline{D N 14}$ \\
\hline 1933 & DN23 & DN01 \\
\hline 1934 & DN01 & DN25 \\
\hline 1934 & DN23 & DN01 \\
\hline 1936 & DN23 & DN01 \\
\hline 1937 & DN33 & DNO1 \\
\hline 1937 & DN17 & DN01 \\
\hline 1939 & QB03 & DN14 \\
\hline 1939 & DN17 & DN14 \\
\hline 1939 & DN22 & DN25 \\
\hline 1941 & DN23 & DN01 \\
\hline 1943 & QB02 & DN17 \\
\hline 1943 & DN32 & DN14 \\
\hline 1944 & DN20 & DN25 \\
\hline 1945 & DN05 & $\overline{\text { DN11 }}$ \\
\hline 1947 & $\mathrm{BCO} 2$ & DN01 \\
\hline 1947 & DN04 & DN19 \\
\hline 1949 & DN23 & QB01 \\
\hline 1950 & QB02 & DN25 \\
\hline 1951 & DN02 & QB02 \\
\hline 1951 & QB02 & DN19 \\
\hline 1952 & DN11 & DN25 \\
\hline 1952 & DN25 & DN22 \\
\hline 1953 & DN01 & DN28 \\
\hline 1954 & DN14 & DN17 \\
\hline 1954 & DN01 & DN11 \\
\hline 1954 & DN11 & DN01 \\
\hline 1954 & DN17 & DN14 \\
\hline 1955 & QB01 & DN23 \\
\hline 1955 & DNO3 & QB02 \\
\hline 1956 & DN11 & DN25 \\
\hline 1956 & DN11 & DN28 \\
\hline 1957 & DN11 & DN33 \\
\hline 1957 & DN11 & DN33 \\
\hline 1958 & QB02 & DN23 \\
\hline 1959 & QB01 & DN28 \\
\hline 1959 & DN23 & QB03 \\
\hline 1959 & DN17 & QB02 \\
\hline 1959 & DN10 & DN33 \\
\hline 1960 & QB02 & DN05 \\
\hline 1960 & DN32 & DN13 \\
\hline 1962 & DN20 & DN25 \\
\hline
\end{tabular}

\begin{tabular}{|c|c|c|}
\hline 1963 & DN17 & DN32 \\
\hline 1963 & DN01 & DN05 \\
\hline 1967 & QB02 & DN01 \\
\hline 1967 & DN20 & DN25 \\
\hline 1968 & DNO1 & DN01 \\
\hline 1968 & DN25 & DN28 \\
\hline 1969 & DNO2 & DN11 \\
\hline 1969 & DN23 & QB03 \\
\hline 1969 & DN14 & DN14 \\
\hline 1969 & DN10 & DN23 \\
\hline 1970 & DN02 & DN01 \\
\hline 1970 & DN23 & DN10 \\
\hline 1970 & DN11 & DN33 \\
\hline 1970 & DN10 & DN33 \\
\hline 1971 & DN23 & DN11 \\
\hline 1972 & DN06 & DN28 \\
\hline 1973 & $\mathrm{BCO} 2$ & QB02 \\
\hline 1973 & QB02 & DN11 \\
\hline 1973 & DN25 & DN20 \\
\hline 1973 & DN20 & DN22 \\
\hline 1974 & DN19 & DN32 \\
\hline 1974 & QB02 & DN17 \\
\hline 1974 & DN22 & DN25 \\
\hline 1974 & DN13 & DN19 \\
\hline 1974 & DN11 & DN23 \\
\hline 1974 & $\mathrm{BC} 01$ & DN11 \\
\hline 1974 & QB02 & DN17 \\
\hline 1975 & QB01 & DN33 \\
\hline 1975 & DN23 & DN10 \\
\hline 1975 & DN17 & DNO2 \\
\hline 1975 & DN23 & QB01 \\
\hline 1975 & DN11 & QB02 \\
\hline 1975 & DN25 & DN33 \\
\hline 1975 & QB02 & DN32 \\
\hline 1976 & DN17 & DN14 \\
\hline 1976 & DN20 & DN33 \\
\hline 1976 & DN11 & DN28 \\
\hline 1977 & DN23 & DN11 \\
\hline 1977 & DN11 & QB02 \\
\hline 1977 & DN10 & DN33 \\
\hline 1977 & DN01 & DN11 \\
\hline 1978 & QB02 & DN11 \\
\hline 1978 & QB01 & DN32 \\
\hline 1978 & DN23 & QB01 \\
\hline
\end{tabular}

\begin{tabular}{|c|c|c|}
\hline 1978 & QB02 & DN17 \\
\hline 1978 & DN13 & QB02 \\
\hline 1978 & DN06 & DN01 \\
\hline 1978 & DN11 & DN23 \\
\hline 1978 & DN17 & DNO4 \\
\hline 1979 & DNO3 & QB01 \\
\hline 1979 & DN23 & DN11 \\
\hline 1979 & DN19 & DN23 \\
\hline 1979 & QB01 & DN17 \\
\hline 1979 & DN32 & DN19 \\
\hline 1979 & DN17 & DN02 \\
\hline 1979 & DN11 & DN10 \\
\hline 1979 & DN10 & DN11 \\
\hline 1979 & DN05 & DN11 \\
\hline 1979 & QB03 & DN17 \\
\hline 1980 & QB02 & DN23 \\
\hline 1980 & QB02 & DN22 \\
\hline 1980 & DN10 & QB01 \\
\hline 1980 & DN10 & DN11 \\
\hline 1980 & DNO2 & DN11 \\
\hline 1981 & DN02 & DN10 \\
\hline 1981 & DN23 & DN11 \\
\hline 1981 & DN23 & QB02 \\
\hline 1982 & DN14 & QB02 \\
\hline 1982 & DN11 & DN25 \\
\hline 1983 & DN20 & QB02 \\
\hline 1983 & DN11 & DN10 \\
\hline 1983 & DN25 & DN20 \\
\hline 1983 & DN23 & DN11 \\
\hline 1983 & DN10 & DN11 \\
\hline 1984 & QB02 & QB03 \\
\hline 1984 & DN11 & DN10 \\
\hline 1985 & DNO2 & QB01 \\
\hline 1985 & QB01 & DN10 \\
\hline 1986 & DN32 & QB01 \\
\hline 1986 & DN01 & DN11 \\
\hline 1988 & DN10 & DN17 \\
\hline 1988 & DN17 & DN32 \\
\hline 1988 & QB01 & DN17 \\
\hline 1988 & DN06 & DN10 \\
\hline 1989 & QB02 & DN17 \\
\hline 1989 & DN06 & DN23 \\
\hline 1990 & DN22 & DN20 \\
\hline 1990 & $\mathrm{BCO} 2$ & QB02 \\
\hline
\end{tabular}




\begin{tabular}{|l|l|l|}
\hline 1991 & QB02 & DN17 \\
\hline 1991 & QB01 & DN11 \\
\hline 1992 & DN23 & QB01 \\
\hline 1992 & DN23 & QB01 \\
\hline 1992 & BC01 & DN17 \\
\hline 1992 & DN04 & QB02 \\
\hline 1992 & QB02 & DN11 \\
\hline 1992 & DN23 & DN11 \\
\hline 1992 & DN06 & DN33 \\
\hline 1992 & DN17 & DN13 \\
\hline 1992 & DN17 & DN32 \\
\hline 1992 & QB02 & DN17 \\
\hline 1992 & DN25 & DN06 \\
\hline 1993 & QB01 & QB02 \\
\hline 1993 & DN10 & DN06 \\
\hline 1993 & DN10 & QB02 \\
\hline 1994 & DN02 & QB02 \\
\hline 1994 & DN10 & DN23 \\
\hline 1994 & DN22 & DN25 \\
\hline 1994 & DN10 & DN16 \\
\hline 1995 & DN05 & DN11 \\
\hline 1995 & DN01 & DN03 \\
\hline 1995 & DN25 & DN33 \\
\hline 1995 & DN25 & DN20 \\
\hline 1996 & QB01 & DN23 \\
\hline 1996 & QB01 & DN17 \\
\hline 1996 & DN23 & DN11 \\
\hline 1996 & DN02 & DN33 \\
\hline 1996 & DN16 & QB01 \\
\hline 1996 & DN02 & QB01 \\
\hline 1996 & DN20 & DN25 \\
\hline 1997 & QB01 & DN23 \\
\hline 1997 & DN11 & DN23 \\
\hline 1997 & DN17 & DN19 \\
\hline 1997 & DN17 & DN13 \\
\hline 1997 & DN10 & DN10 \\
\hline 1997 & DN02 & DN11 \\
\hline 1998 & DN23 & DN32 \\
\hline 1998 & BC02 & QB01 \\
\hline 1998 & DN11 & DN05 \\
\hline 1998 & DN02 & DN11 \\
\hline & QB02 & BC02 \\
\hline DN25 & DN02 \\
\hline 1998 & DN17 \\
\hline 1998 & \\
\hline 1982 & &
\end{tabular}

\begin{tabular}{|l|l|l|}
\hline 1999 & QB01 & BC02 \\
\hline 1999 & DN23 & DN03 \\
\hline 1999 & DN19 & DN03 \\
\hline 1999 & QB01 & DN14 \\
\hline 1999 & QB02 & DN11 \\
\hline 2000 & DN23 & QB01 \\
\hline 2000 & QB01 & QB03 \\
\hline 2001 & BC02 & DN10 \\
\hline 2001 & DN11 & DN01 \\
\hline 2001 & DN11 & DN02 \\
\hline 2001 & DN23 & QB02 \\
\hline 2002 & QB02 & QB01 \\
\hline 2002 & DN23 & QB01 \\
\hline 2002 & DN02 & DN14 \\
\hline 2002 & DN10 & DN23 \\
\hline 2002 & DN23 & DN11 \\
\hline 2002 & DN19 & QB02 \\
\hline 2002 & DN17 & QB01 \\
\hline 2002 & DN19 & DN23 \\
\hline 2002 & DN19 & DN32 \\
\hline 2002 & QB01 & DN23 \\
\hline 2003 & QB01 & QB02 \\
\hline 2003 & DN23 & QB01 \\
\hline 2003 & DN19 & DN23 \\
\hline 2003 & DN23 & DN19 \\
\hline 2003 & DN17 & QB02 \\
\hline 2003 & DN11 & DN11 \\
\hline 2003 & DN11 & DN02 \\
\hline 2003 & DN23 & DN11 \\
\hline 2003 & BC02 & QB02 \\
\hline 2003 & DN19 & QB01 \\
\hline 2003 & QB02 & DN23 \\
\hline 2004 & QB03 & QB01 \\
\hline 2004 & DN23 & QB02 \\
\hline 2004 & QB02 & DN17 \\
\hline 2004 & DN23 & DN23 \\
\hline 2004 & DN13 & DN19 \\
\hline 2004 & DN17 & DN32 \\
\hline 2004 & DN32 & QB01 \\
\hline 2004 & DN32 & DN17 \\
\hline QB01 & DN17 \\
\hline DN11 & DN23 \\
\hline DN02 & DN06 \\
\hline DN23 & QB01 \\
\hline
\end{tabular}

\begin{tabular}{|l|l|l|}
\hline 2006 & QB01 & DN23 \\
\hline 2007 & DN23 & DN19 \\
\hline 2007 & DN17 & QB02 \\
\hline 2007 & QB02 & DN01 \\
\hline 2007 & QB03 & BC02 \\
\hline 2007 & DN19 & DN17 \\
\hline 2007 & DN32 & DN17 \\
\hline 2007 & QB01 & DN03 \\
\hline 2007 & DN11 & DN23 \\
\hline 2007 & DN23 & QB02 \\
\hline 2007 & BC02 & QB02 \\
\hline 2008 & DN17 & DN04 \\
\hline 2008 & BC01 & QB01 \\
\hline 2008 & DN23 & DN11 \\
\hline 2008 & DN23 & QB02 \\
\hline 2008 & QB03 & DN17 \\
\hline 2008 & DN16 & DN23 \\
\hline 2009 & QB02 & DN23 \\
\hline 2009 & BC01 & QB01 \\
\hline 2009 & DN19 & QB02 \\
\hline 2009 & DN02 & DN23 \\
\hline 2009 & DN11 & QB02 \\
\hline 2009 & DN23 & DN02 \\
\hline 2009 & DN32 & DN19 \\
\hline 2009 & DN03 & QB01 \\
\hline 2009 & QB01 & DN23 \\
\hline 2009 & QB02 & DN17 \\
\hline 2009 & DN23 & DN03 \\
\hline 2009 & DN25 & DN01 \\
\hline 2009 & DN05 & DN10 \\
\hline 2010 & DN17 & QB02 \\
\hline 2010 & QB01 & DN17 \\
\hline 2010 & DN03 & QB01 \\
\hline 2010 & QB01 & QB02 \\
\hline 2010 & DN10 & DN23 \\
\hline 2010 & QB02 & DN32 \\
\hline 2010 & QB02 & DN23 \\
\hline 2011 & DN23 & DN03 \\
\hline DN17 & QN02 & QB01 \\
\hline
\end{tabular}


Adotamos cores para as casas e as letras apenas para facilitar a visualização, sem ter nenhum significado atribuído. Podemos perceber que as identidades com poucos membros correspondem a casos heterógenos: espalhados temporalmente, concentrados, uma desproporção entre a posição de esposa e a de marido. Vemos, também, que os casos de endogamia envolvendo dois dos grandes conjuntos (DN11 e DN23) aconteceram nos últimos 10 anos, isto é, na última geração, sugerindo que os primeiros vínculos estão no limiar de perder sua relevância.

Muitas das pessoas que receberam uma marcação patrilinear seminal não participam de nenhum dos casamentos representados no gráfico acima, isto é, a quantidade de vezes elas aparecem na posição de cônjuge é inferior ao total das pessoas marcadas. Isto ocorre porque algumas pessoas não casaram, ou seus sogros são desconhecidos, ou envolviam as patrilinhas que foram deixadas de fora após o primeiro recorte estabelecido. Devemos proceder a uma nova seleção, estringindo a análise aos conjuntos que estão envolvidos em certo número de relações matrimoniais.

A partir da quantidade de maridos $(\mathrm{H})$ e esposas ${ }^{340}(\mathrm{~W})$, recortamos os conjuntos de forma a garantir que eles mantivessem um número mínimo de vínculos. Como é possível ver na tabela abaixo, a partir da $5^{\mathrm{a}}$ marcação mais comum, há uma queda acentuada e, por isso, nos deteremos na análise das relações entre as cinco maiores. Esperamos, com isso, poder apreender certos padrões que não poderiam ser percebidos caso focássemos nos conjuntos que se envolvem em poucos eventos matrimoniais.

\footnotetext{
${ }^{340}$ Não se trata da quantidade de pessoas, pois estas podem estar envolvidas em mais de um casamento. Nosso foco recai sobre o evento matrimonial, cada um deles gerando um marido e uma esposa nos dados.
} 
Tabela 5 - Quantidade de cônjuges por identidade e local

\begin{tabular}{|c|c|c|}
\hline Marcação & Cônjuges & Concentração das pessoas vivas $^{341}$ \\
\hline DN23 & $40 \mathrm{H} / 30 \mathrm{~W}^{342}$ & Viagem - Volta Grande - Sikuriha ${ }^{343}-$ Samauma \\
\hline QB02 & $32 \mathrm{H} / 32 \mathrm{~W}$ & Marrecão - Cidadezinha \\
\hline DN11 & $26 \mathrm{H} / 30 \mathrm{~W}^{344}$ & Samauma - Sikuriha \\
\hline DN17 & $21 \mathrm{H} / 25 \mathrm{~W}$ & Marrecão - Cidadezinha \\
\hline QB01 & $26 \mathrm{H} / 26 \mathrm{~W}$ & Viagem - Cidadezinha \\
\hline DN19 & $11 \mathrm{H} / 9 \mathrm{~W}$ & Marrecão \\
\hline DN10 & $16 \mathrm{H} / 11 \mathrm{~W}^{345}$ & Xeruã \\
\hline
\end{tabular}

Os sete maiores conjuntos estão envolvidos em 228 dos 266 casamentos, ou seja, participam de $85 \%$ do total de casamentos com cônjuges marcados, sendo que, quando consideramos apenas os cinco maiores, eles estão envolvidas em 192 uniões, 72\%. Há uma desproporção entre maridos e esposas, sendo mais regular a frequência dos casamentos que envolvem as mulheres dos conjuntos. Na tabela abaixo, as linhas correspondem à identidade do homem e a coluna a da mulher, ou seja, uma leitura na horizontal permite ver com quem os homens de determinado conjunto contraíram matrimônio e na vertical é possível ver isto para as mulheres.

Tabela 6 - Os eventos matrimoniais entre as cinco maiores patrilinhas

\begin{tabular}{|c|c|c|c|c|c|c|}
\hline W & DN23 & QB02 & DN11 & DN17 & QB01 & $\begin{array}{c}\text { Total } \\
\text { (proporção) }\end{array}$ \\
\hline DN23 & 1 & 5 & 10 & $\backslash$ & 9 & $25(63 \%)$ \\
\hline QB02 & 5 & & 4 & 10 & 2 & $21(67 \%)$ \\
\hline DN11 & 6 & 3 & 1 & $\backslash$ & $\backslash$ & $10(38 \%)$ \\
\hline DN17 & $\backslash$ & 4 & $\backslash$ & & 1 & $5(23 \%)$ \\
\hline QB01 & 7 & 4 & 1 & 6 & $18(69 \%)$ \\
\hline $\begin{array}{c}\text { Total } \\
\text { (proporção) }\end{array}$ & $\begin{array}{c}19 \\
(63 \%)\end{array}$ & $\begin{array}{c}16 \\
(50 \%)\end{array}$ & $\begin{array}{c}16 \\
(53 \%)\end{array}$ & $\begin{array}{c}16 \\
(64 \%)\end{array}$ & $\begin{array}{c}12 \\
(46 \%)\end{array}$ & $\begin{array}{c}79 \text { casamentos } \\
\left(41 \% \%^{346}\right)\end{array}$ \\
\hline
\end{tabular}

\footnotetext{
341 Aqui, fica evidente a distorção causada pela pesquisa de campo ter sido desenvolvida na aldeia Cidadezinha. A maior patrilinha virtual, subdividida em QB01 e QB02, é aquela que envolve seus moradores.

${ }^{342}$ Há, aqui, um caso de endogamia.

343 Viagem, Volta Grande e Sikuriha surgiram de cisões a partir de uma aldeia original, sendo que algumas pessoas foram para o Samauma após a divisão.

${ }^{344}$ Há, aqui, um caso de endogamia.

${ }^{345}$ Há, aqui, um caso de endogamia.

$34641 \%$ do total de casamentos em que estão envolvidas as cinco maiores identidades.
} 
De uma maneira geral, podemos perceber que a parcela das uniões que envolvem mulheres destas patrilinhas e os homens de outras varia entre $46 \%$ e $64 \%$ do total possível, já para os homens o intervalo é maior, sendo que estes se casam entre $23 \%$ e $69 \%$ das vezes com mulheres dos conjuntos. As mulheres tendem a casar mais frequentemente com um cônjuge das cinco maiores identidades, o mesmo não sendo válido para os homens, que podem, ou não, estar mais envolvidos nas trocas do que as mulheres. Isto é, provavelmente, reflexo da regra de residência uxorilocal, já que a maior mobilidade masculina permite que eles contraiam matrimônio em outros locais, muitos dos quais não puderam ser contemplados na pesquisa de campo.

As relações matrimoniais são mais frequentes entre algumas destas patrilinhas do que entre outras, sendo raras ou mesmo inexistentes entre algumas delas. DN23 e DN17, DN11 e DN17 não casam entre si e entre DN11 e QB01 há apenas uma união. Isto é reflexo do afastamento geográfico entre seus membros, pois DN23 e DN11 estão localizados no alto Cuniuá, tendo suas relações voltadas para o Xeruã, pouco se relacionando com os moradores das aldeias Cidadezinha e Marrecão, em que se encontram os descendentes e ancestrais recentes de DN17. De maneira geral, as relações matrimoniais são mais comuns entre as identidades que, atualmente, estão geograficamente próximas, reflexo de uma história recente compartilhada. Aquelas que realizaram trocas matrimoniais em algum momento tendem, contudo, a repeti-las periodicamente.

Os casamentos se desenvolvem no tempo, sendo assim, precisamos considerar também esta dimensão. Na tabela abaixo, que deve ser lida na vertical, apresentamos a distribuição destes eventos numa sequência temporal. Separamos os pares de identidades nas colunas e, dada a existência de certa imprecisão na datação dos casamentos recuados no tempo, eles foram agrupados por décadas. Não foram incluídos os casos de endogamia de DN11 ocorrido em 2003 e de DN23 em 2004, não sendo, também, representado o único casamento entre um homem QB02 e uma mulher DN11, concretizado em 1991.

Gráfico 3 - Trocas matrimoniais entre as maiorias patrilinhas 


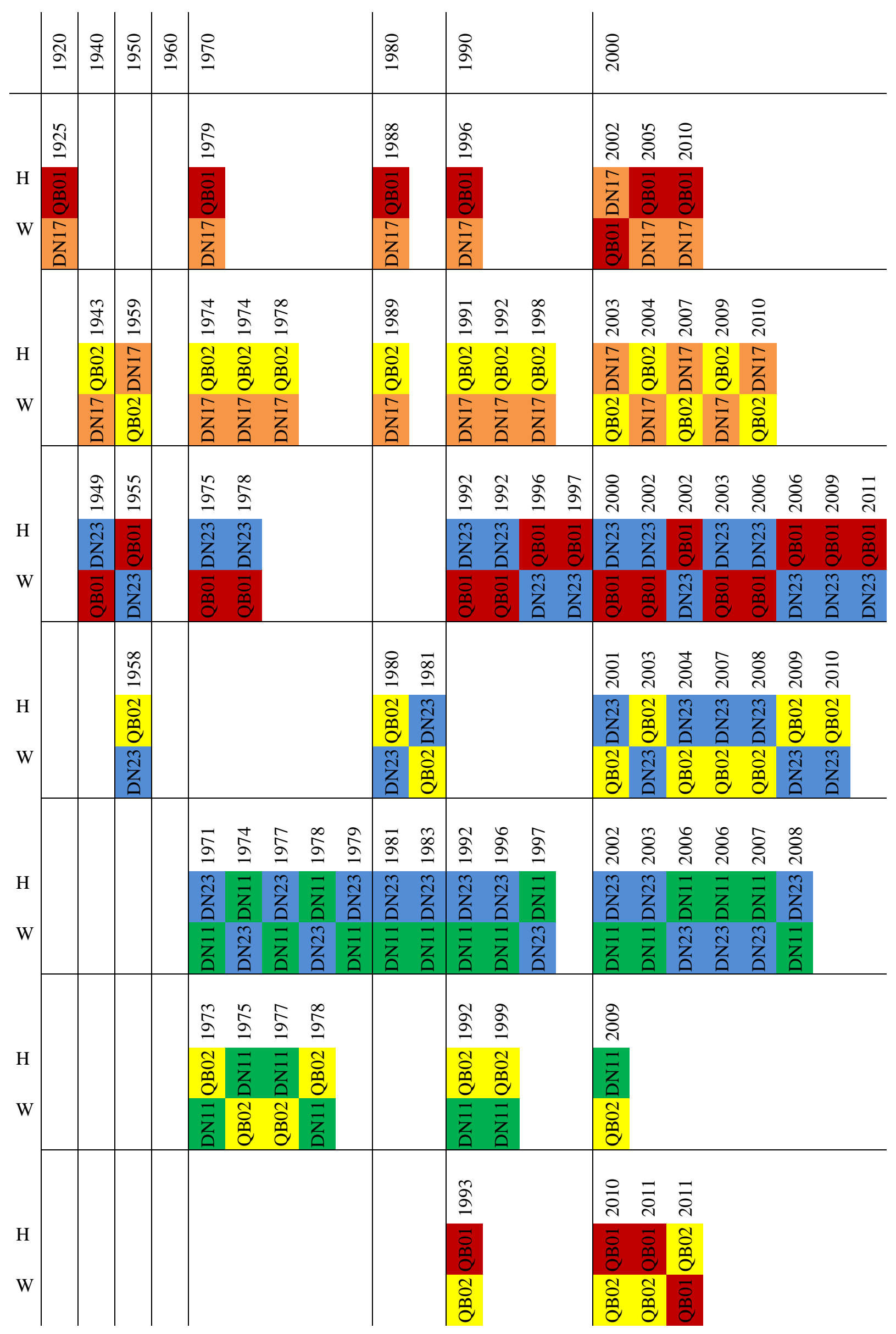


Há algumas regularidades nas relações entre as diferentes linhas, não parecendo que os eventos matrimoniais ocorram aleatoriamente. Há, em geral, dois períodos distinguíveis de relacionamento: um em que ocorrem trocas, isto é, em que homens e mulheres de ambas casam entre si; e outro, que pode durar décadas, em que os homens de uma casam sistematicamente com as mulheres da outra. $\mathrm{O}$ fluxo de maridos nunca se inverte, embora pareça que isto ocorra nos anos mais recentes, há, nos anos 2000, uma maior quantidade de eventos em um curto período de tempo, assim, trocas podem parecer fluxos unidirecionais pela repetição em sequência de um tipo de união.

Os Deni praticam residência pós-marital uxorilocal, ou seja, o homem muda-se para a casa/aldeia dos parentes de sua esposa. Isto não implica que o fluxo de homens entre as linhas corresponda ao deslocamento de uma série de homens de uma aldeia para determinada localidade em que estão as mulheres, pois, embora a residência do marido seja a da esposa, seus descendentes são de sua patrilinha e podem casar na mesma aldeia que seu pai, com mulheres da patrilinha de sua mãe. De qualquer maneira, o único fluxo que parece perdurar por muitos anos é aquele de homens QB01 + QB02 (distinção que só é relevante nos anos recentes) para mulheres DN17, que perdura por três décadas, torando-se trocas regulares apenas neste século.

O conjunto DN17 parece ter uma posição marginal, pois suas relações não são estendidas para DN11 e DN23. Se atentarmos para os números, a menor parte dos homens DN17 (23\%) participa das trocas matrimoniais entre as identidades enfocadas.

Figura 13 - Relação de trocas entre as patrilinhas

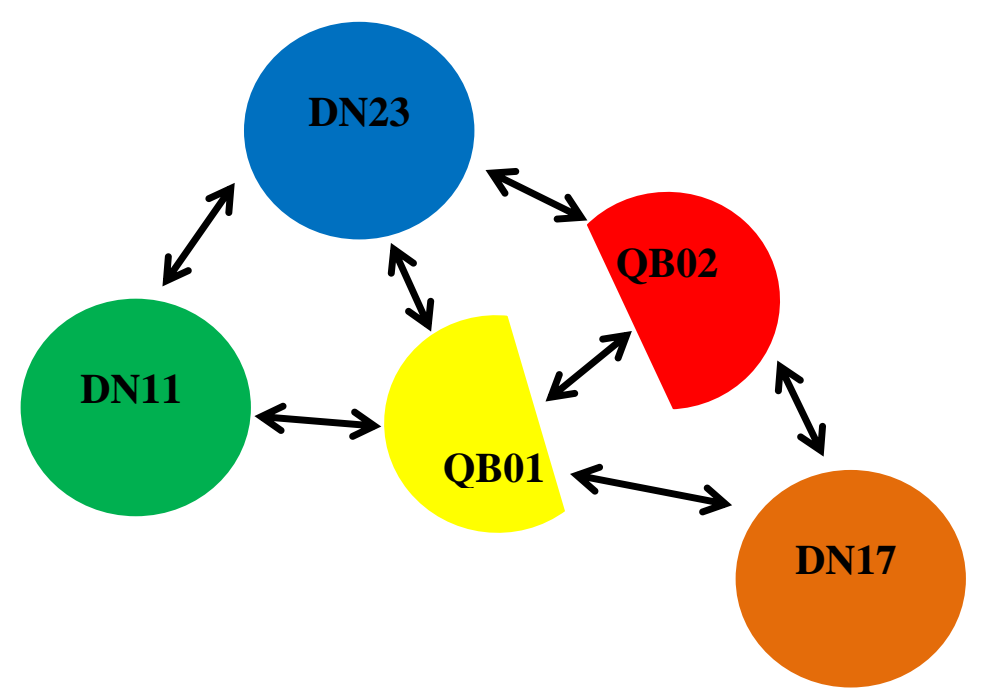


A maior parte dos homens DN17 se envolve em relações matrimoniais com outras patrilinhas, algumas das quais se vinculam com DN23 e DN11. Elas são, contudo, fragmentos de identidade potencialmente maiores, mas, como já apontamos, só o "Nós" (capítulo 1) possui uma existência na memória. Isto fica evidente ao considerarmos que a patrilinha (QB01 + QB02) mais representada na Cidadezinha, cujos ancestrais puderam ser registrados de forma mais completa, ocupa a posição central, trocando com todas as outras.

Mesmo os fluxos de homens de uma linha em direção a outra são antecedidos e sucedidos por períodos de troca em que homens de ambas casam-se com mulheres da outra. A relação entre os diferentes conjuntos está colocada desde quase o limite da memória, possuindo grande profundidade temporal. Apenas as uniões matrimoniais ocorridas entre partes (QB01 e QB02) de uma patrilinha surgem em anos recentes, provavelmente porque, anteriormente, os vínculos seriam relevantes, mas deixaram de ser na época destes casamentos. Não ocorre, também, o isolamento entre elas após o inicio do contato, se existiram inter-casamentos, mesmo que haja certos períodos sem fluxos de cônjuges, a aliança entre elas é reforçada ao longo do período.

Lembramos que essas patrilinhas não correspondem a unidades sociocêntricas de qualquer tipo, elas têm uma realidade informada pela aplicação do modelo Deni de identidade e constituição da pessoa. Há uma tendência a exogamia de um "Nós", isto é, aqueles que seriam inegavelmente os uvibuva, compostos por um mesmo sêmen e que provavelmente possuem cheiro $\left(m a h u^{347}\right)$ semelhante, não casam entre si. Quando há casamentos, estes são evidência de que o nosso registro superou a relevância prática dos vínculos. A exogamia baseada na constituição corporal, mas que não é formulada explicitamente nestes termos, parece ser um parâmetro muito importante, pois sua aplicação parece ser superior aos demais.

O recorte que adotamos permitiu perceber certas relações entre as patrilinhas, porém o que temos é um resultado global, aplicável de maneira restrita. Já apontamos que, muitas das linhas passíveis de serem estabelecidas a partir de nossos dados correspondem, provavelmente, a partes de conjuntos maiores, cuja memória dos ancestrais não foi acessada durante a pesquisa de campo. Podemos, apenas, imaginar que os esquecimentos ocorrem de forma a manter os casos de endogamia fora da memória. Durante o processo de construção desses dados, era evidente que, em alguns

${ }^{347}$ Veja capítulo 3. 
momentos, a narrativa de determinada pessoa gerava recortes (esquecimentos) distintos daqueles que outra pessoa fazia, ao ponto de alguns negarem que certos cônjuges de ancestrais, principalmente homens, eram originalmente madiha, enquanto outros falavam sobre sua ascendência Deni.

Por exemplo, um homem (DN17), morador da aldeia Cidadezinha, apontava que dois irmãos (DN14), que contraíram matrimônio na aldeia onde ele nasceu (nos anos 1940), não eram Deni. No curso da pesquisa, contudo, entramos em contato com moradores de outras localidades que possibilitaram o estabelecimento dos vínculos genealógicos desses dois irmãos com outros madiha. A questão relevante é que os Outros formam, sempre, uma massa indistinta ${ }^{348}$ e estes casamentos ocorreram antes do surgimento da noção de que todos os Deni são uma mesma coisa.

A questão toda parece ser que, do ponto de vista global, a paternidade é mais importante que a maternidade, pois há uma maior lembrança dos vínculos de paternidade do que de maternidade. Se, por um lado, a relação de filiação paterna é recordada com mais frequência, por outro, ela é mais facilmente esquecida com a profundidade genealógica. Estes esquecimentos parecem estar em função da falta de importância de manter uma memória sobre os que não fazem parte do "Nós", os madiha. A ligação destes homens com outras pessoas já falecidas, cujos descendentes moram em outra aldeia, torna estes vínculos irrelevantes para o conhecimento genealógico deste senhor.

As cinco patrilinhas que focalizamos abrangem 431 pessoas, ou seja, quase $50 \%$ do total de 875 indivíduos que compõem a genealogia fazem parte de uma delas. Os casos de endogamia ocorreram, todos, em anos recentes, o que indicaria uma tendência a exogamia de linha paterna, mas que possui um limite de relevância temporal, pois, a partir de certo ponto, ocorrem uniões dentro do conjunto. Isto contraria o modelo nativo, ou mesmo aquele formulado por alguns antropólogos, no que diz respeito à endogamia de subgrupo_deni. Vemos com isso que, como sugerimos no capitulo 2, esta é uma identificação que originalmente teria um significado exclusivamente territorial, passando a estar relacionada com a identidade de tipo _madi, que seria constituída por diferenças corporais e provavelmente estaria ligada a teoria da concepção, apenas em época recente.

\footnotetext{
${ }^{348}$ Veja capítulo 2.
} 
Se as pessoas são formadas, como parece ser o caso para os Deni, unicamente pelo sêmen e, como afirmam, o "subgrupo" (_deni) é transmitido por via paterna, a endogamia de patrilinhas deveria ser um evento mais comum no plano empírico do que efetivamente é, pois as patrilinhas corresponderiam aos "subgrupos" e, segundo afirmam os Deni, eles correspondiam ao limite da endogamia. Como já apontamos, do universo total de 333 casamentos, apenas 14 seriam endogâmicos se aplicássemos indistintamente o modelo Deni, ou seja, aproximadamente $4 \%$ e, mesmo se considerarmos somente os 266 casamentos em que é possível atribuir as patrilinhas dos dois cônjuges, apenas 5\%, seriam endogâmicos. Quando realizamos o desmembramento da maior patrilinha (QB01, QB02, QB03) a partir do limite de relevância da cadeia de filiação paterna, apenas $1 \%-2 \%$ das uniões ocorrem entre pessoas da mesma patrilinha. Os ciclos de troca entre as linhas paternas seriam condizentes com a endogamia de "subgrupo"_deni se este fosse um grupo de filiação local, pois, os homens que casam em um local com predomínio de determinado conjunto, geram homens que se casam novamente no local de predomínio deste.

Embora os percentuais de endogamia e exogamia de patrilinha pareçam apoiar as conclusões que estamos apresentando, devemos levar em conta que nem todos os 333 casamentos ocorrem entre pessoas que possuiriam um vínculo genealógico reconhecido. Há, nos dados, 14 casamentos entre um homem não-Deni e uma mulher Deni, isto é, os casamentos em que há uma exogamia máxima são tão frequentes quanto os que seriam endogâmicos. Nessas uniões exogâmicas, o matrimônio ocorreu com os não parentes (não uvibuva), entre os quais estão tanto alguns não indígenas (kariva), quanto Kulina, Paumari, Apurinã (os quase uvibuva).

Os dados sobre os descendentes destas uniões exogâmicas são fragmentários, pois há casos em que as mulheres abandonaram a vida na TI Deni e uma parte significativa ocorreu na região do Xeruã. A rede que estamos analisando possui apenas 50 pessoas que descendem, exclusivamente por vínculos de paternidade, de um homem não-Deni (incluso os 14 maridos não-Deni) e participam de apenas dois dos conjuntos com mais do que cinco pessoas (BC01 e BC02). Não podemos, portanto, realizar considerações detalhadas sobre como seriam integrados no esquema de trocas entre identidades patrilineares.

A endogamia de identidade patrilinear corresponde a um tipo de casamento consanguíneo em que é possível estabelecer a existência de um ancestral comum para os 
cônjuges, mas a ligação genealógica entre eles está limitada aos laços de filiação paterna, ou seja, ela representa um caso dentro outros em que é possível traçar um vínculo genealógico entre os cônjuges. Entre duas pessoas que possuem um ancestral comum é possível estabelecer ligações que passam tanto por pais e mães quanto por filhos e filhas, então, devemos levar em consideração todas essas possibilidades para ver se a raridade deste tipo de endogamia é relevante ou não. Para tanto vamos considerar todos os casamentos consanguíneos, isto é, todas as uniões matrimoniais que envolvem duas pessoas genealogicamente relacionadas e, desta forma, poderemos observar se a exogamia de patrilinha é relevante ou não.

\section{4 - Casamentos consanguíneos}

Realizamos a decomposição da rede Deni, utilizando o MaqPar, para que pudéssemos apreender os enlaces consanguíneos, ou bouclage (Françoise Héritier 1981), presentes na rede, isto é, observar os casamentos nos quais podemos traçar uma relação entre os cônjuges passando, exclusivamente, por laços consanguíneos: F, M, S, D. Não se tratam de casamentos em que marido e esposa são considerados, necessariamente, como consanguíneos pelos Deni, mas, sim, daqueles em que há a memória de um vínculo genealógicos formado por duas cadeias de filiação que partem

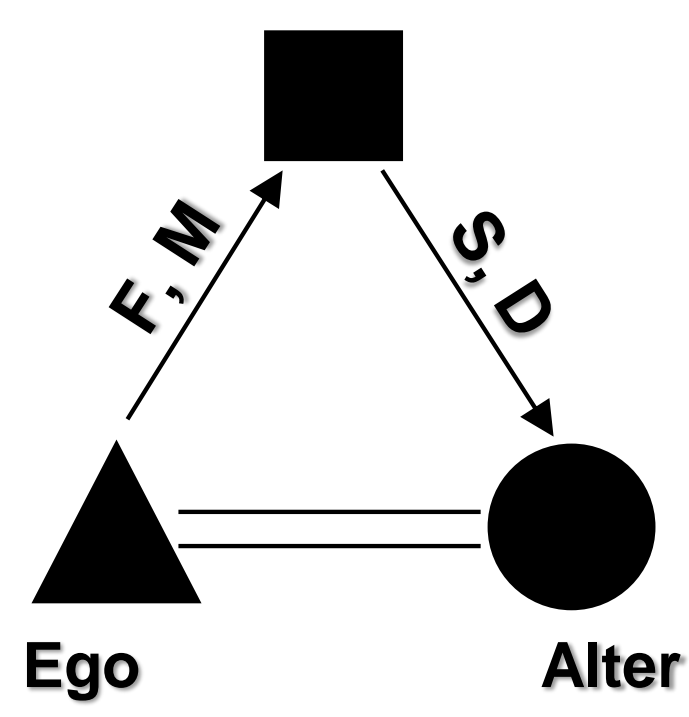

Figura 14 - Anel A1C1 de um ancestral comum ao casal. Este é anel de rede é chamado A1C1 pelos pesquisadores que têm realizado este tipo de investigação (Dal Poz \& Silva 2008 e 2010, Bueno 2008, Maizza 2012, Silva 2012) e corresponde a figura ao lado.

Os anéis $\mathrm{A} 1 \mathrm{C} 1$ da rede Deni $^{349}$ são compostos por uma relação de casamento e uma sequência consanguínea que parte do marido e passa por relações de paternidade e maternidade ( $\mathrm{F}$ ou $\mathrm{M})$

\footnotetext{
${ }^{349}$ Os anéis $\mathrm{A} 1 \mathrm{C} 1$ da rede Deni são deste tipo, pois não há registros de casamentos entre parentes lineares. Como chama a atenção Silva, este nem sempre é o caso, pois as "cadeias consanguíneas podem subir (FFFMMM, etc.), descer (DDDSSS, etc.) ou subir até um parente apical e descer (MMFFSSDD, etc.)" (grifos do autor - 2012: 46).
} 
até atingir um ancestral comum, quando continua através de relações de filiação ( $\mathrm{S}$ ou D) até a esposa. Para a análise, o anel é decomposto em um percurso, ou cadeia, que parte sempre de um Ego masculino ${ }^{350}$ e atinge um Alter feminino.

Há 159 casamentos nos quais é possível estabelecer uma relação consanguínea entre os cônjuges, este número, contudo, não deve ser considerado em relação ao total de 333 da genealogia (corresponderia a 48\%). Além dos 14 casamentos (4\%) com nãoDeni (2 Apurinã, 2 Paumari, 2 Kulina e 8 não indígenas), há muitos casamentos que não possuem um vínculo genealógico, pois se situam no limite da memória. Toda genealogia parte dos ancestrais mais remotos e que, obviamente, não possuem ancestrais conhecidos que permitiriam o estabelecimento da relação consanguínea entre eles e seus cônjuges.

Em nossos dados há 262 uniões nas quais os dois pais dos cônjuges são conhecidos e 146 em que os quatro avós o são, mas nenhum dos dois casos corresponde ao total de casamentos $\mathrm{A} 1 \mathrm{C} 1$. Os casamentos consanguíneos da genealogia não estão contidos em nenhum destes dois universos, logo, não podemos relacionar os dois conjuntos de forma exclusiva. Considerando as relações entre os conjuntos de casamentos em que sabemos os dois pais dos cônjuges $(\mathrm{S} 2 \mathrm{P}=262)$, os quatro avós $(\mathrm{S} 4 \mathrm{~A}=146)$ e o vinculo genealógico entre os cônjuges $(\mathrm{A} 1 \mathrm{C} 1=159)$ temos:

$\mathrm{S} 4 \mathrm{~A} \subset \mathrm{S} 2 \mathrm{P}$

$$
\begin{gathered}
\mathrm{S} 4 \mathrm{~A} \cap \mathrm{SP} 2=146 \\
\mathrm{~S} 4 \mathrm{~A} \cap \mathrm{A} 1 \mathrm{C} 1=122 \\
\mathrm{~S} 2 \mathrm{~A} \cap \mathrm{A} 1 \mathrm{C} 1=158 \\
\mathrm{~S} 2 \mathrm{P}-\mathrm{S} 4 \mathrm{~A}=152 \\
\mathrm{~A} 1 \mathrm{C} 1-\mathrm{S} 4 \mathrm{~A}=37 \\
(\mathrm{~A} 1 \mathrm{C} 1-\mathrm{S} 4 \mathrm{~A}) \cap \mathrm{S} 2 \mathrm{P}=36 \\
\mathrm{~A} 1 \mathrm{C} 1-\mathrm{S} 2 \mathrm{P}=1
\end{gathered}
$$

\footnotetext{
${ }^{350}$ Todo casamento Deni envolve um homem e uma mulher, mesmo os casos de poligamia são pensados como dois casamentos e não um casamento coletivo. Idealmente, o homem deveria construir compartimentos ou mesmo residências separadas para cada uma das esposas e respectivos filhos, ou seja, cada família deveria ser separada da outra. Na prática, não há muitos casos em que duas esposas de um homem morem em casas diferentes, possivelmente, porque, em sua maioria, são irmãs, ou porque há uma enorme diferença temporal entre os casamentos.
} 
Estas relações podem ser representadas pelo seguinte gráfico, no qual o número entre colchetes indica o total de casamentos em cada conjunto e o simples indica o que está em cada campo:

Gráfico 4 - Tipos de casamentos da rede

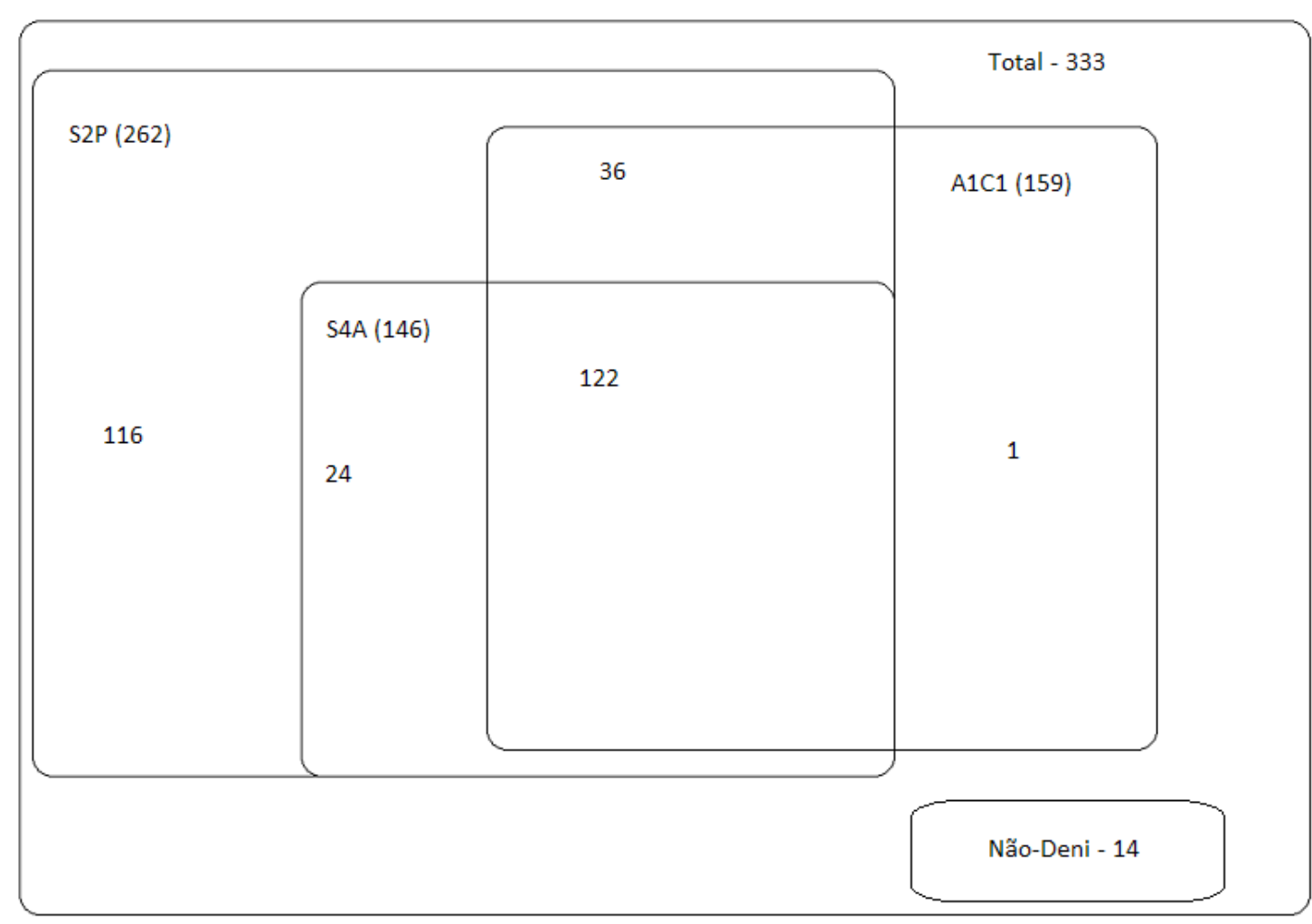

Do total de 262 casamentos em que são conhecidos os dois pais dos cônjuges é possível estabelecer um vínculo genealógico entre marido e esposa em 158 deles, ou seja, em aproximadamente $60 \%$. Se o vínculo parental fosse o único conhecido para ambos os cônjuges, o compartilhamento de um ancestral implicaria uma relação entre irmãos genealógicos, existindo uma relação entre marido e esposa que implicariam relações sexais que nem mesmo são concebidas pelo pensamento Deni. Os 36 casos (23\% dos $\mathrm{A} 1 \mathrm{C} 1)$ em os pais são conhecidos, mas não todos os avós, e existe uma relação genealógica entre os cônjuges, reforça a idéia de que há uma forte tendência a realização de casamentos consanguíneos.

Há uma forte correlação entre a memória genealógica e os vínculos consanguíneos entre os cônjuges, pois vemos que a proporção de casamentos consanguíneos aumenta consideravelmente quando há mais informações sobre os 
ancestrais. Quando todos os quatro ${ }^{351}$ avós de cada um dos cônjuges são conhecidos, o que ocorre em 146 uniões, 122 são $\mathrm{A} 1 \mathrm{C} 1$, ou seja, 84\% dos casamentos em que há informações sobre todos os vínculos até pelo menos $\mathrm{G}+2$ são consanguíneos. Se considerarmos apenas aqueles em que são conhecidos todos os bisavos (23), isto é, todos os parentes lineares de $\mathrm{G}+4$, a proporção chega a $100 \%$.

Embora não faça essa distinção entre casamentos consanguineos em que se conhece os pais, avós, ou bisavós, Maizza (2012: 133-144) demonstra que os Jarawara tendem a apresentar uma menor proporção de casamentos $\mathrm{A} 1 \mathrm{C} 1$. De um total de 53 casamentos da rede Jarawara, apenas para 14 (26\%) existe a memória dos vínculos genealógicos entre os cônjuges. Isto não quer dizer que há, entre os Jarawara, uma maior dispersão e exogamia em relação aos contexto Deni, mas, apenas, que o esquecimento cria uma situação em que as uniões ocorrem entre pessoas não relacionadas, pois, como mostra a autora, quase todos os casamentos da rede $(90 \%)$ estão envolvidos em anéis relativamente simples, do tipo $\mathrm{A} 2 \mathrm{C} 2^{352}$.

A rede Deni apresenta um total de 914 anéis do tipo A1C1, ou seja, a partir dos 159 casamentos consanguíneos é possível traçar 914 percursos entre os cônjuges. Como apresentamos acima, entre estas uniões, há muitas em que não se conhecem todos os avós dos cônjuges, ou seja, os vínculos entre eles foram traçados a partir de fragmentos de memória e, embora os esquecimentos possam ser significativos, iremos restringir nossas considerações às 122 uniões em que os parentes lineares de G+2 são conhecidos. Dado que o modelo ideal de aliança Deni afirma que as uniões devem ocorrer entre pessoas de determinada categoria terminológica (uvini), que tem seu limite mínimo de determinação genealógica na posição de primos cruzados, vamos considerar, apenas, os eventos em que marido e esposa poderiam, dada as informações existentes, manter tal relação entre si.

\footnotetext{
${ }^{351}$ Falamos quatro avós, mas isto é algo impreciso, pois devido a grande incidência de casamento de primos de primeiro grau, há muitos casos em que os avós dos cônjuges são os mesmos.

${ }_{352}$ A MaqPar é capaz de decompor as redes genealógicas em 5 tipos de anéis: $\mathrm{A} 1 \mathrm{C} 1, \mathrm{~A} 2 \mathrm{C} 1, \mathrm{~A} 2 \mathrm{C} 2$, $\mathrm{A} 3 \mathrm{C} 2, \mathrm{~A} 3 \mathrm{C} 3$. Eles correspondem a certo numero de sequências consanguíneas (C) e de casamentos (A), os anéis $\mathrm{A} 2 \mathrm{C} 2$ apresentam dois casamentos sendo que, invés de um ancestral comum entre os cônjuges de um mesmo casamento, há um ancestral conectando pares de cônjuges de diferentes casamentos. As relações entre as patrilinhas que apresentamos na seção anterior correspondem a casamentos do tipo A2C2, pois cada par de casamentos entre duas patrilinhas implicam que há uma relação consanguínea entre os cônjuges de diferentes casamentos. Para entender melhor esses anéis veja Dal Poz \& Silva (2010), Silva (2012), Maizza (2012).
} 
Há 798 anéis A1C1 na rede Deni que envolvem estes $122^{353}$ casamentos, sendo que há casos em que a união participa de apenas 1 anel e outro de 26, sendo a média 6,5 e a moda 4 aneis. É possível estabelecer, para a maior parte dos casamentos, mais de um percurso entre os cônjuges, ou seja, há mais de uma maneira de serem traçados os vínculos genealógicos que unem marido e mulher. Se tormamos o cruzamento de tipo dravidiano codificado na terminologia de parentesco como um parâmetro relevante, vemos que há grande variação na classificação dos cônjuges, muitos são os casos ambiguos, em que eles pode manter ser paralelos (ou não-casáveis) ou cruzados dependendo do percurso adotado

A tabela abaixo apresenta a quantidade de anéis gerada por cada um dos 122 casamento com avós conhecidos. Ela apresenta a quantidade de percursos que seriam cruzados e paralelos, na contagem dravidiana, e a ambiguidade do casal em relação ao cruzamento da relação. Lembramos que, cada anel é único, no sentido de que cada um representa a passagem por uma série diferente de individuos entre Ego masculino (marido) e Alter feminino (esposa), por isto é possível esta variação quanto ao paralelismo ou cruzamento entre os cônjuges. Muitos anéis são semelhantes, pois partem de um casal de ancestrais, assim, um dos caminhos passa pela esposa e o outro pelo marido.

A tabela a seguir esta dividida em três partes: a primeira (1. Numero de Anéis por Casamento) apresenta o número de cada casamento (Cas) e a quantidade de anéis (Tot Anel) em que se envolve; a segunda (2. Cruzamento por Casamento) realiza o agrupamento dos anéis pelo tipo de cruzamento (Cruz) paralelo $(\mathrm{P})$ ou cruzado $(\mathrm{X})$ no cálculo dravidiano e a quantidade de percursos que cada tipo (Num); por fim, a terceira parte (3. Ambiguidade) informa a ambiguidade no cruzamento. Esta última é uma relação entre a quantidade de percursos cruzados dividida pelo total, sendo expressa como uma porcentagem que varia entre 0 e $100 \%$, sendo que 0 indica que o casal é considerado paralelo em todos os percursos e $100 \%$ que só existem percursos cruzado, ou seja, quanto maior a porcentagem, mais caminhos cruzados existem entre marido e esposa.

\footnotetext{
${ }^{353}$ Um dos casamentos excluídos da análise corresponde a um dos quatro casos de endogamia de identidade patrilinear. Iremos analisar 122 de 159 casamentos (77\%) e como resultado iremos considerar apenas 3 dos 4 casos (75\%) de endogamia de patrilinha.
} 
Tabela 7 - Casamentos e tipos de cruzamento.

1. Numero de Anéis

por casamento

\begin{tabular}{|l|l|}
\hline Cas & Tot Anel \\
\hline
\end{tabular}

\begin{tabular}{|l|l|}
\hline 1 & 15 \\
\hline 2 & 15
\end{tabular}

34

$4 \quad 6$

$5 \quad 15$

$6 \quad 26$

$7 \quad 24$

93

$10 \quad 2$

$11 \quad 12$

$12 \quad 26$

$13 \quad 9$

$15 \quad 25$

$16 \quad 6$

$17 \quad 18$

$18 \quad 8$

$19 \quad 6$

$20 \quad 7$

$21 \quad 5$

$22 \quad 4$

$23 \quad 4$

$24 \quad 5$

$25 \quad 1$

$26 \quad 16$

$27 \quad 24$

$28 \quad 2$

$30 \quad 14$

\begin{tabular}{l|l}
31 & 4
\end{tabular}

$33 \quad 7$

\begin{tabular}{l|l}
34 & 4 \\
\hline
\end{tabular}

\begin{tabular}{l|l}
37 & 10
\end{tabular}

\begin{tabular}{l|l}
38 & 7
\end{tabular}

\begin{tabular}{l}
$40 \quad 8$ \\
\hline
\end{tabular}

\begin{tabular}{l|l}
42 & 7 \\
\hline
\end{tabular}

$43 \quad 7$

$44 \quad 16$

$45 \quad 5$

\begin{tabular}{|l|l|}
46 & 7 \\
\hline
\end{tabular}

\begin{tabular}{ll|l}
47 & 2 \\
\hline
\end{tabular}

\begin{tabular}{l|l}
49 & 24
\end{tabular}
2. Cruzamento

por casamento

\begin{tabular}{|c|c|c|}
\hline Cas & Cruz & Num \\
\hline 1 & $\mathrm{P}$ & 4 \\
\hline 2 & $\mathrm{P}$ & 10 \\
\hline 3 & $\mathrm{P}$ & 4 \\
\hline 4 & $\mathrm{P}$ & 2 \\
\hline 5 & $\mathrm{P}$ & 9 \\
\hline 6 & $\mathrm{P}$ & 14 \\
\hline 7 & $\mathrm{P}$ & 11 \\
\hline
\end{tabular}

\begin{tabular}{|c|c|c|}
\hline Cas & Cruz & Num \\
\hline 1 & $\mathrm{X}$ & 11 \\
\hline 2 & $\mathrm{X}$ & 5 \\
\hline
\end{tabular}

\begin{tabular}{|c|c|c|}
\hline 11 & $\mathrm{P}$ & 4 \\
\hline 12 & $\mathrm{P}$ & 14 \\
\hline 13 & $\mathrm{P}$ & 1 \\
\hline 15 & $\mathrm{P}$ & 14 \\
\hline 16 & $\mathrm{P}$ & 1 \\
\hline 17 & $\mathrm{P}$ & 16 \\
\hline 18 & $\mathrm{P}$ & 4 \\
\hline 19 & $\mathrm{P}$ & 2 \\
\hline 20 & $\mathrm{P}$ & 4 \\
\hline 21 & $\mathrm{P}$ & 1 \\
\hline 22 & $\mathrm{P}$ & 3 \\
\hline
\end{tabular}

\begin{tabular}{|l|l|l|}
24 & $P$ & 3 \\
\hline
\end{tabular}

\begin{tabular}{|c|c|c|}
\hline 26 & $\mathrm{P}$ & 4 \\
\hline 27 & $\mathrm{P}$ & 11 \\
\hline
\end{tabular}

\begin{tabular}{|c|c|c|}
\hline 30 & $\mathrm{P}$ & 12 \\
\hline 31 & $\mathrm{P}$ & 2 \\
\hline 33 & $\mathrm{P}$ & 2 \\
\hline 34 & $\mathrm{P}$ & 2 \\
\hline 37 & $\mathrm{P}$ & 6 \\
\hline 38 & $\mathrm{P}$ & 4 \\
\hline
\end{tabular}

\begin{tabular}{|l|l|l|}
\hline 42 & $\mathrm{P}$ & 3 \\
\hline 43 & $\mathrm{P}$ & 4 \\
\hline 44 & $\mathrm{P}$ & 8 \\
\hline
\end{tabular}

\begin{tabular}{|l|l|l|}
\hline 46 & $\mathrm{P}$ & 1
\end{tabular}

\begin{tabular}{|l|l|l|}
\hline 49 & $\mathrm{P}$ & 11 \\
\hline
\end{tabular}
3. Ambiguidade

\begin{tabular}{|c|}
\hline Amb X/Tot \\
\hline $73 \%$ \\
\hline $33 \%$ \\
\hline $0 \%$ \\
\hline $67 \%$ \\
\hline $40 \%$ \\
\hline $46 \%$ \\
\hline $54 \%$ \\
\hline $100 \%$ \\
\hline $100 \%$ \\
\hline $67 \%$ \\
\hline $46 \%$ \\
\hline $89 \%$ \\
\hline $44 \%$ \\
\hline $83 \%$ \\
\hline $11 \%$ \\
\hline $50 \%$ \\
\hline $67 \%$ \\
\hline $43 \%$ \\
\hline $80 \%$ \\
\hline $25 \%$ \\
\hline $100 \%$ \\
\hline $40 \%$ \\
\hline $100 \%$ \\
\hline $75 \%$ \\
\hline $54 \%$ \\
\hline $100 \%$ \\
\hline $14 \%$ \\
\hline $50 \%$ \\
\hline $71 \%$ \\
\hline $50 \%$ \\
\hline $40 \%$ \\
\hline $43 \%$ \\
\hline $100 \%$ \\
\hline $57 \%$ \\
\hline $43 \%$ \\
\hline $50 \%$ \\
\hline $100 \%$ \\
\hline $86 \%$ \\
\hline $100 \%$ \\
\hline $54 \%$ \\
\hline \\
\hline
\end{tabular}




\begin{tabular}{|c|c|}
\hline 50 & 5 \\
\hline 51 & 8 \\
\hline 52 & 6 \\
\hline 53 & 10 \\
\hline 54 & 10 \\
\hline 55 & 2 \\
\hline 56 & 2 \\
\hline 57 & 3 \\
\hline 58 & 7 \\
\hline 59 & 7 \\
\hline 60 & 4 \\
\hline 62 & 4 \\
\hline 64 & 7 \\
\hline 66 & 10 \\
\hline 67 & 7 \\
\hline 68 & 3 \\
\hline 69 & 2 \\
\hline 70 & 5 \\
\hline 71 & 4 \\
\hline 72 & 4 \\
\hline 73 & 4 \\
\hline 74 & 2 \\
\hline 75 & 4 \\
\hline 77 & 4 \\
\hline 79 & 2 \\
\hline 80 & 5 \\
\hline 81 & 4 \\
\hline 82 & 10 \\
\hline 83 & 4 \\
\hline 85 & 8 \\
\hline 86 & 2 \\
\hline 88 & 7 \\
\hline 90 & 4 \\
\hline 91 & 6 \\
\hline 92 & 2 \\
\hline 94 & 7 \\
\hline 96 & 5 \\
\hline 97 & 5 \\
\hline 98 & 2 \\
\hline 99 & 6 \\
\hline 100 & 7 \\
\hline 102 & 2 \\
\hline 103 & 3 \\
\hline 104 & 14 \\
\hline 105 & 3 \\
\hline
\end{tabular}

\begin{tabular}{|c|c|c|c|c|c|}
\hline & 50 & $x$ & \multirow[t]{2}{*}{5} \\
\hline 51 & $P$ & 8 & & & \\
\hline 52 & $P$ & 6 & & & \\
\hline 53 & $\mathrm{P}$ & 6 & 53 & $x$ & 4 \\
\hline 54 & $P$ & 6 & 54 & $x$ & 4 \\
\hline 55 & $\mathrm{P}$ & 2 & & & \\
\hline & & & 56 & $x$ & 2 \\
\hline 57 & $P$ & 2 & 57 & $x$ & 1 \\
\hline 58 & $\mathrm{P}$ & 3 & 58 & $x$ & 4 \\
\hline 59 & $\mathrm{P}$ & 4 & 59 & $x$ & 3 \\
\hline 60 & $\mathrm{P}$ & 2 & 60 & $x$ & 2 \\
\hline & & & 62 & $x$ & 4 \\
\hline 64 & $P$ & 4 & 64 & $x$ & 3 \\
\hline 66 & $P$ & 4 & 66 & $x$ & 6 \\
\hline 67 & $P$ & 2 & 67 & $x$ & 5 \\
\hline 68 & $P$ & 3 & & & \\
\hline 69 & $P$ & 2 & & & \\
\hline & & & 70 & $x$ & 5 \\
\hline 71 & $P$ & 2 & 71 & $x$ & 2 \\
\hline 72 & $P$ & 2 & 72 & $x$ & 2 \\
\hline & & & 73 & $x$ & 4 \\
\hline 74 & $P$ & 2 & & & \\
\hline & & & 75 & $x$ & 4 \\
\hline & & & 77 & $x$ & 4 \\
\hline & & & 79 & $x$ & 2 \\
\hline 80 & $P$ & 5 & & & \\
\hline & & & 81 & $x$ & 4 \\
\hline 82 & $P$ & 4 & 82 & $x$ & 6 \\
\hline 83 & $\mathrm{P}$ & 4 & & & \\
\hline 85 & $P$ & 3 & 85 & $x$ & 5 \\
\hline 86 & $P$ & 1 & 86 & $x$ & 1 \\
\hline 88 & $P$ & 1 & 88 & $x$ & 6 \\
\hline 90 & $P$ & 4 & & & \\
\hline 91 & $\mathrm{P}$ & 2 & 91 & $X$ & 4 \\
\hline & & & 92 & $X$ & 2 \\
\hline & & & 94 & $x$ & 7 \\
\hline 96 & $P$ & 1 & 96 & $x$ & 4 \\
\hline & & & 97 & $X$ & 5 \\
\hline 98 & $P$ & 1 & 98 & $x$ & 1 \\
\hline 99 & $P$ & 3 & 99 & $x$ & 3 \\
\hline 100 & $\mathrm{P}$ & 2 & 100 & $X$ & 5 \\
\hline 102 & $\mathrm{P}$ & 2 & & & \\
\hline & & & 103 & $X$ & 3 \\
\hline 104 & $P$ & 4 & 104 & $X$ & 10 \\
\hline 105 & $P$ & 2 & 105 & $x$ & 1 \\
\hline
\end{tabular}

\begin{tabular}{|c|}
\hline $100 \%$ \\
\hline $0 \%$ \\
\hline $0 \%$ \\
\hline $40 \%$ \\
\hline $40 \%$ \\
\hline $0 \%$ \\
\hline $100 \%$ \\
\hline $33 \%$ \\
\hline $57 \%$ \\
\hline $43 \%$ \\
\hline $50 \%$ \\
\hline $100 \%$ \\
\hline $43 \%$ \\
\hline $60 \%$ \\
\hline $71 \%$ \\
\hline $0 \%$ \\
\hline $0 \%$ \\
\hline $100 \%$ \\
\hline $50 \%$ \\
\hline $50 \%$ \\
\hline $100 \%$ \\
\hline $0 \%$ \\
\hline $100 \%$ \\
\hline $100 \%$ \\
\hline $100 \%$ \\
\hline $0 \%$ \\
\hline $100 \%$ \\
\hline $60 \%$ \\
\hline $0 \%$ \\
\hline $63 \%$ \\
\hline $50 \%$ \\
\hline $86 \%$ \\
\hline $0 \%$ \\
\hline $67 \%$ \\
\hline $100 \%$ \\
\hline $100 \%$ \\
\hline $80 \%$ \\
\hline $100 \%$ \\
\hline $50 \%$ \\
\hline $50 \%$ \\
\hline $71 \%$ \\
\hline $0 \%$ \\
\hline $100 \%$ \\
\hline $71 \%$ \\
\hline \\
\hline \\
\hline
\end{tabular}




\begin{tabular}{|c|c|}
\hline 106 & 1 \\
\hline 108 & 4 \\
\hline 110 & 2 \\
\hline 114 & 8 \\
\hline 122 & 5 \\
\hline 123 & 1 \\
\hline 124 & 10 \\
\hline 126 & 6 \\
\hline 132 & 4 \\
\hline 133 & 9 \\
\hline 136 & 6 \\
\hline 137 & 4 \\
\hline 140 & 3 \\
\hline 141 & 7 \\
\hline 143 & 1 \\
\hline 144 & 5 \\
\hline 145 & 8 \\
\hline 148 & 7 \\
\hline 149 & 6 \\
\hline 151 & 8 \\
\hline 152 & 2 \\
\hline 158 & 3 \\
\hline 159 & 1 \\
\hline 160 & 4 \\
\hline 172 & 4 \\
\hline 177 & 4 \\
\hline 186 & 2 \\
\hline 188 & 2 \\
\hline 192 & 2 \\
\hline 196 & 4 \\
\hline 216 & 2 \\
\hline 219 & 9 \\
\hline 241 & 2 \\
\hline 264 & 2 \\
\hline 275 & 2 \\
\hline 289 & 2 \\
\hline & \\
\hline
\end{tabular}

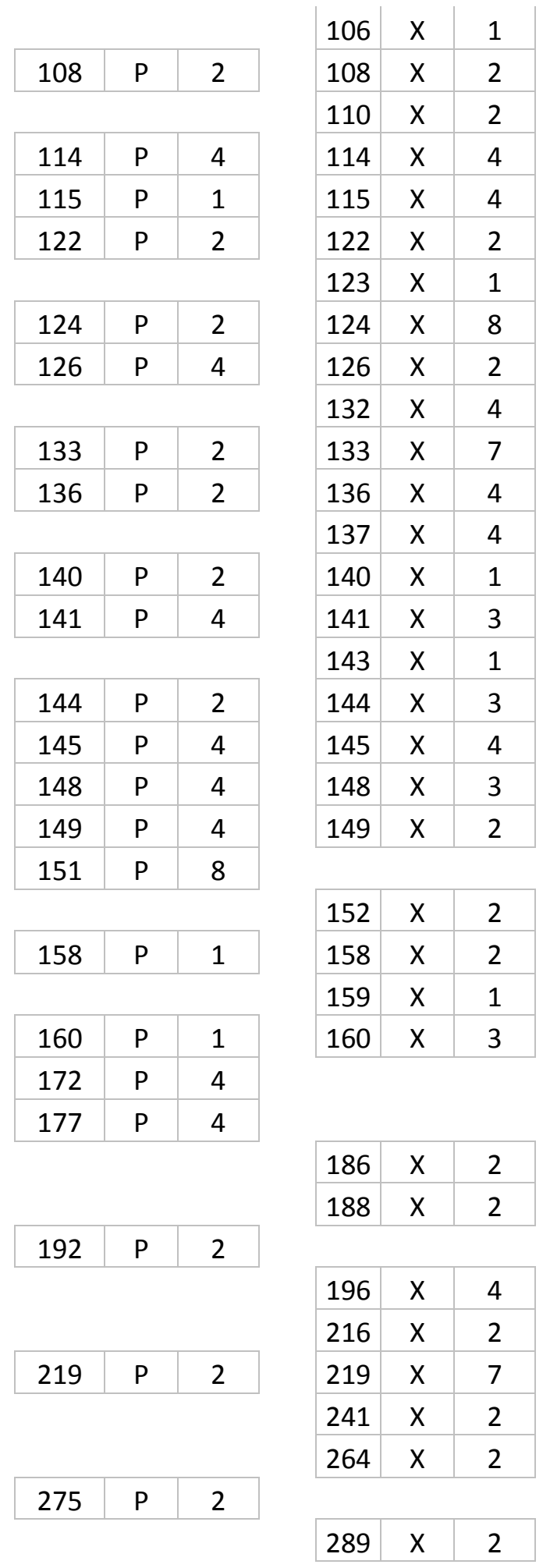

\begin{tabular}{|c|}
\hline $100 \%$ \\
\hline $50 \%$ \\
\hline $100 \%$ \\
\hline $50 \%$ \\
\hline $80 \%$ \\
\hline $50 \%$ \\
\hline $100 \%$ \\
\hline $80 \%$ \\
\hline $13 \%$ \\
\hline $78 \%$ \\
\hline $67 \%$ \\
\hline $100 \%$ \\
\hline $33 \%$ \\
\hline $13 \%$ \\
\hline $60 \%$ \\
\hline $50 \%$ \\
\hline $43 \%$ \\
\hline $33 \%$ \\
\hline $0 \%$ \\
\hline $100 \%$ \\
\hline $67 \%$ \\
\hline $100 \%$ \\
\hline $75 \%$ \\
\hline $0 \%$ \\
\hline $0 \%$ \\
\hline $100 \%$ \\
\hline $100 \%$ \\
\hline $0 \%$ \\
\hline $100 \%$ \\
\hline $100 \%$ \\
\hline $78 \%$ \\
\hline $100 \%$ \\
\hline $100 \%$ \\
\hline $0 \%$ \\
\hline $100 \%$ \\
\hline \\
\hline
\end{tabular}

Existe grande variação nos anéis e eles não parecem seguir um padrão claramente definido. Existem 353 percursos paralelos (44\%) e 445 cruzados (56\%), sendo que $106(86 \%)$ casamentos apresentam anéis cruzados e $86(70 \%)$ paralelos. Há 52 casos casos sem ambiguidade, sendo 36 (30\%) do tipo cruzado e 16 (13\%) do paralelo. Podemos perceber que, mesmo havendo certa tendência a maior ocorrência de 
ligações cruzadas, segundo o cálculo dravidiano, a variação é pequena, aparecendo de forma acentuada apenas nos casos não ambiguos, quando a proporação é pouco superior a $2: 1$.

Focando unicamente no cruzamento, temos muita ambiguidade nos resultados, devemos, então, levar em conta também outros parâmetros dos percursos: o comprimento e a Ordem. O comprimento de um cadeia corresponde ao número de conexões que ela contém, ou seja, no caso dos $\mathrm{A} 1 \mathrm{C} 1$, corresponde a quantidade de relações de paternidade/filiação que ligam os cônjuges. Os 798 anéis da rede Deni se distribuem nos seguintes comprimentos:

Tabela 8 - Comprimentos dos anéis

\begin{tabular}{|c|c|c|}
\hline Comprimento & Quantidade & $\%$ \\
\hline 4 & 82 & $10 \%$ \\
\hline 5 & 51 & $6 \%$ \\
\hline 6 & 154 & $\underline{\mathbf{1 9 \%}}$ \\
\hline 7 & 136 & $\underline{\mathbf{1 7 \%}}$ \\
\hline 8 & 158 & $\underline{\mathbf{2 0 \%}}$ \\
\hline 9 & 176 & $\underline{\mathbf{2 2 \%}}$ \\
\hline 10 & 41 & $5 \%$ \\
\hline Total & 798 & \\
\hline
\end{tabular}

A Ordem é um dado sobre os anéis que é gerado pela MaqPar e permite entender melhor a distribuição dos cônjuges conforme os comprimentos dos percursos. Ela tem como base a geração relativa e a lateralidade, indicando em que posição Alter se situa independente do sexo dos parentes de ligação. Seu significado pode ser apreendido na figura abaixo adaptada de Silva (2012: 49). 
Figura 15 - Classificação das sequências consanguíneas.

Ordens de sequências consanguíneas e número de conexões genealógicas primárias (Comprimento):

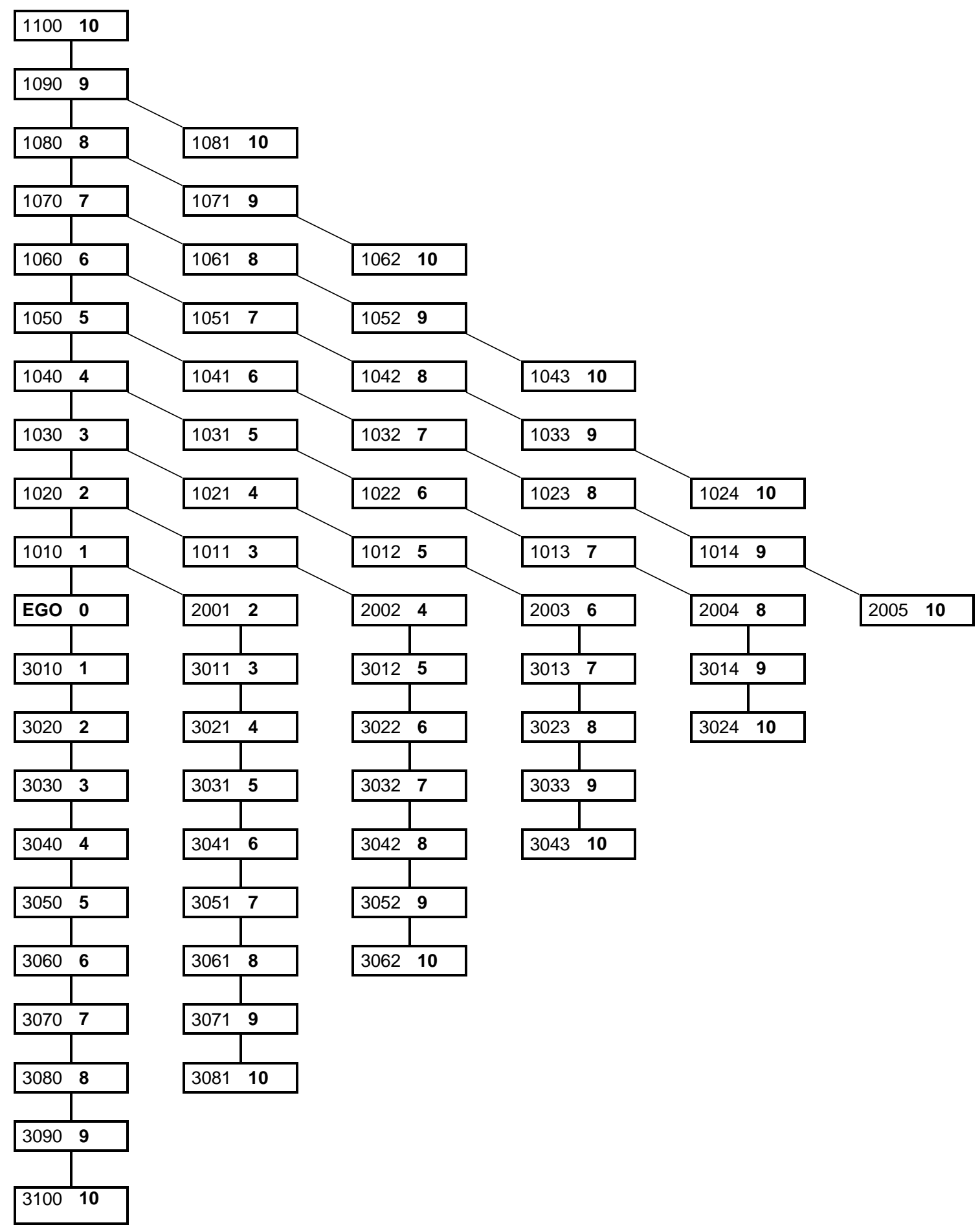


“As linhas da Figura [acima] partem de 'EGO 0' em direção a seus parentes (ALTER). Linhas verticais ou oblíquas significam exatamente a mesma coisa: relações de filiação, $\mathrm{F}$ e $\mathrm{M}$ quando sobem, $\mathrm{S}$ e $\mathrm{D}$ quando descem. $\mathrm{O}$ alinhamento horizontal corresponde a posições de parentesco de mesma geração. [...] Cada posição de parentesco é apresentada assim como no exemplo 10226 , contendo um número de quatro dígitos, seguido de um número isolado, com as seguintes informações: o primeiro algarismo indica se o parente, em relação a Ego, é ascendente (1), da mesma geração (2) ou descendente (3). O segundo e o terceiro indicam a distância geracional do parente (de 00 a 10) e o quarto, a distância lateral (grau de colateralidade). Finalmente, o número isolado indica o grau civil do parente, isto é, o número de conexões que existem entre ego e alter." (Silva 2012: 50)

Devido à discrepância na distribuição entre os $\mathrm{A} 1 \mathrm{C} 1$ totais da rede e aqueles em que se conhecem os quatro avós dos cônjuges, vamos apresentar ambos. As ordens encontradas nos anéis $\mathrm{A} 1 \mathrm{C} 1$ da rede genealógica Deni são, levando-se em conta a quantidade de repetições (Rep), as seguintes:

Tabela 9 - Frequência de repetição das ordens

\begin{tabular}{|c|c|c|}
\multicolumn{4}{|c|}{ A1C1 $\cap$ S4A } \\
\hline Ordem & Rep & $\%$ \\
\hline 1012 & 15 & $2 \%$ \\
\hline 1013 & 51 & $6 \%$ \\
\hline 1014 & 92 & $\mathbf{1 2 \%}$ \\
\hline 1022 & 3 & $0 \%$ \\
\hline 1023 & 11 & $1 \%$ \\
\hline 1024 & 4 & $1 \%$ \\
\hline 2002 & 81 & $\mathbf{1 0 \%}$ \\
\hline 2003 & 143 & $\mathbf{1 8 \%}$ \\
\hline 2004 & 130 & $\mathbf{1 6 \%}$ \\
\hline 2005 & 32 & $4 \%$ \\
\hline 3012 & 36 & $5 \%$ \\
\hline 3013 & 85 & $\mathbf{1 1 \%}$ \\
\hline 3014 & 83 & $\mathbf{1 0 \%}$ \\
\hline 3021 & 1 & $0 \%$ \\
\hline 3022 & 8 & $1 \%$ \\
\hline 3023 & 17 & $2 \%$ \\
\hline 3024 & 5 & $1 \%$ \\
\hline 3033 & 1 & $0 \%$ \\
\hline Total & 798 & $100 \%$ \\
\hline
\end{tabular}

\begin{tabular}{|c|c|c|}
\multicolumn{3}{|c|}{ A1C1 } \\
\hline Ordem & Rep & $\%$ \\
\hline 1012 & 27 & $3 \%$ \\
1013 & 63 & $7 \%$ \\
\hline 1014 & 92 & $\underline{\mathbf{1 0 \%}}$ \\
\hline 1022 & 3 & $0 \%$ \\
\hline 1023 & 11 & $1 \%$ \\
\hline 1024 & 4 & $0 \%$ \\
\hline 2002 & 103 & $\mathbf{1 1 \%}$ \\
\hline 2003 & 161 & $\mathbf{1 8 \%}$ \\
\hline 2004 & 136 & $\mathbf{1 5 \%}$ \\
\hline 2005 & 32 & $4 \%$ \\
\hline 3012 & 40 & $4 \%$ \\
\hline 3013 & 93 & $\mathbf{1 0 \%}$ \\
\hline 3014 & 83 & $9 \%$ \\
\hline 3021 & 4 & $0 \%$ \\
\hline 3022 & 12 & $1 \%$ \\
\hline 3023 & 30 & $2 \%$ \\
\hline 3024 & 5 & $1 \%$ \\
\hline 3033 & 2 & $0 \%$ \\
\hline Total & 906 & $99 \%$ \\
\hline
\end{tabular}

\begin{tabular}{|c|} 
Diferença \\
\hline 12 \\
\hline 12 \\
\hline 0 \\
\hline 0 \\
\hline 0 \\
\hline 0 \\
\hline$\underline{\mathbf{2 2}}$ \\
\hline$\underline{\mathbf{1 8}}$ \\
\hline 6 \\
\hline 0 \\
\hline 4 \\
\hline 7 \\
\hline 0 \\
\hline 2 \\
\hline 4 \\
\hline 13 \\
\hline 0 \\
\hline 1 \\
\hline
\end{tabular}


Os dados relativos aos casos exclusivamente A1C1 estão incompletos na tabela, pois, 8 deles situam Alter em ordens que não existem quando consideramos apenas os $\mathrm{A} 1 \mathrm{C} 1$ em que os quatro avós dos cônjuges são conhecidos (A1C1 $\cap \mathrm{S} 4 \mathrm{~A})$. Os 8 casos ausentes são: 2 do tipo 1011, 4 do 3011 e 2 do 3032. Eles correspondem a menos de 1\% da amostragem, portanto, seu desparecimento, quando consideramos apenas os anéis em que os 4 avós são conhecidos, não será levado em conta.

Nos casos em que a memória é mais fragmentária, isto é, os 37 casamentos nos quais existe a memória de um vínculo genealógico entre os cônjuges, mas nem todos os ancestrais de G+2 são conhecidos, há muitos casamentos de primos de primeiro (2002) e segundo grau (2003). Isto mostra que a memória preserva algumas relações de filiação que tornam os cônjuges parentes genealogicamente próximos, segundo percursos limitados, mas esquece outros e, como mostramos, são os laços de filiação paterna esquecidos de maneira mais sistemática. Vemos, inclusive, que os casamentos de primos de primeiro grau correspondem ao $3^{\circ}$. tipo mais comum quando consideramos a amostra total, tornando-se o $6^{\circ}$. na restrita, ou seja, são esquecimentos importantes.

A tabela mostra que, os casamentos entre pessoas de mesma geração são mais frequentes do que aqueles que envolvem cônjuges de geração acima ou abaixo de Ego. $\mathrm{Na}$ amostra reduzida, são $386(48 \%)$ percursos que situam os cônjuges na mesma geração, sendo que 236 (30\%) situam a esposa em gerações descendentes e 176 (22\%) em ascendentes. Na amostra total (914 anés) são, respectivamente, 432 (47\%), 280 (31\%) e 202 (22\%), ou seja, não há uma diferença na proporção e sim um aumento no número de casamentos entre parentes genealogicamente próximos, mas que estão sujeitos a certos esquecimentos seletivos.

Se lembrarmos que, como apontamos no capítulo anterior, há identidade entre as gerações alternadas no modelo terminológico, temos as ordens 1022, 1023, 1024, 3021, 3022, 2023 e 3024 como pertencentes a mesma geração que Ego. O resultado dessas equivalências faz com que mais da metade dos percursos situem Ego e Alter no mesmo patamar, atingindo 501 de 914 percursos na amostra total ou 435 de 798 na reduzida, ou seja, aproximadamente 54\% dos casos. Há, assim, uma preferência pela realização de casamentos com pessoas de mesma geração, mas que não é muito acentuada.

Há, de qualquer forma, um campo bem definido em que ocorrem os casamentos Deni. Não há casamentos entre parentes lineares, nem entre pessoas afastadas por mais 
de 3 gerações, e este últimos são raros. $\mathrm{O}$ universo em que se situam as uniões consanguíneas pode ser visualizado na figura abaixo, onde os números representam o total de ocorrências de percursos da amostra restrita e os entre colchetes o da amostra total:

Figura 16 - Frequência das sequências consanguíneas

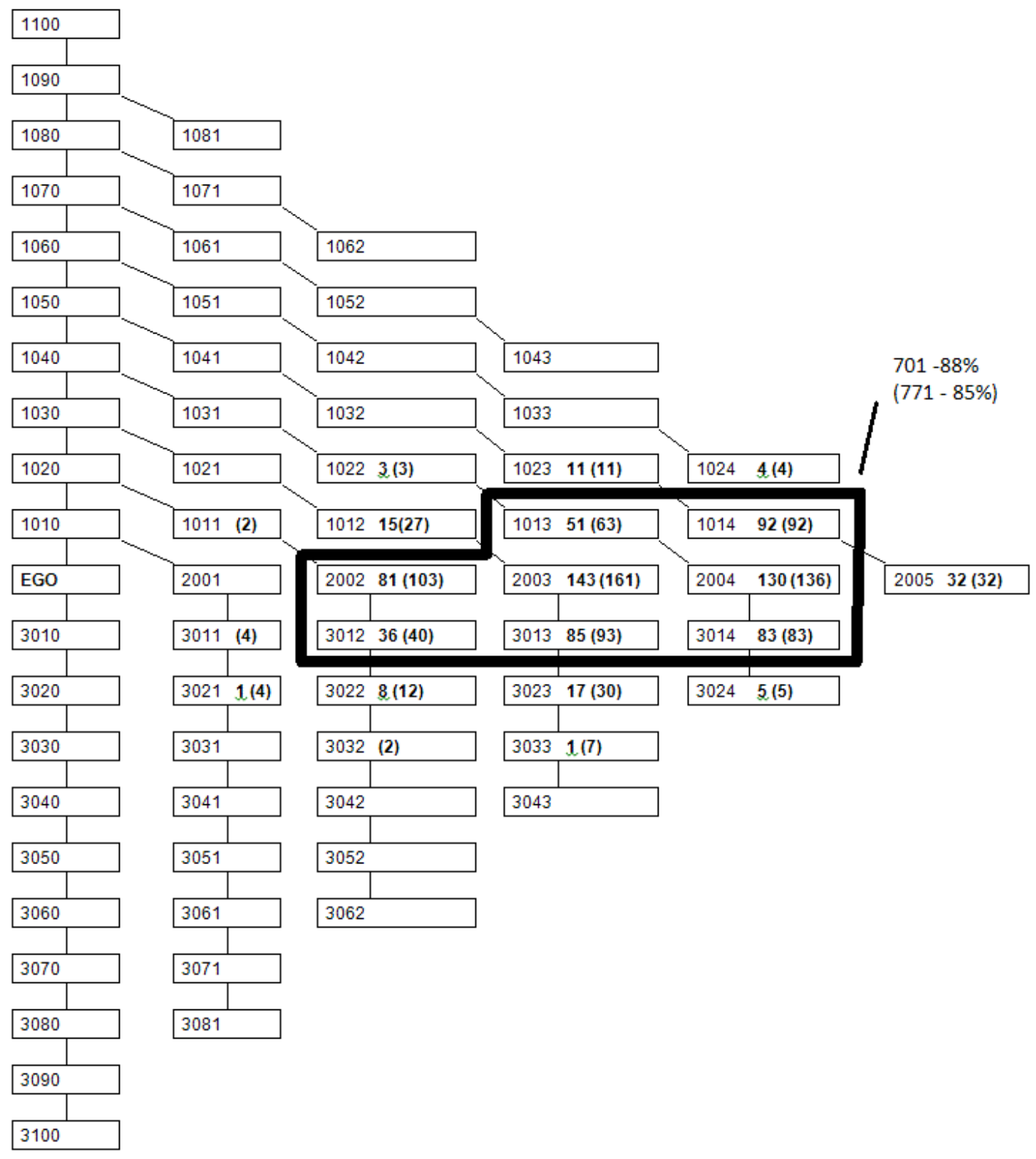

Temos, agora, condições de considerar melhor a questão dos cruzamentos, levando em conta a Ordem dos percursos e o total de conexões. Paralelismo e cruzamento não são os únicos parâmetros relevantes, pois, os próprios Deni definem a proibição do incesto como as relações sexuais com parentes que incluem os cruzados de 
gerações adjacentes. A relação entre cruzamento e Ordem pode ser verificada nas tabelas abaixo, que apresenta a Ordem, a quantidade de percursos (Num) para cada tipo de cruzamento e o estatuto paralelo (P) ou cruzado (X), segundo o cálculo dravidiano (Drav).

Tabela 10 - Ordem e cruzamento na geração de Ego e alternadas

\begin{tabular}{|c|c|c|c|c|c|c|c|}
\hline \multicolumn{4}{|c|}{ Ordem Num Drav } & \multicolumn{4}{|c|}{ Ordem Num Drav } \\
\hline 2002 & 3 & $\mathrm{P}$ & $4 \%$ & 1022 & 3 & $\mathrm{X}$ & $100 \%$ \\
\hline 2002 & 78 & $X$ & $96 \%$ & 1023 & 5 & $\mathrm{P}$ & $45 \%$ \\
\hline 2003 & 55 & $\mathrm{P}$ & $38 \%$ & 1023 & 6 & $X$ & $55 \%$ \\
\hline 2003 & 88 & $X$ & $62 \%$ & 1024 & 2 & $\mathrm{P}$ & $50 \%$ \\
\hline 2004 & 62 & $\mathrm{P}$ & $48 \%$ & 1024 & 2 & $X$ & $50 \%$ \\
\hline 2004 & 68 & $X$ & $52 \%$ & & & & \\
\hline 2005 & 26 & $\mathrm{P}$ & $81 \%$ & & & & \\
\hline 2005 & 6 & $X$ & $19 \%$ & & & & \\
\hline
\end{tabular}

\begin{tabular}{|cccc|}
\hline Ordem & Num & Drav & \\
\hline 3021 & 1 & X & $100 \%$ \\
\hline 3022 & 4 & P & $50 \%$ \\
3022 & 4 & X & $50 \%$ \\
\hline 3023 & 9 & P & $53 \%$ \\
3023 & 8 & X & $47 \%$ \\
\hline 3024 & 2 & P & $40 \%$ \\
3024 & 3 & X & $60 \%$ \\
\hline
\end{tabular}

Tabela 11 - Ordem e cruzamento na $\mathrm{G}+1, \mathrm{G}-1$ e $\mathrm{G}-3$

\begin{tabular}{|cccc|}
\hline Ordem & Num & Drav & \\
\hline 1012 & 3 & P & $20 \%$ \\
1012 & 12 & X & $80 \%$ \\
\hline 1013 & 31 & P & $61 \%$ \\
1013 & 20 & X & $39 \%$ \\
\hline 1014 & 42 & P & $46 \%$ \\
1014 & 50 & X & $54 \%$ \\
\hline
\end{tabular}

\begin{tabular}{|cccc|} 
Ordem & Num & Drav & \\
\hline 3012 & 24 & P & $67 \%$ \\
3012 & 12 & X & $33 \%$ \\
\hline 3013 & 51 & P & $60 \%$ \\
3013 & 34 & X & $40 \%$ \\
\hline 3014 & 33 & P & $40 \%$ \\
3014 & 50 & X & $60 \%$ \\
\hline 3033 & 1 & P & $100 \%$ \\
\hline
\end{tabular}

Podemos perceber que, na geração de Ego (e alternas), a importância do cruzamento é inversamente proporcional a distância genealógica: quanto menor a distância, maior é ocorrência de casamentos de primos cruzados. Os casamentos com primos de primeiro grau (2002) ocorrem, quase que exclusivamente, com primos cruzados, os 3 percursos paralelos existentes correspondem a 2 casamentos, um dos quais participa de dois anéis. Este casamento ocorreu entre Ego e sua FBD (que possui os percursos FMSD e FFSD) e, portanto, é um dos casos de endogamia de patrilinha identificados na seção anterior.

Ordenando o cruzamento dominante pelo tamanho da conexão temos: 


\begin{tabular}{|c|c|c|c|c|c|c|c|}
\hline & \multicolumn{7}{|c|}{ Tabela 12 - Tamanho da conexão ${ }^{354}$} \\
\hline Geração & 4 & 5 & 6 & 7 & 8 & 9 & 10 \\
\hline Ego & X 96\% & & X 62\% & & $\mathrm{X} 52 \%$ & & $\mathrm{P} 81 \%$ \\
\hline Ascendente & & X $80 \%$ & & $\mathrm{P} 61 \%$ & $\mathrm{X} 45 \%$ & $\mathrm{X} 54 \%$ & $50 \%$ \\
\hline Descendente & & P $67 \%$ & $50 \%$ & $\mathrm{P} 60 \%$ & P 53\% & & $\mathrm{X} 60 \%$ \\
\hline
\end{tabular}

Na geração de Ego, na qual se situam os primos, é possível perceber claramente a preferência pelos casamentos cruzados quando há poucas conexões, isto é, quando há maior proximidade entre os cônjuges. Este é um ponto interessante, pois, embora já tenha sido estabelecido que o dravidiano amazônico se diferencia do indiano pelo seu concentrismo (Viveiros de Castro 1993, 1996, 2002), no qual a distância possui um papel fundamental, até o presente momento, isto não havia sido demonstrado no plano empirico. Vemos que, ao contrário do que afirmam alguns, de que nas terras baixas da América do Sul há uma ausência de regras, a matemática matrimonial Deni segue seu modelo consciente de casamento, porém a distância entre os cônjuges torna outros parâmetros relevantes e não apenas o cruzamento. A partir de certo grau de afastamento, é possível que o sistema passe a ser mais dependente da história, talvez tendo maior peso a composição da comunidade política (Dreyfus 1993) sobre o regime de alianças.

Os Deni são um exemplo de como um regime perfeitamente dravidiano, com uma relativamente alta incidência de casamentos de primos cruzados de primeiro grau, funciona em uma grande população, cujas aldeias tendem a passar os 100 moradores. A flexibilização da aplicação da regra de cruzamento permite que se estabeleça um regime de aliança no qual parentes distantes tornam-se afins efetivos, ou seja, são novamente tornados próximos pela realização de uniões matrimoniais. Dada as peculiaridades da terminologia de parentesco Deni, seria necessário fazer a distorção terminológica da genealogia e, por conseguinte, dos resultados da aplicação dos cruzamentos, isto, contudo, nos escapa no momento, pois é impossível saber como se classificavam, ou tratavam, as pessoas de gerações já falecidas e que participam da maioria dos percursos.

Se atentarmos para a questão das patrilinhas, vemos que, um dos casos de endogamia situa-se na Ordem 2003, isto é, envolve cônjuges que seriam primos de segundo grau. A relevância da exogamia de patrilinhas parece ter algum peso quando observamos que, se tomarmos exclusivamente os laços de filiação materna, que

\footnotetext{
${ }^{354}$ Todo número par de conexões indica que a pessoa esta situada na mesma geração de Ego, segundo a terminologia de parentesco. Foram desconsiderados os resultados que só apresentavam um tipo de cruzamento e baixo numero de ocorrências. As células na cor cinza indicam menos que 10 casos totais.
} 
constituiriam matrilinhas, os casos de endogamia são desproporcionalmente mais comuns.Há, na geração de Ego, um único caso de casamento entre pessoas relacionadas exclusivamente por laços de filiação paterna, mas, como podemos ver na tabela abaixo, existem 12 casamentos em que o vínculo passa, exclusivamente, através de mulheres.

Tabela 13 - Endogamia de linhas patri/matri.

\begin{tabular}{|c|c|c|c|}
\hline Ordem & Drav & Relação & Num \\
\hline 2002 & P & MMDD & 1 \\
\hline 2003 & P & MMMDDD & 11 \\
\hline 2003 & P & FFFSSD & 1 \\
\hline
\end{tabular}

Devemos analisar as gerações ascentes levando em conta apenas as conexões de número impar, pois as pares equivaleriam a de Ego. Encontramos uma situação muito diferente, já que não é possível estabelecer uma correlação direta entre a distância e o paralelismo ou cruzamento, já que, embora os mais próximos (5 conexões) sejam em sua maioria cruzados $(80 \%)$, aqueles com 7 conexões tornam-se, em sua maioria, paralelos (61\%), mas voltam a predominar os cruzados com 9 (54\%). As regularidades e irregularidades devem ser consideradas em detalhe, pois não parece simplesmente ser a distância o parâmetro relevante, pois tratam-se de uniões condenadas segundo o modelo nativo da proibição do incesto, independe do cruzamento ser paralelo ou cruzado.

Devemos levar em conta os percursos envolvidos e a repetição de cada um, como mostrado abaixo:

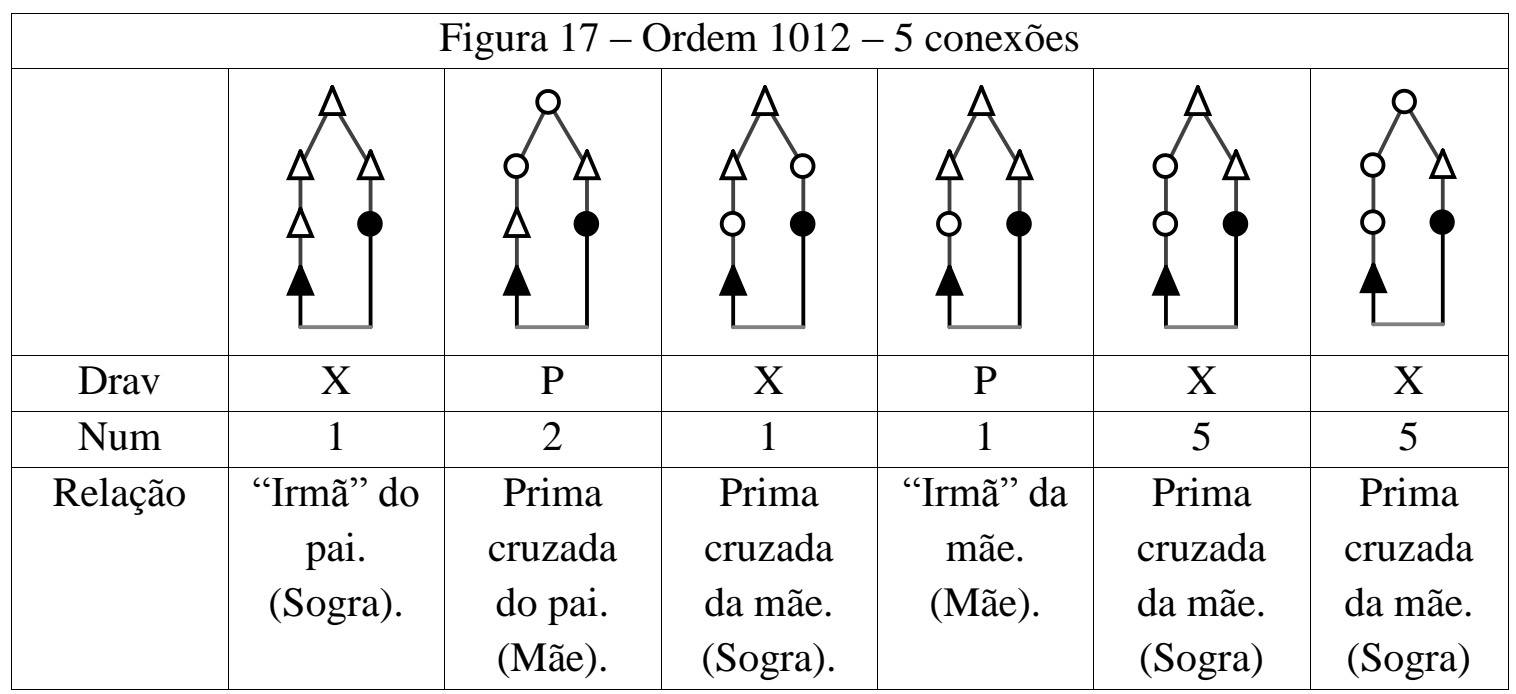


Levando em consideração os vínculos genealógicos entre os cônjuges, vemos que não existem casamentos nos quais Alter e Ego sejam moradores de uma mesma casa, o que ocorreria, dada a residência uxorilocal, no caso da ligação ocorrer através da avó materna de Ego e da mãe de Alter ${ }^{355}$. A co-residência é um indicativo de proximidade social, logo, a ausência destas uniões pode indicar que, além da proximidade/distancia genealógica, a proximidade social é, também, um fator relevante. Entre os casamentos desta Ordem está, inclusive, um dos casos de endogamia de patrilinha, cujos cônjuges poderiam ser pessoas socialmente afastadas, mas, por serem originários do Xeruã, não temos como analisar detalhadamente o caso.

Curiosamente, contudo, como mostramos acima, quando Ego e Alter estão na mesma geração, há 12 casos em que estes poderiam ser co-residentes. A ausência de casamentos deste tipo com mulheres na Ordem 1012 (5 conexões), mas a sua existência em relação as filhas dessas mulheres (6 conexões), parece reforçar ideia de que é necessário a existência de certa distancia social/genealógica mínima. Como veremos a seguir, na Ordem 1013 (7 conexões) existem percursos que passam exclusivamente por vínculos de filiação materna, formando casais que poderiam, no limite, habitar em uma mesma residência antes do casamento, mas, dada a inexistência de casas que abarcam 4 gerações de mulheres, isto corresponde a uma possibilidade que não se verifica na prática, ou seja, é uma extensão do modelo para além da sua aplicabilidade.

De qualquer forma, a maior parte dos casamentos de Ordem 1012 ocorre com a prima cruzada dos pais (13 de 15 casos), cujo estatuto de cruzado ou paralelo seria função da relação com os pais, isto é, primos cruzados de mesmo sexo que o pai seriam cruzados e os de sexo oposto seriam paralelos. Talvez seja impossível entender o que se passa aqui sem levar em conta a história, pois, observamos em campo que, os Deni têm por costume entregarem um ou mais filhos para que sejam criados pelos avós da criança, o que é muito frequente nos casos em que os pais se separam e casam novamente com outras pessoas. Aqueles que são criados pelos avós envolvem estes, e não seus pais, nos processos que culminam nos seus casamentos ${ }^{356}$. Portanto, ao menos parte das uniões de Ordem 1012, em que Ego contraiu união com uma prima cruzada de

\footnotetext{
${ }^{355}$ Há um total de 18 casamentos na rede em que Ego e Alter poderiam, por ser possível traçar sua relação apenas por laços de filiação materna, ser co-residentes antes do casamento. Estes casos se concentram em uniões que envolvem um homem e uma mulher de mesma geração ou descendente. Os únicos casos ascendentes são de ordem 1013.

${ }^{356}$ Este é um ponto importante, pois os homens geralmente entregam seus filhos para serem criados pelos seus pais que habitam em outra casa, já as mulheres entregam para seus pais que são co-residentes, fazendo com que a adoção só ganhe visibilidade quando o matrimônio torna-se uma questão relevante.
} 
um de seus pais genealógicos, podem ter relação com a prática de adoção, ou seja, netos que se transformam em filhos casam com as primas cruzadas de seus pais-irmãos.

Os casos de Ordem 1013 correspondem a 51 percursos, distribuidos por 21 tipos diferentes, muitos dos quais são únicos, isto é, só há um casamento em que Alter é atingido através de determinado tipo de vinculo genealógico. Vemos nas tabelas a seguir que, embora os casos mais comuns correspondam a casamentos entre parentes cruzados, os paralelos apresentam maior regularidade na distribuição. A questão residencial parece perder sua relevância, existindo o casamento entre pessoas que poderiam, pela aplicação da regra de residência, ser co-residentes, porém não observamos em campo nenhum caso em que os descendentes de um ancestral situado em $\mathrm{G}+4$ e $\mathrm{G}+3$ dividissem uma mesma casa.

\begin{tabular}{|cccc|}
\hline \multicolumn{4}{|c|}{ Tabela 14-Percursos cruzados 1013} \\
\hline \multicolumn{3}{|c|}{ Ordem $1013-7$} & conexões - Cruzados \\
\hline Ordem & Drav & Percursos & Num \\
\hline 1013 & $\mathrm{X}$ & FMMFSSD & 7 \\
\hline 1013 & $\mathrm{X}$ & FMMMSSD & 7 \\
\hline 1013 & $\mathrm{X}$ & FFFFDDD & 2 \\
\hline 1013 & $\mathrm{X}$ & FFFMDDD & 2 \\
\hline 1013 & $\mathrm{X}$ & MMMFDSD & 1 \\
\hline 1013 & $\mathrm{X}$ & MMMMDSD & 1 \\
\hline
\end{tabular}

\begin{tabular}{|cccc|}
\hline \multicolumn{4}{|c|}{ Tabela 15-Percursos paralelos 1013} \\
\hline \multicolumn{4}{|c|}{ Ordem $1013-7$ conexões - Paralelos } \\
\hline Ordem & Drav & Kin Type & Num \\
\hline 1013 & $\mathrm{P}$ & MMMFDDD & 4 \\
\hline 1013 & $\mathrm{P}$ & MFFFDDD & 3 \\
\hline 1013 & $\mathrm{P}$ & MFFFSSD & 3 \\
\hline 1013 & $\mathrm{P}$ & MFFMDDD & 3 \\
\hline 1013 & $\mathrm{P}$ & MFFMSSD & 3 \\
\hline 1013 & $\mathrm{P}$ & MMMFSSD & 3 \\
\hline 1013 & $\mathrm{P}$ & MMMMSSD & 3 \\
\hline 1013 & $\mathrm{P}$ & MMMMDDD & 2 \\
\hline 1013 & $\mathrm{P}$ & FFFFSDD & 1 \\
\hline 1013 & $\mathrm{P}$ & FFFMSDD & 1 \\
\hline 1013 & $\mathrm{P}$ & FFMFSSD & 1 \\
\hline 1013 & $\mathrm{P}$ & FFMMSSD & 1 \\
\hline 1013 & $\mathrm{P}$ & FMFFDDD & 1 \\
\hline 1013 & $\mathrm{P}$ & MFMFDSD & 1 \\
\hline 1013 & $\mathrm{P}$ & MFMMDSD & 1 \\
\hline
\end{tabular}

Em numeros absolutos, predominam os percursos paralelos (31 de 51), mas estes são mais variados que os cruzados, que se concentram em dois tipos de percursos, quase duas vezes mais frequentes do que os paralelos mais comuns. Talvez, os vínculos que apresentam apenas um caso sejam frutos da distorção que ocorre quando há a adoção pelos avós, mas este é um dado que não pudemos obter em campo. Se uma relação de filiação fosse obliterada, tanto na linha de Ego quanto de Alter, as relações entre eles seriam diferentes, pois ambos se situariam, assim, em uma mesma geração. Tanto se o marido fosse para $\mathrm{G}+1$, geração em que se situa a esposa, quanto se a mulher passasse 
para $\mathrm{G}+2$, eles passariam a ser de uma mesma geração, já que, neste último caso Alter estaria em uma geração que é estruturalmente equivalente a geração de Ego.

Se observarmos a relação entre os parentes de ligação em cada nível geracional, vemos que há uma pequena preferência para vínculos que passam por uma relação de sexo oposto entre as pessoas de $\mathrm{G}+3$ e $\mathrm{G}+2$ e uma relativa indiferença em $\mathrm{G}+1$, ou seja, há quase um mesmo número de percusos que se iniciam pelo pai ou pela mãe de Ego. Isto quer dizer que, em $\mathrm{G}+3$, os vinculos passam mais comumente por uma relação entre irmão e irmã, e em G+2, por primos de sexo oposto. A tabela abaixo apresenta as frequências, mostrando essas preferências, e na sequência está o modelo relacional detalhado.

Tabela 16 - Relação de sexo dos parentes de ligação

\begin{tabular}{|c|cc|}
\hline Geração & Sexo oposto & Mesmo sexo \\
\hline$G+3$ & $33(65 \%)$ & $18(35 \%)$ \\
\hline$G+2$ & $34(67 \%)$ & $17(33 \%)$ \\
\hline$G+1$ & $23(45 \%)$ & $28(55 \%)$ \\
\hline
\end{tabular}

Tabela 17 - Cruzamento de Alter em relação aos pais de EGO

\begin{tabular}{|l|c|c|c|c|c|c|c|c|}
\hline $\mathrm{G}+3$ & $\mathrm{P}$ & $\mathrm{P}$ & $\mathrm{X}$ & $\mathrm{X}$ & $\mathrm{P}$ & $\mathrm{P}$ & $\mathrm{X}$ & $\mathrm{X}$ \\
$\mathrm{G}+2$ & $\mathrm{P}$ & $\mathrm{X}$ & $\mathrm{P}$ & $\mathrm{X}$ & $\mathrm{P}$ & $\mathrm{X}$ & $\mathrm{P}$ & $\mathrm{X}$ \\
$\mathrm{G}+1$ & $\mathrm{X}$ & $\mathrm{X}$ & $\mathrm{X}$ & $\mathrm{X}$ & $\mathrm{P}$ & $\mathrm{P}$ & $\mathrm{P}$ & $\mathrm{P}$ \\
\hline Numero de repetições & 0 & 2 & 3 & 18 & 14 & 2 & 0 & 12 \\
\hline Cruzamento de Alter em relação a F/M & $\mathrm{P}$ & $\mathrm{X}$ & $\mathrm{X}$ & $\mathrm{P}$ & $\mathrm{P}$ & $\mathrm{X}$ & $\mathrm{X}$ & $\mathrm{P}$ \\
\hline
\end{tabular}

Apresentamos, acima, todas as possibilidades combinatórias dos cruzamentos entre os pais de Ego e Alter, mas há não são todas que ausentes na rede, havendo, também, uma diferença na distribuição dos casos existentes. Como podemos observar na tabela, embora a quantidade seja semelhante, há uma diferença entre os percursos que partem do pai $(\mathrm{G}+1=\mathrm{X})$ e da mãe $(\mathrm{G}+1=\mathrm{P})$ de Ego. Em ambos os casos, Ego casou-se, na maioria das vezes $(86 \%)$, com uma prima paralela de seus pais, segundo o cálculo dravidiano, mas há uma diferença fundamental. Todos os percursos que resultam no casamento com uma prima paralela do pai passam, necessariamente, por alguma relação intergeracional de sexo oposto, isto é, nenhum dos percursos que 
passam pelo pai de Ego inclui relações de irmãos de mesmo sexo $(\mathrm{G}+3)$ e de primos de primeiro grau de mesmo sexo $(\mathrm{G}+2)$ nas gerações ascendentes.

A diferença é que Ego parece ser equivalente ao seu próprio pai, porém, antes de demonstrar, é necessário entender porque, no cálculo dravidiano, há duas possibilidades combinatórias que resultam na existência de primos paralelos. Para dado Ego, as relações que resultam em primos paralelos de segundo grau são de dois tipos: ou todas as gerações ascendentes apresentam relações entre pessoas de mesmo sexo; ou ambas as gerações são compostas por relações de sexo oposto. Como chama a atenção Silva (1995), para o modelo de cruzamento Dravidano A, que está na base da análise dos cruzamentos da MaqPar, pessoas de mesmo sexo sempre reproduzem a sua relação, isto é, consanguineos de mesmo sexo produzem consanguíneos e afins produzem afins, ou seja irmãos de mesmo sexo em $\mathrm{G}+3$ e primos paralelos de mesmo sexo em G+2 geram primos paralelos em $\mathrm{G}+1$. Quando passamos para as relações de sexo oposto a situação se inverte, pois os descendentes de consanguínos de sexo oposto são, entre si, afins, porém, se tivermos novamente uma relação de sexo oposto, estas pessoas poderiam se casar e seus filhos voltariam a possuir o status de paralelos entre si.

Vimos no capítulo anterior que, o parentesco Deni se estrutura de forma diferente, pois nem sempre afins de sexo oposto produzem consanguíneos e isto parece ser especialmente importante para os casamentos de Ordem 1013. A equivalência entre Ego e seu pai pode ser percebida quando consideramos os dados a partir do modelo dravidiano Deni. Neste, os filhos de consanguineos de mesmo sexo são inegavelmente interditos, já os descentes de afins de sexo oposto não são interditos, exceto se forem também descentes de consanguineos de mesmo sexo, ou seja, posições que seriam paralelas no dravidiano clássico, se mantêm cruzadas no modelo Deni. Neste caso, Ego se casa com mulheres que, embora devessem ser paralelas segundo o canone, são de fato cruzadas na perspectiva Deni.

No caso dos vínculos que passam pela mãe de Ego, a situação se altera sensivelmente. Embora, tal como acontece com o pai, um dos tipos de primas paralelas de segundo grau da mãe pode ser na realidade cruzado, grande parte das uniões ocorrem com mulheres que são, incontestavelmente, primas paralelas da mãe. De qualquer maneira, a grande maioria dos casamentos de Ego, contados a partir da relação com sua mãe, ocorrem com as primas paralelas desta, ou seja, Ego casa com mulheres que são afins do ponto de vista de seu pai, com as quais a própria mãe possui certa distância. 
Isto não quer dizer que a mãe de Ego seja uma afim para ele, mas que, tal como mostramos ao longo desta tese, há semelhança perspectiva entre pai e filho.

É curioso que, a linha de parentes colaterais que se origina de um ancestral em G+4 é posta por Koop \& Lingenfelter (1983) como limite, a partir do qual não se reconhecem vínculos consanguíneos. Os autores apontam, contudo, que a extensão só seria consistente para as relações entre pessoas que se ligam por cadeias de filiação masculina, já as relações traçáveis pelas mulheres teriam maior probabilidade de serem tornadas afins. Segundo o gráfico dos autores, para Ego, os parentes colaterias de G+1, que descendem de um ancestral em G+4, mantêm sua característica de consanguíneo, mas seus ascendentes $(\mathrm{G}+2)$ e descendentes $(\mathrm{G} 0)$ se situam na afinidade. Se este é o limite de reconhecimento do parentesco, vimos que a rede empírica se assenta no modelo Deni de que pai e filho são uma só e mesma coisa, podendo um tormar o lugar do outro na estrutura matrimonial. Desta forma a regra seria respeitada se assumissemos que o filho pode tomar a perspectiva do pai. O gráfico apresentado pelos autores é o seguinte: 
Figura 18 - A profundidade linear e a extensão colateral dos vínculos agnáticos

\section{Geraçōes}

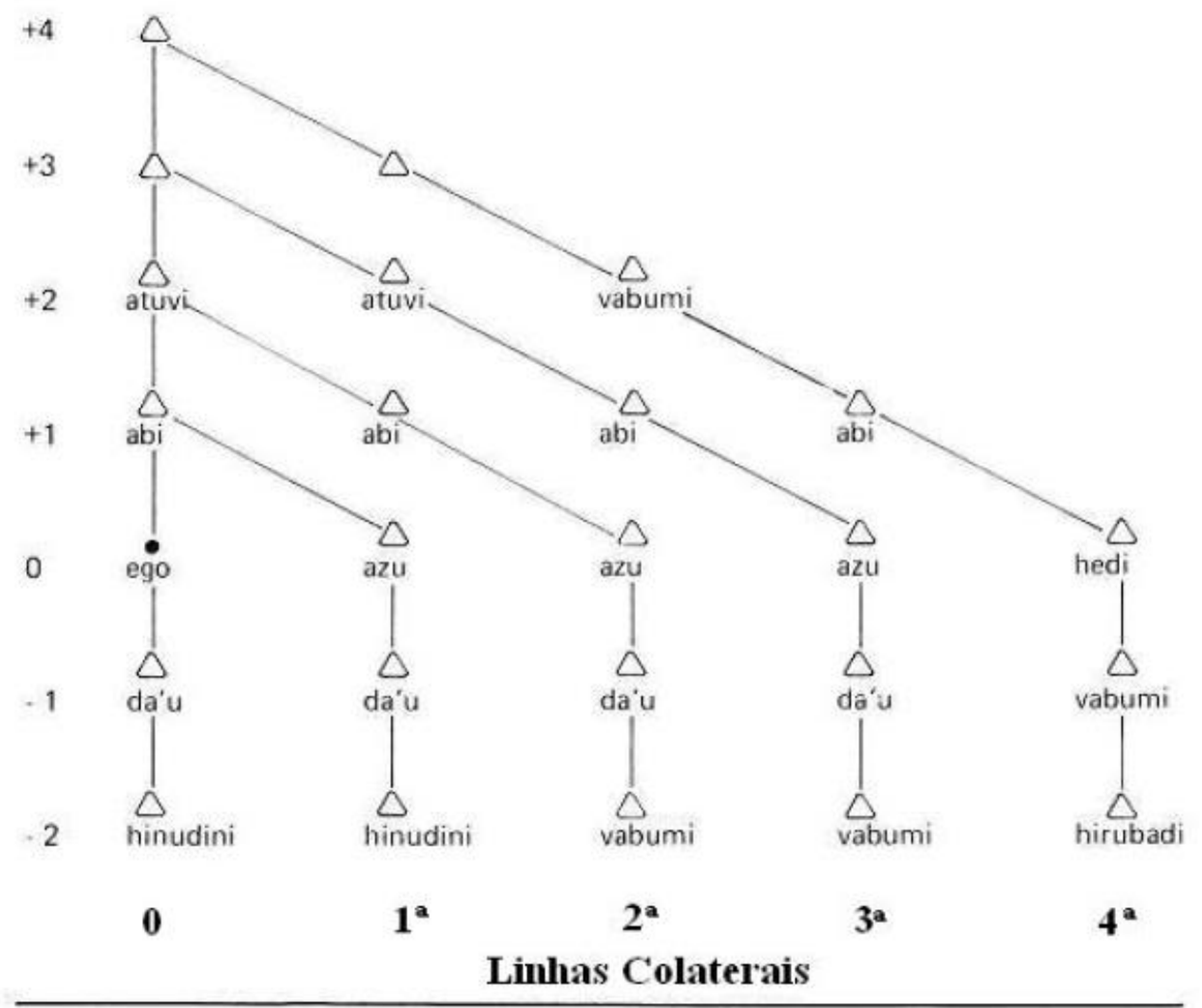

(adaptado de Koop \& Ligenfelter 1980: 24)

A figura acima representa o limite da contagem de parentesco entre os Deni (Koop \& Lingenfelter 1983:29), a partir das linhas de parentes masculinos que se originam em G+4 não há consanguíneos colaterais. A linha de $4^{\mathrm{a}}$ grau de colateridade representa o limiar a partir do qual, segundo as afirmações desses autores, nossas próprias observações em campo e a questão da multiplicação de casos de endogamia de identidade de transmissão paterna, os vínculos genealógicos deixam de ser relevantes. Podemos considerar que os ancestrais de $\mathrm{G}+5$ ou mesmo $\mathrm{G}+6$ foram obtidos durante nossa pesquisa devido a sua relevância para o casamento dos velhos que se situam em outras profundidades genealógicas em relação a eles, sendo sua memória relevante para eventos matrimoniais recuados no tempo, mas não para os recentes.

A Ordem 1014, a $5^{\mathrm{a}}$ mais comum, se origina de um ancestral em $\mathrm{G}+5$ e poderia ser considerada como composta, inteiramente, por parentes cruzados, pois ela 
ultrapassaria a aplicação do modelo Deni de parentesco consanguíneo. Poderíamos dizer o mesmo para os casamentos com percursos de Ordem 2005, que envolvem as filhas de 1014, mas neste caso há uma tendência aos casamentos entre parentes paralelos maior do que seria esperado no caso de serem aleatórios. Esta primazia em 2005, talvez possa ser entendida a partir da consideração de que são percursos que envolvem os primos de segundo grau dos avós e a totalidade dos percursos (32) desta Ordem se iniciam com pares de irmãos de sexo opostos $(\mathrm{B} / \mathrm{Z}$ em $\mathrm{G}+4$, estruturalmente equivalentes a $\mathrm{B} / \mathrm{Z}$ em G0 e $\mathrm{G}+2$ ), ou seja em $\mathrm{G}+3$ todos os vínculos passam por pessoas que são primos cruzados.

Os percursos de Ordem 2005 (também de Ordem 1024 com 4 casos na amostra e de 3024 com 5) constituem o limite de decomposição da rede pelo método empregado, atingindo 10 conexões. Como mostramos anteriormente, a maioria dos casos ficam entre 4 e 9 conexões, sendo mais frequente entre as ordens de G0 e G-1, por isso, iremos considerar, agora, os percursos que envolvem os casamentos com mulheres de G-1. Anteriormente, já expusemos que, em todos eles, há uma tendência aos noivos serem paralelos entre si, embora estas uniões sejam apenas um pouco mais frequentes que as cruzadas.

De forma geral, todos os casamentos em G-1 correspondem a uniões impróprias, cujos cônjuges estão condenados a serem devorados por Hamu, mas o detalhamento dos casos permite explicitar algumas tendências que tornam mais claras certas caractetisticas do parentesco Deni. A rede apresenta 204 anéis que situam Alter em G-1, destes, $108(53 \%)$ correspondem a uniões paralelas segundo o cálculo de cruzamento dravidiano. Este dado parece reforçar a noção de que este parâmetro é irrelevante para estas uniões, porém, é possível verificar certas distorções na distribuição dos casos que não ocorreriam caso fossem aleatórias.

A Ordem 3012 está envolvida em 36 anéis (24 paralelos e 12 cruzados), que se distribuem por todos os 16 tipos percursos possíveis entre Ego e Alter, isto é, há casamentos com as filhas de todas as posições de parentesco (kin types) para primos. Como limitamos a análise aos casos em que os 4 avós de ambos os cônjuges são conhecidos, os resultados aparecem em sua maioria duplicados, pois, ora o acenstral de ambos é contado por uma mulher (avó de Ego e bisavó de Alter), ora por um homem (avô de Ego e bisavô de Alter), havendo exceções, apenas, quando há uma relação de meio irmãos em $\mathrm{G}+1$. Na figura abaixo representamos todos os casos encontrados, 
sendo que os números abaixo de Alter indicam a quantidade de percursos, a esquerda os casos que o ancestral em comum é um homem e a direita uma mulher, e por fim o cruzamento, segundo o cálculo dravidiano.

Figura 19 - Casamentos da Ordem 3012
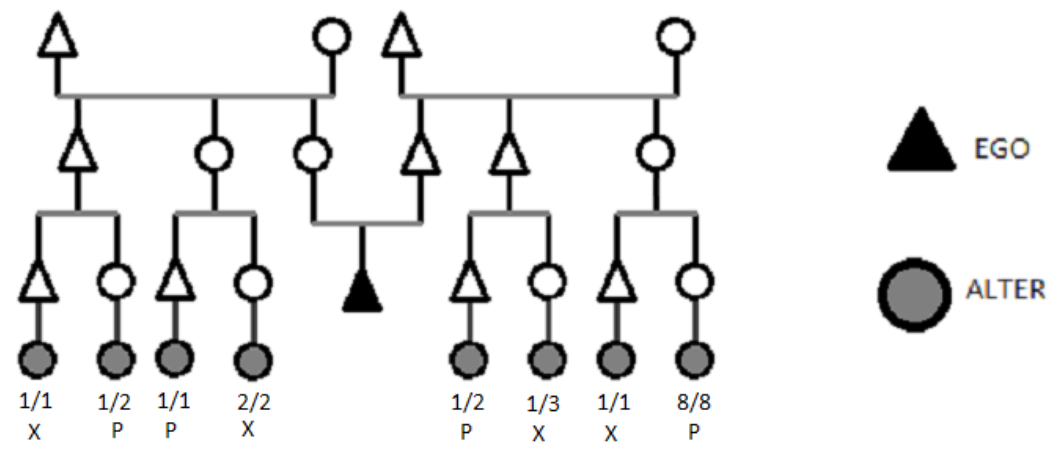

Embora a maior parte dos casamentos apareça como paralelo, há uma clara preferência pelo matrimônio com a filha da prima cruzada patrilateral (FZDD). Isto pode ser entendido de duas formas, já que duas características do parentesco Deni tornariam esta posição cruzada e, portanto, casável. Em primeiro lugar, temos o princípio de que filhos de parentes afins são afins, exceto quando são, também, filhos de consanguíneos, logo, as primas cruzadas, não casadas com “irmãos” de Ego, produzem afins (casáveis) em relação a este último. Isto, contudo, não explicaria porque há uma preferência patrilateral, pois a prima cruzada matrilateral (MBD) também geraria mulheres afins.

A outra possibilidade seria a equivalência perspectiva entre pai e filho, que, sob certos aspectos, como mostramos em diversos momento desta tese, podem ser considerados como indistintos: são um mesmo_madi e _deni, mesmo semên/corpo, veem da mesma forma os consanguíneos mais novos do que eles ( $\mathrm{yB}=\mathrm{S}=$ shuvi, $\mathrm{yZ}=\mathrm{Z}=i n u$ ), etc.. A questão não é que eles sejam parentes (uvibuva), pois esta relação se estabelece indistintamente entre homens e mulheres genealogicamente próximos, mas que eles podem ver outros parentes da mesma forma. A equivalência estrutural entre Ego e seu pai, e não de Alter e sua mãe, torna-se evidente quando considerarmos as duas possibilidades. É obvio que só podemos traçar uma equivalência para Ego (Ego = F), mas para Alter seria possível quatro equivalências, uma para cada um dos tipos de 
primas, os 4 kintypes femininos de mesma geração de Ego com 4 conexões entre eles (Alter $\approx$ FBD ou FZD ou MZD ou MBS).

A frequência de percusos que envolvem o casamento com a filha de uma prima cruzada é maior do que as outras, assim, iremos restringir as equivalências de Alter às duas primas cruzadas de Ego, a matrilateral (MBS) e a patrilateral (FZD). Nosso objetivo é explicitar porque há uma desproporção dos casamentos com filha da prima cruzada patrilateral em relação aos outros.

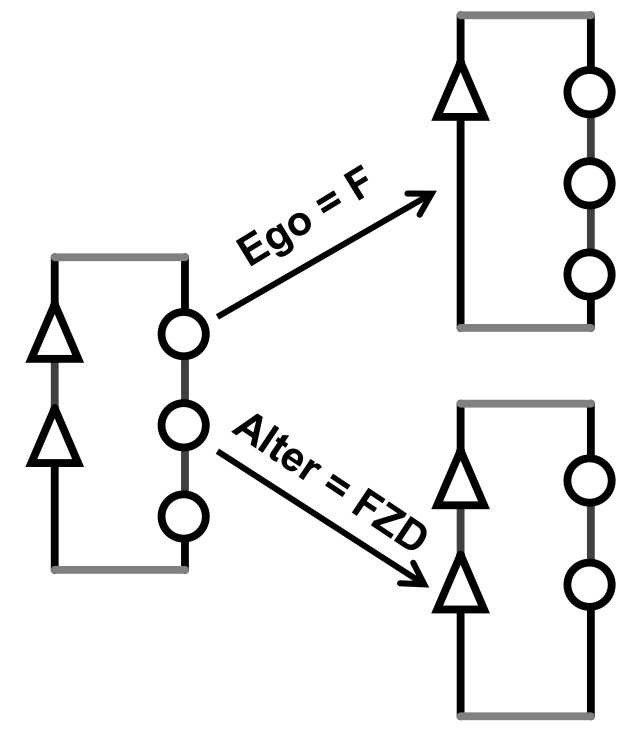

Quando Ego assume a posição de seu pai, Alter passa para a segunda geração descendente $(\mathrm{G}-2)$. A relação entre eles se torna MMB-ZDD, que, como mostramos no capítulo anterior, equivale àquela entre os cunhados, entre cruzados de sexo oposto e mesma geração. Através dessa equivalência, os cônjuges passam a ser parentes casáveis conforme a regra.

Neste caso, se Alter assumisse a posição de sua mãe, passaria para a geração de Ego (G0), tonando-se sua prima cruzada patrilateral (FZD). Aqui, também, a relação entre eles passaria de paralela de gerações adjacentes para cruzada de mesma geração, sendo apropriada a união. $\mathrm{O}$ mesmo pode ser dito quando a equivalência feminina é feita no lado matrilateral, pois, também neste caso, a relação entre marido e esposa seria de primos cruzados, isto é, seriam parentes não interditos. 
Se o ponto fosse a equivalência feminina, não seria possível explicar porque há

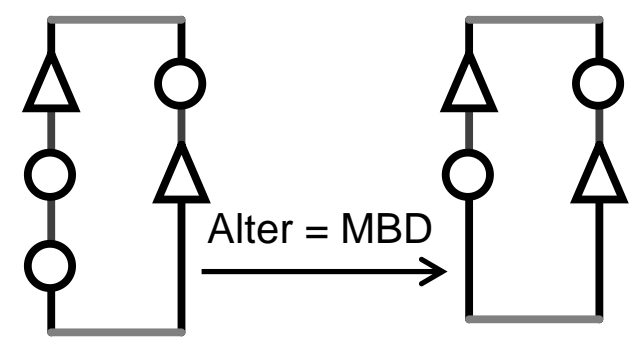
uma preferência patrilateral $^{357}$, já que ocorreria o mesmo fenômeno que observamos no lado paterno. A filha de uma prima cruzada matrilateral, se for equivalente a mãe, torna-se também uma prima cruzada, não havendo motivos para a baixa frequência dessas uniões em comparação com o lado patrilateral. Se tentarmos equacionar Ego e seu pai e seguir pelo lado materno, encontramos uma dificuldade inicial, pois a mãe é a esposa do pai, assim uma pessoa que é inegavelmente um parente consangúineo (a irmã da mãe é sempre uvibuva) assumiria um potencial para ser afim, que não condiz com o modelo Deni. Acima dissemos que isto não ocorreria quando a relação é com a prima da mãe de Ego, porque, naqueles casos, havia maior separação genealogica entre Ego e Alter, entre a mãe de Ego e Alter e a distância sempre é relevante no parentesco Deni.

As Ordens 3013 e 3014 apresentam uma distribuição muito variada. As posições de parentesco de Alter possuem frequências de casos que aumentam progressivamente (alguns com 1, outros com 2, 3, 4, 5 e 6 ocorrências), sendo impossível delinear um claro padrão. Os percursos existentes na rede para estas Ordens são:

\footnotetext{
${ }^{357}$ Nos percursos de ordem 2002, isto é, em que há o casamento de primos cruzados genealógicos, não há qualquer preferência de lado. Os percursos cruzados e suas frequências são: para a prima cruzada patrilateral (FZD) FFDD - 21 e FMDD - 20; e para a matrilateral (MBD) MFSD - 18 e MMSD - 19.
} 


\begin{tabular}{|ccc|}
\hline \multicolumn{3}{|c|}{ Tabela 18 - Ordem 3013} \\
\hline Percurso & Drav & Num \\
\hline FFFDSDD & $\mathrm{P}$ & 1 \\
\hline FFFSSSD & $\mathrm{P}$ & 1 \\
\hline FFMDSDD & $\mathrm{P}$ & 1 \\
\hline FFMSSSD & $\mathrm{P}$ & 1 \\
\hline FMFDSSD & $\mathrm{P}$ & 1 \\
\hline FMMDSSD & $\mathrm{P}$ & 1 \\
\hline MMMDDSD & $\mathrm{P}$ & 1 \\
\hline FMFDDDD & $\mathrm{P}$ & 2 \\
\hline FMMDDDD & $\mathrm{P}$ & 2 \\
\hline MMFDSDD & $\mathrm{P}$ & 2 \\
\hline MMMDSDD & $\mathrm{P}$ & 2 \\
\hline MMFDDSD & $\mathrm{P}$ & 3 \\
\hline MMMSSSD & $\mathrm{P}$ & 3 \\
\hline MMFSDDD & $\mathrm{P}$ & 4 \\
\hline FFFDDSD & $\mathrm{P}$ & 5 \\
\hline FFMDDSD & $\mathrm{P}$ & 5 \\
\hline MFFDDDD & $\mathrm{P}$ & 5 \\
\hline MFMDDDD & $\mathrm{P}$ & 5 \\
\hline MMFSSSD & $\mathrm{P}$ & 6 \\
\hline FFFSSDD & $\mathrm{X}$ & 1 \\
\hline FFMSSDD & $\mathrm{X}$ & 1 \\
\hline FMFSDDD & $\mathrm{X}$ & 1 \\
\hline FMFSSSD & $\mathrm{X}$ & 1 \\
\hline MFFDDSD & $\mathrm{X}$ & 1 \\
\hline MFFSDDD & $\mathrm{X}$ & 1 \\
\hline MFMDDSD & $\mathrm{X}$ & 1 \\
\hline MMFSDSD & $\mathrm{X}$ & 1 \\
\hline FMFDSDD & $\mathrm{X}$ & 2 \\
\hline FMMDSDD & $\mathrm{X}$ & 2 \\
\hline MMFSSDD & $\mathrm{X}$ & 2 \\
\hline MMMDDDD & $\mathrm{X}$ & 2 \\
\hline MMMSSDD & $\mathrm{X}$ & 2 \\
\hline FFFDDDD & $\mathrm{X}$ & 3 \\
\hline FFMDDDD & $\mathrm{X}$ & 3 \\
\hline FMFDDSD & $\mathrm{X}$ & 3 \\
\hline FMMDDSD & $\mathrm{X}$ & 3 \\
\hline MMFDDDD & $\mathrm{X}$ & 4 \\
\hline
\end{tabular}

\begin{tabular}{|ccc|}
\hline \multicolumn{3}{|c|}{ Tabela 19 - Ordem 3014} \\
\hline Percurso & Drav & Num \\
\hline FMMFSDSSD & $\mathrm{P}$ & 1 \\
\hline MFFFDDSSD & $\mathrm{P}$ & 1 \\
\hline MFFMDDSSD & $\mathrm{P}$ & 1 \\
\hline FFFFDDDSD & $\mathrm{P}$ & 2 \\
\hline FFFMDDDSD & $\mathrm{P}$ & 2 \\
\hline FMFFSSSSD & $\mathrm{P}$ & 2 \\
\hline FMFMSSSSD & $\mathrm{P}$ & 2 \\
\hline MFFFDDSDD & $\mathrm{P}$ & 2 \\
\hline MFFMDDSDD & $\mathrm{P}$ & 2 \\
\hline FMFFDDSDD & $\mathrm{P}$ & 4 \\
\hline FMFMDDSDD & $\mathrm{P}$ & 4 \\
\hline FFFFDDDDD & $\mathrm{P}$ & 5 \\
\hline FFFMDDDDD & $\mathrm{P}$ & 5 \\
\hline FMFFDDDSD & $\mathrm{X}$ & 1 \\
\hline FMFMDDDSD & $\mathrm{X}$ & 1 \\
\hline MFFFDDDDD & $\mathrm{X}$ & 1 \\
\hline MFFFDDDSD & $\mathrm{X}$ & 1 \\
\hline MFFMDDDDD & $\mathrm{X}$ & 1 \\
\hline MFFMDDDSD & $\mathrm{X}$ & 1 \\
\hline MFMFSSSSD & $\mathrm{X}$ & 1 \\
\hline MMFFDDSDD & $\mathrm{X}$ & 1 \\
\hline MMFFDDSSD & $\mathrm{X}$ & 1 \\
\hline MMFMDDSDD & $\mathrm{X}$ & 1 \\
\hline MMFMDDSSD & $\mathrm{X}$ & 1 \\
\hline MMMFSSDD & $\mathrm{X}$ & 1 \\
\hline MMMMSSDDD & $\mathrm{X}$ & 1 \\
\hline FFFFDDSDD & $\mathrm{X}$ & 2 \\
\hline FFFFSDDDD & $\mathrm{X}$ & 2 \\
\hline FFFFSSSSD & $\mathrm{X}$ & 2 \\
\hline FFFMDDSDD & $\mathrm{X}$ & 2 \\
\hline FFFMSDDDD & $\mathrm{X}$ & 2 \\
\hline FFFMSSSSD & $\mathrm{X}$ & 2 \\
\hline FMMMSDDDD & $\mathrm{X}$ & 2 \\
\hline FFFFDDSSD & $\mathrm{X}$ & 3 \\
\hline FFFMDDSSD & $\mathrm{X}$ & 3 \\
\hline FMMFSDDDD & $\mathrm{X}$ & 3 \\
\hline FMMFSSSSD & $\mathrm{X}$ & 7 \\
\hline FMMMSSSSD & $\mathrm{X}$ & 7 \\
\hline
\end{tabular}

A progressão, mesmo que gradual, sugere que estes casamentos não ocorrem de maneira aleatória. Se não sofressem nenhuma influência, haveria uma distribuição regular, o que não se observa, pois alguns percursos são 6 (3013) ou 7 (3014) vezes mais frequentes do que os menos comuns. Provavelmente, o que ocorre é que, no caso da Ordem 3013, há uma grande quantidade de parâmetros que influenciam os 
casamentos, pois as esposas correspondem às descendentes da Ordem (2003), em que recai a maior parte dos casamentos. As mulheres de 2013 são pessoas que podem ser tidas como cônjuges preferidos quando não ocorre a união entre Ego e a mãe de Alter, ou são filhas daqueles que são cunhados. A questão pode ser a redução da distância, pois, como afirmou Viverios de Castro (2002), os casamentos na amazônia são processos de consanguinização da afinidade. Entre os Deni, as linhas que se originam em $\mathrm{G}+3$ parecem ser as preferidas para ocorrer o matrimônio, para evitar que os consanguíneos distantes tornem-se afins distantes, eles são transformados em afins próximos e, desta maneira, podem ser consanguinizados.

A Ordem 3014 apresenta uma caracteristica interessante, pois os percursos que partem do pai (66) de Ego são muito mais frequentes do que aqueles que partem da mãe (17) e isto não seria justificável pela maior lembraça dos vínculos de paternidade $(99,01 \%)$ do que de maternidade $(98,39 \%)$. Talvez, mais uma vez, seja a influência dos dois parâmetros que parecem ser mais atuantes na média distância genealógica, pois, se Ego equivale ao seu pai, estes casamentos estariam relacionados, em certa medida, com a Ordem 2003 (a mais frequente de todas) contada a partir do pai de Ego (1013 para Ego). De qualquer maneira, a Ordem 3014 envolve 9 conexões genealógicas e, nesta distância, poderíamos imaginar que a maior frequência de percursos contados a partir do pai de Ego seja mera coincidência. 


\section{Considerações finais}

Mostramos nesta tese como o parentesco Deni não pode ser entendido como uma parte separada de sua cultura, estando relacionado com diversos aspectos. Investigamos as relação entre alguns aspectos da cosmologia Deni e as práticas do parentesco, ou seja, apresentamos as conexões existentes entre ideia e prática, como diferentes aspectos da sociocosmologia influenciam o regime matrimonial. Para atingir esse objetivo abordamos diversos aspectos do cosmos que, a princípio, não aparecem relacionados ao parentesco.

No capítulo 1 debatemos alguns aspectos dos regimes temporais Deni que podem ser relacionada com algumas características da terminologia de parentesco, no que tange das narrativas sobre o passado e a terminologia para avós e pessoas muito velhas. Entre os Deni, tornar-se avô corresponde a ter conhecimento, isto é, quando passam a receberem o termo avô, alguém assume uma posição que o torna um emissor legítimo de conhecimento. Eles são aqueles capazes de informar sobre o tempo dos antigos, de fazer a conexão entre o presente e o passado, o que se materializa pela indistinção terminológica em relação a seus ascendentes. Vimos que há três tempos na cosmologia Deni, o do inicio que é diferente quantitativamente e qualitativamente do presente, o tempo passado, similar ao presente, e o tempo presente.

Os avós são aqueles que tomaram parte ativa do tempo passado e, portanto, são seus conhecedores, bem como todos os idosos com quem os jovens estão em contato. Os velhos não são pareceiros sexuais e/ou matrimoniais e vimos que isto está presente na genealogia, não existindo casamentos com muitas gerações de diferença. Todas as pessoas muito velhas, isto é, que não se tornarão novamente cônjuges, passam a ser espécies de consanguíneos, pessoas não casáveis, recebendo os mesmos termos que os avós, e, como tais, passam a participar do "Nós" para as pessoas. Neste momento eles obtém a capacidade de fazer a ligação entre os vivos (jovens) e os mortos, o presente cotidiano e o passado remoto.

Mostramos, a partir da discussão sobre as narrativas, como pessoas situadas em G+3 ou G+4 são colocadas no tempo dos antigos, sendo descoladas do tempo presente. Esta mesma separação pode ser percebida em relação a genealogia, mas o ponto de referência está nos pais de Ego, que se envolvem em suas escolhas matrimoniais, ou seja, os ancestrais de $\mathrm{G}+4$ ( $\mathrm{G}+3$ dos pais) estão no limite a partir do qual as relações 
genealógicas entre os cônjuges não possuem importência, sua ligação seria informada pela descendência comum dos antigos.

No capítulo 2 passamos a abordar a forma como os Deni constroem coletivos humanos e não humanos através da formação de entidades supra indivuais. O processo é o de apagar as diferenças, que só existem quando surgem outras entidades, isto é, o corpo Deni é formado por várias almas, mas se o foco recai sobre esta variação, a unidade do corpo deixa de existir. Vimos que, na genealogia, muitos aspectos só podem ser entedidos se considerarmos que o pai e o filho podem formar uma dessas entidades, cuja perspectiva permite apreender certas mulheres como casáveis, o que não ocorreria no caso das perspectivas estarem separadas.

Como mostramos no capítulos 2 , os afins efetivos são retirados dos campo dos inimigos, as relações sexuais, comportamento entre afins, transforma inimigos em parentes em potencial. Ao considerarmos as terminologias de parentesco, mostramos que a afinidade é ciclíca, não se mantendo enquanto um conjunto de outros com os quais as relações matrimoniais são proibidas, todos são ou conjuges potenciais da própria pessoa, ou dos seus consanguíneos imediatos. A terminologia não aponta uma separação absoluta, que se manifestaria em uma linha de afins separado da linha dos consanguíneos, mas ela constroi um universo relacional em que qualquer potencialmente não parente pode se consanguinizado.

Estas características da terminologia, que foram abordadas no capítulo 3, se expressam na genealogia em muitos momentos. Se lembrarmos que o casamento é uma relação odorífica e que certos cheiros, transmitidos com as relações sexuais, não podem ser acumulados na pessoa, são linhas de ordores diferentes que mantêm a possibilidade de se relacionarem. Na genealogia, vimos que há uma relação importante entre a distância dos vínculos de parentesco e a regra de cruzamento de primos cruzados. Pessoas com parentesco próximo, isto é, pessoa cuja separação odorífica não é muito grande, casam mais conforme a regra de cruzamento dravidiano.

Para os Deni, corpos assemelhados possuem cheiro parecido, sendo que os filhos, cujo corpo é constituido a partir de parcelas do pai, obtem deste parte de seu cheiro. As mulheres, ao não participar atividade da constituição corporal do feto, não transmite muito de seu cheiro para este. Os filhos de dois irmãos de sexo oposto possuem cheiros muito diferentes, logo a proximidade genealógica entre os cônjuges é 
acompanhada pela diferença de seus cheiros. No caso dos parentes genealogicamente distantes, mesmo que estejam em uma linha que compartilha o mesmo cheiro (descendem de um mesmo homem), após certo grau de afastamento, esta relação é enfraquecida, podendo as pessoas contrairem matrimônio entre si.

Durante a análise da genealogia, notamos que, tanto no casos das patrilinhas (que poderíamos mesmo chamar de grupos odoríficos) quanto nos casamentos consanguíneos (A1C1), o reconhecimento de ligações de parentesco que partem de parentes localizados em $\mathrm{G}+4$ obscurecem os padrões. Um relação situada nesta profundidade genealogica/temporal, torna o afastamento e a diferença de cheiros muito grande, tornando dificil apreender as influências que recaem sobre os casamentos. Este ponto é aquele em que os casamentos estão em uma distância máxima para ocorrerem, antes que o parentesco entre as pessoas esteja perdido e, o ideal, é casar de forma apropriada, mas casar com aqueles que no limite são parentes.

Mostramos que o limite da endogamia Deni está nos madiha, sendo os casamentos com outros indígenas tolerados e com os kariva evitados e condenados. As uniões matrimoniais estão situadas entre uma exogamia minima (mesmo cheiro), a partir dos inegavelmente parentes (uvibuva), isto é, os parentes lineares e os irmãos com quem nunca se casam; e a endogamia máxima, os humanos (madi) e no limite os humanizáveis (kariva). Os casamentos acontecem neste contínuo, tendendo a acontecerem mais frequentemente entre pessoas próximas, seja genealógica ou socialmente.

A análise da genealogia mostra que nos casos em que os vínculos são próximos, em que o ancestral comum é um avô ou bisavo de Ego, observa-se uma aplicação quase perfeita do modelo dravidiano de parentesco. A maior parte dos casamentos ocorre com mulheres G0 que são parentes cruzados de Ego, diminuindo a frequência de respeito a fórmula de cruzamento conforme o ancestral de ligação se situa em uma geração mais recuada. Após certa distância, passa a ser observada a aplicação das esquivalências entre gerações alternadas e, nestes casos, a aplicação dos cruzamentos está relacionado com as especificidades da terminologia de parentesco Deni.

Este não é o único eixo em que a distância aparece, já que ela também ocorre em relação ao conjunto de descentes patrilinhares e a residência. Os homens parecem ser os únicos responsáveis pela criação do corpo do filho, sendo que isto faz com que eles 
compartilhem uma identidade ou mesmo que seus corpos sejam uma distribuição (parte) desta coisa que se realiza inter-pessoalmente. Há uma necessidade de manter as pessoas relacionadas por vínculos masculinos separadas, sendo que, em dado momento, o afastamento torna irrelevante o compartilhamento de um ancestral que ligue marido e esposa exclusivamente por relação agnáticas.

Os vínculos uterinos, por sua vez, parecem não possuir uma relevância para a questão da endogamia, parecendo que, só são evitadas as uniões em que Ego e Alter seriam co-residentes, o que seria evidenciado pela ligação genealógica próxima traçada por relações matrilineares. A questão da moradia salienta que, não apenas deve existir distancia genealógica entre os cônjuges, mas que também é preciso haver um distanciamento social minimo. A exogamia de casa surge como um princípio operador que está relacionado mais com a prática do que com o modelo, já que as evitações parecem só alcançar as pessoas que de fato poderiam co-habitar desde o nascimento e não aquelas que potencialmente poderiam.

Parace que, toda a questão do parentesco Deni está relacionada com a distância ideal, sendo que, progressivamente, há uma mudança nos parâmetros em atuação conforme os cônjuges estão mais afastados. Primeiro, parece ser o cálculo de cruzamento dravidiano o único relevante, sendo que, a partir disto, ocorrem derivações que ora aproximam os distantes, ora distanciam os próximos. Há um trabalho para manter os cônjuges em determinada relação, o que se obtém a partir de rotações na forma com que se concebem os vínculos. O que ocorre é que, conforme aumenta a distância genealogica (ou social) entre Ego e uma mulher, a relação entre eles passa por outras considerações, havendo uma correlação de forças e não um estado anômico em que ficaria a critério individual escolher uma ou outra das opções. 


\section{Bibliografia}

AIKHENVALD, A. Y. - Language contact and language change in Amazonia. In: B. Blake \& K. Burridge (eds.) - Selected papers from the 15th International Conference of Historical Linguistics, Melbourne, 13-17 August 2001. Amsterdam: John Benjamins, 2003.

ALÉS, C. - Anger as a marker of love: The ethic of conviviality among the Yanomami. In: J. Overing \& A. Passes (Eds.) - The anthropology of love and anger: The aesthetics of conviviality in native Amazonia. London: Routledge, 2000.

ALtMANN, L. - Madija: Um Povo Entre a Floresta e o Rio. São Paulo: PUC, 1994. (Dissertação)

APARICIO SUÁREZ, M. - Los Suruaha: Universos Míticos y Miradas Etnográficas. Quito: Universidade Politécnica Salesiana, 2008. (monografia) - Panorama contemporâneo do Purus Indígena. In:

Gilton Mendes dos Santos (org.) - Álbum Purus. Manaus: EDUA, 2011. - Os Suruwaha e sua rede de relações. Uma hipótese sobre localidades e coletivos Arawa. In: M. AMOROSO \& G. M. dos SANTOS (orgs.) - Paisagens, Circuitos e Lugares na Amazônia. São Paulo: PROCAD/CAPES; PPGAS e CESTA/USP; PPGAS e NEAI/UFAM; Terceiro Nome, 2013.

AZEVEDO, A. M. H. - A Percepção Madiha dos 'Brancos' e seus Projetos: O processo de construção da Alteridade e as estratégias de relacionamento com o 'Outro', numa comunidade indígena brasileira. Manaus: UCES Manaus, 2007. (Monografia)

- Pessoas falantes, espíritos cantores, almas trovões: História, sociedade, xamanismo e rituais de auto envenenamento entre os Suruwaha da Amazônia ocidental. Berna: Universidade de Berna, 2012. (Tese)

BAMFORD, S. \& LEACH, J. (eds) - Kinship and Beyond: The Genealogical Model Reconsidered. Oxford: Berghahn Books, 2009.

BONILLA, O. - O bom patrão e o inimigo voraz: predação e comércio na cosmologia Paumari. Mana, 11(1), 2005a.

- Cosmologia a Organização Social dos Paumari. Revista de Estudos e Pesquisas. Brasília: FUNAI:CGEP/CGDOC, v.2 n.1, 2005b.

- Des proies si désirables. Soumission et prédation pour les Paumari d'Amazonie brésilienne. École des hautes études em sciences sociales, 2007. (Tese de Doutorado) 
BOURDIEU, P. - Esboço de uma Teoria da Prática. In: BOURDIEU, P. - Sociologia. São Paulo: Ática, 1994.

BUENO, A. C. V. - O Irantxe e Myky do Mato Grosso: um estudo do parentesco. São Paulo: FFLCH-USP, 2008. (Dissertação de Mestrado)

CANDAU, J. - La métamémoire ou la mise em récit du travail de mémoire. Paris: Centre Alberto Benveniste, 2009.

CARDOSO, A. A. I. - Nem Sina, Nem Acaso. A tessitura das migrações entre a Província do Ceará e o território amazônico (1847 - 1877). Fortaleza: Universidade Federal do Ceará, 2011. (Tese de Doutorado)

CARNEIRO DA CUNHA, M. M. - "Cultura" e cultura: conhecimentos tradicionais e direitos intelectuais. In: - Cultura com aspas. São Paulo: Cosac Naify, 2009 \& VIVEIROS DE CASTRO, E. B. Vingança e Temporalidade. In: Anuário Antropológico/85. Tempo Brasileiro: Brasília e Rio de Janeiro, 1986.

CASTELlO BRANCO, J. M. B. - O gentil acreano. Revista do instituto Histórico e Geográfico Brasileiro v. 207, 1950.

- Acreânia. Revista do Instituto Histórico e

Geográfico Brasileiro, v. 240, 1958.

CESARINO, P. - De duplos e estereoscópios: paralelismo e personificação nos cantos xamanísticos ameríndios. Mana 12(1), 2006.

- Oniska: A poética do mundo e da morte entre os Marubo da Amazônia Ocidental. Rio de Janeiro: Museu Nacional-UFRJ, 2008. (Tese de Doutorado)

CHANDLESS, W. - Ascent of the River Purûs. Journal of the Royal Geographical Society of London, n.36, 1866.

CHAVES, R. P. R. - Relatório Circunstanciado de Identificação e Delimitação da Terra Indígena Deni. Brasília: FUNAI - Unesco, 2001.

CLASTRES, P. - A Sociedade Contra o Estado. São Paulo: Francisco Alves, 1990 [1974].

COHN, C. \& SZTUTMAN, R. - O visível e o invisível na guerra ameríndia. Revista Sexta-Feira, 7 [Guerra], 2003.

COUTINHO, João Martins da Silva - Relatório de Exploração do Rio Purus. Manaus. 1863 
CROCKER, W. H. \& CROCKER, J. - The Canela: Kinship, Ritual, and Sex in an Amazonian Tribe. Belmont: Wadsworth/Thompson Learning, 2004.

CUNHA, E. da - Amazônia Um paraíso perdido. Manaus: EDUA, 2003.

DAL POZ, J. \& SILVA, M. F. - MaqPar: A Homemade Tool for the Study of Kinship Networks. VIBRANT. Vol. 6 (2), 2008.

- Informatizando o Método Genealógico: um guia de referência para a Máquina de Parentesco. Teoria e Cultura, v.3, 2010.

DAL POZ, J. - Homens, animais e inimigos: simetrias entre mito e rito nos Cinta Larga. Revista de Antropologia, v.36, 1993.

DA MATTA, R. \& SEEGER, A. \& VIVEIROS DE CASTRO, E. - A construção da pessoa nas sociedades indígenas brasileiras. Boletim do Museu Nacional 32, 1979.

DERICKX, J. \& TRASFERETTI, J. A. - No Coração da Amazônia. Juruá, o rio que chora. Petrópolis: Vozes, 1992.

DESCOLA, P. - Beyond nature and culture Forms of attachment. HAU: Journal of Ethnographic Theory 2 (1), 2012.

DIENST, S. - The internal classification of the Arawan languages. LIAMES: Línguas Indígenas Americanas. Unicamp: 2008.

DREYFUS, S. - Systèmes dravidiens à filiation cognatique en Amazonie. L' Homme 126-128, 1993.

DUARTE DO PATEO, R. - Niyayu: relações de antagonismo e aliança entre os Yanomami da Serra das Surucucus (RR). São Paulo: FFLCH-USP, 2005. (Tese de Doutorado)

DUMONMT, Louis - Affinity as a Value. Chicago: University of Chicago Press, 1983.

DURKHEIM, É - As Formas Elementares da Vida Religiosa: O sistema totêmico na Austrália. Martins Fontes, São Paulo, 1996 [1912]. - Da Divisão do Trabalho Social. Martins Fontes, São Paulo, 2008 [1893].

EHRENREICH, P. - Contribuições para a etnologia do Brasil. Revista do Museu Paulista, N.S. II, 1948. 
EVANS-PRITCHARD, E. - Os Nuer - Uma descrição do modo de subsistência e das instituições políticas de um povo nilota. São Paulo: Editora Perspectiva, 1999[1940].

FANZERES, A. (ed.) - Ibure'i Hanuhanu Ikanade Shunu Deni Ihadekha: Plano de Gestão Territorial Terra Indígenas Deni. OPAN: s. 1., s.d.

FAUSTO, C. - Banquete de gente: comensalidade e canibalismo na Amazônia. Mana 8(2), 2002. - Donos Demais: maestria e domínio na Amazônia. Mana 14(2),

2008.

FERRARINI, S. A. - Tapauá: suas histórias, sua gente. Manaus: Ed. Umberto Calderaro, 1980. - Rio Purus. História - Cultura - Ecologia. São Paulo: FTD, 2009.

FLORIDO, Marcelo Pedro - As Parentológicas Arawá e Arawak: Um estudo sobre parentesco e aliança. São Paulo: FFLCH-USP, 2008. (Dissertação de Mestrado) - Aspectos do Parentesco Arawá. In: G. M. dos SANTOS (org.) - Álbum Purus. Manaus: EDUA, 2011. - O manakuni dos Deni: prestações e contraprestações no rio Cuniuá (AM) In: M. AMOROSO \& G. M. dos SANTOS (orgs.) - Paisagens, Circuitos e Lugares na Amazônia. São Paulo: PROCAD/CAPES; PPGAS e CESTA/USP; PPGAS e NEAI/UFAM; Terceiro Nome, 2013.

FORTES, M. - The Web of Kinship among the Tallensi. Oxford University Press, Londres, 1949

FRANCHETTO, B. - Forma e significado na poética oral Kuikuro. Amerindia 14, 1989. - A Celebração da História Nos Discursos Cerimoniais Kuikuro (Alto-Xingu). In: Eduardo Viveiros de Castro \& Manuela Carneiro da Cunha. (Orgs) Amazônia: etnologia e história indígena. São Paulo: NHII/USP, FAPESP, 1993. - As Artes da Palavra. Cadernos de Educação Escolar Indígena, v2 (1). Barra do Bugres: UNEMAT, 2003.

GALLOIS, D. T. - Mairi Revisitada: A Reintegração da Fortaleza de Macapá Na Tradição Oral dos Waiapi. São Paulo: NHII/USP, 1994.

GEBHART-SAYER, A. - Una Terapia Estética: Los Diseños Visionarios del Ayahuasca entre los Shipibo-Conibo. América Indígena, XLVI, 1986. 
GELL, A. - Art and Agency: An Anthropological Theory. Oxford: Clarendon Press, 1998.

GODELIER, M., T. R. \& TRAUTMANN \& F. E. TJON SIR FAT (eds.). Transformations of Kinship. Washington and London, Smithsonian Institution Press, 1998.

GONÇALVES, L. - O Amazonas: Esboço Histórico, Chorographico e Estatístico até o ano de 1903. Nova York: Hugo F. Hanf, 1904.

GONÇALVES, M. A. - O Significado do Nome. Cosmologia e Sociedade Pirahã. Rio de Janeiro: Sette Letras, 1993.

GORDON, F. - Os Kulina do Sudoeste Amazônico: História e Socialidade. Rio de Janeiro: UFRJ-Museu Nacional, 2006. (Dissertação de Mestrado)

GOW, P. - Of mixed blood: kinship and history in Peruvian Amazonia. Oxford: Clarendon Press, 1991.

- O parentesco como consciência humana: o caso dos Piro. Mana. Estudos de Antropologia Social 3(2), 1997.

2001.

- An Amazonian Myth and its History. Oxford: Oxford University Press,

GREGORY, C.A. - Gifts and commodities. London: Academic Press, 1982.

HAMBERGER, K. \& HOUSEMAN, M. \& GRANGE, C. - La parenté radiographiée: un nouveau logiciel pour le traitement et l'analyse des structures matrimoniales. L'Homme 191, 2009.

HÉRITIER, F. - L'exercice de la parenté. Paris: Gallimard, 1981.

- Parentesco. In: Enciclopédia Einaudi. Volume 20 Parentesco. Porto, Imprensa Nacional - Casa da Moeda, 1989.

HOUSEMAN, M. \& WHITE, D. - Taking Sides: Marriage Networks and Dravidian Kinship in Lowland South America. In: GODELIER, M. \& TRAUTMANN, T. \& TJON SIE FAT, F. (Eds.) Transformations of Kinship. Washington: Smithsonian Institution Press, 1998.

HOWARD, C. V. - A Domesticação das Mercadorias: Estratégias Waiwai. In: ALBERT, B. \& RAMOS, A. R. (orgs.) - Pacificando o Branco. Cosmologias do contato no Norte-Amazônico. Editora UNESP, São Paulo, 2002.

HYMES, D. - In Vain I Tried to Tell You: Essays in Native American Ethnopoetics. Philadelphia: University of Pennsylvania Press, 1981. 
JARAMILLO, Heliodoro - Breve Notícia sobre os Valles dos Rios Purús e Madeira Afluentes do Amazonas (1903). Manaus: Edições Governo do Estado do Amazonas / Secretaria de Estado da Cultura, 2004.

JARDIM, C. S. - Os Zuruahã. Socialidade e escatologia. Rio de Janeiro: UFRJMuseu Nacional, 2009. (Dissertação de Mestrado)

JOLLY, É. - Récits dogon au passe recomposé. Ethnologies Comparées, 5, 2002.

KOOP, G. \& KOOP, L. - Dicionário Deni-Português. Versão Online. Anápolis: SIL Brasil, 1985.

KOOP, G. \& LINGENFELTER, S. G. - Os Dení do Brasil Ocidental: um estudo de organização sócio-política e desenvolvimento comunitário. Dallas: Museu Internacional de Cultura, 1983.

KROEMER, G. - Cuxiuara: o Purus dos indígenas. São Paulo: Edições Loyola, 1985. - Kunahã Made: O Povo do veneno. Belém: Edições Mensageiro, 1994.

(Relatório)

- Relatório de Viagem aos Índios Dení. Manaus: CIMI, 1995. - Os Deni. Contato e Cultura: uma perspectiva antropológica do manejo de recursos renováveis e de um projeto econômico. Manaus: Universidade do Amazonas, 1997. (Monografia)

LAZARIN, M. A. - A Descida do Rio Purus: uma experiência de contato interétnico. Brasília, 1981 (Dissertação de Mestrado).

LÉVI-STRAUSS - Guerra e comércio entre os índios da América do Sul. In: Egon Schaden (org.) - Leituras de etnologia brasileira. São Paulo: Companhia Editora Nacional, 1976 [1942].

- As Estruturas Elementares do Parentesco. Petrópolis: Vozes, 1982 [1949].

- História de Lince. São Paulo: Companhia das Letras, 1993.

- O Cru e o Cozido. Mitológicas 1. São Paulo: Cosac Naify, 2004

[1964]. - A análise estrutural em linguística e antropologia. In: Antropologia Estrutural. Rio de Janeiro, Tempo Brasileiro, 1996 [1945].

LIMA, T. S. - Um peixe olhou para mim: o povo Yudjá e a perspectiva. São Paulo, Ed. Unesp/ISA/NUTI, 2005. 
LOLLI, P. A. - O continuo e o descontinuo em Lévi-Strauss. Campinas: Unicamp, 2005. (Dissertação de Mestrado)

LORRAIN, C. - Making Ancestors: The Symbolism, Economics and Politics of Gender among the Kulina of Southwest Amazonia (Brazil). King's College University of Cambridge, 1994. (Tese de Doutorado).

MAIZZA, F. - Cosmografia de um Mundo Perigoso: Espaço e relações de afinidade entre os Jarawara da Amazônia. São Paulo: Nakin-Edusp, 2012.

MELATTI, J. C. - O Sistema Social Krahô. FFLCH-USP, São Paulo, 1970. (Tese de Doutorado).

MENDONÇA, B. - Reconhecimento do Rio Juruá (1905). Belo Horizonte: Itatiaia; Acre: Fundação Cultural do Acre, 1989.

MORGAN, L. - Systems of Consanguinity and Affinity of the Human Family. Lincoln: University of Nebraska Press, 1997. [1871]

NEEDHAM, R. - Prescription. Oceania 43, 1973.

NOOY, W. \& MARVAR, A. \& BATAGELJ, V. - Exploratory Social Network Analysis with Pajek. New York: Cambridge University Press, 2011

OVERING, J. \& PASSES, A. - Introduction: Conviviality and the opening up of Amazonian anthropology. In: \& (eds.) - The anthropology of love and anger: The aesthetics of conviviality in native Amazonia. London: Routledge, 2000.

PASTORE JR, F. \& BORGES, V-L - Extração Florestal Não-Madeireira na Amazônia: Armazenamento e Comercialização. ITTO - FUNATURA - IBAMA LATEQ-UnB, s.d.

PEZZUTI, J. \& CHAVES, R. P. - Etnografia e manejo de recursos naturais pelos índios Deni, Amazonas, Brasil. Acta Amazônica, v 39 (1), 2009.

POLLOCK, D. - Looking for a sister. Culina siblingship and affinity. In: J. SHAPIRO - The Sibling Relationship in Lowland South American. Working Papers on South American Indians n.7. Bennington: Bennington College, 1984. - Personhood and illness among the Culina of Western Brazil. New York: The University of Rochester, 1985a. (Tese de doutorado) - Food and Sexual Identity Among the Culina. Food \& Foodways, vol 1(1), $1985 b$.

- Death and Afterdeath among the Kulina. The Latin American Anthropology Review 5(2), 1993. 
- Partible Paternity and Multiple Maternity among the Kulina. In: S.

BECKRMAN \& P. VALENTINE (eds) - Cultures of Multiple Fathers: Partible Paternity in Lowland South America University of Florida Press, 2002.

- Siblings and Sorcerers: Shamanism and the Paradox of Kinship

among the Kulina. In: N. WHITEHEAD \& R. WRIGHT (eds) - In Darkness and Secrecy: The Anthropology of Assault Sorcery and Witchcraft in Amazonia. Duke

PORTA, E. \& FANK, J. - A vida social e econômica dos Sorowaha. Cuiabá: OPAN/CIMI, 1996.

RADCLIFFE-BROWN, A. - Introduction. In: \& FORDE, D. (Ed.). African System of Kinship and marriage. London: Oxford University Press, 1967 [1950]. - The Study of Kinship Systems. [1941] In: TURNER, B. S.

(ed.) The Early Sociology of the Family, vol 1. London: Routledge/Thoemmes Press, 1998.

RANGEL, L. H. V. - Os Jamamadi e as armadilhas do tempo histórico. Tese de Doutorado. São Paulo, PUC-SP, 1994. (Tese de Doutorado).

RIBEIRO, D. - Os índios e a civilização. Rio de Janeiro: Editora Vozes, 1993.

RIVERS, W. H. R. - The Genealogical Method of Anthropology Inquiry. Sociological Review 3, 1910.

RIVET, P. \& TASTEVIN, C. - Les langues arawak du Purús et du Juruá (Groupe Arauá). Journal de la Societé des Américanistes, Tomes XXX (1), 1938.

RIVIÈRE, P. - O Indivíduo e a Sociedade na Guiana: Um Estudo Comparativo da Organização Social Ameríndia. São Paulo: Edusp, 2001 [1984].

RODRIGUES, C. S. - A Paisagem Etnográfica do Médio Purus/Juruá. Manaus: PPGAS-UFAM, 2010. (Dissertação de mestrado)

- Organização Social Jamamadi, Kulina e Deni no Complexo

Médio Jruá/Purus. In: G. M. dos SANTOS (org.) - Álbum Purus. Manaus: EDUA, 2011.

SÁEZ, O. C. - A Terceira Margem da História: estrutura e relato das sociedades indígenas. Revista Brasileira de Ciências Sociais, v. 20 n.57, 2005.

- O nome e o tempo dos Yaminawa. São Paulo: Editora da UNESP, 2006.

SAHLINS, M. - $O$ 'pessimismo sentimental' e a experiência etnográfica: por que a cultura não é um 'objeto' em vias de extinção (parte I). In: Mana, v. 3, n. 1. Rio de Janeiro: UFRJ, 1997. 
- Ilhas de História. Rio de Janeiro: Jorge Zahar, 2003 [1985].

SALZER, M. \& CHAPMAN, S. - Dicionário Bilíngue nas línguas Paumari e Portuguesa. Porto Velho: Sociedade Internacional de Lingüística, 1998.

SANTOS-GRANERO, F. - The Arawakan Matrix: Ethos, Language, and History in Native South America. In: HILL, J. H. \& SANTOS-GRANERO, F. (eds.) Comparative Arawakan Histories: Rethinking Language Family and Culture Area in Amazonia. Urbana: University of Illinois Press, 2002.

SASS, W. (org.) - Ima Bute Denikha. Mitos Deni. São Leopoldo: OIKOS-COMIN, 2004.

SCHNEIDER, D. M. - American Kinship: A Cultural Account. Second Edition.

Chicago and London: The University of Chicago Press, 1980. - A Critique of the Study of Kinship. Ann Arbor: The

University of Michigan Press, 1984.

SHAPIRO, J. R. - Marriage Rules, Marriage Exchange, and the Definition of Marriage in Lowland South American Societies. In: KESINGER, K. M. (ed.) Marriage Practices in Lowland South America. Urbana and Chicago: University of Illinois Press, 1984.

SIGRIST, T. - Guia de Campo. Aves da Amazônia Brasileira. Avis Brasilis, 2008.

SILVA KANAÚ, A. O. - Madijadenicca Ima. Histórias dos Kulina. SCP-CIMI-/AO, 1983.

SILVA, A. O. \& MONSERRAT, R. M. F. - Dicionário Kulína-Português e Português-Kulína (dialeto do igarapé do Anjo). Acre: CIMI, 1984.

SILVA, D. A. B. - Música e pessoalidade: por uma antropologia da música entre os Kulina do Alto Purus. Florianópolis: UFSC, 1997. (dissertação)

SILVA, M. F. - Parentesco e Organização Social na Amazônia: um rápido esboço. Anuário de Estudios Amerindios v. 61 (2), Sevilla, 2004. - Romance de Primas e Primos: uma Etnografia do parentesco Waimiri - Atroari. Manaus: EDUA, 2009. - Liga dos Enawene-Nawe: um estudo da aliança de casamento na Amazônia Meridional. São Paulp: USP, 2012. (Livre docência)

STADEN, H. - Duas Viagens ao Brasil. São Paulo, Ed. Itatiaia: 1974.

STEERE, Joseph Bael - Tribos do Purus. Sociologia 11(2), São Paulo, 1949. 
STRATHERN, M. - O gênero da dádiva: problemas com as mulheres e problemas com a sociedade na Melanésia. Campinas: Editora da Unicamp, 2009[1988]. - Kinship, Law and the Unexpected. Relatives Are Always a Surprise. New York: Cambridge University Press: 2005.

TASTEVIN, C. - Quelques considérations sur les indiens du Juruá. Bulletin de la Societé d'Anthropologie de Paris, Paris : Societé d'Anthropologie, ser.6, n. 10, 1919. - Les études ethnographiques et linguistiques du P. Tastevin en Amazonie. Journal de la Société des américanistes, v.16, n.16, 1924.

TAYLOR, A.-C. - L'oubli des morts et la mémoire des meurtres. Expérienes del'histoire chez les Jíbaro. Terrain. Carnets du Patrimoine Ethnologique 29, 1997.

TEIXEIRA PINTO, M. - História e cosmologia de um contato. A atração dos Arara. In: ALBERT, B. \& RAMOS, A. R. (orgs.) - Pacificando o Branco. Cosmologias do contato no Norte-Amazônico. Editora UNESP, São Paulo, 2002.

TOWNSEND, P. K. \& ADAMS, P. J. - From wives to peccaries: marriage conflict among the Culina. Communication presented at the 72nd Annual Meeting of the American Anthropological Association - Symposium on Marriage in Lowland South America. New Orleans, 1978

TRAUTMANN, T. R. - Dravidian Kinship. Cambridge: Cambridge University Press, 1981.

VANSINA, J. - Oral tradition as history. Madison: The University of Wisconsin Press, 1985.

VIDAL, L. - Grafismo Indígena: estudos de antropologia estética. São Paulo: EDUSP, 1992.

VILAÇA, A. - Making kin out of others $n$ Amazonia. The Journal of the Royal Anthropological Institute 8 (2), 2002.

VIVEIROS DE CASTRO, E. B. - Os Kulina do Alto Purus : relatório de viagem realizada em janeiro-fevereiro de 1978. Rio de Janeiro, 1978.

- Araweté: os deuses canibais. Rio de Janeiro:

Jorge Zahar, 1986.

- Princípios e Parâmetros: um comentário a

L'Exercice de la parenté. Comunicação do PPGAS no. 17. Museu Nacional - UFRJ, Rio de Janeiro, 1990. 
- Alguns aspectos da afinidade no dravidianato

amazônico. In:

\& CARNEIRO DA CUNHA, M (orgs.) - Amazônia: etnologia e história indígena. São Paulo: EDUSP/NHII, 1993.

- Ambos os três: sobre algumas distinções

tipológicas e seu significado estrutural na teoria do parentesco. Anuário Antropológico 95. Rio de Janeiro, 1996.

- Dravidian and Related Kinship Systems In:

GODELIER, M. \& TRAUTMANN, T. R. \& TJON SIE FAT, F.(Eds.) Transformations of Kinship. Washington, Smithsonian Institution Press, 1998. - A Inconstância da Alma Selvagem. São Paulo,

Cosac \& Naify, 2002.

- The gift and the given: three nano-essays on

kinship and magic. In: S. BAMFORD \& J. LEACH (Org.) - Kinship and beyond: the genealogical model reconsidered. Oxford: Berghahn Books, 2009.

VOGEL, A. - Dicionário Jarawara - Português. Cuiabá: SIL, 2006.

WAGNER, R. - Are There Social Groups in the New Guinea Highlands? In: LEAF, M. J. (ed.). Frontiers of Anthropology: An Introduction to Anthropological Thinking. New York: D. Van Nostrand Company, 1974.

WEBER, Teresinha - O Rio Purus e os Interesses Econômicos da Província- A fala dos presidentes. UFAM, 1998. (Monografia História). 